\title{
Archaeological Testing of the Burleson Homestead at 41HY37 Hays County, Texas
}

C. Britt Bousman

Department of Anthropology, Texas State University

David L. Nickels

Follow this and additional works at: https://scholarworks.sfasu.edu/ita

Part of the American Material Culture Commons, Archaeological Anthropology Commons, Environmental Studies Commons, Other American Studies Commons, Other Arts and Humanities Commons, Other History of Art, Architecture, and Archaeology Commons, and the United States History Commons

Tell us how this article helped you.

This Article is brought to you for free and open access by the Center for Regional Heritage Research at SFA ScholarWorks. It has been accepted for inclusion in Index of Texas Archaeology: Open Access Gray Literature from the Lone Star State by an authorized editor of SFA ScholarWorks. For more information, please contact cdsscholarworks@sfasu.edu. 


\section{Archaeological Testing of the Burleson Homestead at 41HY37 Hays County,}

Texas

\section{Creative Commons License}

(c) (1) (8)

This work is licensed under a Creative Commons Attribution-NonCommercial 4.0 International License 


\title{
Archaeological Testing of the Burleson Homestead at $41 \mathrm{HY37}$ Hays County, Texas
}

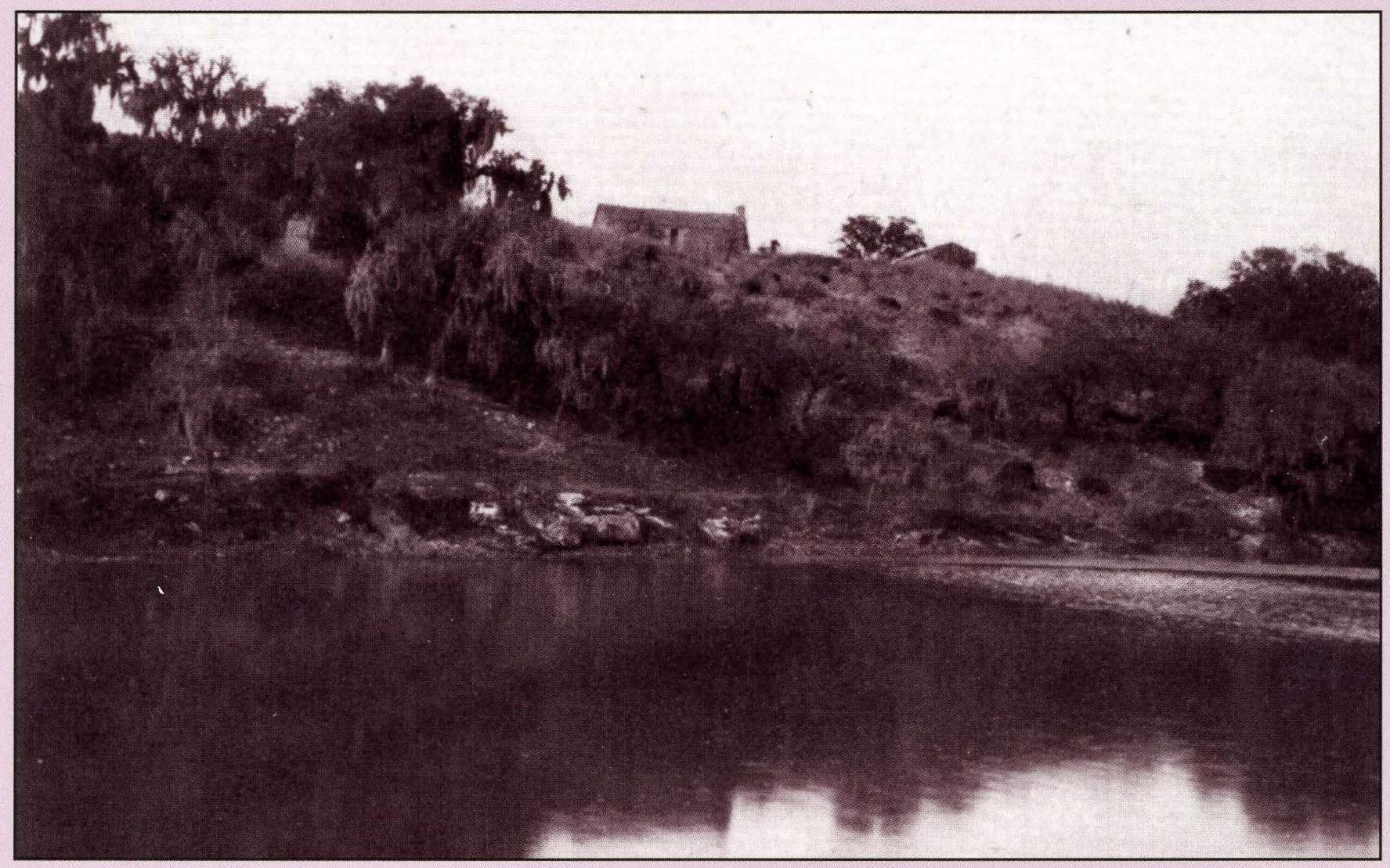

\section{Assembled by \\ C. Britt Bousman and David L. Nickels}

\author{
With contributions by \\ C. Britt Bousman, David L. Nickels, Kevin Schubert, \\ Barbara Meissner, Isabel Gutierrez, Sr., and Vergie Richardson
}

Archaeological Studies Report No. 4

Center for Archaeological Studies

Texas State University-San Marcos 


\title{
Archaeological Testing of the Burleson Homestead at 41HY37 \\ Hays County, Texas
}

\author{
Assembled by \\ C. Britt Bousman and David L. Nickels \\ With Contributions by \\ C. Britt Bousman \\ David L. Nickels \\ Kevin Schubert \\ Barbara Meissner \\ Isabel Gutierrez, Sr. \\ and Vergie Richardson \\ Principal Investigator: C. Britt Bousman \\ Texas Antiquities Committee Permit No. 2406
}

Archaeological Studies Report No. 4

Center for Archaeological Studies

Texas State University-San Marcos

2003 
The following information is provided in accordance with the General Rules of Practice and Procedure, Chapter 41.11 (Investigative Reports), Texas Antiquities Committee:

1. Type of Investigation: Archival Research and Archaeological Testing

2. Project Name: Archaeological Testing of the Burleson Homestead at $41 \mathrm{HY} 37$

3. County: Hays

4. Principal Investigator: C. Britt Bousman

5. Name and Location of Sponsoring Agency: Southwest Texas State University (now Texas State University-San Marcos) with a Matching Grant from the Texas Historical Commission

6. Texas Antiquities Committee Permit Number: 2406

7. Published by: The Center for Archaeological Studies, Texas State University-San Marcos, 601University Drive, San Marcos, Texas 78666

Copyright ${ }^{\circledR} 2003$ by Center for Archaeological Studies at Texas State University-San Marcos All rights reserved.

No part of this book may be reproduced or utilized in any form or by any means, electronic or mechanical, including photocopying, recording, or by any information storage and retrieval system without permission in writing.

For further information on this and other publications please contact:

\author{
Center for Archaeological Studies \\ Texas State University-San Marcos \\ 601 University Drive, San Marcos, Texas 78666 \\ www.txstate.edu/anthropology/cas/
}

Editor: Connie Thompson Gibson

Cover Illustration: Photograph taken in 1907 showing the San Marcos River, the Burleson home, and an outbuilding. (Photo reproduced from the San Marcos-Hays County Collection at the San Marcos Public Library).

Printed in the United States of America 


\begin{abstract}
At the request of Southwest Texas State University (now Texas State University-San Marcos), the Center for Archaeological Studies (CAS) conducted an archaeological excavation of the historic Burleson Homestead (41HY37). The excavation was conducted in June and July of 2000 under Texas Antiquities Committee Permit No. 2406. Artifacts collected during the project were processed and curated at CAS. In addition, CAS conducted archival research on structures located within the project boundaries. Upon completion of the excavation and archival research, a great deal has been learned concerning the Burleson ownership and use of the San Marcos Springs. Unfortunately, little intact evidence survives. CAS determined that the original cabin had been completely dismantled and a replica cabin was assembled nearby, but not on the original foundation. Most of the deposits on the ridge top have been disturbed and most of the recorded features relate to the construction of the replica cabin in the 1960s. The one early feature that does survive, Feature 4, should be preserved and used to provide a more accurate and full understanding of the locale when Edward Burleson settled the site and helped establish the community of San Marcos. CAS therefore recommends that no further archaeological investigations are necessary and that the site should be used to further the public education of the early history of the San Marcos Springs and the City of San Marcos.
\end{abstract}




\section{Table of Contents}

Abstract iii

Table of Contents .. v

List of Figures vii

List of Tables $\mathrm{x}$

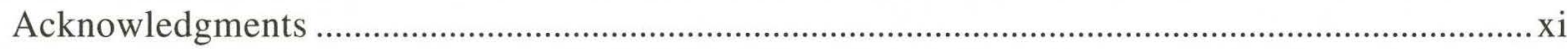

Chapter 1. Introduction 1

Chapter 2. Prehistoric and Historic Background of San Marcos Springs and the Burleson Homestead .5

Chapter 3. Goals and Methods 33

Chapter 4. Results of the Archaeological Investigations

Chapter 5. Summary and Recommendations 89

References Cited

Appendix A. Bottle Glass 105

Appendix B. Window Glass Thickness

Appendix C. Ceramics

Appendix D. Nails, Bolts, and Screws

Appendix E. Metal Items

Appendix F. Miscellaneous Items and Samples

Appendix G. Chipped Stone

Appendix H. Occurrences of Time Period Diagnostics (Mixing of Artifacts)

Appendix I. Fauna

Appendix J. Transcript of Audiotape Interview with Isabel Gutierrez, Sr.

Appendix K. Reminiscence by Mrs. Vergie Richardson 


\section{Table of Contents (Continued)}

Appendix L. Record of Deed Transactions for the Mill Tract

Appendix M. Record of Deed Transactions for the Old Burleson Homestead ........................... 183

Appendix N. Possessions of General Edward Burleson at Death ............................................... 185 


\section{List of Figures}

1-1. Map of the San Marcos area showing location of the Burleson Homestead. Inset:

Hays County, Texas.

2-1. 1840 deed for purchase of 640-acre tract by Nathaniel Lewis from Maria Josepha

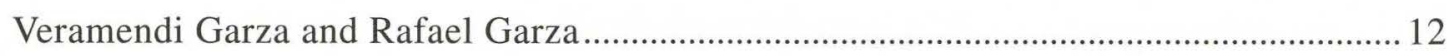

2-2. Portrait of General Edward Burleson .................................................................................. 14

2-3. The early brands registered to General Edward Burleson ............................................... 19

2-4. 1855 map of San Marcos Springs showing the Homestead Tract, Mrs. Burleson's Residence Tract, the Mill Tract, and the City of San Marcos area .....................................2 21

2-5. Augusta Koch's bird's-eye view map of the San Marcos area ........................................... 23

2-6. The Burleson cabin is shown on the crest of the ridge (date unknown) ........................... 25

2-7. Photograph taken in 1907 showing Burleson's house and an outbuilding .......................25

2-8. Postcard with a 1908 postmark, showing the old Burleson cabin ....................................26

2-9. Photograph dated March 12, 1911 illustrating the enclosed porch on the northwest side of the old Burleson cabin

2-10. The north and east sides of the Burleson cabin, showing the original chimney before its collapse

2-11. The Burleson cabin's east side, showing the enclosed dogtrot

2-12. Photograph of the Burleson cabin in ruins, published in the April 11, 1915 San Antonio Express

2-13. The Daughters of the Republic of Texas erected a granite marker at the site of the Burleson cabin in 1932

2-14. A Sky Ride gondola station was erected on the original cabin site in 1960

2-15. Logs were used from structures contemporaneous with the Burleson cabin, such as the Stringtown Stagecoach Stop, in construction of the replica cabin

2-16. The Burleson cabin replica, constructed in 1966 ........................................................... 31

3-1. Project site map showing Burleson replica cabin and gondola station ............................ 35

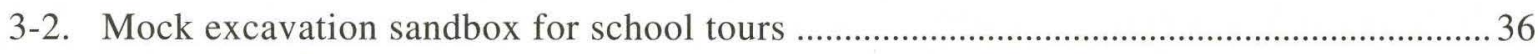

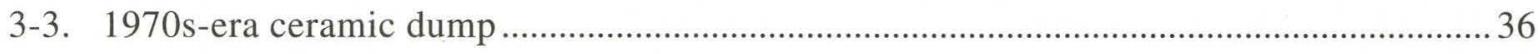

3-4. Project site map showing cabin replica and locations of excavation units and trenches 37

3-5. Photograph of Units 1, 6, and 8, with members of the Burleson family during a site tour (Photograph compliments of Ron Coley). 


\section{List of Figures (CONTinued)}

3-6. Photograph of Units 9, 12, 15, 17, 19, 22, 24, 26, and 28 at Feature 4 with members of the Burleson family during a site tour (Photograph compliments of Ron Coley) ........ 38

3-7. Photograph of Units 7, 2, and 5, with members of the Burleson family during a site tour (Photograph compliments of Ron Coley).

3-8. Photograph of Units 4 and 10, with members of the Burleson family during a site tour (Photograph compliments of Ron Coley)

3-9. Units 16, 25, 27, and 29, with student crew (Photograph compliments of Ron Coley) .. 40

3-10. Units 23 and 30 with student crew. Unit 3 in background at cabin corner (Photograph compliments of Ron Coley)

4-1. Feature 1, firecracked rock and midden debris in Trenches 1A and 1B .........................4 42

4-2. Naturally fragmented bedrock designated Feature 2 ................................................... 43

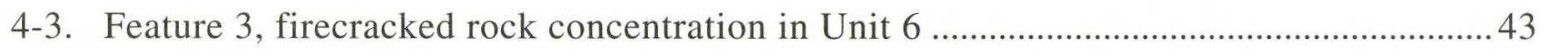

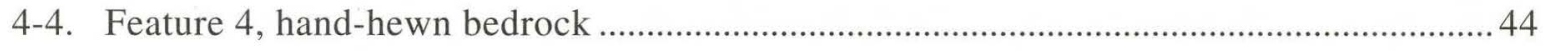

4-5. Feature 5, firecracked rock concentration in Units 11, 13, and 14 ............................... 45

4-6. Features 6 and 7, concrete mixing area on fractured bedrock .......................................46

4-7. Panoramic view of western spillway and dam. Note abandoned spillway immediately to the right of three trees in the center of photograph ........................................................... 47

4-8. Abandoned spillway in center of dam .................................................................................. 47

4-9. Cement caps covering dam. White sandbags placed on most recent cap and three other caps visible to the right of white sandbags ............................................................................. 47

4-10. Cement cap at western spillway. Cement covers log cribs ................................................ 48

4-11. Inscribed date of $2 / 14 / 91$ on most recent cap near western spillway .................................. 48

4-12. Inscribed date of Dec. 2, 1909 on eastern spillway ........................................................ 49

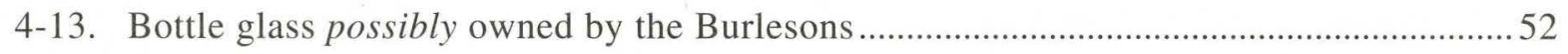

4-14. Unique bottle glass, but not associated with the Burleson occupation ............................55

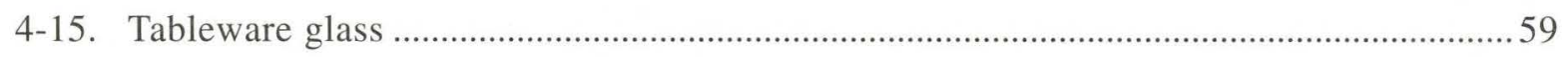

4-16. Dinnerware ceramics probably associated with the Burleson occupation ........................63

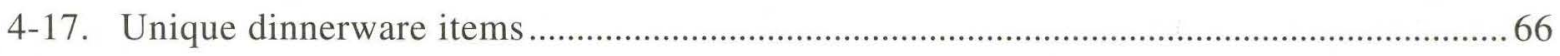

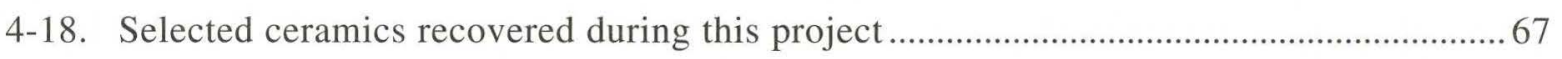

4-19. Selected stoneware sherds: (a) Albany slip; (b) alkaline glaze; (c) Bristol glaze ............ 69

4-20. Porcelain doll leg, possibly belonging to the Burlesons, Unit 25, Level 1 .......................69 


\section{List OF Figures (CONTINUEd)}

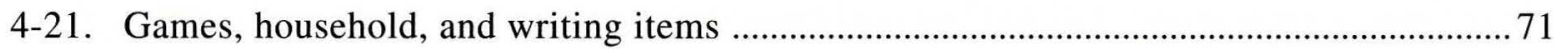

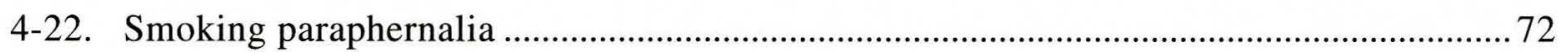

4-23. Military button found in Unit 15, Level 1 ....................................................................... 75

4-24. Brass slide buckle or clasp, with a U. S. design date of 1841 .......................................... 75

4-25. Buttons that could be from the Burleson occupation ....................................................... 76

4-26. Buttons and snaps that post-date the Burleson occupation …............................................. 77

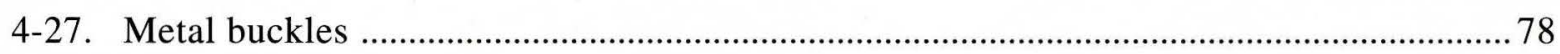

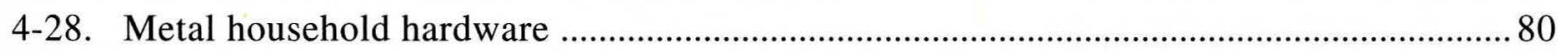

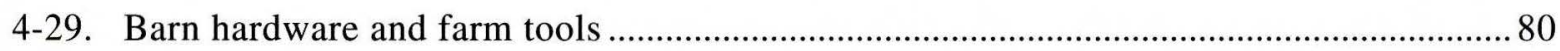

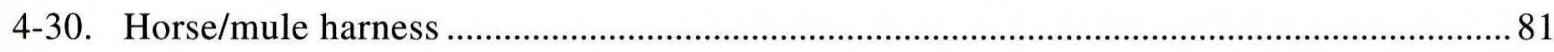

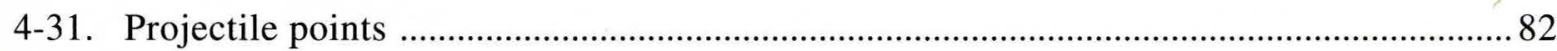

5-1. Water well, although reconstructed inaccurately, provides additional historic context for the site 


\section{List OF TABLES}

4-1. Features encountered during the excavations .41

4-2. Probable ages of the tableware ceramic assemblage at $41 \mathrm{HY} 37$ 63

4-3. Buttons, buckles, and snaps .73

4-4. Non-military buttons that could date to the Burlesons' occupation of the site .75

4-5. Selected unique metal items .79

4-6. Contingency table comparison of data from two open campsites .83

4-7. Taxon list of faunal materials recovered at the Burleson Homestead .85

4-8. Contingency table of results of diagnostics distributed horizontally across the site 86

5-1. Artifacts that probably date to the mid-nineteenth century, grouped by gross functional categories 90 


\section{ACKnowledgments}

The authors have many colleagues and professional staff to thank for the content and quality of this publication. All took a personal interest in telling the story of General Burleson and his homestead in San Marcos. Notably, Michael Abbott of Texas State University-San Marcos wholeheartedly supported the endeavor both financially and operationally. Ron Coley from Aquarena Center and his entire staff were always extremely helpful, and as you can see in this publication, Ron is a great photographer who visited with us often. Professionals from both the Alkek Library and the San Marcos Public Library helped us locate and wade through many rare and important documents, some of which they have generously allowed us to reproduce here, and we are especially indebted to Stephanie Langerkamp and Ben Pensiero. John Anderson, Preservation Officer at the Texas State Library and Archives in Austin, assisted CAS in obtaining a copy of the only known original portrait of Edward Burleson. Colleagues Anne Fox, Dee Ann Story, and David Toomey examined artifacts, and otherwise provided thought-provoking insight as to how to best examine the archaeological evidence.

The digging and sifting of dirt around the Burleson Cabin in hot weather was conducted by Katherine Brown and students from Southwest Texas State University. Artifacts were washed and sorted in the lab by Shawn Soucie, and ably curated to last for many years by Connie Gibson and Cody Davis. Illustrations in this report were either designed or put into the proper format by Ray Umsheid, and finally Connie spent many hours editing and preparing for final print what we believe is an interesting and informative contribution to Texas archaeology and history. 


\section{Chapter 1}

\section{Introduction}

\section{Britt Bousman}

In 1848, Edward Burleson constructed a log cabin on a ridge overlooking the San Marcos Springs. Since the time Burleson made his home above the springs, this bucolic setting has been transformed, first into a major tourism facility, and now it is part of a university campus. But still, evidence of this earlier life and the historic events remain preserved in the soil draping the escarpment that stands watch over the everflowing San Marcos Springs. This hillside proves witness to many of the significant historic events that shaped the development of Texas, Hays County, and the City of San Marcos. The following report provides some of the unique evidence for these historical events.

In the spring of 2000, Dr. Michael Abbott, Special Assistant to the President at Southwest Texas State University (SWT), requested that the Center for Archaeological Studies (CAS) conduct a study of the original Edward Burleson Homestead at the springs. In the following summer, the Department of Anthropology's field school, under the direction of Katherine Brown, excavated the site with the express objectives of determining if the original site still contained intact archaeological deposits, if the replica constructed in the 1960s was placed on the original site and foundation, and if the information provided by the excavation could be used for the accurate representation and interpretation of this site.

\section{Environmental Setting}

Edward Burleson built his house on a high promontory perched 100 feet above the rolling Blackland Prairie and the San Marcos Springs (Figure 1-1). This feature is an escarpment, known as the Balcones Escarpment, and it is now covered with a dense growth of mountain juniper and live oak. At the base of the escarpment are hundreds of small and large artesian springs known collectively as the San Marcos Springs, now flooded by Spring Lake. The remarkable clear water that issues from the springs feeds Spring Lake, formed when Edward Burleson first built a dam in 1849 to dam the San Marcos River. To the east beyond the springs is Sink Creek, a small tributary of the San Marcos River that now forms an arm of Spring Lake. At a greater distance, beyond the now-flooded Sink Creek, are the gently rolling grasslands known as the Blackland Prairie. The cabin captured a commanding view of the spring and surrounding landscape. Even in the summer, a cool breeze blows from the east off the Blackland Prairie. This unique and spectacular setting was created by a series of geological processes and events. 


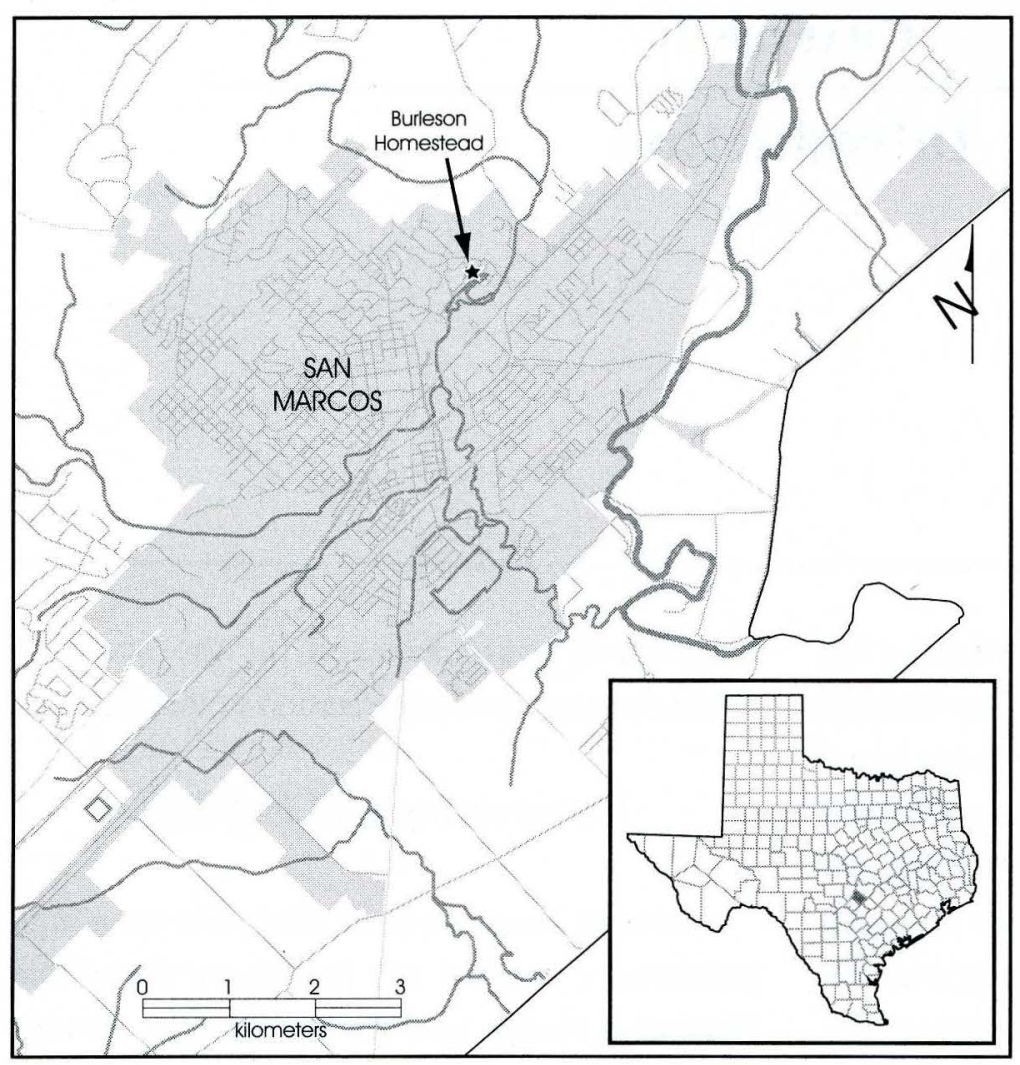

Figure 1-1. Map of the San Marcos area showing location of the Burleson Homestead. Inset: Hays County, Texas.
The Lower Cretaceous formations are found to the north and west of the Balcones Escarpment and the Upper Cretaceous formations are generally to the east and south of town. On the north and east sides of San Marcos, the Blanco River left extensive alluvial deposits during the Pleistocene and Holocene, and the San Marcos River itself has deposited deep alluvium during the terminal Pleistocene and early Holocene.

In the Miocene period, approximately 10 million years ago, the area underwent dramatic uplift and faulting. This process elevated the Cretaceous limestones some 2,000 feet above sea level, creating the Edwards Plateau, and it sheared or faulted

\section{Geology}

The oldest surface geological deposits on the project area are Lower Cretaceous limestones from the Edwards Formation (Barnes 1974; Ogden et al. 1986). These are overlaid by later Lower Cretaceous formations known as the Georgetown Formation, the Del Rio Clay, and the Buda Limestone Formation. Upper Cretaceous deposits are also found in the area. These include the Eagle Ford Group, Austin Chalk, and Pecan Gap. The Edwards Formation limestone occurs northwest of the Burleson Homestead site. Further downslope and near to the escarpment edge, Buda Limestone is exposed. Del Rio Clays form the upper slopes and the Georgetown formation is exposed on the lower slopes of the escarpment. the limestone deposits to create the Balcones Fault Zone (Barnes 1974). Running in a northeast to southwest direction, the San Marcos Springs Fault falls along the southern edge of Spring Lake (Ogden et al. 1986). To the northeast of Spring Lake, the Kyle Fault joins with the San Marcos Spring Fault. A third fault is between Aquarena Springs Drive and Sink Creek and runs parallel with Aquarena Springs Drive. Another unnamed fault is also roughly parallel, but on the southeast side of Bobcat Stadium. This fault zone forms a stair-stepped topography, part of which is now buried by alluvial deposits.

West of the Balcones Fault Zone, Lower Cretaceous formations are on the surface, and Upper Cretaceous formations dominate east of the 
fault zone. The Lower Cretaceous formations are much harder and more resistant to erosion, while the Upper Cretaceous formations are more friable and more easily eroded (Spearing 1991), thus the differential resistance to erosion has helped accentuate the escarpment. It is on this, one of the more prominent features of this stair-stepped topography, that Burleson chose to build his cabin.

A complex series of underground caverns and solution cavities have formed due to limestone dissolution in the Lower Cretaceous formations, especially the Edwards Formation. These caverns and solution cavities are filled with water and the Miocene faulting allows this water to reach the surface at a series of springs along the full length of the eastern and southern edge of the Balcones Fault Zone. The San Marcos Springs is one of these springs; others include Barton Springs in Austin, Comal Springs in New Braunfels, San Pedro Springs in San Antonio, and San Felipe Springs in Del Rio.

Since the Miocene faulting, a series of river systems cut valleys that now drain this region. In the San Marcos area, the most significant river is the Blanco River. It has cut a wide and deep valley that breaches the Balcones Fault Zone to drain the central Edwards Plateau. However, this was not the first valley system that drained this area. Between San Marcos and Kyle, north of the Blanco River, is a southeasterly-trending linear patch of alluvial deposits, known as the Leona Formation (Barnes 1974), and these document the existence of a river, perhaps an early stage of the Blanco River, that drained the Hill Country. Today the Leona Formation survives on interfluves and ridges, showing that a considerable amount of erosion has downgraded the landscape perhaps one hundred feet or more since a stream deposited those sediments.
A second important river is the San Marcos River. Unlike most rivers, this river has no real drainage basin because it emanates with a strong flow at the San Marcos Springs. The confluence of the San Marcos and Blanco Rivers is in the southeastern part of the City of San Marcos.

\section{Soils}

As bedrock and alluvial deposits are exposed to wind, rain, sun, and living organisms, through time soils begin to form. Soils are a weathering product and the nature of a soil is strongly influenced by the parent material as well as the climate, topography, and the plants and animals that live in and on the landscape. Soils are classified into different types based on their characteristics. These characteristics include the sediment textures (sand, silt, or clay), the thickness and the degree of soil horizon (A, B, and C) development, the presence of illuviated (down moving) materials such as calcium carbonate, and a variety of other factors (Birkeland 1974). In the area around Spring Lake four soil types have been identified and mapped.

On the crests and upper slopes of the Balcones Escarpment are soils known as Comfort-Rock Outcrop Complex. These are shallow, welldrained, upland, clayey and stony soils with an A-B-R profile. On the middle and lower slopes of the escarpment is the Eckrant-Rock Outcrop Complex (Erg). These are shallow, clayey soils on steep slopes with numerous areas where bedrock outcrops through the soil. Runoff is rapid on these soils. Typically these soils have a shallow A horizon that sits directly on limestone bedrock. The A horizon is dark brown or gray clay with abundant angular limestone and chert fragments. These soils will not support agriculture. 
In the floodplains are Tinn (Tn) soils. These are deep, poorly drained and frequently flooded, clayey soils found on level terraces and floodplains. Typical profiles have thick A and B horizons on a series of $\mathrm{C}$ horizons composed of alluvial sediments. Surfaces with Tinn soils were prized for farming, and historic records (see Chapter 2) indicate that Edward Burleson farmed the area between Sink Creek and the San Marcos Springs that was covered by Tinn soils.

Closer to the streams and rivers are Oakalla soils. These are deep, well-drained, loamy soils formed on alluvial sediments. Typical pedons consist of an Ap horizon, an A horizon, and a thick $\mathrm{B}$ horizon that sits on a very thick $\mathrm{C}$ horizon.

\section{Vegetation}

As distinctly as the topography, geology, and soils are patterned, so too is the vegetation. Diamond et al. (1987) map two distinct plant communities in the project area. These are the Balcones Canyonlands Woodlands and the Blackland Prairie. The Blackland Prairie is a tall grass community dominated by little bluestem (Schizachyrium scoparium) and other grasses, while the Balcones Canyonlands Woodlands are dominated by live oak (Quercus fusiformis) and ash juniper (Juniperus ashei). Along the stream banks are bald cypress (Taxodium distichum). The Balcones Canyonlands and the riverine settings were the primary source of timber, while the Blackland Prairie was used for agriculture and grazing.

\section{Fauna}

The Burleson Homestead area occurs at the boundary between the Balconian and Tamaulipan biotic provinces (Blair 1950). These are faunal regions. The area should have species from both provinces. These include white-tailed deer (Odocoileus virginianus), badger (Taxidea taxus), eastern cottontail rabbit (Sylvilagus floridanus), raccoon (Procyon lotor), and opossum (Didelphus virginiana). During early historic times and stretching back into the prehistoric period, buffalo (Bison bison) were common in the Blackland Prairie. 


\section{CHAPTER 2}

\section{Prehistoric and Historic Background of San Marcos Springs and the Burleson Homestead}

\section{Britt Bousman and Kevin Schubert}

The area surrounding the San Marcos Springs has been inhabited during every known period of human habitation in Central Texas, from Paleoindian through Historic. The springs and the rich assortment of aquatic and terrestrial plant and animal life that flourish at the springs were and continue to be a strong attraction to people.

\section{Prehistoric Period}

Nomadic large-game hunting characterizes the Paleoindian period between 11,500 and 8800 B.P. (i.e., Before Present), the earliest accepted period in Texas. Paleoindian artifacts have been recovered in past excavations in and around the San Marcos Springs headwaters: within alluvial deposits at the Ice House locality (41HY161) (this site also has a Fish Pond locality); and from underwater excavations at the Spring Lake site (41HY147), directed by Joel Shiner between 1978-1988 (Shiner 1979, 1981, 1983) and Paul Takac in 1990 and 1991 (Takac 1990, 1991a, 1991b). Shiner proposed that Paleoindian groups were semi-sedentary and lived for long periods of time at the springs, where they developed diversified economic strategies that included the hunting of small game and the collection of a variety of plant resources (Shiner 1983). Johnson and Holliday (1983) disagree with the sedentary Paleoindian model proposed by Shiner.

Paleoindian artifacts also have been recovered from disturbed deposits at site 41HY160, and from mixed contexts at site 41HY165 (James Garber, personal communication 2000; Ringstaff 2000). Because Paleoindian sites are few and their geological context is often mixed, this period is poorly understood within Texas. Recent sediment cores have provided evidence of human occupation below a marsh deposit dated to 11,470 \pm 100 B.P. (Beta-132889). This radiocarbon date calibrates to the Gregorian calendar at circa 11,495 B.C.

Following the Paleoindian period, Archaic occupations in Central Texas (that fall between 7000 B.C.-A.D. 800) have been extensively investigated and documented (Prewitt 1981, 1985; Collins 1995). Surveys and excavations along the San Marcos River, Blanco River, Sink Creek, Purgatory Creek, and upland areas near San Marcos revealed abundant occupations and a few well-defined features and structures (Arnn and Kibler 1999; Boes 1994; Ford and Lyle 1998; Garber 1983, 1984, 1987, 1992; Goelz 1999; Godwin et al. 1999, 2000; Harris 1985; Lyle et al. 2000; Ringstaff 2000; Schroeder 1999). 
Particularly notable, a semicircular pattern of postholes, suggesting the presence of a small shelter or windbreak, was excavated at Purgatory Creek at site 41HY163 (Garber 1987). At the nearby Fish Pond locale 41HY161, two human burials were excavated, and these probably date to the Archaic Period, although chronometric age estimates are lacking (Garber and Glassman 1992). At site 41HY160, the Tee Box 6 locality, Archaic occupations were recovered to a depth of $2.4 \mathrm{~m}$ below the surface (Garber et al. 1983). At site 41HY165, Ringstaff (2000) reported the presence of Early, Middle and Late Archaic occupations extending to a depth of $1.2 \mathrm{~m}$ below the surface, and he obtained a radiocarbon date of $2300 \pm 40$ B.P. (Beta-117967) for wood charcoal associated with Feature $3 \mathrm{c}$ at $80-90 \mathrm{~cm}$ below the surface. This date can be calibrated to the modern calendar at ca. 390 B.C.

Archaeologists divide the Late Prehistoric period in Central Texas into two sequential phases, Austin and Toyah (Prewitt 1981; Collins 1995). The two phases indicate distinct cultures found within this portion of Texas. The Austin phase, A.D. 800-1350, has been characterized by a change in lithic technology from large dart points in the Archaic period, to smaller arrow points known as Edwards and Scallorn (Jelks 1962; Henderson 2001). The presence of small projectile points is widely regarded as indirect evidence for the adoption of bow technology. A more distinct lithic tool kit marks the Toyah phase, A.D. 13501650, including scrapers, Perdiz points, beveled knives, and flake drills (Prewitt 1981).

Cemeteries are known from the Austin phase and one was excavated at the Loeve-Fox site in Williamson County (Prewitt 1974). Interments were found with embedded arrow points, which imply increased conflict between Native American groups during this Late Prehistoric period. At sites 41HY160, 41HY37, and 41HY165, evidence of Austin phase occupations surrounding Spring Lake has been recovered (Garber et al. 1983, 1984; Ringstaff 2000). Human burials are rare at Toyah phase sites, perhaps suggesting evidence of few hostilities, although a few that have been found were cremations (Jelks 1962). There is a major shift from the hunting of deer in the Austin phase to the hunting of bison in Toyah phase occupations (Black 1986; Collins 1995). This shift is believed to be due to the reappearance of Bison bison in Central Texas after an extended period of abandonment (Dillehay 1974). Toyah occupations are present at 41HY160 (Katherine Brown, personal observation 2000).

\section{Historic Period}

With the coming of Spanish explorers in the sixteenth century, a dramatic period began in Texas, with new population migrations and catastrophic results for Native Americans. This period can be divided into the Protohistoric period, Spanish and Mexican settlement, and the Anglo settlement.

\section{Protohistoric Period}

The period between the earliest European contact and permanent European settlements is called the Protohistoric period. During the 1500s three historically significant Spanish entradas reached Texas. The first was Cabeza de Vaca's shipwreck on the Texas coast near Galveston Island in 1528. It was followed by the Coronado and De Soto expeditions reaching the Southern High Plains and East Texas in the 1540s. Only a small contingent from De Soto's expedition, after he died, may have reached Central Texas in August 
of 1543 (Swanton 1985; Newcomb 1993). As the chronicler Elvas states:

\begin{abstract}
"There the Indians told them that ten days' journey thence toward the west was a river called Daycao where they sometimes went to hunt in the mountains and to kill deer; and that on the other side of it they had seen people, but did not know what village it was...... after marching for ten days through an unpeopled region reached the river of which the Indians had spoken. Ten of horse, whom the governor had sent on ahead, crossed over to the other side, and went along the road leading to the river. They came upon an encampment of Indians who were living in very small huts. As soon as they saw them, they took flight, abandoning their possessions, all of which were wretchedness and poverty. The land was so poor, that among them all, they did not find an "alqueire" of maize" [Swanton 1985:263].
\end{abstract}

The mountains were probably the eastern edge of the Edwards Plateau at the Balcones Escarpment. The river could have been either the Colorado or the Guadalupe, and the people were probably those known archaeologically as Toyah. This marks the beginning of the Protohistoric period in Central Texas, but the region was not to be visited again for over 100 years.

When the Spanish missions were established in East Texas in the late 1600s, Spanish entradas began to travel regularly through Central Texas. Beginning with Alonso de León's expedition of 1680, the Camino Real (King's Road) was established from Villa Santiago de la Monclova in Mexico to East Texas. This roadway followed established Native American trade routes and trails. These expeditions provide the first detailed written observations on the original Native
American inhabitants and the landscape of the San Marcos area.

Direct and indirect contact with Europeans dramatically altered Native American life during this period. Contact with Europeans affected the Native American communities through disease, internal turmoil, and settlement shifts with the associated results of dramatic population decline, restricted access to traditional resources and lands, and immigration of groups into new territories.

Written records show that various groups camped near San Marcos Springs during the Protohistoric period in the seventeenth and eighteenth centuries, though little is known about these groups. Some of these groups probably lived permanently at or near the springs, e.g., Cantona, Muruam, Payaya, Sana and Yojuane. Others were on bison hunting trips to the Blackland Prairie and their villages were in South and West Texas, e.g., Catqueza, Caynaaya, Chalome, Cibolo, and Jumano (Newcomb 1993; Johnson and Campbell 1992; Foster 1995:265-289). Later, groups migrating south, such as the Tonkawa from Oklahoma, and the Lipan Apache and Comanche from the Plains, moved into the region, and replaced the former groups through attrition from warfare, diseases, and settlement at missions (Dunn 1911; Campbell and Campbell 1985; Newcombe 1961, 1993).

The first recorded crossing of the San Marcos River was in 1690 by Alonso De León. However, initially the Colorado River was called the San Marcos, and the present-day San Marcos River was given other names (Foster 1995). In 1691, as the Domingo Terán de los Ríos expedition approached the Guadalupe and Comal rivers from the south, they encountered a group of 2,0003,000 mounted Indians. On the same expedition, 
Fray Massanet noted that "every year they [Choma, Cibola, Cantona, Cholome, Catqueza, and Chaynaya] come to the headwaters of the Guadalupe River and sometimes as far as the Tejas [Techas] country. They come to kill buffaloes and carry away the skins because in their country, there are not buffaloes. When it gets cold they return to their own country" (Hatcher 1932:58-59). Massanet adds that the "Choma, Cibola, Cantona, Cholome, Catqueza, and Chaynaya are Indians who live in and about the country along the banks of the Rio del Norte [Rio Grande]. They border on the Salineros Indians who live on the banks of the Salado, a river that runs into the Rio del Norte. They also border upon the Apaches with whom they are often at war. The Apaches live in a mountain range which runs from east to west" (Hatcher1932:58). This mountain range is probably the southern escarpment of the Edwards Plateau, west of San Antonio. On June 18, 1691 , the Spanish camped at the Indians' rancheria near the Comal springs at the headwaters of the Comal River. This they called Conaqueyadita which means "where the river rises."

Between June 20-25 of 1691, the Domingo Terán de los Ríos expedition camped at the San Marcos Springs. There they saw many "buffaloes and fish." While at the springs, 110 horses stampeded, and a few days were spent retrieving the scattered horses. Eventually 35 horses were recovered and 75 escaped (Hatcher 1932:15). On June 23, 60 Cantona Indians came to the expedition's camp, which the Indians called Canocanayestatetlo, which means "hot water" (Hatcher 1932:60). Brune (1981:223) attributes this name to the Tonkawa, but the Tonkawa were not at the springs with the Domingo Terán de los Ríos expedition; in fact, they probably were not even in Central Texas at this time (Newcomb 1993). He also noted that the Indians who lived west and south of the San Marcos River spoke the same language, but the groups that lived between the San Marcos and Colorado rivers spoke a different language (Foster 1995:58).

Governor Gregoria de Salinas Varona visited the San Marcos area on June 27 in 1693 (Foster 1995:77-93). On April 15, 1709, the EspinosaOliveres-Aguirre expedition visited the San Marcos Springs (Foster 1995:95-106), and Captain Domingo Ramón's expedition with Espinosa and Saint-Denis were at the springs on May 20, 1716 (Foster 1995:109-125). Governor Martín de Alarcón led an expedition that reached the San Marcos River on May 9, 1718, and on the return trip he named it the "Rio de Inocentes" on May 13, 1718 (Hoffman 1935:85; Foster 1995:169). A few years later the Marqués de San Miguel de Aguayo visited the San Marcos Springs on May 19, 1721 (Santos 1981; Foster 1995:145161). In addition, Brigadier Pedro de Rivera's inspection tour reached the San Marcos area on August 21, 1727 (Foster 1995:163-175; Jackson 1995). From the first crossing of the San Marcos River in 1690 by Alonso De León, at least eight expeditions visited the San Marcos area during a 37-year period.

Spanish settlement in Central Texas first occurred in San Antonio with the establishment of Mission San Antonio de Valero (the Alamo) in 1718 and the later founding of San Antonio de Béxar (Bolton 1970 [1915]; Habig 1968; de la Teja 1995). However, the first Spanish settlement in San Marcos was not until 1755. In August of 1755 the San Francisco Xavier de Horcasitas, San Ildefonso, and Nuestra Señora de la Candelaria missions, and the San Francisco Xavier de Gigedo Presidio were abandoned on the San Gabriel River near Rockdale and established on a temporary basis at the San Marcos River. Originally, the San 
Francisco Xavier de Horcasitas Mission was established for the Tonkawan groups known as Yojuane, Mayeye, and Ervipiame. San Ildefonso Mission was founded for the Atakapan groups called Akokisa, Bidai, and Deadose. Mostly Karankawan groups such as the Coco, Top, and Orocoquisa populated Nuestra Señora de la Candelaria Mission, but the Bidai, an Atakapan group, was also recorded at this mission (Bolton 1976).

Many factors led to the abandonment of the San Gabriel missions: drought, an epidemic, immoral behavior of the soldiers and commander, Apache attacks, neophyte desertions, and unhealthy conditions. Even though the exact location is not known, historic records clearly indicate that between 1755 and 1756, the San Xavier missions were temporarily located on the San Marcos River (Bolton 1970:263-278 [1915]). While the missions were at the San Marcos, over 1,000 Lipan Apaches joined the missions. The Apaches convinced the Spanish missionaries to establish a mission and presidio for them in their own land to protect them from Comanches. In 1756 the property from the San Xavier missions was assigned to the ill-fated Santa Cruz de San Sabá Mission, and in 1757 the presidio soldiers were assigned to the new San Luis de las Amarillas Presidio near the new mission. Both were established near the present-day town of Menard on the San Sabá River (Weddle 1964). The neophytes from the San Xavier missions at San Marcos were sent to the San Antonio missions, except for the Mayeyes. The Spanish built a separate mission for them on the Guadalupe River near New Braunfels, but it was abandoned in 1758. We have found no documents that describe the community or the people at San Marcos, and thus we are placing this within the Protohistoric period.
After the missions at the San Marcos were removed, the best record of Spanish visiting the San Marcos Springs comes from letters written by Athanase de Mézières to Teodoro de Croix. The first letter, dated to September 25, 1779 states:
"Having halted near the head of the San Marcos River, a worthy rival of the San Xavier [Brushy Creek] in respect to the conveniences which it offers for settlement, I have seen with wonder that it owes its origin to a huge rocky bluff, which emits from an ill-proportioned mount such a volume of water that it once becomes a river. One sees in the neighborhood several caves, with wonderful formations; here are some steps, an altar, frontal candlesticks, and a font; there, curtains, festoons, flowers, images, and niches, all so clean that they appear to be in some one's charge. And there is no lack of benches, which invite the spectator to contemplate at leisure figures, some sacred, some profane, upon which nature has spent so much care that our Europe may well grieve at not being endowed with their equal...I have just dispatched an official communication to the chevalier governor of Bexar to notify him of a trail of ten or twelve men, which I saw at San Marcos, and which was seen again at Guadalupe in my opinion, they are coming with evil intent and to report to him the entrance of the Tancaques, so that if the first are Lipanes, their meeting may not have disastrous consequences May God, etc. Salado, September 25, 1779. I kiss the hand of your Lordship, etc. Atanasio de Mesieres" [Bolton 1914:(II)83285].

Later, in a summary of Athanase de Mézière's letters, on May 23, 1780, de Croix states "The San Marcos River rises in a large channel of water which springs from a great rock, in the 
neighborhood of which are wonderful crystallizations which represent various figures" (Bolton 1914:(II)315).

The only evidence of Native American occupation at the springs during the Spanish period comes from the site 41HY165. Here Ringstaff (2000) excavated a single Mission projectile point. These small lanceolate points are commonly found at the San Antonio and northern Mexican missions, but are extremely rare at other sites. Ringstaff (2000) did not find any features, artifacts, or other evidence of Spanish occupation.

During the period of Spanish settlement, the Tonkawa tribe became associated with the San Marcos Springs. Perhaps this was due to the presence of the missions at the springs in the 1750 s, but certainly the movement of the original groups away from the San Marcos Springs was another factor. Many of the earlier groups were drawn into the San Antonio missions, many died from disease, and invading and hostile Apaches were pushing south. Much of what we know about the Tonkawas is described by Newcomb (1961, 1993). Recent linguistic study shows that the original seventeenth and eighteenth century Native Americans in Central Texas such as the Sana were not Tonkawa (Johnson and Campbell 1992). Apparently the Tonkawa migrated south from Central Oklahoma during the Protohistoric period.

In the latter half of the eighteenth century, the area north of the Guadalupe River was unsettled; the lands were the King's Lands (realengas) and neither the missions nor the ranchers could herd the wild cattle grazing on these lands (Jackson 1986:59-60). Jackson (1986:184-185) indicates that a plan was developed to move the Adaesanos (displaced people from Los Adaes) to the area between the San Marcos and the Guadalupe rivers in order to alleviate the need for agricultural and grazing lands at San Antonio. At that point there was a great deal of tension between the missions and the citizens of San Antonio de Béxar. On August 2, 1772, the Baron de Ripperda, from San Antonio, wrote to the Viceroy stating:

"I ought to inform your Excellency that if the establishment of a presidio in the cordon, which the nations recently become friendly ought to form, should come to pass, as they request and with the efficiency and importance which I have represented to your Excellency, then the former presidio would not be necessary. But a pueblo protected by a small garrison or detachment would be very important and useful so long as the Comanche nations continues to commit depredations upon us. In view of the beautiful location of the place, which is well stocked with cattle, and of its convenience for lending a hand to this presidio, it would form a station on the way to the presidio planned, and latter, one on the way to Luisiana" [Bolton 1914:(I)335-336].

The plan for a fort and settlement on the San Marcos River was not enacted, as it was decided in 1779 that the Adaesanos would be allowed to take over the agricultural lands of the Mission Valero. By this point the San Antonio missions were in a state of decline and this marks the first step in their secularization. However, the Adaesanos were never actually allowed to use the Valero land, but that is a different story (Jackson 1986:185).

\section{Spanish and Mexican Settlements}

The first permanent Spanish settlement near San Marcos was along the San Marcos River downstream of the present town, at a village 
named San Marcos de Neve, founded April 1, 1808, by Don Filipe Roque de la Portilla (Horrell 1999:66). The town was the last town settled in Texas under the name of the King of Spain. The small village was abandoned in 1812 due to Tonkawa and Comanche Indian harassment and severe flooding (Horrell 1999:63-71). It is not clear how, or if, the settlers from San Marcos de Neve used the headwaters of the San Marcos River.

The events that changed Texas during the 1820 s and 1830s-the Mexican and Texan revolutions-were little evidenced at the San Marcos Springs. However, these changes, which had an immense effect on San Antonio, set the stage for the next major historical period.

\section{Anglo Settlement}

After the Texas revolution, in 1840 a series of forts was constructed within Texas under a new law passed in December 1838- "An Act to Provide for the Protection of the Northern and Western Frontier" (Texas Republic 1839). The law called for military roads and forts to be erected from the Red River to the Nueces River. One of these forts, Post San Marcos, was erected at the headwaters of the San Marcos River to facilitate the building of a more direct road between San Antonio and the newly established capitol at Austin, in order to safeguard travel. Adjunct General Hugh McLeod laid out the fort, which was to be garrisoned by a company of 56 men. Captain Josepf Wiehl's company, the First Infantry Regiment, occupied the fort. The fort and route were completed in October 1840, and shortened travel between the two important towns by ten miles. The exact location of the fort has never been determined (Pierce 1969:150-151).
William Lindsey surveyed and laid out the road from Austin to Post San Marcos. In March 1841, the Texas army was disbanded and Post San Marcos troops were marched to Austin and discharged (Pierce 1969:151). The road still exists and is known in San Marcos as Post Road. The next major activity in the San Marcos area would be the Veramendi family selling their holdings of land between San Antonio and Austin.

\section{Historical Background of the San Marcos Springs Area}

\section{The Settling of San Marcos}

Juan Martín de Veramendi, a native of San Antonio and the ninth governor of Coahuila y Texas under Mexican rule, received a land grant in 1831 consisting of two leagues in the area that is now San Marcos. When he died of cholera in 1833 in Saltillo, portions of his holdings, including land in the San Marcos area, were inherited by his daughter, Maria Josepha Veramendi Garza. She and her husband, Rafael Garza, sold some of this land to William Lindsey at San Antonio before Lindsey surveyed the road to Post San Marcos. They also sold 640 acres of land that included the San Marcos Springs to Nathaniel Lewis on December 22, 1840 (Figure 2-1) (Hays County Deeds and Records [HCDR] Vol. A:10). On August 21, 1845, General Edward Burleson and Dr. Eli T. Merriman bought 640 acres from Nathaniel Lewis, including the headwaters of the San Marcos and the surrounding area (HCDR A:169). The portion that Burleson acquired included the headwaters and springs of the San Marcos River. From this point on, the San Marcos Springs were associated with General Edward Burleson. 


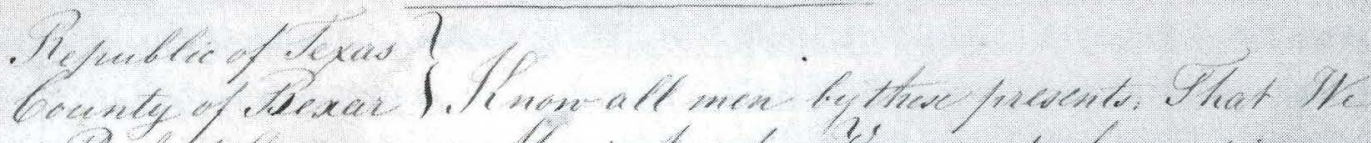

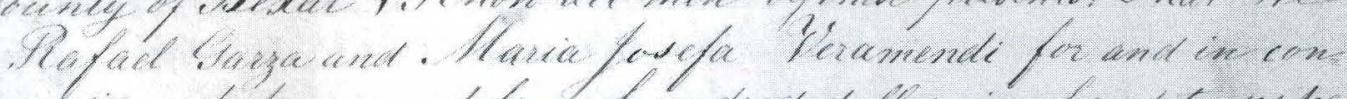

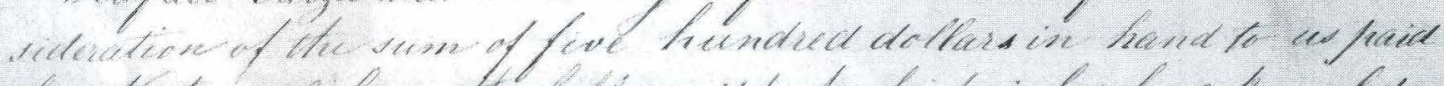

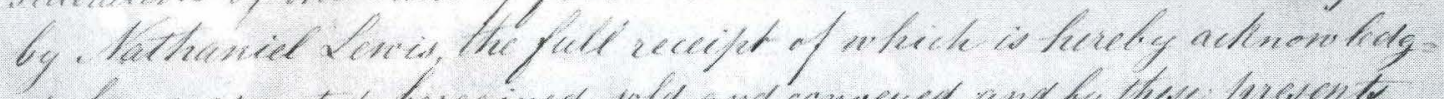

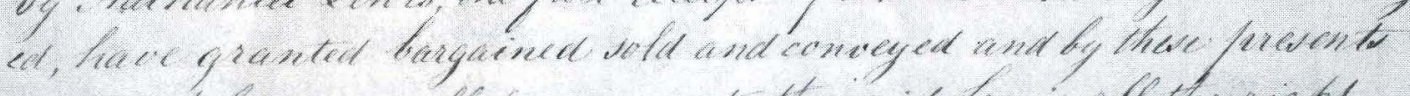

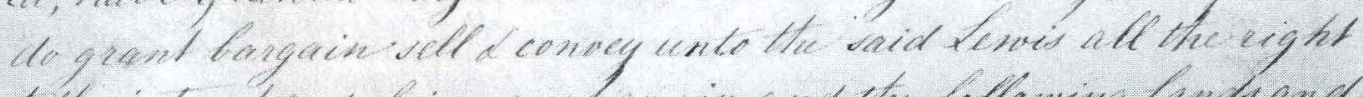

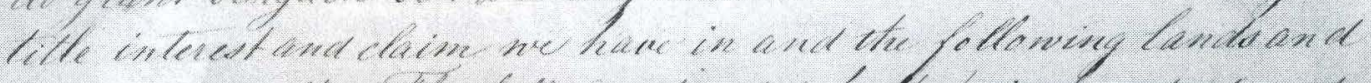

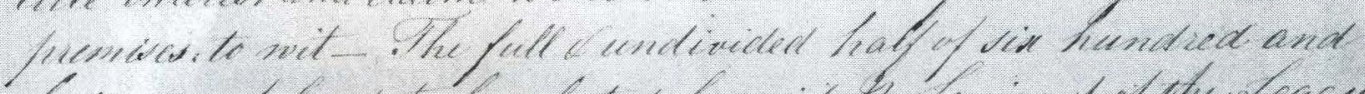

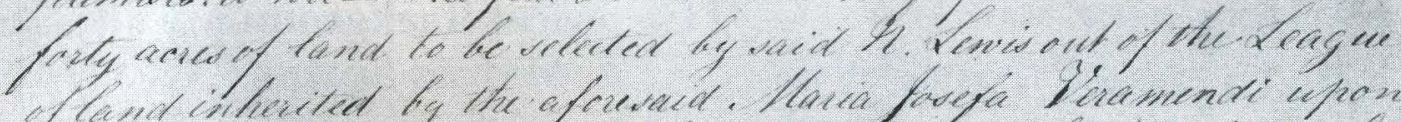

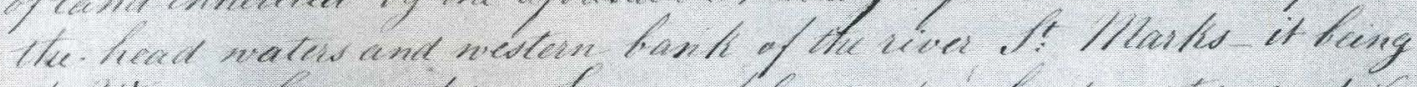

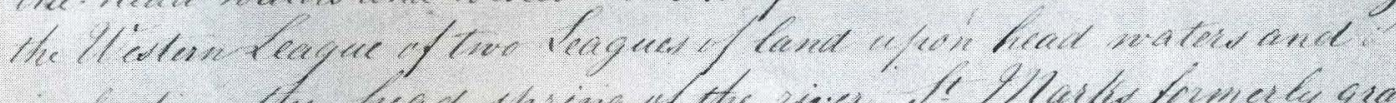

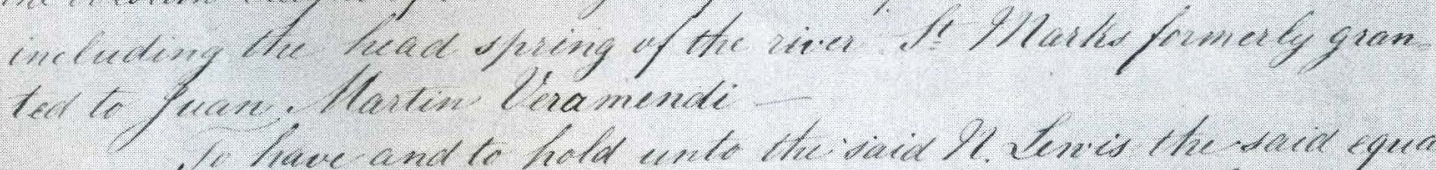
- Is have and te hold eneto the said It. Teneis the deid equnt

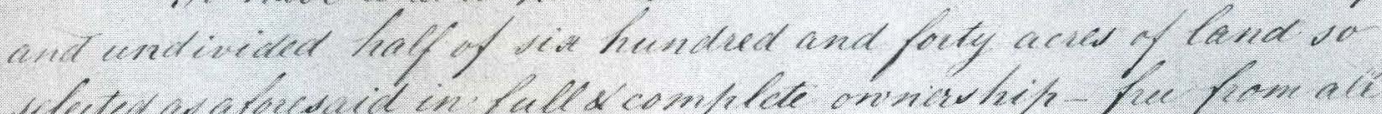

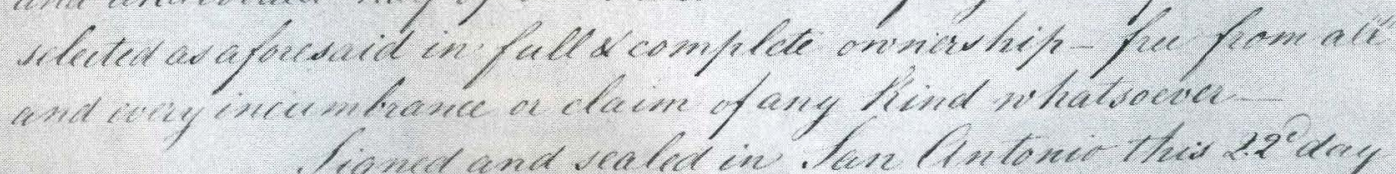

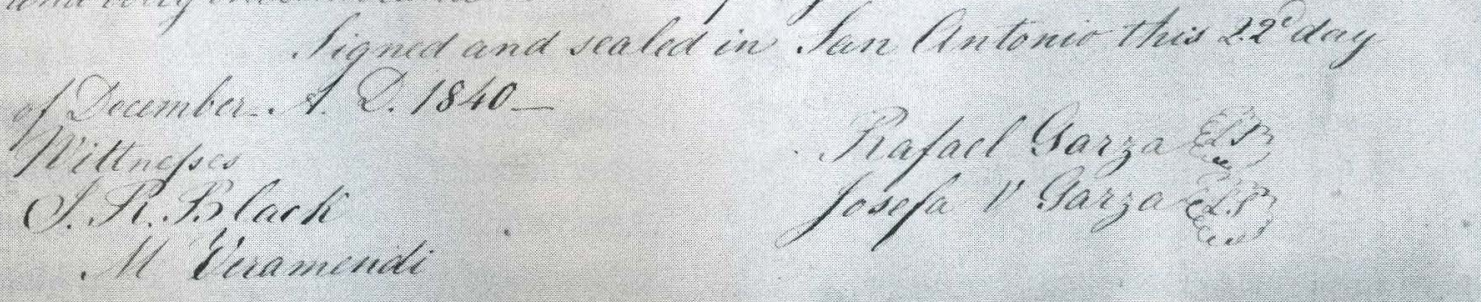

Figure 2-1. 1840 deed for purchase of 640-acre tract by Nathaniel Lewis from Maria Josefa Veramendi Garza and Rafael Garza.

A year after Burleson bought the San Marcos Springs, William McClintock, a volunteer with the Second Kentucky Regiment during the War with Mexico, and who was killed in February 1847 in the Battle of Buena Vista, wrote the following description of the springs, San Marcos, and the surrounding area:

" 2 miles north of St. Marks we crossed the Blanco, a mountain torent of purest water, narrow and deep, there is the finest spring or springs (for they are not less than 50 in a distance of $200 \mathrm{yds}$.) I every beheld. These springs gush from the foot of a high cliff and boil up as from a well in the middle of the channel. One of these, the first you see in going up the stream, is near the center, the channel is here $40 \mathrm{yds}$. wide, the water 15 or 20 feet deep, yet so strong is the ebullition of the spring, that the water is thrown two or three feet above the surface of the stream. I am told that by approaching it in canoe, you may see down in the 
chasm from whence the water issues. Large stones are thrown up, as you've seen grains of sand in small springs, it is unaffected by the dryest season. I am persuaded that the quantity of water which is carried off by this stream in the course of a year is greater than that by the South Licking, it is about 60 feet wide and 3 feet deep on an average, with a currant of not less that ten or fifteen miles per hour. Great numbers of the finest fish; and occasionly an alligator may be seen sporting in its chrystal waters. The town of St. Marks, (that is to be, for it is only born and christened, the first of the four houses, it contains having been put up four weeks since) stands on one of the loveliest spots in nature. Immediately in rear of it, to the north, a range of romantic woody hills extends away for many miles to the west, terminating at the north in an abrupt cliff from which issues the spring. The spring branch (St. Marks river) runs half round the place in a semi circle forming the $\mathrm{e}[\mathrm{a}] \mathrm{stern}$ and southern boundary. at the west, the prairie rises in easy and regular swells for miles away. These swells are mostly cover'd with clumps of live oak, or groves of post, or pecan. The town site containing a mile square slopes from the center to the east, south, and west, a number of trees standing singly, or in groups cover this area, many of them hung with graceful festoons of Spanish moss. The margin of the stream, and sides of the hills are adorned with innumerable flowers and shrubs. In the eddies of the stream, water cresses and palmettos grow to a gigantic size. Great quantities of game in the neighbourhood. It was a few months since, a favourite resort and camping ground for roving bands of Comanches" [McClintock 1931:32-33].

\section{History of the Burleson Cabin Property}

\section{General Edward Burleson's Life}

The information in this section has been recorded and documented in various sources pertaining to the Texas Revolution and General Edward Burleson. The primary sources that have been used are two important works: Francis Stovall's book Clear Springs and Limestone Ledges (Stovall et al. 1986); and Jenkins and Kesselus' book, Edward Burleson: Texas Frontier Leader (1990).

Edward Burleson (Figure 2-2) was born on December 15, 1798, in the Blue Ridge Mountains of North Carolina. His parents were James Burleson and Elizabeth Shipman. James Burleson and his family continually moved with his older brother, Joseph, and his family. Throughout Edward Burleson's life they moved from North Carolina to Mississippi, then to Tennessee, Alabama, Missouri, back to Tennessee, and finally to Texas.

\section{Military and Political Career}

The political career of Edward Burleson began at a young age in the War of 1812 when his father, James, served as captain of the Tennessee Volunteers. They fought in the Creek War under Andrew Jackson while young Edward kept muster roll for the company. He then fought in the Battle of Horseshoe Bend. In this battle the Creek Indians were defeated and forced to move from Alabama.

On April 25, 1816, at the age of 18, Edward Burleson married Sarah Griffin Owen in Madison County, Alabama. Five years later they were living in Howard County, Missouri, where he served as 


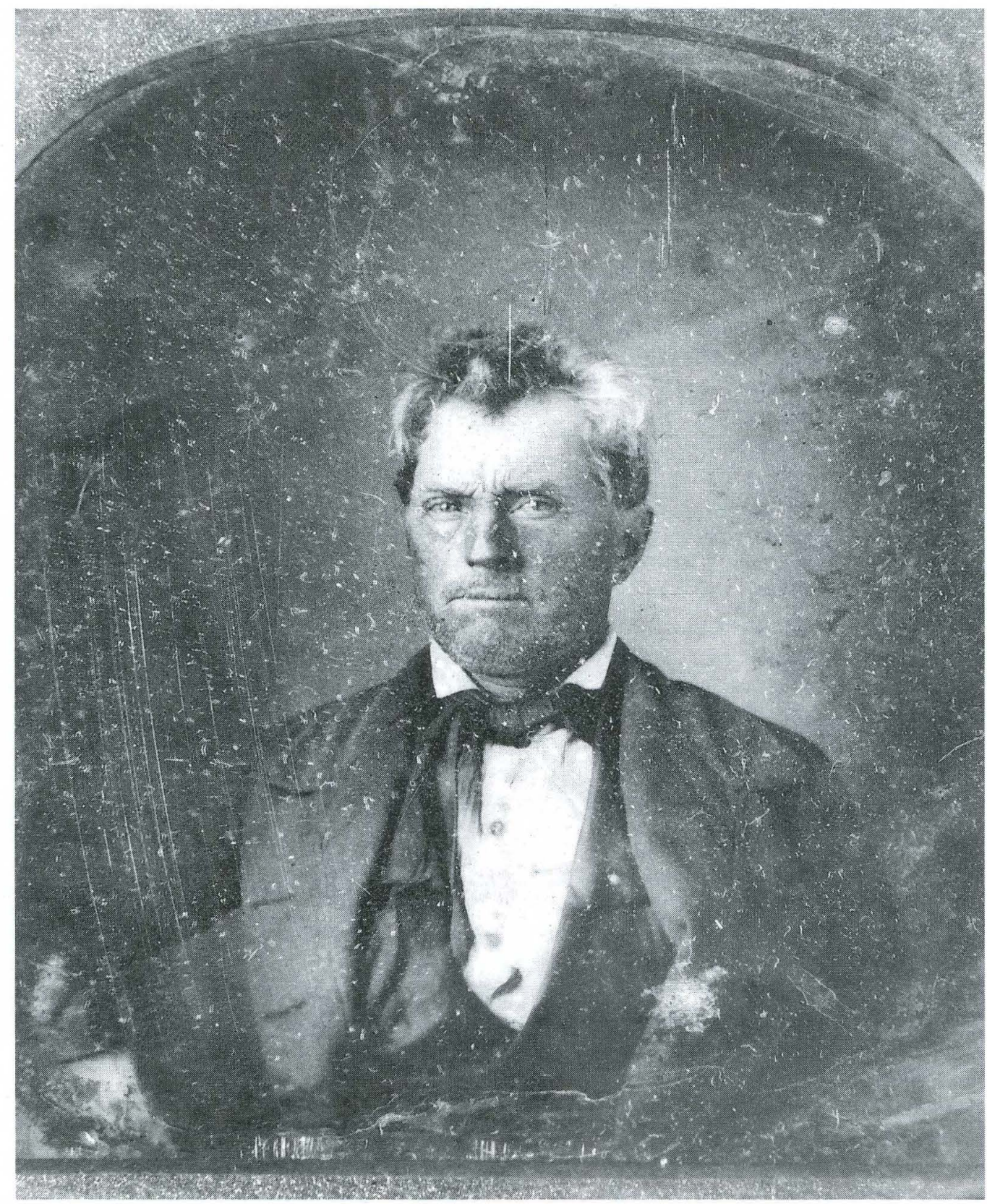

Figure 2-2. Portrait of General Edward Burleson (Texas State Library \& Archives Commission).

Colonel of the First Missouri Regiment of Militia. Beginning in 1827, while living in Tennessee, they had four children: Mary Jane, John, Edward Jr., and Joseph Rogers. In Hardeman County, Tennessee, Burleson was Colonel of Rangers.
During a visit with his father in 1829, Edward Burleson came to Austin Colony in Texas to assess the business potential of the land. The following year Burleson's family moved to Texas. Edward Burleson's father, James, and his brothers Aaron, Jacob, Jonathan, and Polk, as well as his Uncle Joseph's family, moved to Stephen F. Austin's 
second colony in Bastrop County, Texas in 1830. That following year his daughter Grace was born.

On August 11, 1832, at San Felipe de Austin, Edward Burleson was a member of the ayuntamienta governing the counties of Austin, Bexar, Goliad, and Guadalupe. He was elected Lieutenant Colonel of the Militia in San Felipe de Austin on December 7, 1832. In 1833 he served as a delegate from the municipality of Mina to the Convention of 1833 at San Felipe. On May 17, 1835, he was elected to the Committee of Safety in Bastrop and was not able to attend the consultation of 1835 , though he was an elected delegate.

In response to calls for volunteers in Goliad during the Texas Revolution, Edward Burleson and his father gathered men from Bastrop and traveled to Gonzales. On October 10, 1835, he was elected Lieutenant Colonel of the infantry in General Stephen F. Austin's army. On November 24 of the same year he became General of the Volunteer Army, replacing Stephen F. Austin, who the Provisional Government made Commissioner to the United States. Events developed quickly. Two days later Burleson fought in the Siege of Bexar, known as the Grass Fight, where Ben Milam was killed by a shot in the face (Tennis 1995). Texian troops won the Grass Fight and immortalized Ben Milam.

On December 1, 1835, the Provisional Government commissioned Edward Burleson as Commander in Chief of the Volunteer Army. In Gonzales on March 10, 1836, he was officially elected Colonel of the Infantry, First Regiment. He commanded the First Regiment at the Battle of San Jacinto on April 26, 1836, where Houston's troops fought and defeated General Santa Anna's Mexican army. After the battle General Juan N.
Almonte surrendered to Burleson. General Santa Anna was escorted back to Mexico, but never accepted Texas as a separate entity from Mexico. During the months of July through December of 1836 Burleson served as the Colonel of the Frontier Rangers.

In 1837 Edward's wife Sarah bore another son, David Crockett Burleson, named after the Tennessee soldier and U.S. senator who died at the Alamo. That same year Burleson surveyed and laid out roads from Bastrop to La Grange and other Central Texas towns. As the Republic of Texas evolved, the First Congress established a militia and appointed Burleson as Brigadier General in 1837. On September 26, 1838, through May 1839 , he served as Representative of the Second Congress, and held positions on the Committee on Post Offices and Post Roads, Committee on Military Affairs, and Committee of Indian Affairs, where he served as Chairman.

Burleson also served as Colonel of the First Regiment of Infantry in the New Regular Army in 1838. On April 4 he and the New Regular Army defeated Mexican insurrectionists under Vicente Cordova. He was elected in 1838 to the Senate of the Third Congress but resigned January 19, 1839 (at President Mirabeau B. Lamar's request) in order to take command of the Frontier Regiment. While commanding this regiment, the Battle of Brushy Creek, near present Taylor, took place in February 1839. During this battle, Edward's brother, Jacob Burleson, was killed by Comanche raiders.

May of 1839 marked a turning point in the relations between the Texans and the Cherokee. Edward Burleson intercepted a Cordova agent on May 22 with proof that Mexico had made allies with Cherokees and other Indians. During July 
1839, he and his Frontier Regiment defeated the Cherokees under Chief Bowl. Chief Bowl was President Sam Houston's informant and friend, and was killed in this particular battle.

In the spring of 1838 Burleson helped survey the town of Waterloo. This small community was comprised of only two or three families. As the Republic of Texas was developing, there was a debate on the location of the capitol. Edward Burleson and Lamar were major proponents for the capitol to be located in Waterloo. Sam Houston opposed this, instead proposing for the capitol to be located in Houston. Burleson, President Lamar, and others received their wish in 1839 when Edwin Waller laid out a street plan for the future capitol. On October 17, 1839, General Edward Burleson was in charge of the ceremonies establishing Waterloo, later renamed Austin, as the capitol for the Republic of Texas.

On December 25, 1839, another altercation with the Cherokees took place. Burleson and the Frontier Regiment again defeated the Cherokees at Pecan Bayou. At this battle Chief Bowl's son, John, and another chief known as Egg were killed. Burleson sent Chief Bowl's hat to Sam Houston, which enraged him. The defeat at Pecan Bayou marked the last fight with the Cherokee in Texas.

In 1840 Burleson's wife, Sarah, bore a seventh child, named Elizabeth. Two months before Elizabeth was born, Burleson and the Frontier Regiment defeated the Comanche at the Battle of Plum Creek near Lockhart. This was a running battle against a Comanche raiding party that had sacked Linneville, near the coast. The following year General Burleson was elected Vice President of the Republic of Texas and Sam Houston was elected President. Burleson was inaugurated on December 10, 1841.
In the spring of 1842 the Mexican army invaded Texas under General Rafael Vasquez. This prompted Burleson to meet with volunteers in San Antonio and he was elected to command them. Sam Houston sent Alexander Somervell to San Antonio to take over command of the volunteers. Burleson handed over the command to Somervell and made his famous speech before the Alamo. In this speech Burleson said, "Though Thermopolae had her messenger of defeat, the Alamo had none."

In the year of 1842 Santa Anna launched another attack to invade Texas, this time commanded by the Mexican General Adrian Woll. Burleson again quickly raised volunteer troops for the defense of the nation. President Sam Houston again sent General Somervell to take over command, which Burleson yielded to him. Clearly, Burleson was a thorn in Houston's side.

In 1844 Edward Burleson ran for the Presidency of the Republic of Texas. Though he was a war hero, supported annexation, and was admired by many, he was not considered a politician. Anson Jones defeated him for the position by a small margin of 2,000 votes. On December 29, 1845, the Congress of the United States signed an act to make Texas the twentyeighth state in the Union. This same month of the same year, Burleson was elected senator from the Fifteenth District to the First Legislature of the State of Texas. The Fifteenth District was comprised of Bastrop and Travis Counties, which still included San Marcos. He was then unanimously elected President pro tem for two months while the election for Lieutenant Governor was under way. On March 18 the Senate passed a bill creating a new county named in Burleson's honor. 
In 1846 the Mexican war began with the United States. During this war Edward Burleson and Governor of Texas James P. Henderson went to Monterrey, Nuevo Leon. Here Burleson was appointed Senior Aide-de-camp for General Henderson. He held the rank of major and served as a spy during the siege of Monterrey and Buena Vista. This was Burleson's last military engagement.

During the period between 1846-1849 Edward Burleson served as a senator for the Fifteenth District. While in office he sponsored the bill to create Hays County. On March 1, 1848, Hays County was created and named for Colonel John Coffee Hays, a noted Texas Ranger and veteran of the Mexican War. Colonel Hays surveyed the road from Austin and San Antonio to El Paso. During the same year Burleson served as Chairman on the Committee of Military Affairs. The committee awarded a $\$ 1,250,000$ grant to Texas for Indian depredations.

On December 26, 1851, General Edward Burleson died from pneumonia in Austin at N.C. Raymond's home. He was serving as senator from the Twenty-first District, and was elected President pro tem again. General Burleson was buried in the Masonic Cemetery, which became the State Cemetery. The State of Texas purchased the cemetery in his honor in 1854 . He was the first person buried at the State Cemetery. The headstone presently at his gravesite reads:

(top)

In Memory of Gen. Ed. Burleson of the Texas Revolution Died Dec. 26, 1851 Aged 53 years

(front)

Dec. 15, 1798 - Dec. 26, 1851

Colonist-Soldier-Politician. 1830

Family came to Texas $1836 \mathrm{Cmdr}$.
Of 1st Reg. Battle of San Jacinto 1837 Member of Texas House of Rep. 1838 Member of Texas Senate 1839 Founded Waterloo now Austin, Texas 1841 Vice President Texas Republic 1844 Chairman Texas Annexation Committee Served the State of Texas in other capacities until his death in 1851

During the years that Burleson lived in San Marcos and until his death, he traveled to Austin while in legislature, staying in the Bullock Hotel or with friends when the legislature was in session.

\section{Burleson's Homesteads and Life at Bastrop and San Marcos}

On April 4, 1831, Burleson was granted a league of land in Stephen F. Austin's second colony in Bastrop County. The land grant was far from the town and deep into Indian Territory. Situated on the east side of the Colorado River about fourteen miles downstream from Bastrop, he built his first cabin in Texas near a small spring. The topography of the land included an extensive floodplain, a higher prairie, and a hill filled with timber. The spring created a creek which ran through the eastern side of the property. The creek was known as Burleson Creek.

In July 1835 Burleson sold his original Mexican land grant, including his first cabin, and bought land that comprised Thomas Thompson's 1,107-acre Mexican land grant. The land is on a low prairie along a straight stretch of the Colorado River and runs three miles deep to a ridge away from the river. Below a hill Burleson named Mount Pleasant, he built his new cabin. On Mount Pleasant was a pine forest, which is known as Lost Pines. A post office, in use during April 1838 through June 1841, was established near Burleson's home and named Mount Pleasant. The 
Burlesons sold their plantation, Mount Pleasant, on October 3, 1848, to their relatives Volley and Ezekiel Owen for \$2,375 (Bastrop County Deeds and Records Vol. F:326).

One of Edward Burleson's closest associates was Dr. Eli T. Merriman. Dr. Merriman arrived at Galveston in 1838. From there he traveled by buggy to Bastrop, where he met Burleson. Merriman received a degree from Yale and went on to further his education at the University of Pennsylvania and the Vermont Academy of Medicine. He shared similar animosities with Burleson towards Sam Houston, and became a major proponent for Burleson when he was Vice President and while he was running for the Republic's presidency. Merriman settled in San Marcos shortly after purchasing land and was appointed postmaster of the settlement in December, 1846. He built his homestead at the southwest corner of the intersection of Hopkins Street and Edward Gary Street, where the Goodyear building is now located. Merriman's original log cabin was located on the Aquarena Springs grounds, but is now being restored.

In 1846 General Edward Burleson joined with William Lindsey and Dr. Eli Merriman to found the city of San Marcos by employing James R. Pace to survey a piece of land that would become the city. Out of this survey they donated land to create town lots, streets, a cemetery, and a public square. They also marked off 12-acre farm lots between the streets of Burleson and San Antonio. As settlers came, they each received one town lot. The town of San Marcos was officially established in 1851 .

In 1848 , three years after buying the San Marcos Springs from Nathaniel Lewis, Burleson built a cabin with the help of his sons, on the hill overlooking the San Marcos Springs. "The traveler who passes San Marcos will see North of the road, perched on the high bluff which overlooks the San Marcos head spring a rude log house, built by General Burleson when he was at that place, the outside settler" (Wilbarger 1985:58 [1889]). Burleson and his family built the cabin and constructed it of elm and oak logs, roofed with clapboards hewn by hand. There were two rooms approximately 16 by 18 feet, with a dogtrot separating them. The floor was laid on puncheons. There was a large rock chimney on the north end. The original cabin sat where the gondola tension station now sits atop the hill overlooking the springs, sometimes known as Rogers Ridge. In 1960 Paul Rogers ordered the dismantling of the original cabin for fear of children injuring themselves (Isabel Gutierrez, personal communication 2001; see interview in Appendix J).

Burleson used the fertile land directly across the headwaters of the San Marcos River between the springs and Sink Creek as farmland (Bracht 1848). The area Burleson owned around the springs was also used for the grazing of animals. At the time of his death in 1851 he owned five horses, one jackass, 60 head of cattle, 30 hogs, 60 goats, and one yoke of oxen (Hays County Probate Records [HCPR] Vol. A:178). Burleson received the first brand in Hays County, "EB" (Figure 23 ). The brand was recorded on October 21, 1848, and was later transferred to his son, Davie Crockett Burleson (HCDR, Brands Vol. 1:1).

In 1849 Burleson built the first dam across the San Marcos River, to operate a gristmill. It is believed that Burleson would not have built the mill before he built his house in 1848 , and the best evidence for the dam's construction comes from the Austin Texas State Gazette newspaper 

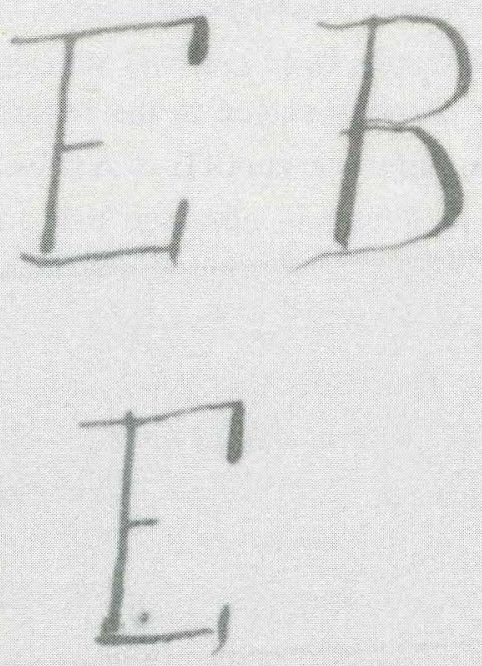

Figure 2-3. The early brands registered to General Edward Burleson.

(Texas State Gazette, 1 December 1849:119, col. 2), and the Austin Tri-Weekly Gazette (Tri-Weekly Gazette, 3 December 1849:3, col. 2), advertising the sale of a mill on the San Marcos River. Burleson's mill was the first mill built on the river and this advertisement indicates that the mill, and thus the dam, were functioning by late December in 1849. The dam formed Spring Lake. The actual location of the mill would have been where the Ice House, now Joe's Crab Shack, is located. This is the oldest of five nineteenth century mill sites in the city of San Marcos, all now abandoned.

Edward Burleson also built the first schoolhouse in San Marcos. Originally it was located on top of the hill near his house for his school-age children, David C. and Elizabeth Burleson. It was built with plank lumber sawed from his sawmill. The schoolhouse was later moved down the hill to a better location for other children in the community. The new location of the schoolhouse was near the river, opposite the $\log$ store owned by Caton Erhard, who was the first county clerk. The schoolhouse building was not only used as a school, but also functioned as the courthouse and church until 1854 (San Marcos Daily Record [SMDR], 29 April 1979).

General Edward Burleson, through his years of battles, acquired an acquaintance with a Tonkawa Indian, Chief Placido. Chief Placido served Burleson for many years as his scout on the Battle of Plum Creek and other engagements, living fifteen years after Burleson's death. The Chief would visit Burleson annually with his family in San Marcos. Surprisingly, it was the close association with Edward Burleson that provided protection for the Tonkawas during the Texas Republic period. After Burleson's death, the Tonkawa tribe was persecuted, individuals murdered, and finally the surviving remnants were driven into Oklahoma (Himmell 1999).

During the time Burleson and his family lived in San Marcos, there was a newly organized Methodist Church, which met at John Pitts' home and was led by Rev. A. B. F. Kerr. Burleson's daughter, Grace, was the first to join the church after charter members organized it. Her father, Edward Burleson, eventually became the second convert and was baptized then. It is reported that after the baptism he said to Will Pitts, "I have fought many a battle and gained many victories but this is the greatest victory of them all." After his death Burleson's family was still living in the cabin that he built above the San Marcos Springs. General Edward Burleson was survived by his wife, Sarah Burleson; his seven children: Mary Jane, John, Edward Jr., Joseph, Grace, David C., and Elizabeth; and his nephew, Edward Burleson. Sarah Burleson ultimately died on April 14, 1875, and is buried in Oakwood Cemetery in Austin near the Texas State Cemetery. 
General Edward Burleson served Texas in thirty-four battles during his life. He was never defeated. His love and admiration for the state of Texas was shown through the offices he held and the battles he fought. The accomplishments of his life are numerous and show his commitment to the State of Texas.

\section{Later Ownership of the 'Homestead Tract'}

In 1851 Edward Burleson died, and his estate was split between his wife and his children. Burleson's wife, Sarah, remained in the cabin. On February 15, 1855, Edward Burleson's will was probated (Figure 2-4) and his deed for the homestead tract was released to Sarah Burleson (HCDR B:543). She sold the property on October 19,1857 , to Cephas Thompson for $\$ 3,500$ (HCDR C:454). It is not known if Thompson resided at the cabin. In 1866 Cephas Thompson died, but still owed Sarah Burleson $\$ 1,400$ for the remaining mortgage of the property. Because of the debt owed to her, the administrator of Thompson's estate, Edward Burleson, Jr., put the property up for sale. During the months of January 1866 through May 1866, Edward Burleson, Jr. grew crops on the land to accumulate payment of the debt owed (HCPR B:165).

On May 1, 1866, the property was sold to L. M. McGehee for the amount of \$3,500 (HCDR $\mathrm{D}: 572)$. It is not known if McGehee resided on the property, used it for farming, or rented it. On February 7, 1872, the property was sold to Harvey North for \$4,500 (HCDR G:550). Again, it is not known how the land was used. After five years of ownership, North sold the land and cabin to F. M. Noble on Sept. 24, 1877, for $\$ 4,500$ (HCDR $\mathrm{K}: 498)$. After less than two years Noble sold the land and cabin to E. S. Jennison for $\$ 5,500$ on May 17, 1879 (HCDR M:164).

The property stayed in the Jennison family for twenty-one years until E. S. Jennison died and Louisa A. Jennison obtained title to the land (HCDR 39:202). On May 1, 1900, she sold the property to Edward J. L. Green for \$6,000 (HCDR 39:220). The street that runs past the original cabin's location is named after Green. Green at the time was the President of the San Marcos Water Company and sold the land three months later to the company. On August 7, 1900, the San Marcos Water Company bought the land for $\$ 15,000$ (HCDR 39:325). The cabin collapsed in 1917 from a heavy rainstorm, during the time of the company's ownership.

On May 19, 1926, A. B. Rogers purchased the homestead tract, including the cabin, for \$21,466 (HCDR 91:458). A. B. Rodgers built a hotel in 1929. The building is $200 \mathrm{ft}$. long and 34 $\mathrm{ft}$. wide. The hotel was ultimately finished in April 1929, and opened that same month (San Marcos Record [SMR], 19 April 1929). The hotel still stands and has been used continuously as a hotel since its opening, except for a time during the depression in the 1930s when it was occupied as a health resort (SMR, 16 February 1934). On August 6, 1949, Paul Rogers bought the land from his parents for $\$ 20,000$ and founded Aquarena Springs there (HCDR 144:330). Paul Rogers died in 1965, a year after the construction of the replica cabin.

On September 5, 1985, the Paul J. Rogers Trust sold Aquarena Springs to Baugh/Moore I Joint Venture for \$2,631,168.90 (HCDR 546:534). This corporation changed names to Aquarena Springs Corp. \& May Springs Ltd. Southwest Texas State University purchased the land on 
January 24, 1994, for an undisclosed sum (HCDR 1046:546). Texas State University-San Marcos now occupies the facilities as an educational and research park.

\section{History of the 'Mill Tract'}

After General Edward Burleson purchased the property from Nathaniel Lewis, he immediately went to work developing the land. A year after the

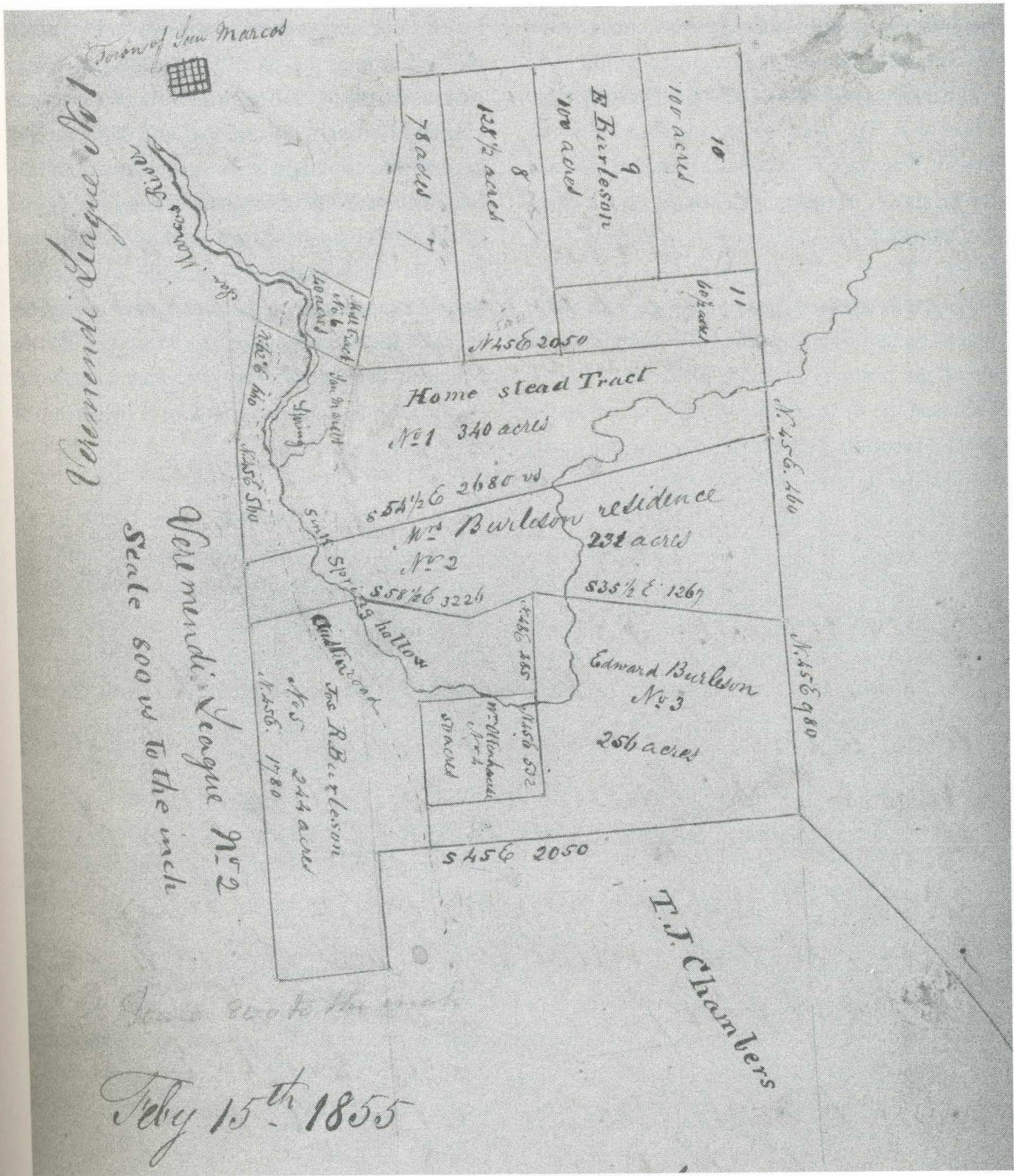

Figure 2-4. 1855 map of San Marcos Springs showing the Homestead Tract, Mrs. Burleson's Residence Tract, the Mill Tract, and the City of San Marcos area. 
construction of the cabin he erected a mill and a dam where the present dam sits. The original dam was about $400 \mathrm{ft}$. long. The eastern section of the dam crossed the channel at a right angle for twothirds of the length. The rest of the dam ran parallel to the right bank of the river, forming a forebay. The dam was a military breastwork construction of wood, soil, and rock and reached a height of 15 $\mathrm{ft}$. The dam created a head of approximately eight to twelve $\mathrm{ft}$. This site, which was then known as the Mill Tract (see Figure 2-4), was used as a saw and gristmill, a cotton gin house, and a press (McGehee 1982).

After the death of General Burleson in 1851, his widow and sons kept the Mill Tract until the sale of the property in 1855 . Fielding L. Rector purchased the 40 -acre tract of land including the saw and gristmill, the cotton gin house, the press, and all other fixtures for $\$ 5,100$ (HCDR C:6). On Feb. 12, 1866, Rector sold the Mill Tract to Thomas Mooney for \$5,000 (HCDR D:560). From this point on the Mill Tract was split and purchased by various individuals for various uses of the land (see Appendix L, Record of Deed Transactions for the Mill Tract). In 1883, Thomas R. Fourgurean and Thomas Code built the first ice factory in San Marcos on the Mill Tract. During this period the Mill Tract was used as an energy source for the community of San Marcos.

On Oct. 12, 1888, the San Marcos Water Company bought controlling interest in the 40 acre tract of land and used the land and buildings as a water supply for the community of San Marcos, but kept the ice factory as a functioning unit. In 1889, the San Marcos Water Company expanded their interest in the land and bought an additional interest in the Mill Tract.
In 1894 new modern ice-making equipment was installed and new management took over the operations of the ice plant. During this period the grist and sawmill were still in working order on the right bank of the river just below the dam. On the left bank of the river an electric light-works facility was in operation as well. Around the turn of the century the Mill Tract changed hands various times until 1909 when the San Marcos Utilities Company bought the land from the San Marcos Electric Light \& Power Company and the San Marcos Water Company. During the period of numerous ownerships the buildings and the twothirds of one acre they sat on were leased to the San Marcos Ice Company and used as an ice factory for fifty years. San Marcos Utilities occupied the land for sixteen years until Texas Public Utilities Company took over ownership of the buildings in 1925 .

A. B. Rogers became a key figure in the ownership of the Mill Tract in 1926 when he purchased the undeveloped acreage of the tract and the Homestead Tract from the San Marcos Utilities Company for $\$ 21,466$ (HCDR 91:458). During this same year the ownership of the dam and buildings on the Mill Tract changed hands again from the Texas Public Utilities Company to the Texas Power \& Light Corporation (HCDR 92:591). In 1927 the sale and manufacturing of ice became the only functional operation on the Mill Tract.

In 1939 several substation properties around Texas were transferred to the Lower Colorado River Authority (LCRA). One property transferred at that time consisted of buildings on the Mill Tract that was purchased from the Texas Power \& Light Corporation. In the late 1940s Paul Rogers, son of A. B. Rogers, began to equip Aquarena Springs with larger facilities and to purchase more land. 
At that time he purchased the 107.3 acres from his father (HCDR 144:330). In 1956 Paul Rogers bought the dam from the LCRA for an undisclosed amount (HCDR 168:383).

In 1958 the Southland Ice Company purchased the ice plant for manufacturing ice. During the 1960s ice production rose to its highest level and progressed enough to produce 40 to 45 tons per day. In 1976 the ice factory was permanently closed due to the introduction of electric refrigerators and party ice. In 1977 the remains of the Mill Tract, including the ice plant, were sold to Aquarena Springs. Five years later, in 1982, Aquarena Springs opened a restaurant occupying part of the boiler room and pump house of the old buildings on the property. This restaurant was named "Pepper's on the Falls." Southwest Texas State University (now Texas State University-San Marcos) bought the property with the purchase of Aquarena Springs in 1994 and kept the restaurant running for a short period. Landry's Corporation then began renting the restaurant buildings where they established the present-day Joe's Crab Shack.

\section{History of the Burleson Cabin}

\section{The Original Structure}

There are various old photographs and Augusta Koch's bird's-eye view map (Figure 25) that illustrate the postition and condition of the cabin. The bird's-eye view map illustrates a single

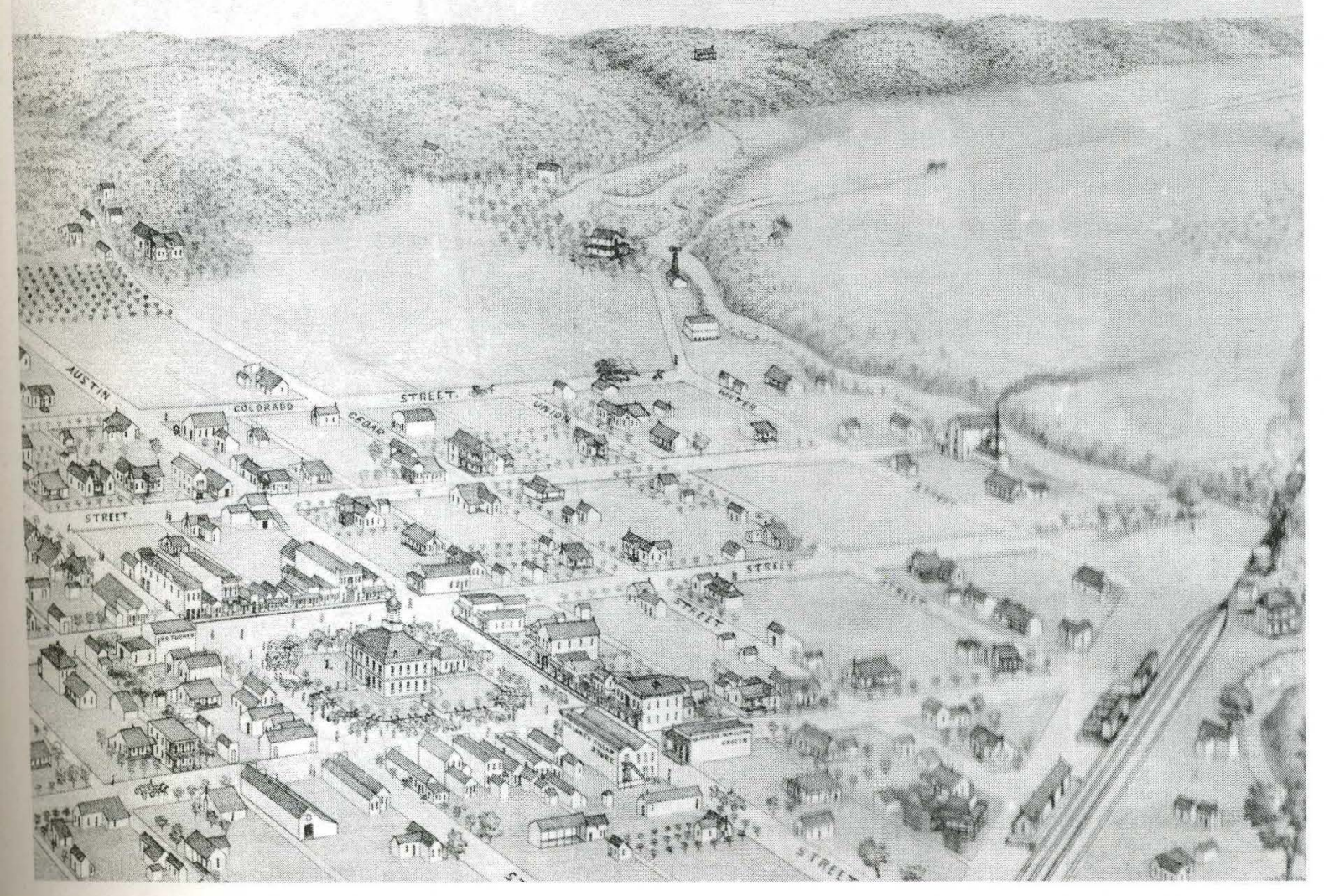

Figure 2-5. Augusta Koch's bird's-eye view map of the San Marcos area. 
cabin on the edge of the escarpment above the San Marcos Springs.

One photograph shows the log cabin on the crest of the ridge overlooking the springs (Figure $2-6)$. Figure 2-7, taken in 1907, shows the cabin from a spot further upstream where an outbuilding is visible. In the photograph, the vegetation is cleared, where today thick brush and tall trees grow. In Figure 2-7 there is an apparent outbuilding under a tree to the right of the house. It is unclear if this outbuilding was the school Burleson built for his children or was erected later for another purpose.

Five other pictures showing greater detail were taken closer to the cabin. These photographs have been put in chronological order using the condition of the structure, and known dates. The first photograph (Figure 2-8) is from a postcard with a 1908 postmark. This is one of the few pictures showing the cabin's south and west sides. The outbuilding is present in the photograph and is located due north of the west wall of the cabin and perpendicular to the cabin's long axis (Tula Wyatt Collection, San Marcos Public Library [TWC SMPL]).

The second photograph (Figure 2-9) illustrates that the porch was enclosed on the northwest side at some later date than the original construction. Note the board propping the wall. This photograph was published in the San Antonio Light newspaper on March 12, 1911.

The third photograph (Figure 2-10), shows the north and east sides of the cabin, clearly illustrating the original chimney before it collapsed. Most of the wood siding had fallen off the east wall of the northern crib, and at least one of the north wall logs, east of the chimney, had dislodged. There appears to be a bedrock feature or a low stone wall on the eastern side of the cabin. Apparently the cabin was abandoned at the time of this picture.

The fourth photograph (Figure 2-11) shows a group of people standing on the east side of the cabin. The photograph shows that the two crib doors had been enclosed as windows. The dogtrot breezeway had been enclosed, though the door is missing, and most of the wood siding had fallen off.

The fifth and final photograph published in the San Antonio Express newspaper April 11, 1915, illustrates the cabin in ruins (Figure 2-12). The roof and chimney have collapsed, and the doors are missing. The west porch has collapsed entirely, and more logs have fallen out of the north wall, east of the chimney.

In 1917 the structure collapsed in a heavy rainstorm and fell to a "mass of debris" ("Historical Survey Group to Have Medallion on Burleson Homestead," SMR 19 May 1966: TWC SMPL). In 1932 the Daughters of the Republic of Texas (DRT) erected a monument at the site (Figure 2-13). The monument was carved on Texas gray granite and mounted in stones collected from the original fireplace ("Burleson Homestead Marker Was Dedicated Here Last Thursday" by Renick F. Ansell, SMR 8 July 1932: TWC SMPL). This monument was later moved.

Sometime before 1960, Paul Rogers decided to tear down the original cabin to insure the safety of children living around the area. In the process of tearing down the structure, all of the salvageable logs and stones were numbered and labeled for a future reconstruction of the cabin. The entire structure was dismantled, including the 


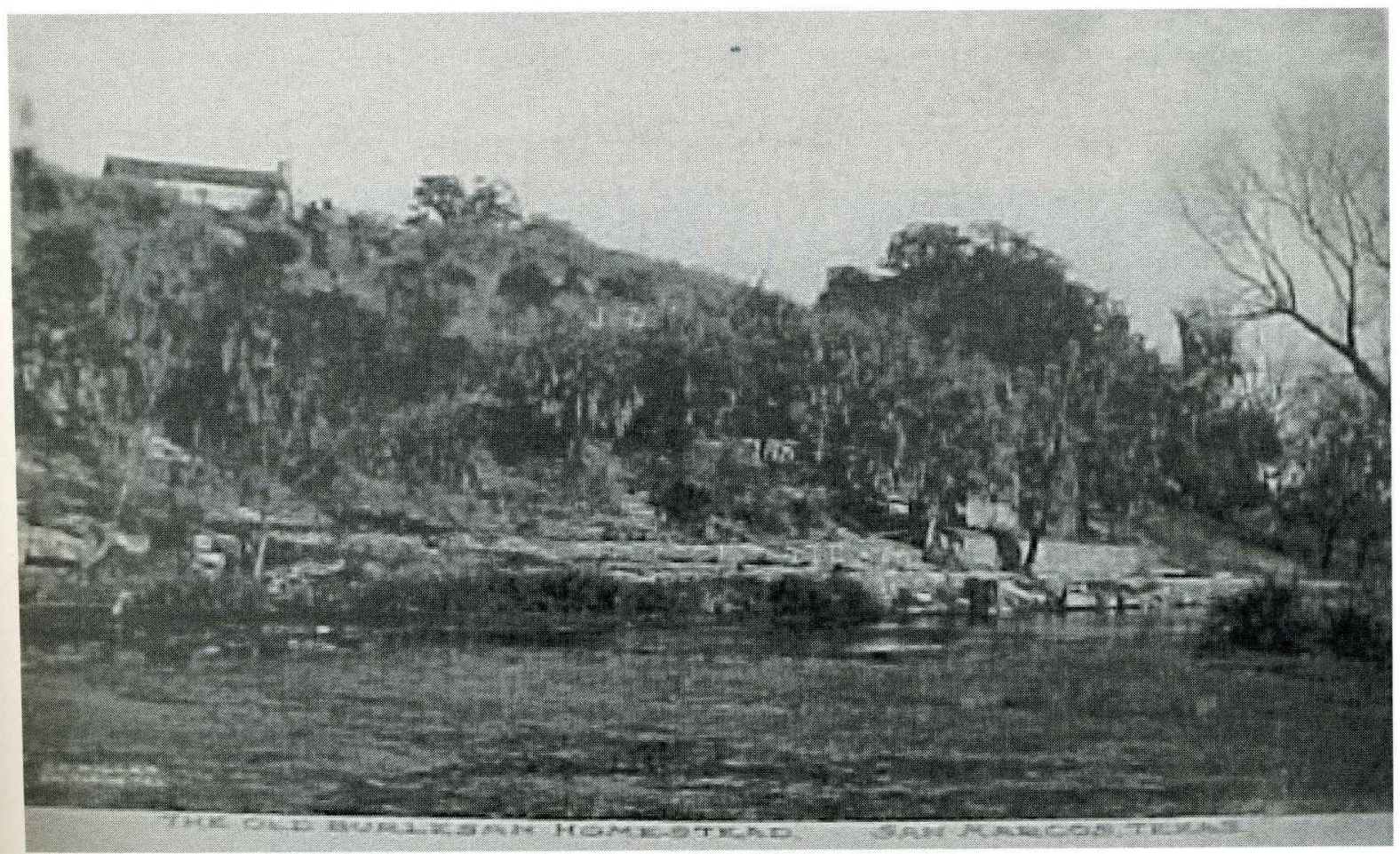

Figure 2-6. The Burleson cabin is shown on the crest of the ridge (date unknown).

avy
is"
i on
WC
c of
site
sxas
rom
ead
'by
PL)

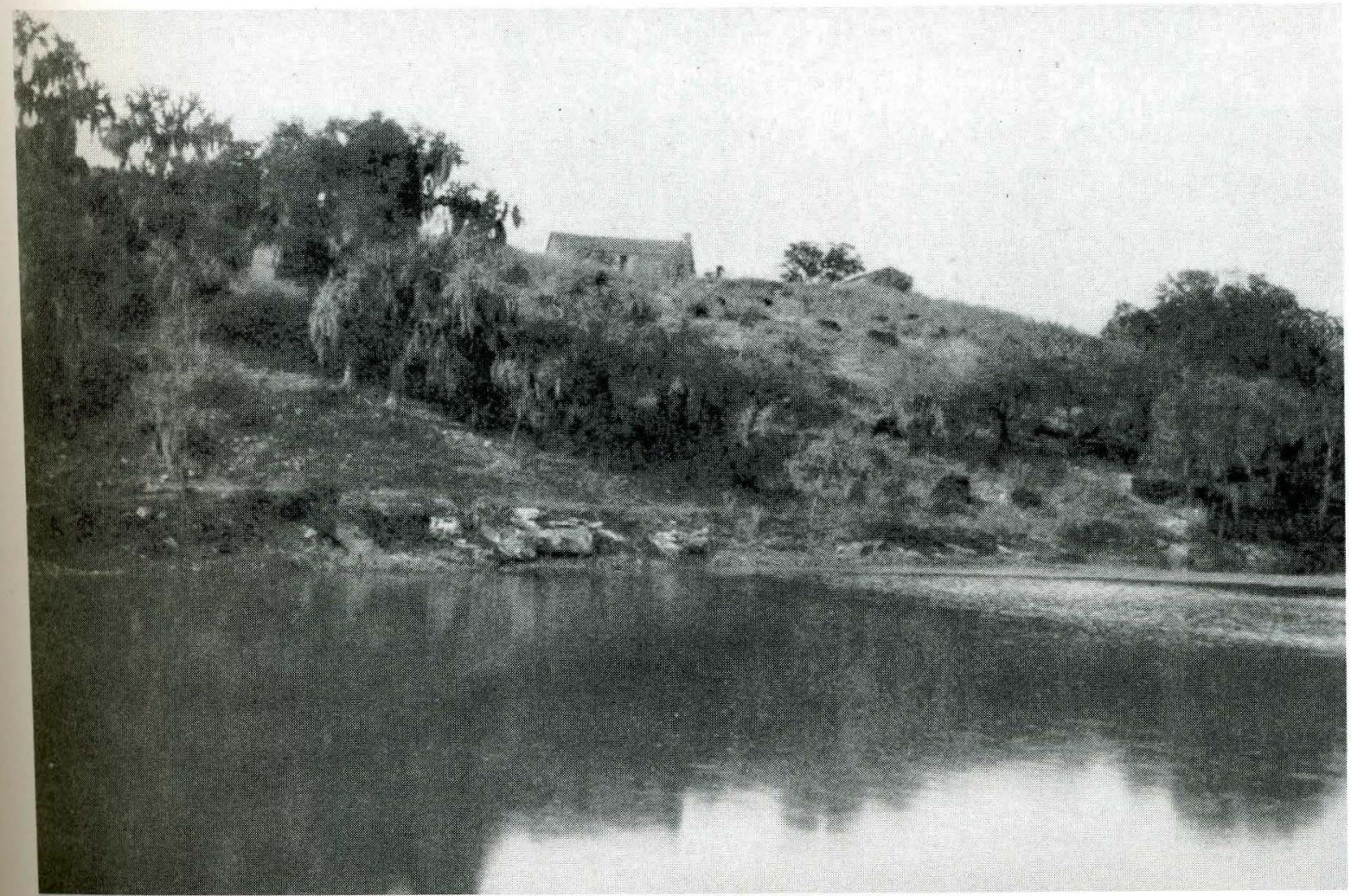

Figure 2-7. Photograph taken in 1907 showing the San Marcos River, Burleson's home, and an outbuilding. (Photo reproduced from the San Marcos-Hays County Collection at the San Marcos Public Library.) 


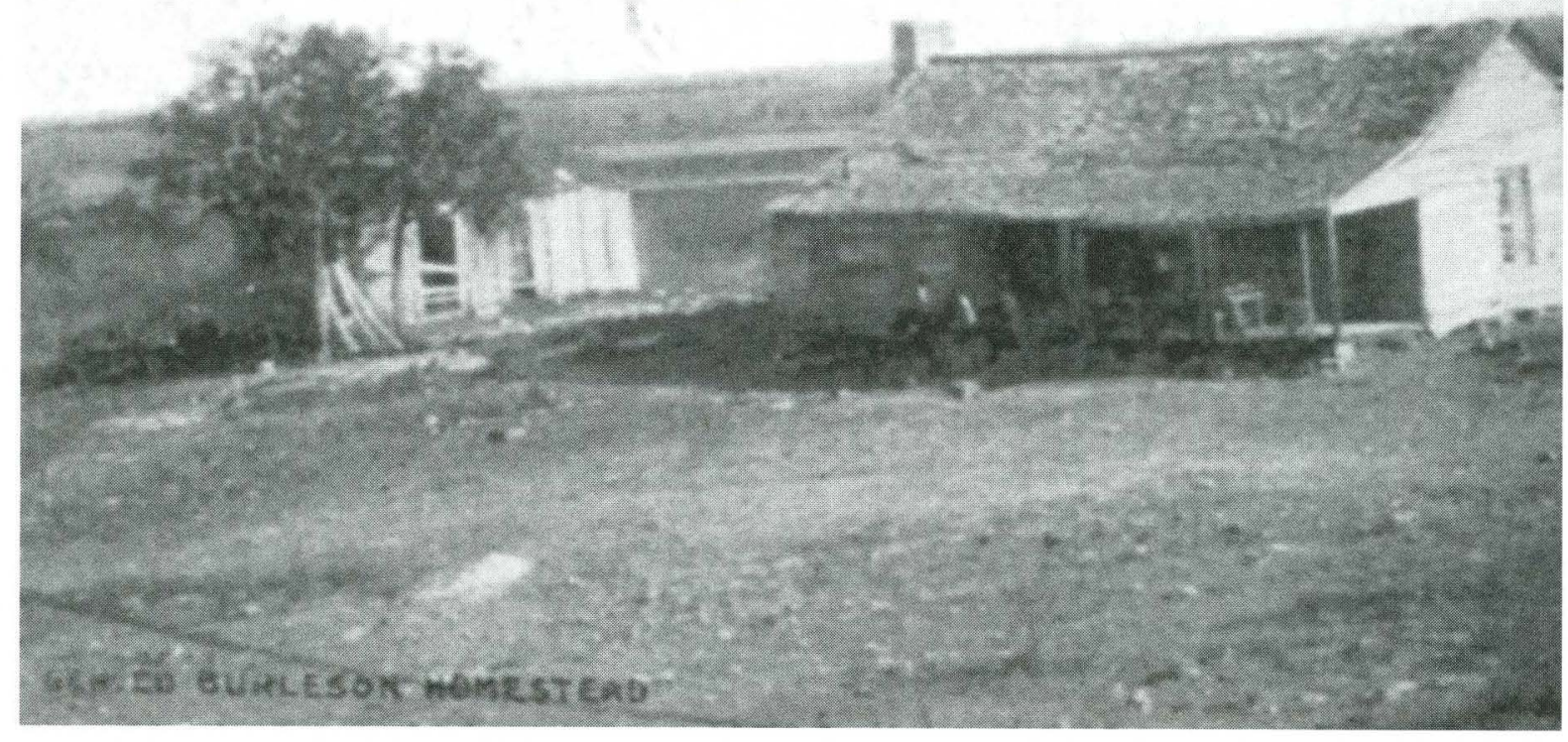

Figure 2-8. Postcard with a 1908 postmark, showing the old Burleson cabin.

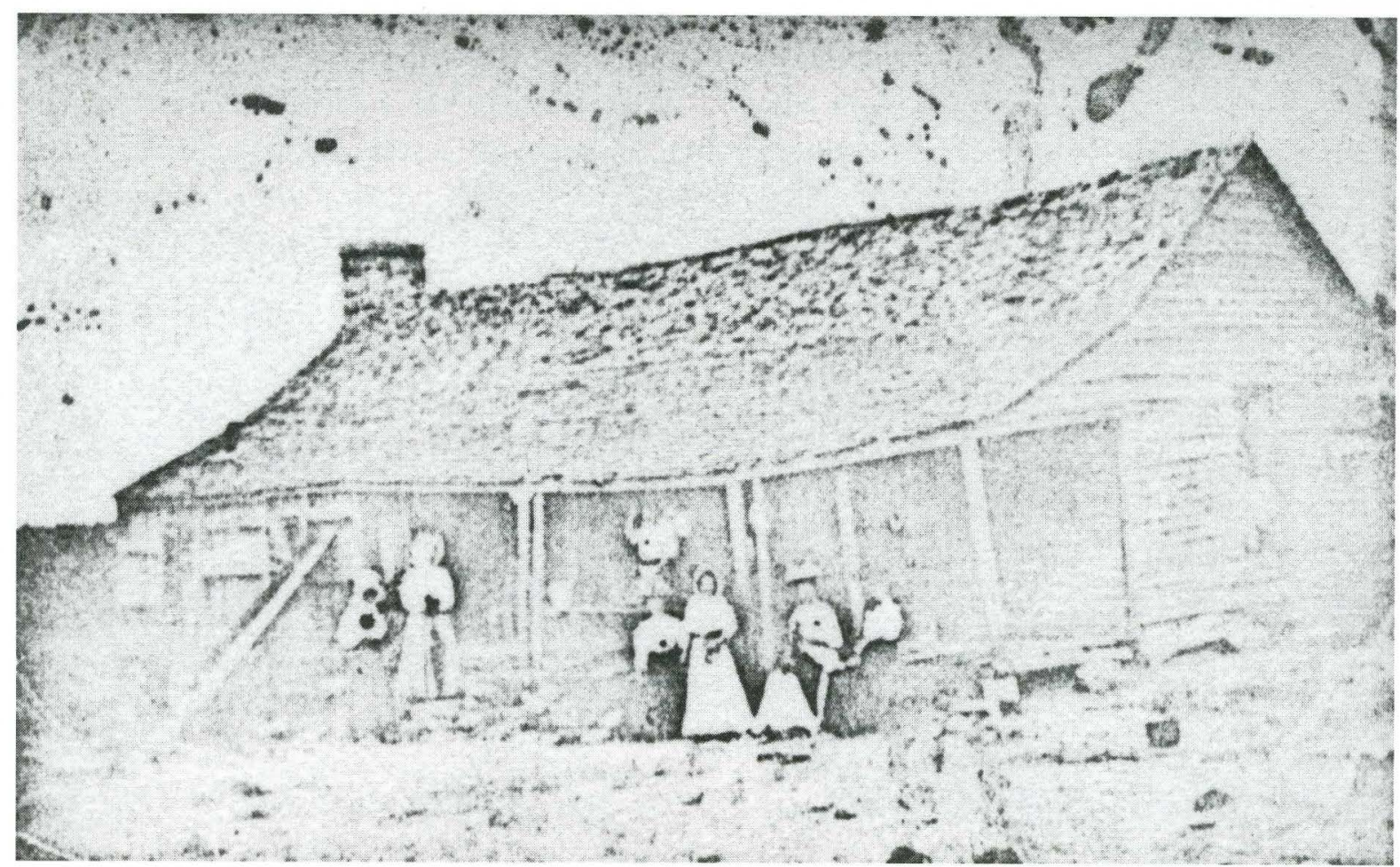

Figure 2-9. Photograph dated March 12, 1911 illustrating the enclosed porch on the northwest side of the old Burleson cabin. 


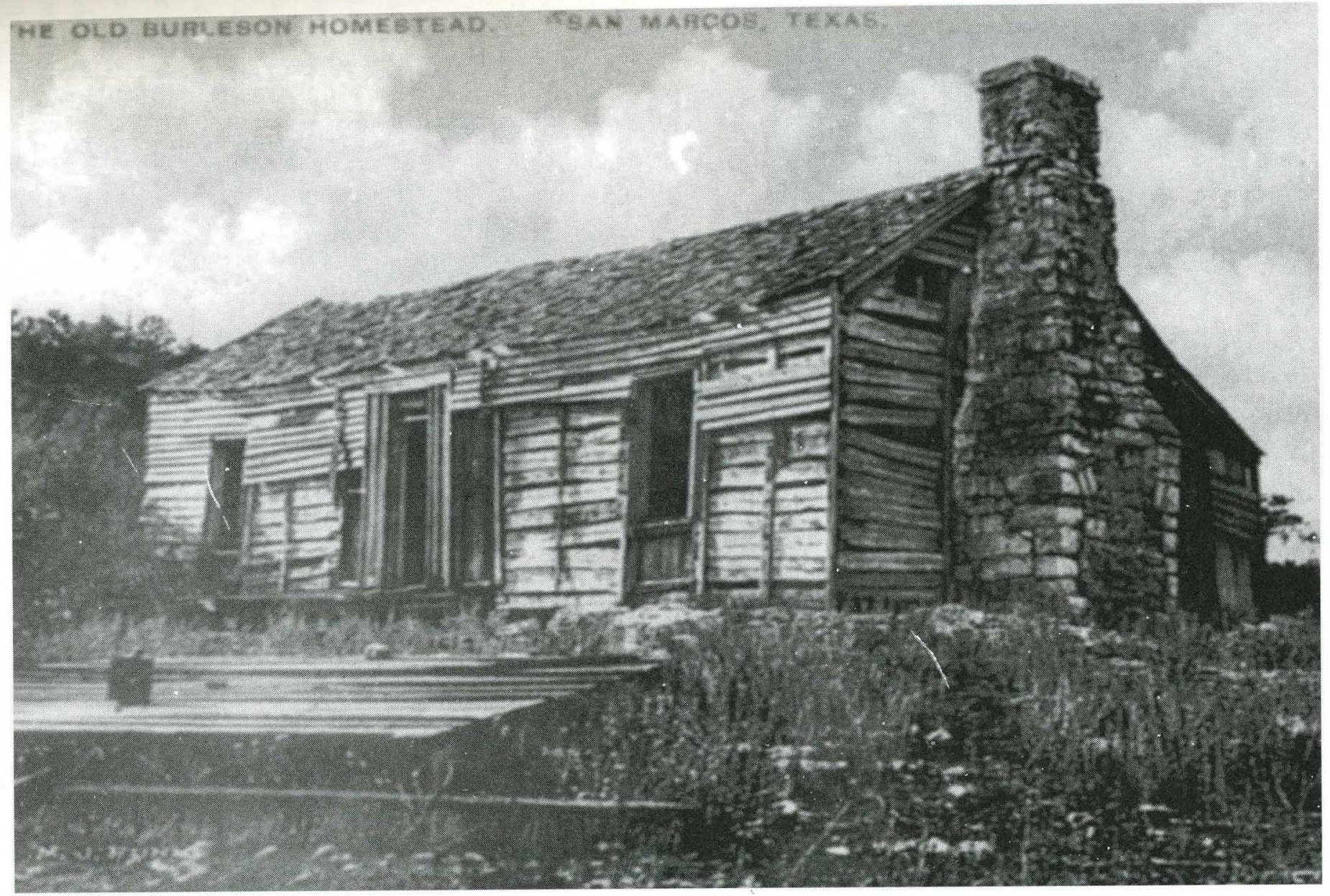

Figure 2-10. The north and east sides of the Burleson cabin, showing the original chimney before its collapse. 


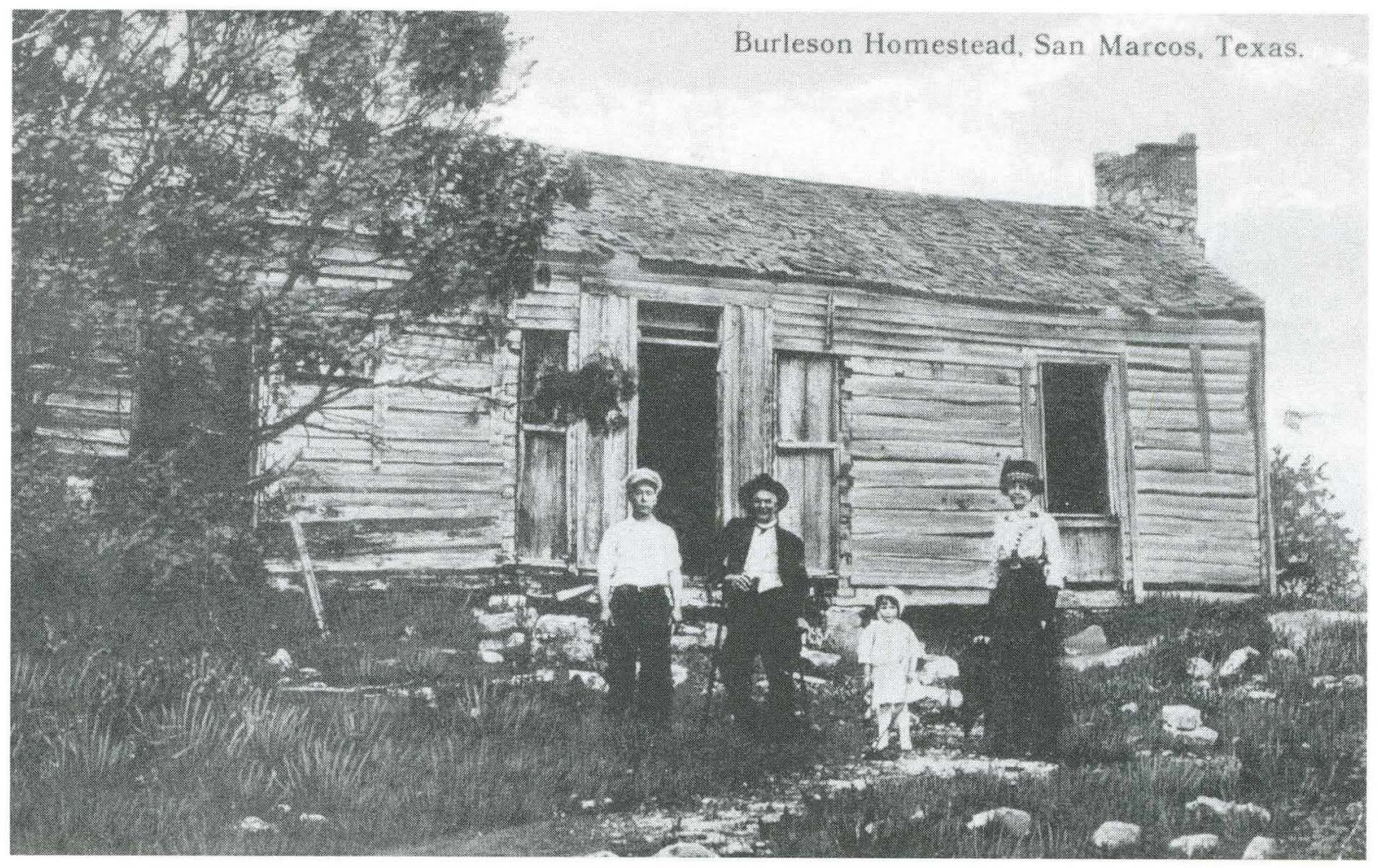

Figure 2-11. The Burleson cabin's east side, showing the enclosed dogtrot.

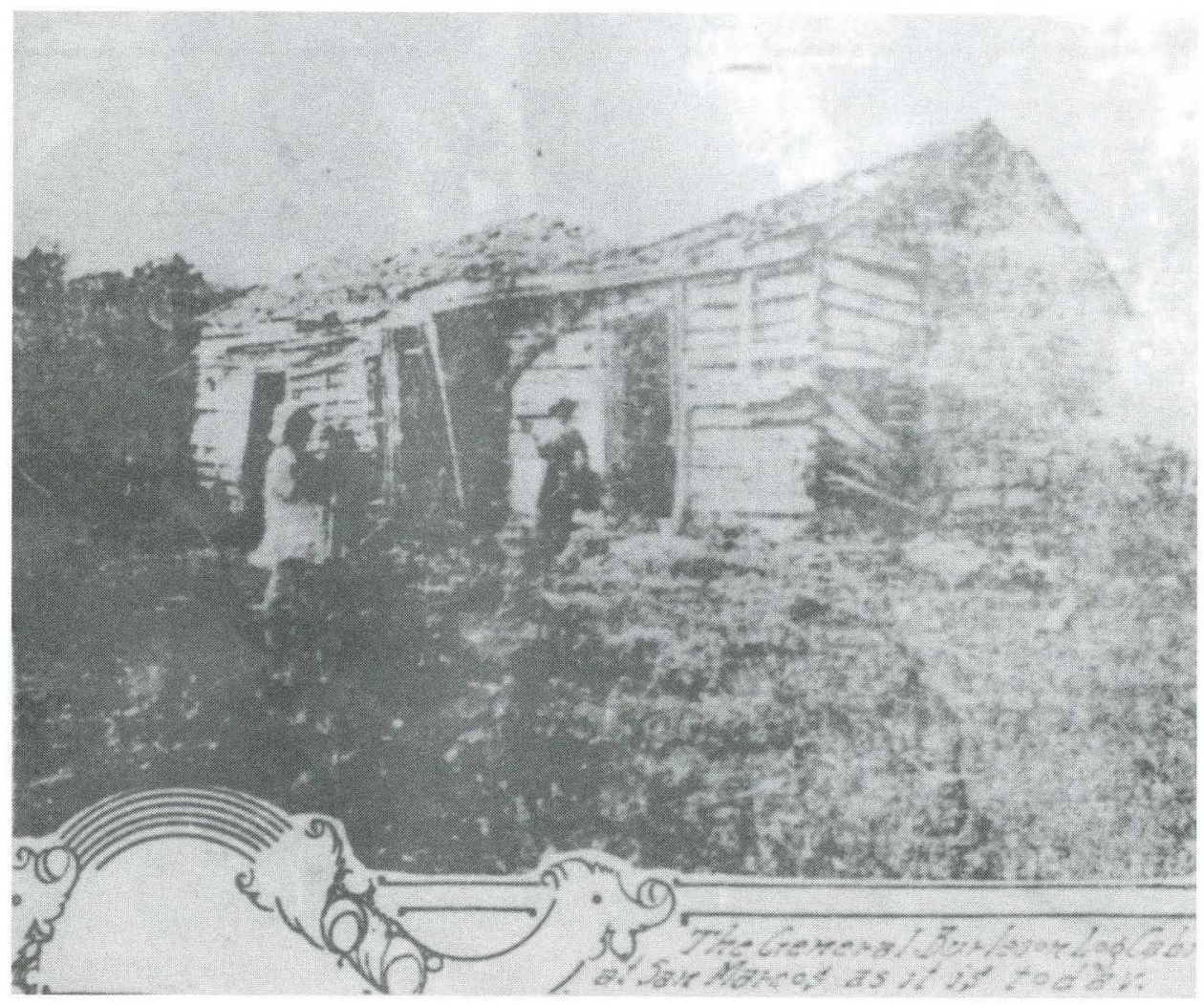

Figure 2-12. Photograph of the Burleson cabin in ruins, published in the April 11, 1915 San Antonio Express. 
foundation stones and the chimney. During this time there were remnants of an 8-x-8-ft. outbuilding, but it was dilapidated and nothing was salvageable (Isabel Gutierrez, personal communication 2000).

In 1960 the Sky Ride gondola station was constructed on the original site of the cabin (Figure 2-14). In 1964, Paul Rogers moved the DRT monument from its original location on the west side of the cabin facing Edward J. L. Green Street to the south side of the cabin to make it more visible to visitors (Isabel Gutierrez, personal communication 2000).

\section{The Replica Cabin}

In 1964 Paul Rogers commissioned Jack Warner to reconstruct the cabin in the original location and "as authentically as possible." Rogers consulted Mrs. William A. Wyatt, Sr., who had published a story in 1915 that included plans, a description of the structure, and pictures dating back to 1895 showing how logs fit together, window design, doors, flooring and chimney. Rogers and Warner selected three contemporary $\log$ cabin structures built in the same style as the Burleson cabin to create a replica cabin. With the assistance of Coke Stevenson, Jr., they recovered logs from Governor Coke Stevenson's log home in Llano County. They received logs from the Burnham home in Burnet County, as well. Roof boards and rafters came from the Stringtown Stagecoach Stop, originally owned by James P. Matthews (Figure 2-15).

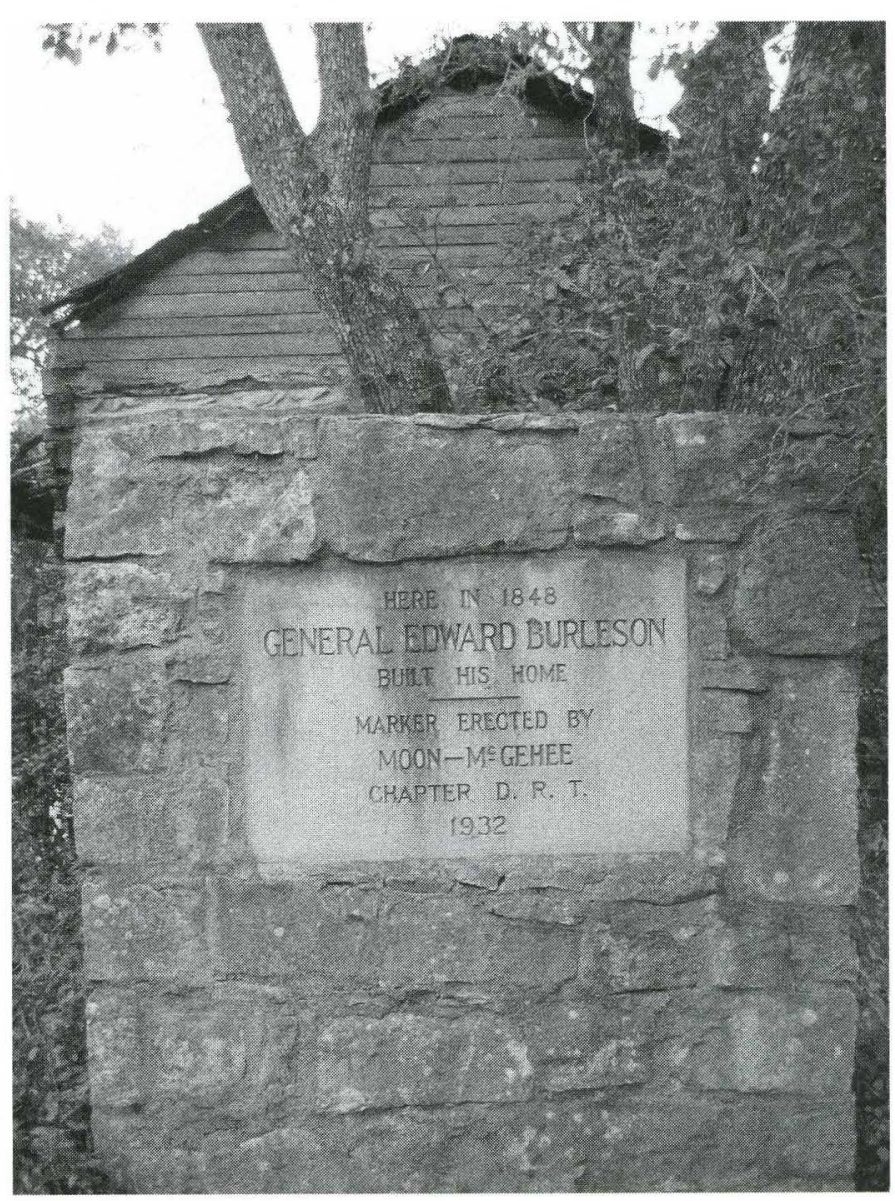

Figure 2-13. The Daughters of the Republic of Texas erected a granite marker at the site of the Burleson cabin in 1932.
Jack Warner and other individuals employed at Aquarena Springs built the replica cabin with two rooms, a dogtrot breezeway, and a wide porch across the west side (Figure 2-16). Some logs from the original structure were also used. Original chimney stones were reused to construct the chimney and fireplace (Isabel Gutierrez, personal communication 2000). Square nails, purchased in Indiana and shipped to a store near Blanco, were used in the replica, as would likely have been used in the original construction.

The intention of Paul Rogers was to build a replica cabin of General Edward Burleson's home as authentically as possible and located in the 


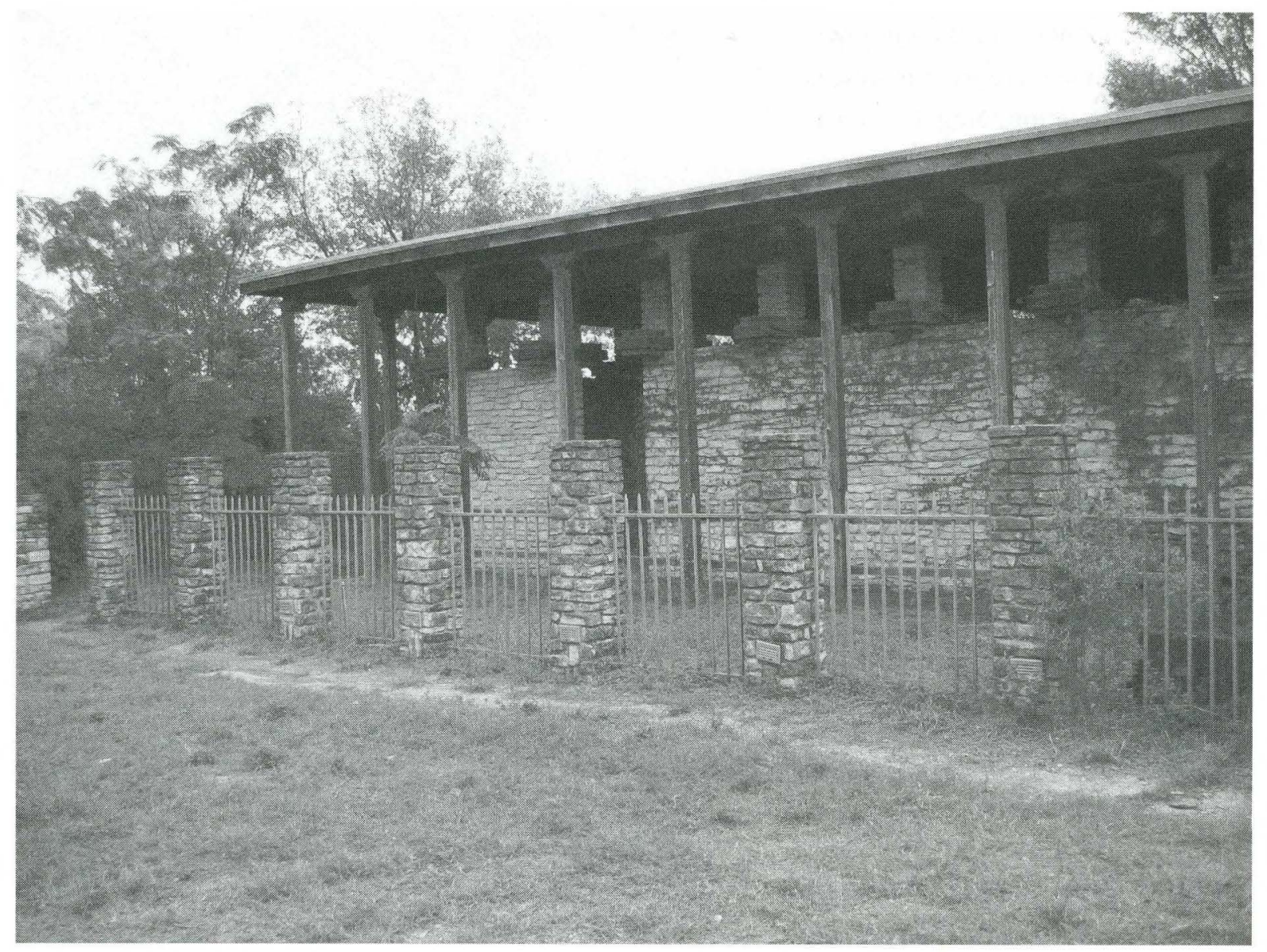

Figure 2-14. A Sky Ride gondola station was erected on the original cabin site in 1960.

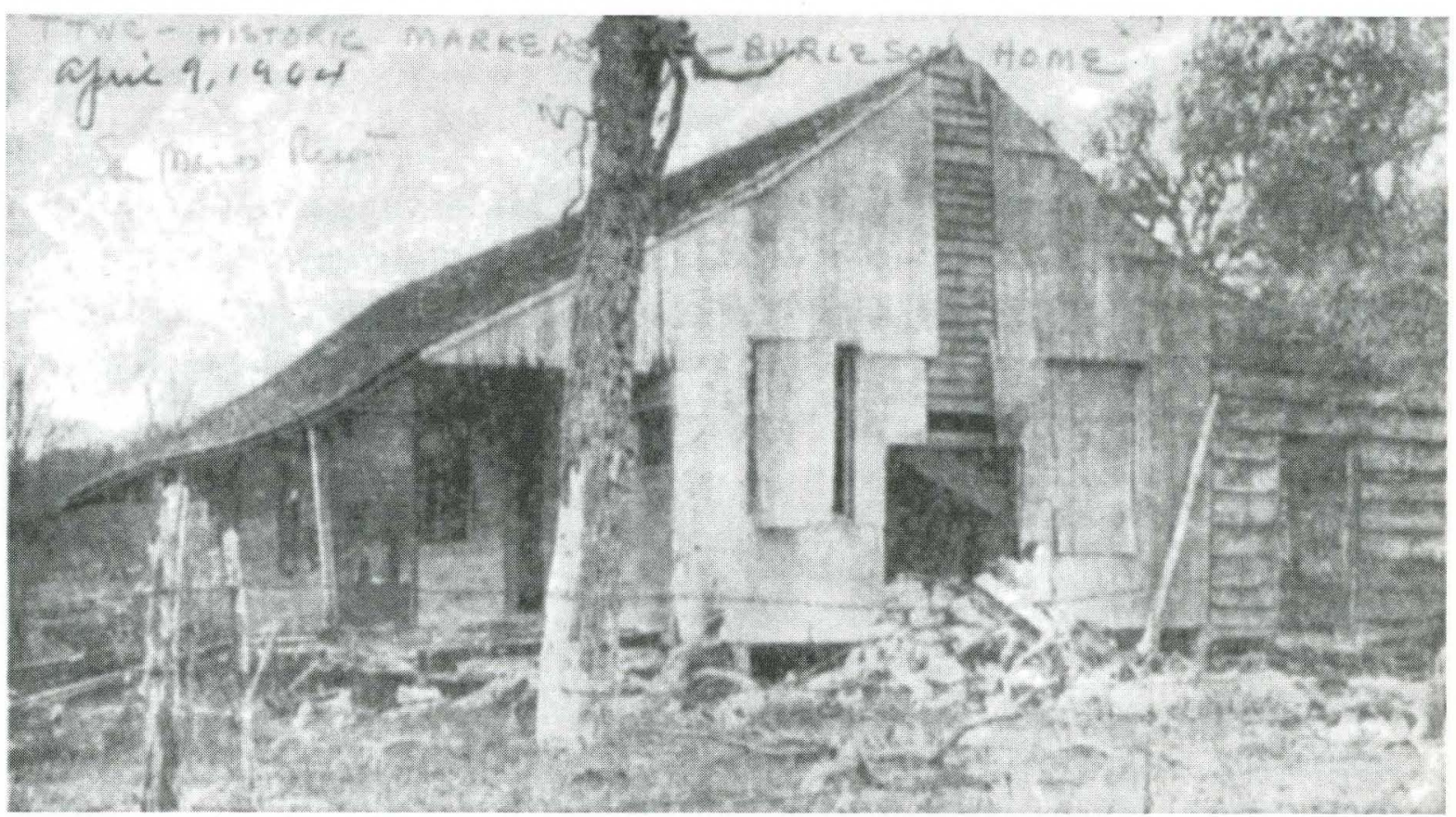

Figure 2-15. Logs were used from structures contemporaneous with the Burleson cabin, such as the Stringtown Stagecoach Stop, in construction of the replica cabin. 


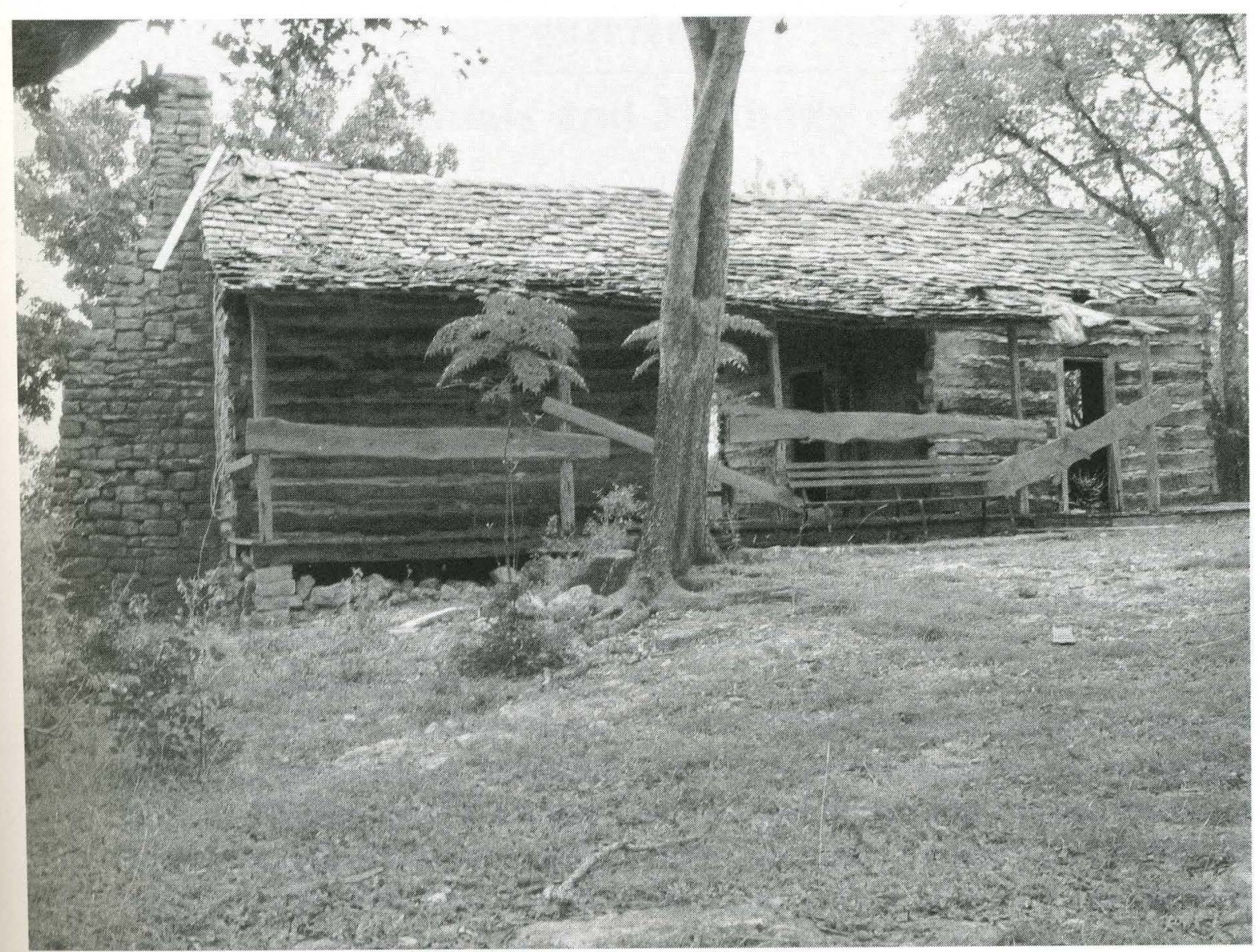

Figure 2-16. The Burleson cabin replica, constructed in 1966.

original position. After the original cabin was dismantled in 1960, the Sky Ride tension staion was constructed in 1962 on the location of the original cabin, making it impossible for the replica to be placed there (Isabel Gutierrez, personal communication 2000). This prompted Paul Rogers to direct the construction of the replica cabin south of the original location and closer to the hillside.

This replica cabin still stands today atop the hill overlooking the springs that create the San Marcos River. The replica was completed in 1966. On April 21, 1967, the Hays County Historical Survey Committee placed a Historical Marker on the replica cabin designating it as a Texas State Historical Site. 


\section{Goals and Methods}

\section{Britt Bousman, Kevin Schubert, and David L. Nickels}

\section{Goals}

In 1848 General Edward Burleson constructed a log cabin on the edge of the Balcones Escarpment overlooking the San Marcos Springs. This structure stood until 1917 when it fell into ruins, and the ruins were completely dismantled in 1960. In 1964 Paul Rogers, owner of Aquarena Springs, commissioned the building of a replica cabin from original materials remaining on the site and construction materials obtained from three other contemporary structures. Today the structure is in need of repair. In December 1999 Volz \& Associates submitted an architectural assessment of the historic buildings at Aquarena Center to Southwest Texas State University in order to provide guidance to SWT in regard to the continuing use and interpretation of the Burleson cabin replica (Volz 1999).

In this report Volz $(1999: 5,8)$ suggests a general strategy with a number of alternative options in regard to the replica. First, Volz (1999:8) suggests a master plan that integrates the preservation strategies of the Burleson replica with the goals of the Texas Rivers Center. Furthermore, Volz (1999:8) suggested that SWT commission a Historic Site/Structure Report that includes a historical analysis, archaeological investigations, measured drawings, architectural analysis, documentation and condition analysis of existing building fabric, and recommendation for future preservation.

Volz (1999:5) suggested four options. The first option is to preserve the replica and interpret it as a 1960 facsimile of the original house. The second option is to remove the 1960 replica and provide interpretive signs adjacent to the existing monument, erected in 1932 by the Daughters of the Republic of Texas. The third option is to remove the replica and interpret the site based on archaeological and historical research. The final option is to remove the replica and accurately reconstruct the original cabin, outbuildings, and landscape.

The archaeological project was designed to assist SWT in deciding which option is the most reasonable. In order to achieve this goal, the archaeological project had a number of goals. The first goal was to determine the original location of Burleson's cabin. The immediate question was did the replica use the original foundation, or was a new foundation built for the replica? Furthermore, if a new foundation was constructed, did they use the original stones from the Burleson cabin? A second goal was to identify the location 
of the outbuildings shown in historic photographs. A third goal was to collect historical and archaeological information that could be used to develop an accurate interpretation of the site and its inhabitants. The methods discussed below were implemented in order to achieve these goals.

\section{Methods}

The archaeological field and lab methods implemented for the excavations of General Edward Burleson's cabin are discussed below. In the field, the first tasks were to determine what areas needed to be cleared of vegetation and determine the placement of the initial units.

A visual inspection of the area around the replica cabin showed that the replica had been placed south of a paved road and a stone-walled gondola station (Figure 3-1). The gondola ride began at a similar station on the other side of Spring Lake below the escarpment, and ended at this point on the ridge overlooking Spring Lake. People could get off at the station and walk around the historic exhibits and rides that Aquarena placed on the ridge top.

Today, the replica sits near the edge of the escarpment on a flat bench that is bounded by a low stone retaining wall on the edge of the escarpment (see Figure 3-1). Recent sediment has been trapped upslope of this wall. A chain-link fence was on the northeast side of the replica perpendicular to the ridge slope. The upslope portion of this bench, between the gondola station and the replica, was scooped out, possibly with a bulldozer, in order to make the bench flatter. In this area, crushed limestone gravel is scattered and moderate-sized bedrock blocks are exposed through the gravel to form a linear pattern that superficially looked like foundation stones (see
Figure 2-11). The scooped fill was then used to create an elevated platform with a stair-step topography further upslope, and the gondola station (see Figures 2-14 and 3-1) sits on this elevated platform. Between the gondola station and the road, the gondola station platform on the northwest side appears to have retained the original slope's configuration, but on the north and northeast sides, the gondola station platform consists of fill.

Previously the Aquarena staff had placed a mock excavation sandbox north of the replica (Figure 3-2). This was a hands-on activity for school tours. The wooden frame of the sandbox was removed and the sand was cleared out by a bobcat front-end loader. This disturbed the surface sediments slightly; however, no features were impacted. Northwest of the sandbox is a recent ceramic dump used in the 1970s (Figure 3-3). Thick vegetation covered the eastern and southern ridge slopes, and this vegetation was removed with hand tools to the fence line.

Areas were designated for excavation because of their likelihood to provide information on the original structure, its foundations, and the outbuilding shown on historic photographs. Once the site had been cleared of all vegetation around the perimeter of the cabin, a grid system was laid out in order to place the excavation units in a systematic alignment. A primary datum was set at the southeast corner of the replica, and the grid was then set in feet and inches parallel to the long axis of the cabin's south wall. A parallel line three ft. south of the cabin's south wall was designated as the base line. All units excavated were aligned with this base line on the grid system. A transit was used to lay out each unit as a 3-x-3-foot unit within this grid system. The English measurement system was used rather than the metric system, 


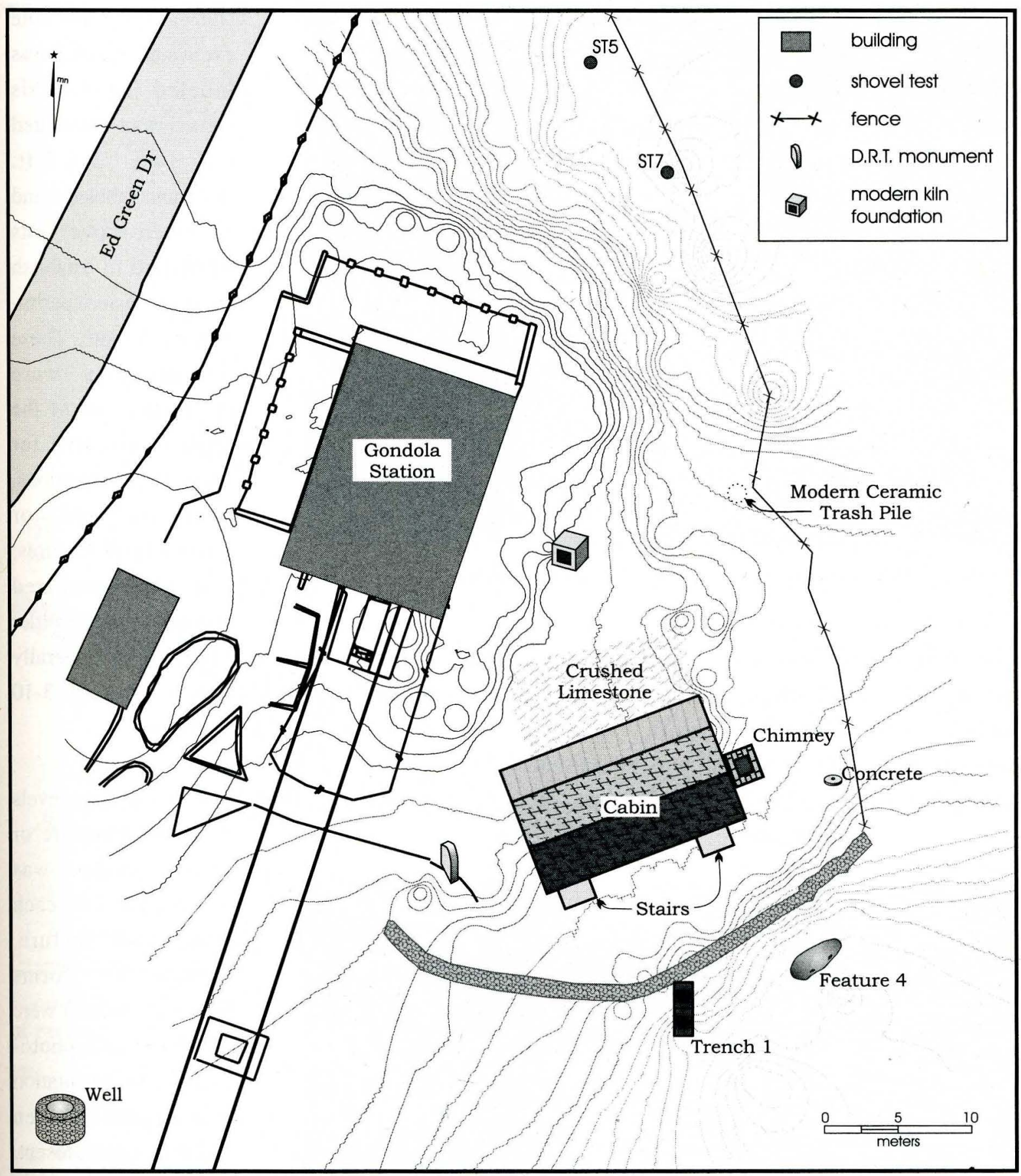

Figure 3-1. Project site map showing Burleson replica cabin and gondola station.

because the occupants used the English system for construction of the cabin itself, and the replica. A trench excavation was placed on the slope of the southern end of the site immediately downslope of the retaining rock wall.
The units were numbered consecutively in Arabic numerals according to the sequence of excavation. Therefore, the first unit excavated was labeled Unit 1, and the others were labeled consecutively through Unit 30 , the last unit 


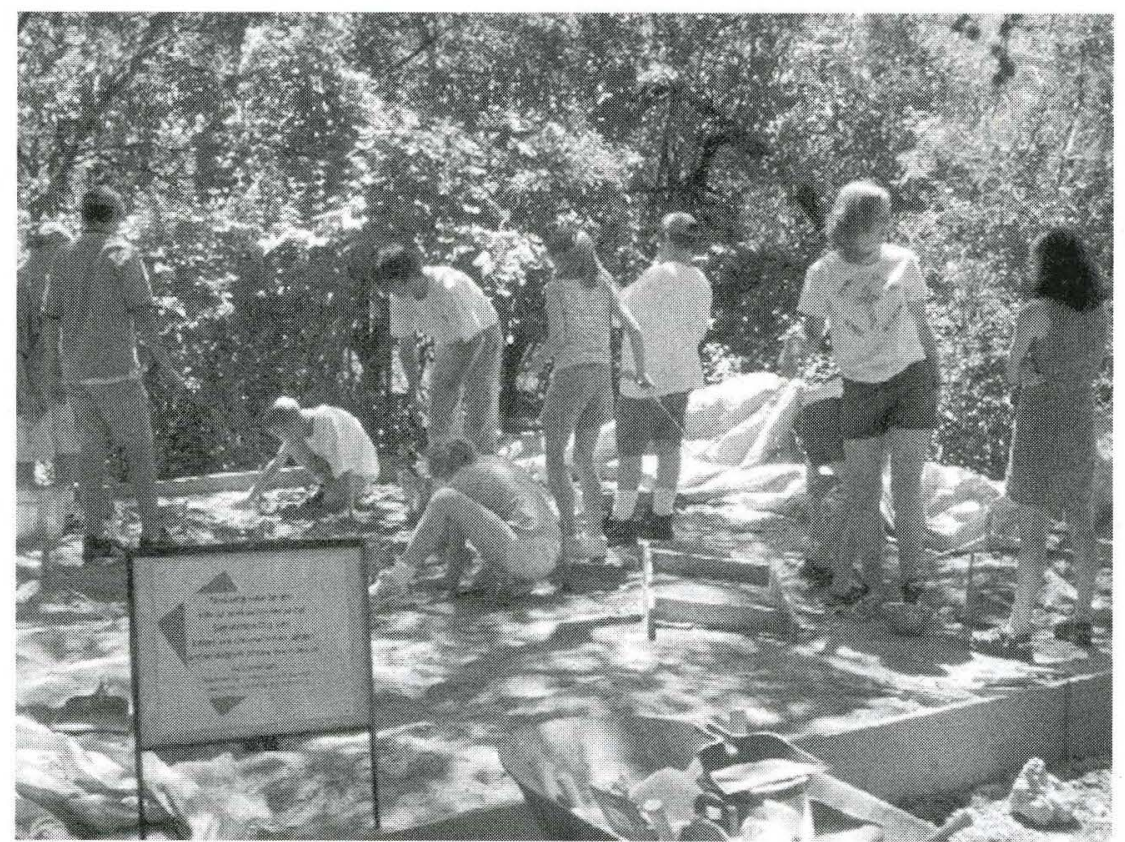

Figure 3-2. Mock excavation sandbox for school tours. there was only one excavated trench, it was labeled TR-1. This trench was excavated on two 3-x-3-ft. quadrants labeled $A$ and B. Seven shovel tests were used to establish the northeastern perimeter of the site. These shovel tests were excavated east of the replica to search for artifact concentrations, trash middens, or architectural features, and were numbered according to the order

excavated (Figure 3-4). Units were placed to identify architecture, determine the context of the replica's foundation, explore artifact concentrations, and to investigate a bedrock feature discovered on the escarpment slope. As

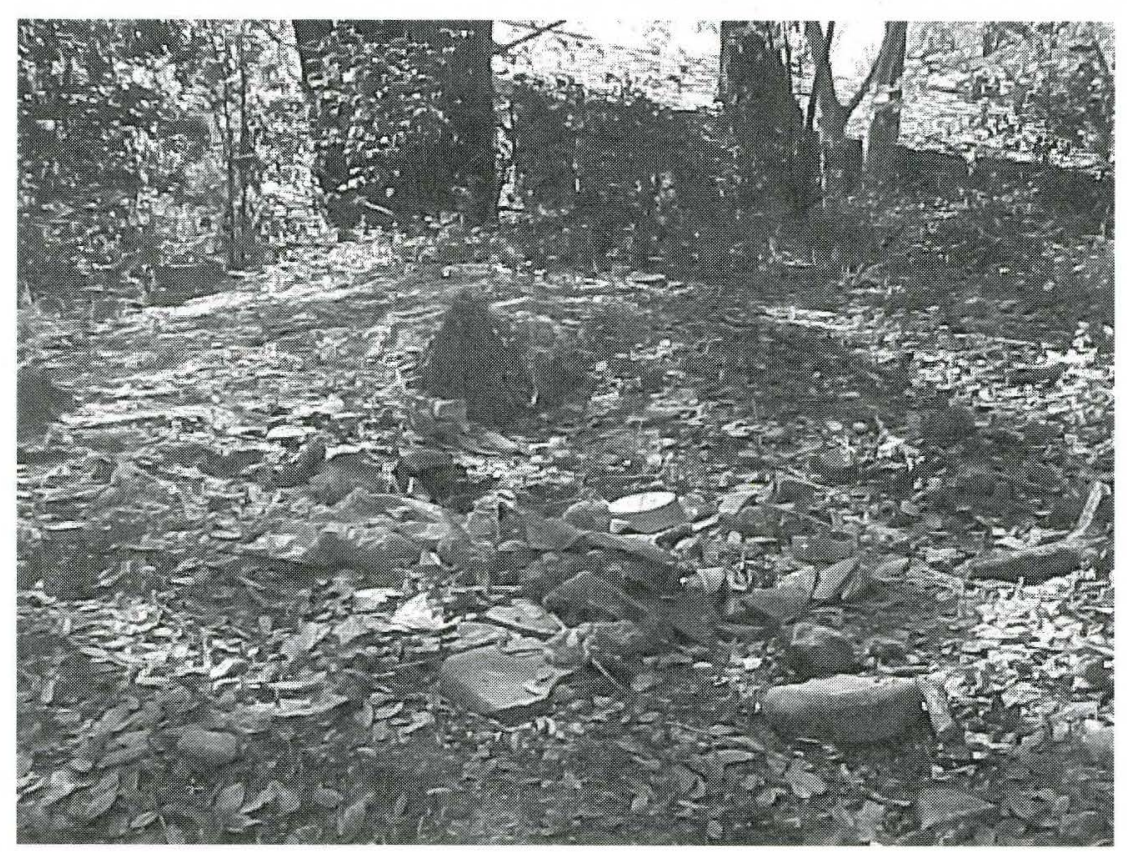
they were excavated. The units were generally excavated in groups; Figures 3-5 through 3-10 illustrate the layout of these groups.

Units were excavated in 8-in. arbitrary levels or when a feature or soil change was uncovered. For each level and feature, appropriate forms (level or feature) were filled out and photographic documentation was made. When features were present, the unit was mapped, and fully recorded by the excavators. A site map was produced that included all units and the replica cabin.

Figure 3-3. 1970s-era ceramic dump. 


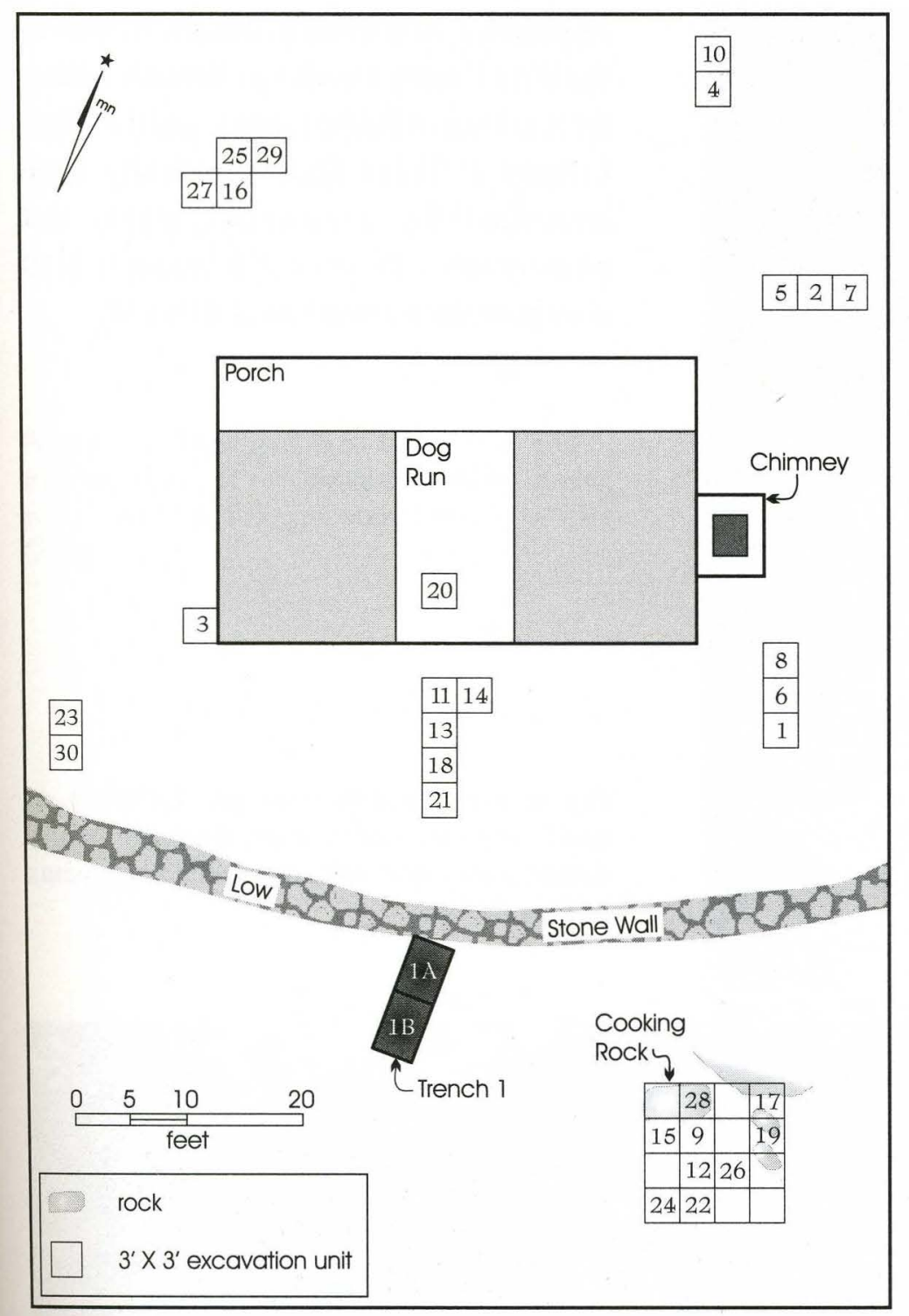

Figure 3-4. Project site map showing cabin replica and locations of excavation units and trenches.

The feature forms, level forms, maps, photo $\log$, and notes were all documented on acid-free paper using a No. 2 pencil.

During excavation, each excavator and staff member kept a field notebook, and notes were recorded on artifact concentrations, features, soil changes (color, texture, firmness), or any significant aspect of the excavated unit. In the field, artifacts were bagged and labeled according to the unit and level in which they were excavated. All sediment matrices extracted during excavations were carefully screened through quarter-inch hardware cloth. Once the field season ended, the excavation units were backfilled with screened sediment.

In the laboratory, all collected artifacts were washed, sorted into basic artifact classes (ceramics, metal objects, lithics, glass, etc.), and bagged in plastic ziplock bags with a catalog sheet inside each bag. A spreadsheet was then developed to record the laboratory analysis sheets. This was implemented in order to obtain correct counts of different artifacts and their placements within the site. Once the artifacts were identified and catalogued they were bagged, boxed, and curated in the Texas State University Center for Archaeological Studies laboratory.

After the excavation was finished, a concerted effort was made to identify and locate any individuals that might have worked at Aquarena Springs and been involved in the construction of the replica cabin. An individual was located, Mr. Isabel Gutierrez, Sr., and a detailed interview was granted. This interview was recorded on tape and fully transcribed. The transcription is provided in 


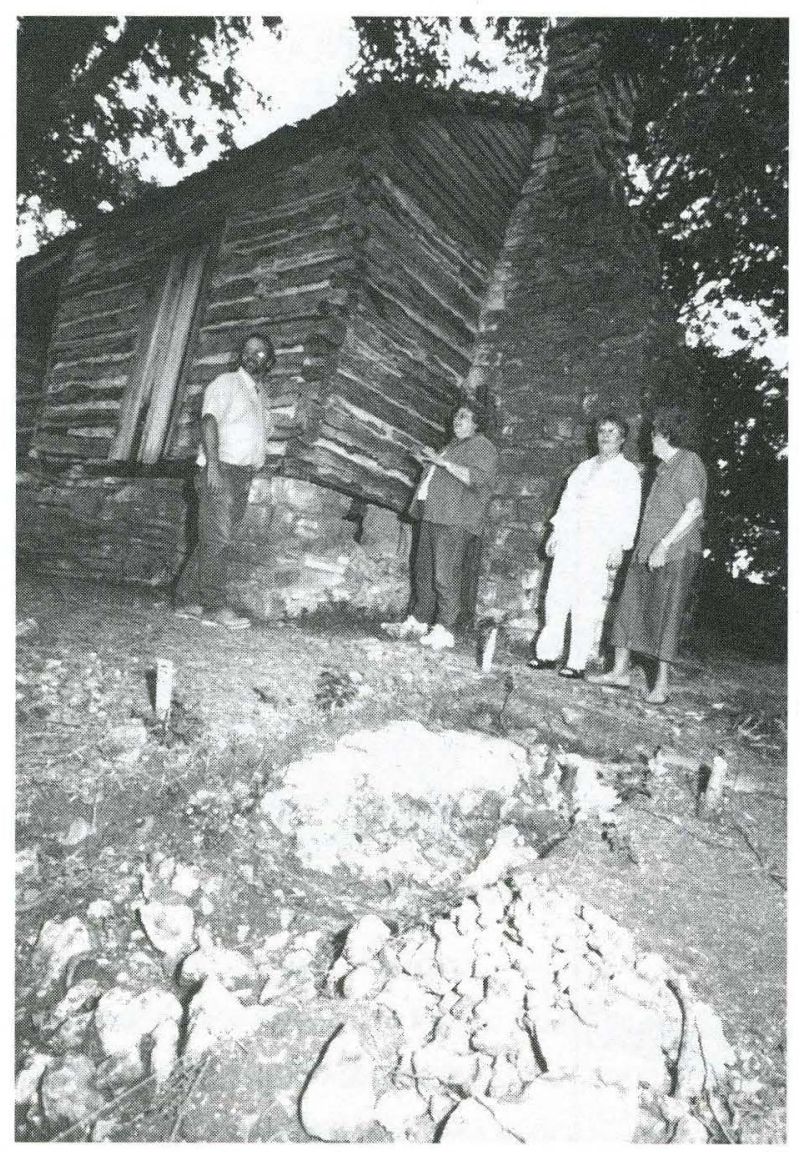

Appendix J. Additionally, historic records in the Hays County Deeds and Records Office, the San Marcos Public Library, and the Alkek Library at Texas State University were consulted for documents, maps, and photographs. Figures 3-5 through 3-10 document the excavations at $41 \mathrm{HY} 37$.

Figure 3-5 (left). Photograph of Units 1, 6, and 8 , with members of the Burleson family during a site tour. (Photograph compliments of Ron Coley)

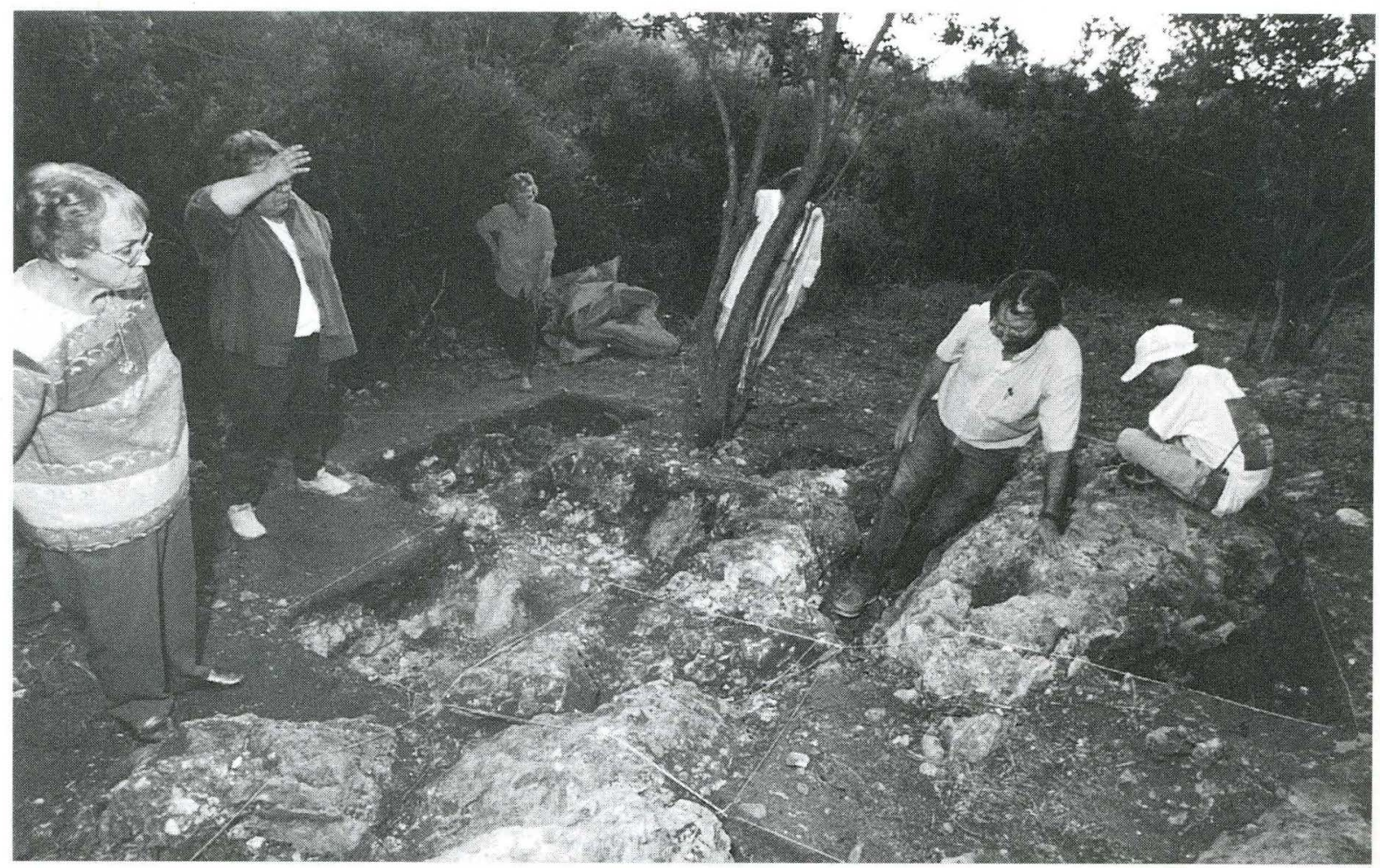

Figure 3-6. Photograph of Units 9, 12, 15, 17, 19, 22, 24, 26, and 28 at Feature 4 with members of the Burleson family during a site tour. (Photograph compliments of Ron Coley) 
Figure 3-7. Photograph of Units 7, 2, and 5, with members of the Burleson family during a site tour. (Photograph compliments of Ron Coley)

Figure 3-8. Photograph of Units 4 and 10, with members of the Burleson family during a site tour. (Photograph compliments of Ron Coley)
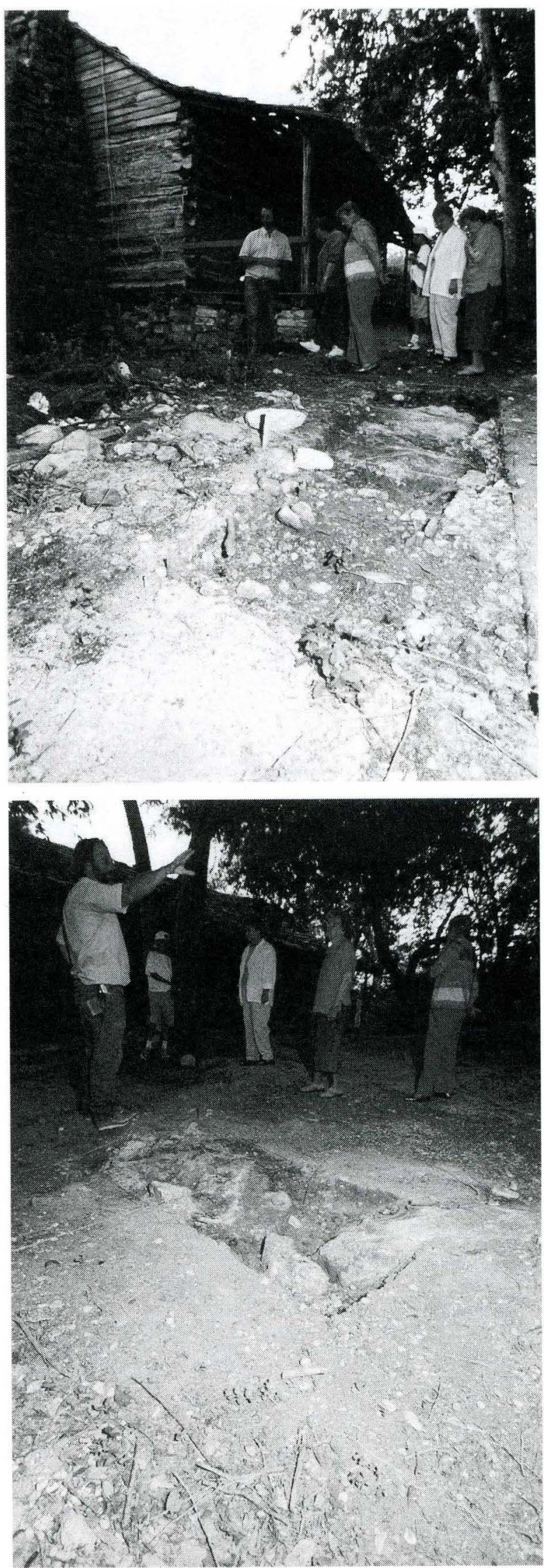

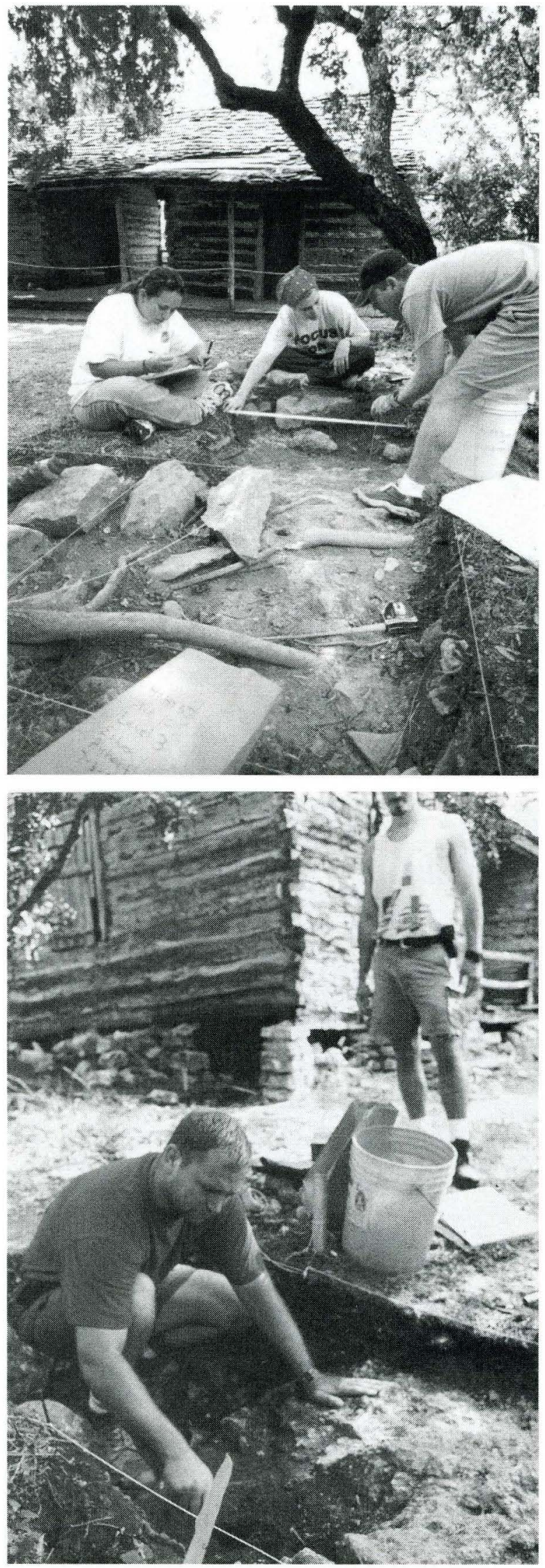

Figure 3-9. Units 16, 25, 27, and 29, with student crew. (Photograph compliments of Ron Coley)
Figure 3-10. Units 23 and 30 with student crew. Unit 3 in background at cabin corner. (Photograph compliments of Ron Coley) 


\section{Chapter 4}

\section{Results of the Archaeological Investigations}

\section{David L. Nickels, C. Britt Bousman, and Barbara A. Meissner}

\section{Archaeological Investigations}

\section{Feature Descriptions}

David L. Nickels

The eight features recorded during the excavations (Table 4-1) are described in this section. Readers are referred to the site map (see Figure 3-4) for Unit and Feature locations.

\section{Feature 1}

Feature 1 is a concentration of dark brown to black ashy soil with charcoal, chert flakes, and firecracked limestone encountered in the southern portion of Trench 1A, and the northern portion of
Trench 1B (Figure 4-1). The midden debris was lying under 2 to 3 inches of light brown sandy loam, and because of the undulating bedrock on which they were setting, ranged from 3 to 12 in. in depth. Limited exposure within the trenches revealed that the concentration covered an area of approximately $6 \mathrm{ft}$. north-south, and at least 3 ft. east-west. Historic ceramics, nails, glass, and other metal were also found within the ashy midden matrix, indicating that the cultural remains are mixed, and thus retain little or no integrity.

\section{Feature 2}

Feature 2 is a large, flat limestone slab broken into many pieces but still somewhat articulated,

Table 4-1. Features encountered during the excavations.

\begin{tabular}{|c|c|c|}
\hline Feature & Description & Unit(s) \\
\hline 1 & Firecracked Rock Concentration & Trenches 1A, 1B \\
\hline 2 & Articulated Bedrock Slab & 2 \\
\hline 3 & Firecracked Rock Concentration & $1,6,8$ \\
\hline 4 & Hand-hewn Bedrock & $9,15,28$ \\
\hline 5 & Firecracked Rock Concentration & $11,13,14$ \\
\hline 6 & Concrete/Caliche Concentration & 18,21 \\
\hline 7 & Limestone Slabs & 18,21 \\
\hline 8 & Firecracked Rock Concentration & 16,25 \\
\hline
\end{tabular}




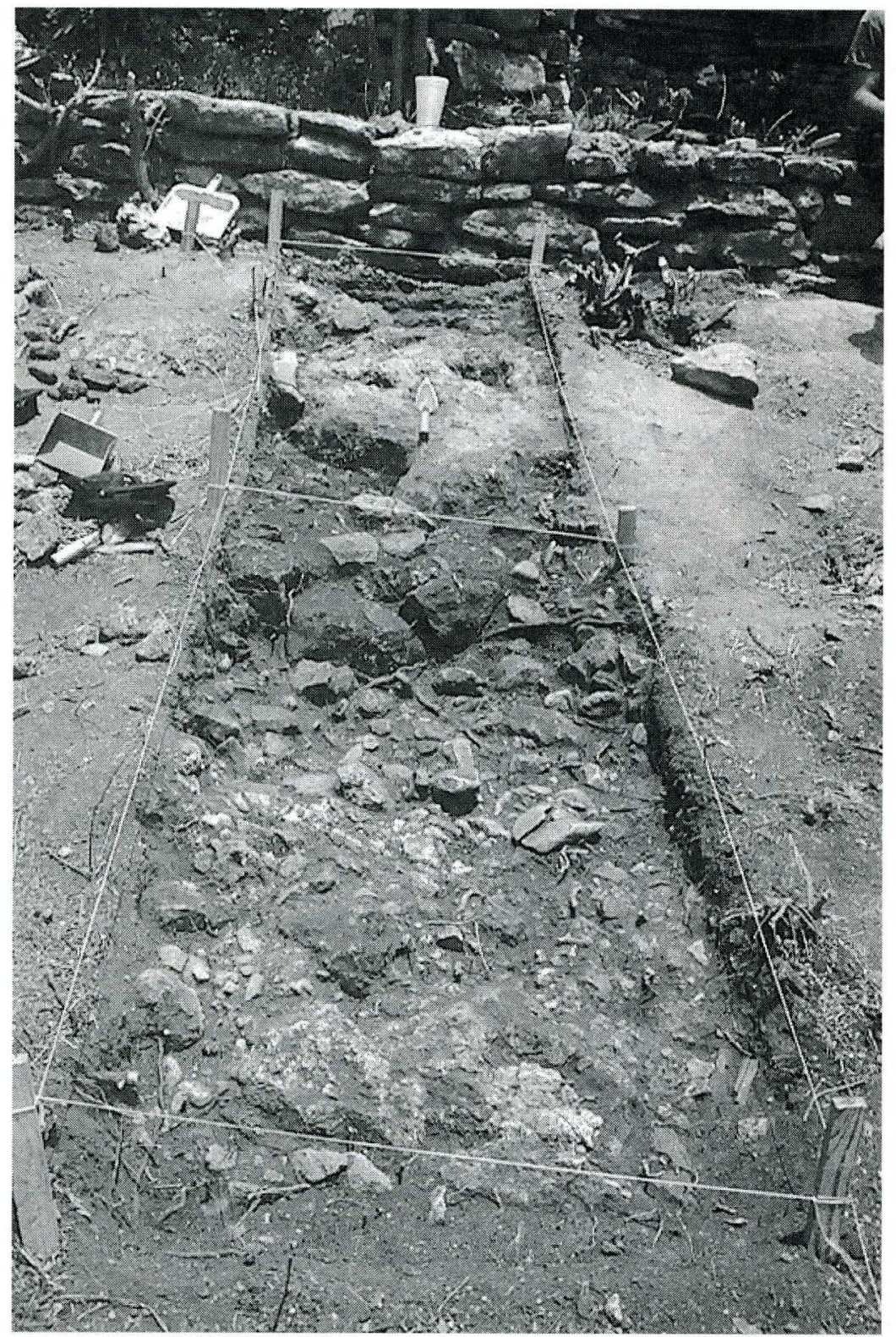

Figure 4-1. Feature 1, firecracked rock and midden debris in Trenches $1 \mathrm{~A}$ and $1 \mathrm{~B}$.

\section{Feature 3}

Feature 3 is a firecracked limestone concentration in a semicircular pattern approximately $7.5 \mathrm{ft}$. at its widest, and $3 \mathrm{ft}$. at its narrowest. Lying on bedrock, it is approximately 12 in. thick at its thickest. It is concentrated primarily within Unit 6 , but also extends into Units 1 and 8 (Figure 4-3). Both historic and presumably prehistoric lithic debris are mixed within the dark brown matrix, indicating that the feature has retained little or no integrity.

\section{Feature 4}

Feature 4 is a limestone bedrock ledge on the eastern edge of the site, downslope from the cabin replica. It was encountered in Units 9, 15 , and 28 , and it has five niches across its face that appear to have been handhewn (Figure 4-4). The northern-most niche is the

with brown sandy loam matrix interstices. Before fully exposed, it appeared to be perhaps a laid walkway or foundation remnant, and was thus assigned a feature number. After fuller exposure in Unit 2, it was determined to be a natural feature from 3 to 5 in. below the surface (Figure 4-2). largest and has a 'chimney' hole in the top, with blackening inside the base and 'chimney,' apparently from burning. A concentration of charcoal was found in the soils just below it, but no evidence of slag or other material that would indicate what was burned. Other cultural material found in front and just below the feature includes 


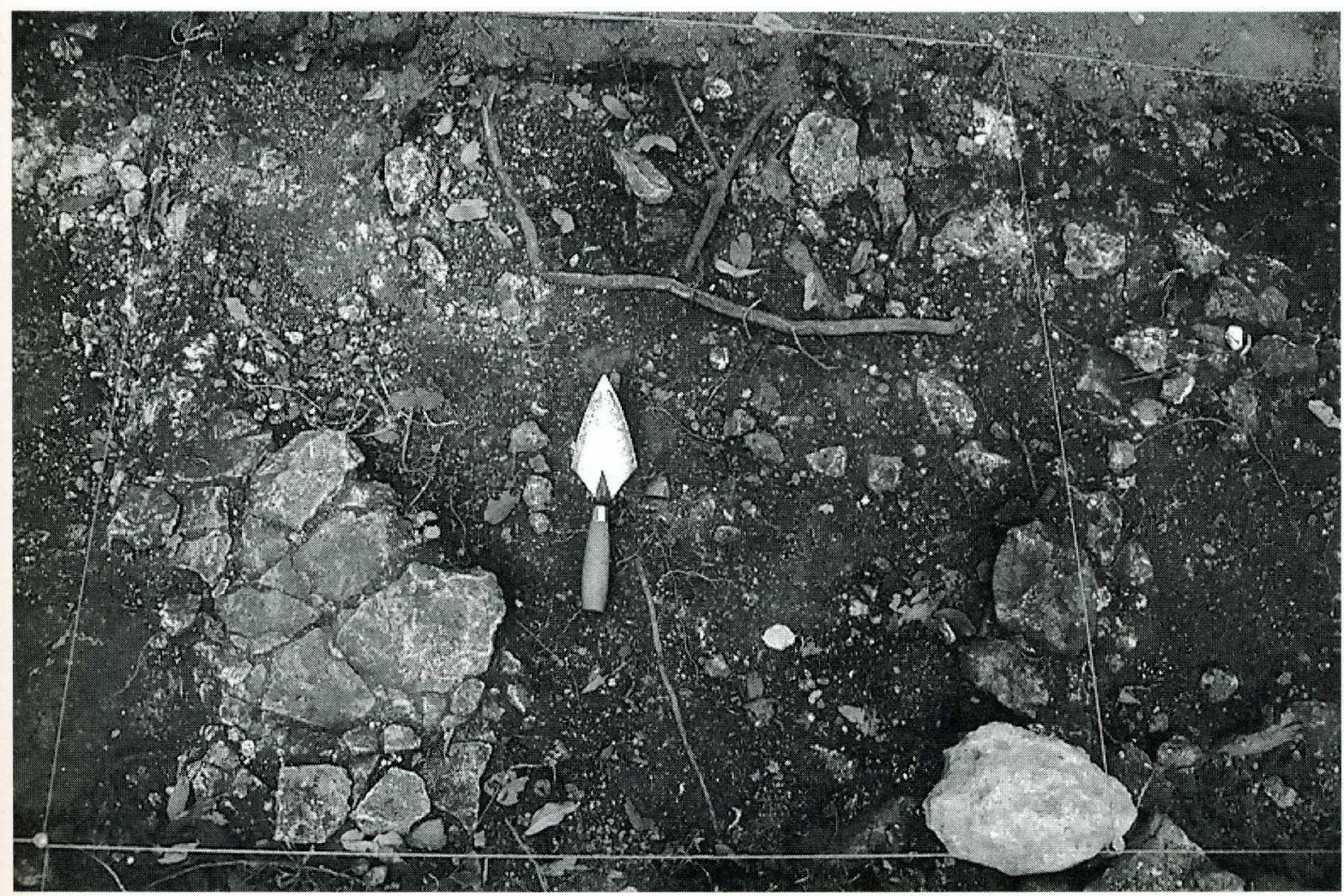

Figure 4-2. Naturally fragmented bedrock designated Feature 2.

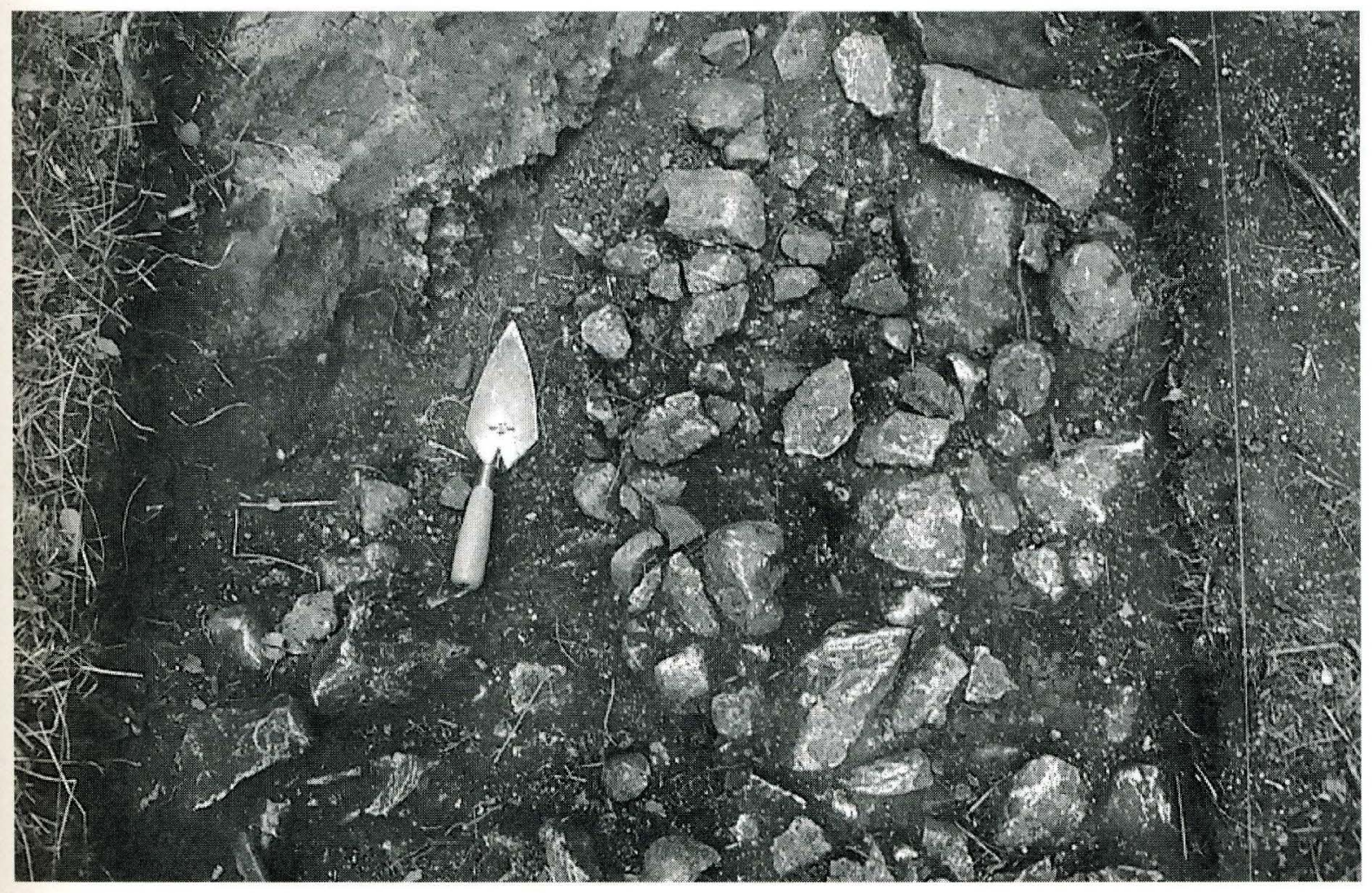

Figure 4-3. Feature 3, firecracked rock concentration in Unit 6. 


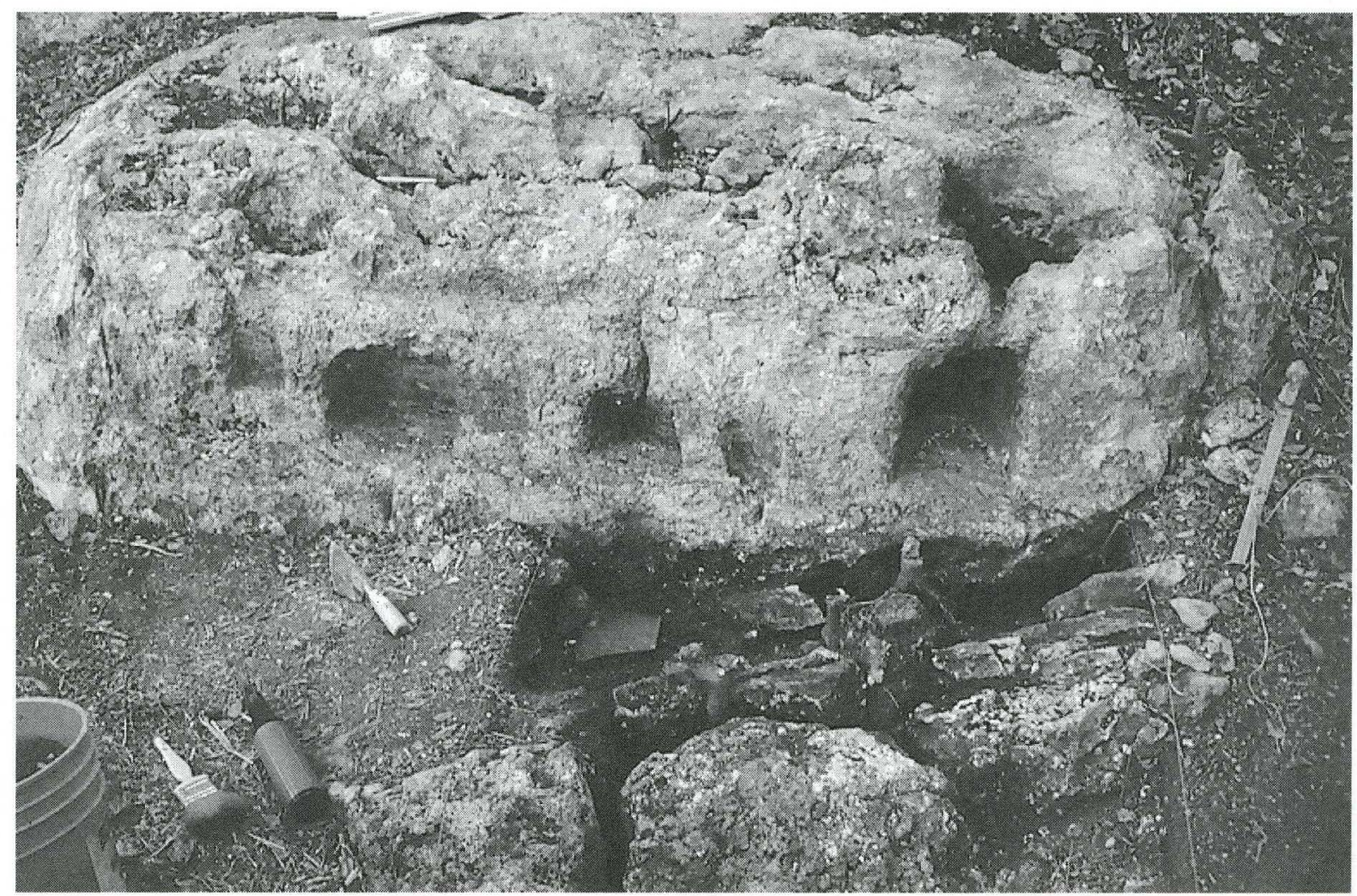

Figure 4-4. Feature 4, hand-hewn bedrock.

lithic debitage, nails, small scraps of tin, glass and historic ceramics.

\section{Feature 5}

Feature 5 is a concentration of firecracked limestone uncovered approximately $1.25 \mathrm{in}$. below the surface in the northern portion of Unit 13, and ephemerally extending into adjacent Units 11 and 14 (Figure 4-5). Lying on undulating bedrock, it is approximately 4 in. thick at its thickest. Burned chert flakes and a core, historic ceramics, nails, and glass were found within the limestone and dark brown soil matrix, thus attesting to its mixed context and indicating that the feature has retained little or no integrity.

\section{Feature 6}

Feature 6 is a concentration of caliche and concrete in Units 18 and 21 that was initially thought to have possibly been associated with a nearby foundation. However, upon further exposure to approximately 24 in. below the surface, it was determined to be a dumping pile, likely for modern construction (Figure 4-6). This was later confirmed by Mr. Isabel Gutierrez, Sr., a maintenance worker at Aquarena Springs in the 1960s. Mr. Gutierrez helped build the Burleson Cabin replica on the site in the 1960s, and confirmed that we had found their mortar and concrete mixing area (Isabel Gutierrez, Sr., personal communication, September 25, 2000; see interview in Appendix J). 


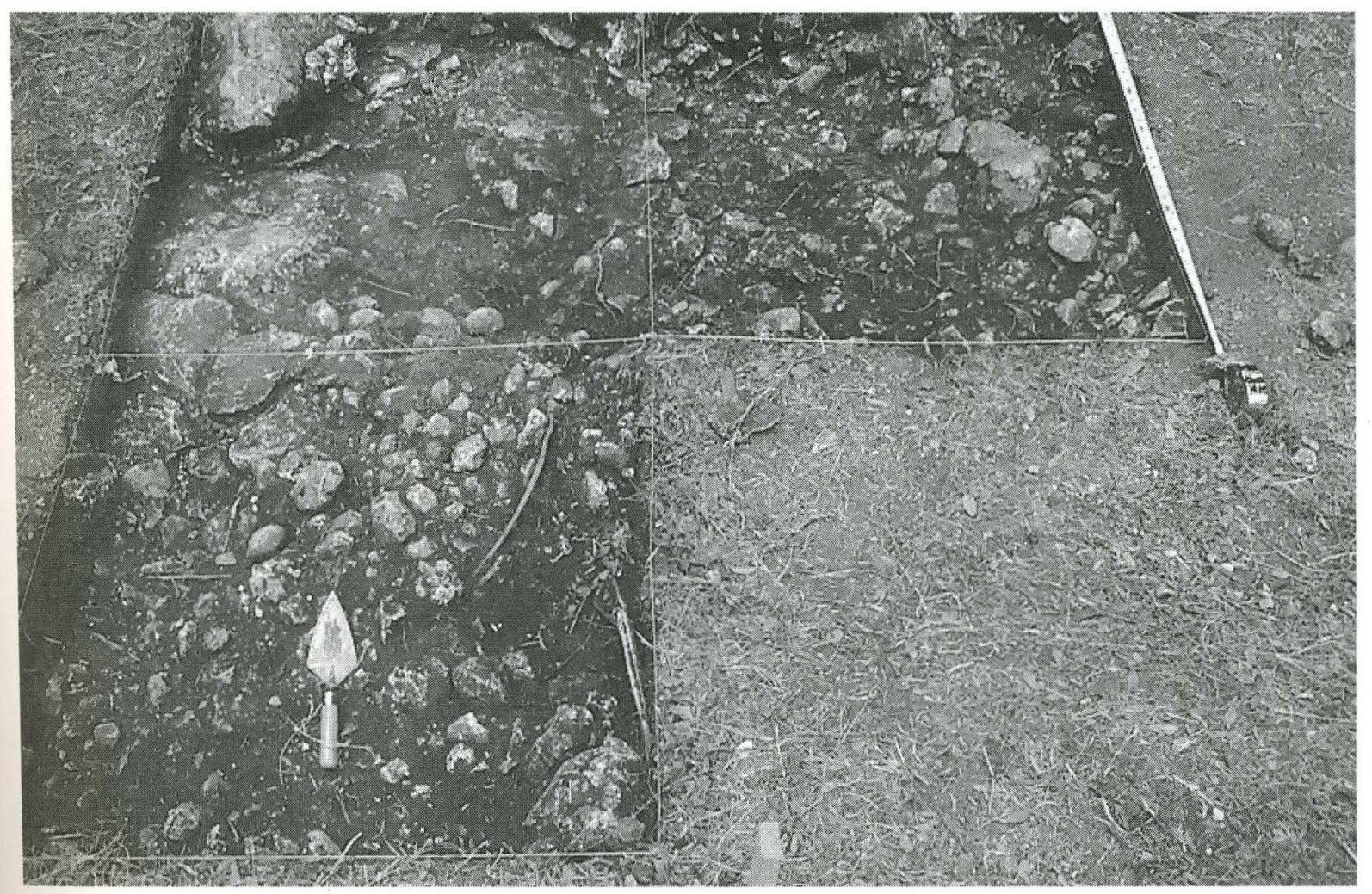

Figure 4-5. Feature 5, firecracked rock concentrated in Units 11, 13, and 14.

\section{Feature 7}

Feature 7 is a natural concentration of limestone slabs found underneath the construction mix (feature) in the southwest corner of Unit 18 (see Figure 4-6). Initially the slabs appeared to be set in place, but further excavation confirmed their natural fracturing and articulation.

\section{Feature 8}

Feature 8 initially appeared to be burned, reddened, and angular chimney stone fragments found 2 to 4 in. below the surface in Units 16 and 25 . However, further excavation revealed that it was a firecracked limestone feature within a dark gray, ashy matrix. In addition to the fractured limestone, historic nails, metal, glass, and mortar, along with presumably prehistoric lithic debitage were found within the matrix, thus attesting to its mixed context and minimal integrity.

\section{Burleson's Dam}

\section{Britt Bousman}

In late May of 2001 SWT exposed the dam in order to repair the structure from damage caused by the October 1998 flood. On May 25, 2001, CAS archaeologists documented the structure. The downstream side of the dam was cleared of vegetation for emergency repair of the dam by architects Freese and Nichols. They installed a driveway over the eastern spillway, and constructed a road down the backside of the dam to the western spillway at Joe's Crab Shack. Trees were removed on the backside of the dam. This area was eventually covered with limestone rock riprap, and a new western spillway constructed. 


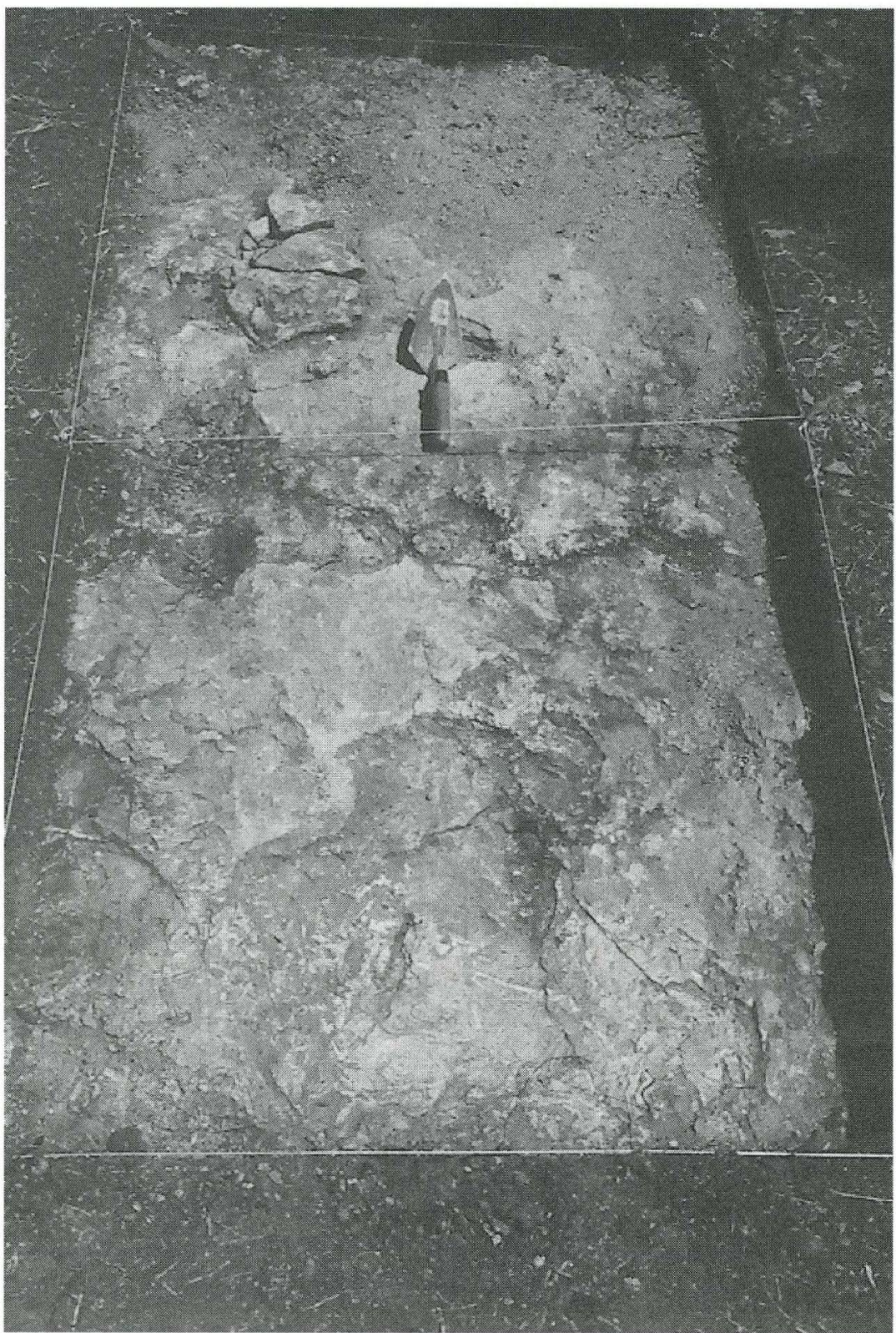

Figure 4-6. Features 6 and 7, concrete mixing area on fractured bedrock.

The dam was exposed, especially near the western spillway, and much of the structure was clearly visible (Figure 4-7). The western spillway consisted of a concrete gate that was built in sections. No evidence was observed that would indicate how much time occurred between constructing the various sections. This spillway might have been built when the Ice House was first constructed in 1883 , or perhaps when it was renovated in 1894 (see Chapter 2). The gate sections rest against a cedar log 'fence.' This 'fence' consists of at least 11 vertical cedar posts placed at 9 to $16 \mathrm{ft}$. intervals (see Figure 4-7). A sample of Post 5 was collected. Behind the vertical posts, toward the body of the dam, are horizontal cedar logs stacked on-side to form a barricade. The horizontal logs are stacked up to five logs high. Clear gaps exist between many horizontal logs. Behind the logs are small to large limestone cobbles. The log 'fence' retains these cobbles. The cobbles range in size from 4 in. to 25 in. A few rare cobbles are larger, but most are in the 12-18 in. range.

At Vertical Post 7 (numbered from west to east) is a concrete spillway that is $4 \mathrm{ft}$. wide, $3 \mathrm{ft}$. $5 \mathrm{in}$. high, and at least $6 \mathrm{ft}$. deep (Figure 4-8). The walls are one ft. thick. It was poured into the existing cedar 'fence,' and has negative impressions of at least five horizontal poles. The height of this spillway is much lower than the existing spillway, so this spillway is probably older than the existing spillways. The lower spillway was filled with 


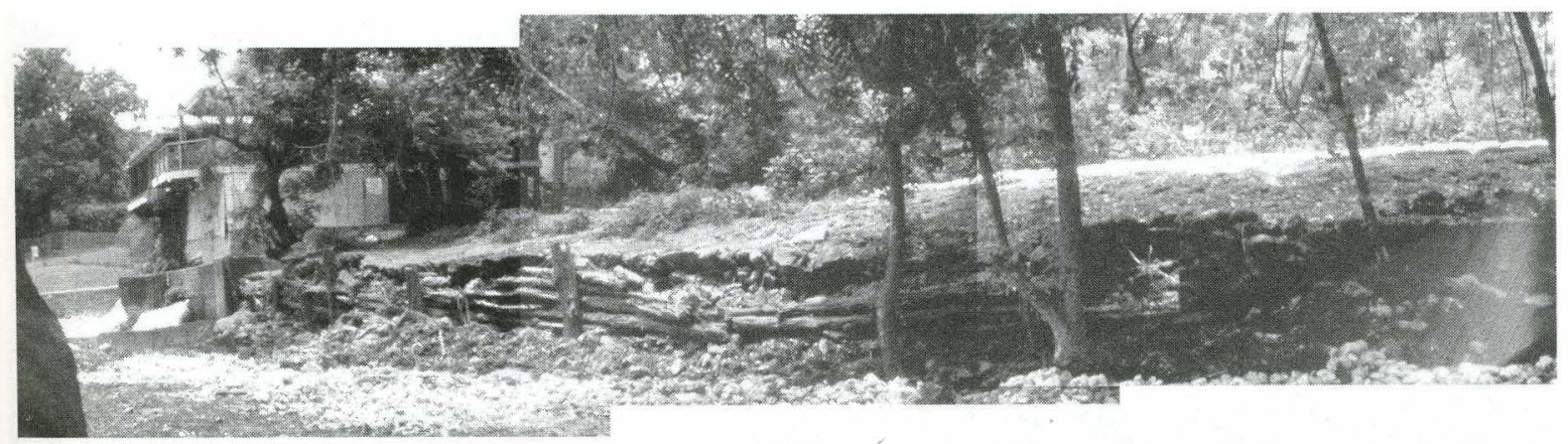

Figure 4-7 (above). Panoramic view of western spillway and dam. Note abandoned spillway immediately to the right of three trees in the center of photograph.

rubble and capped with cement. Its position in the dam suggests that the dam and Spring Lake have increased in elevation through the history of the dam.

The western portion of the dam structure is capped with cement, and there are at least five separate cement caps representing separate events (Figures 4-9 and 4-10). All but the first cap overlap the current spillway. There are two other cement caps below and adjacent to the lower part of the spillway, but these cannot be correlated to the remaining cement caps. All except the first cap postdate the current spillway. The current spillway and the Ice House intake tubes for the turbines are probably coeval with the spillway. The top of the dam has tire tracks in the cement and near the western spillway. A date of February 14, 1991, $(2 / 14 / 91)$ is

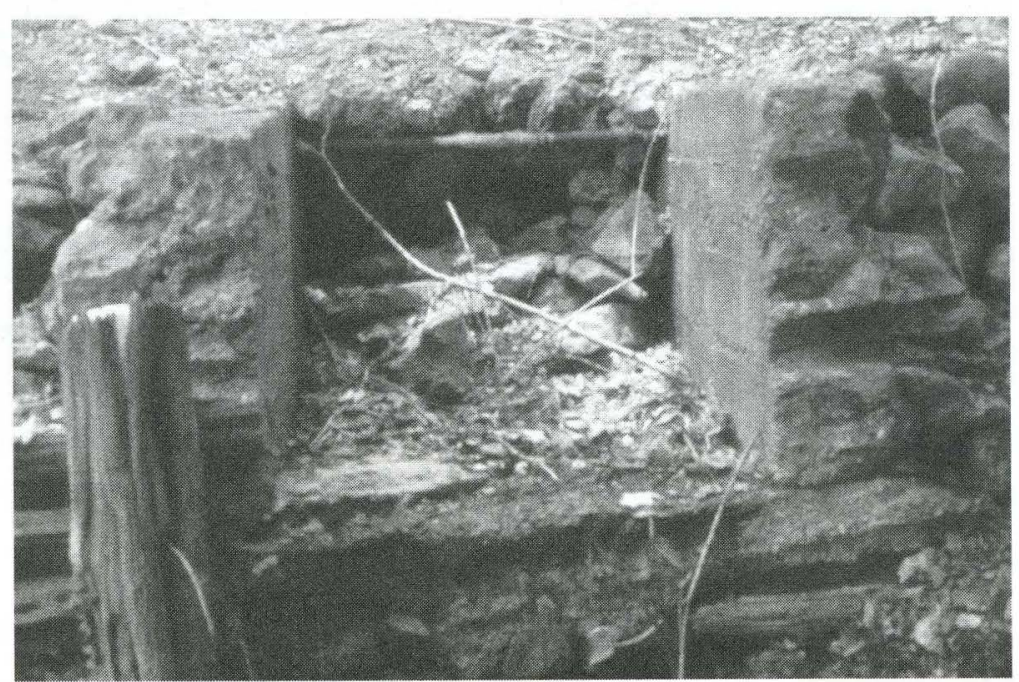

Figure 4-8. Abandoned spillway in center of dam.

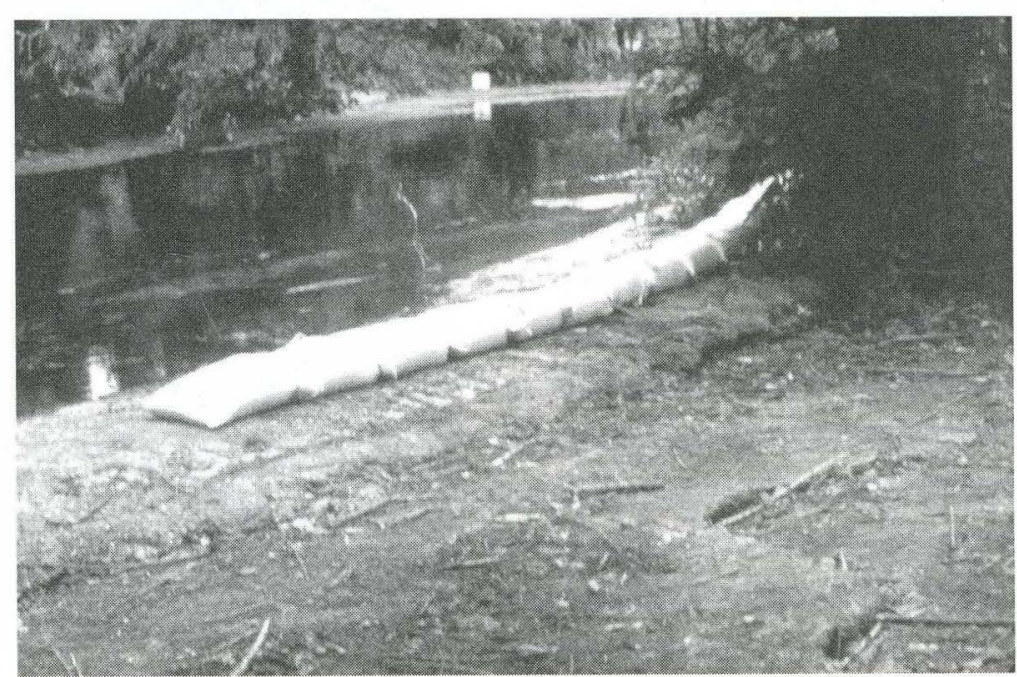

Figure 4-9. Cement caps covering dam. White sandbags placed on most recent cap and three other caps visible to the right of white sandbags. 


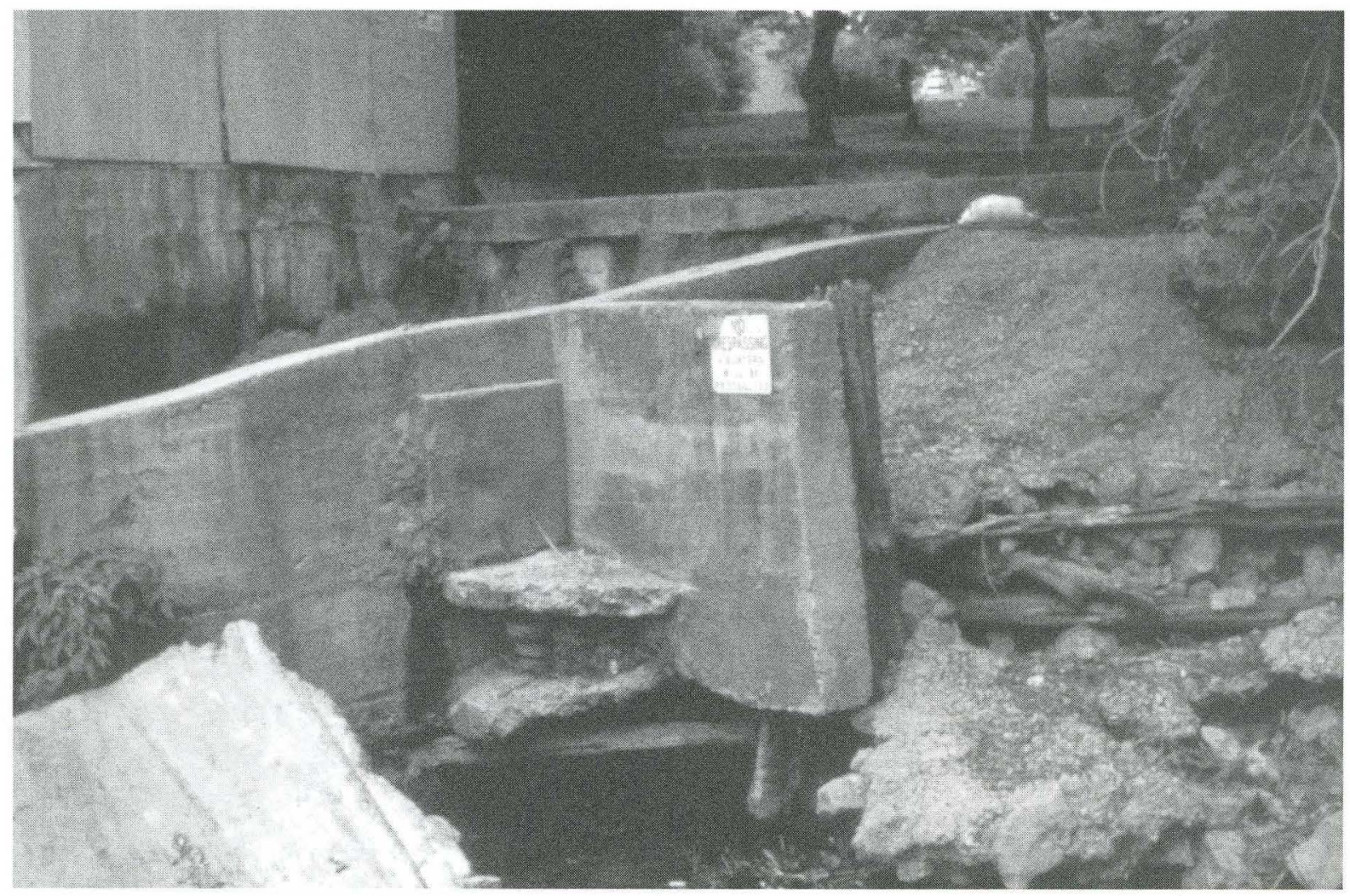

Figure 4-10. Cement cap at western spillway. Cement covers log cribs.

inscribed (Figure 4-11). According to Ron Coley, Director of the Aquarena Center at SWT, the last cap was poured by Aquarena staff on that date. The eastern spillway is much more simple, with a single stage of construction. However, inscribed in the cement of the eastern spillway is the date of Dec. 2, 1909 (Figure 4-12). This is the same year that San Marcos Utilities Company purchased the Mill Tract.

It is unclear if the wooden structure is the original Burleson construction or a

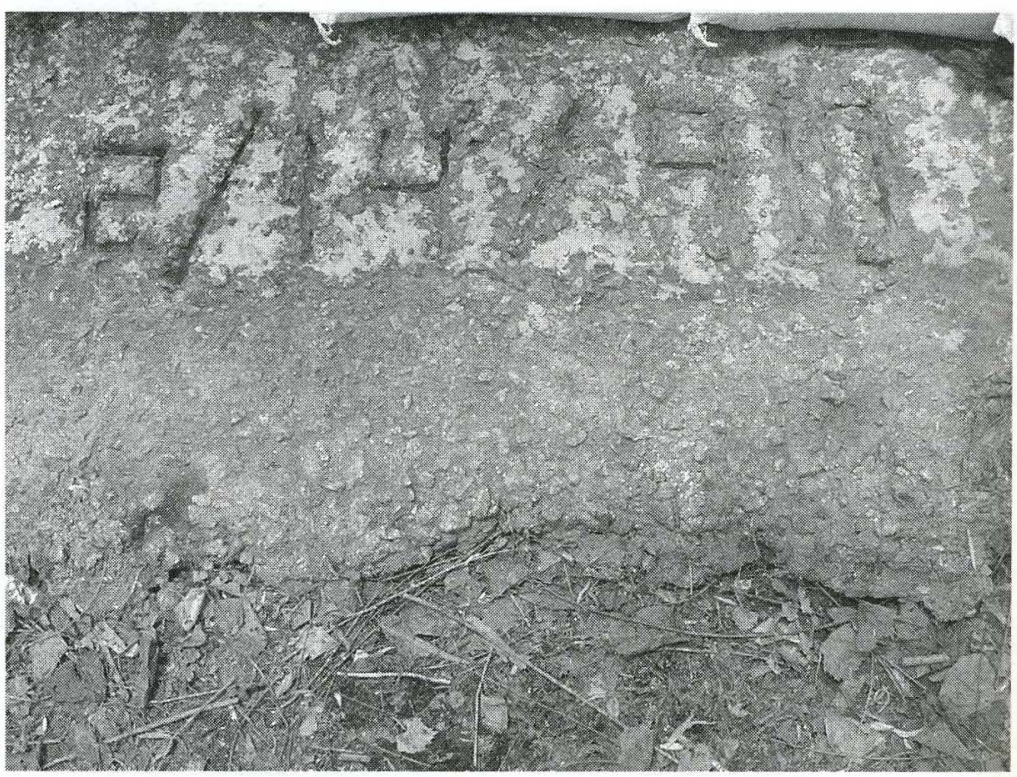

Figure 4-11. Inscribed date of 2/14/91 on most recent cap near western spillway. 


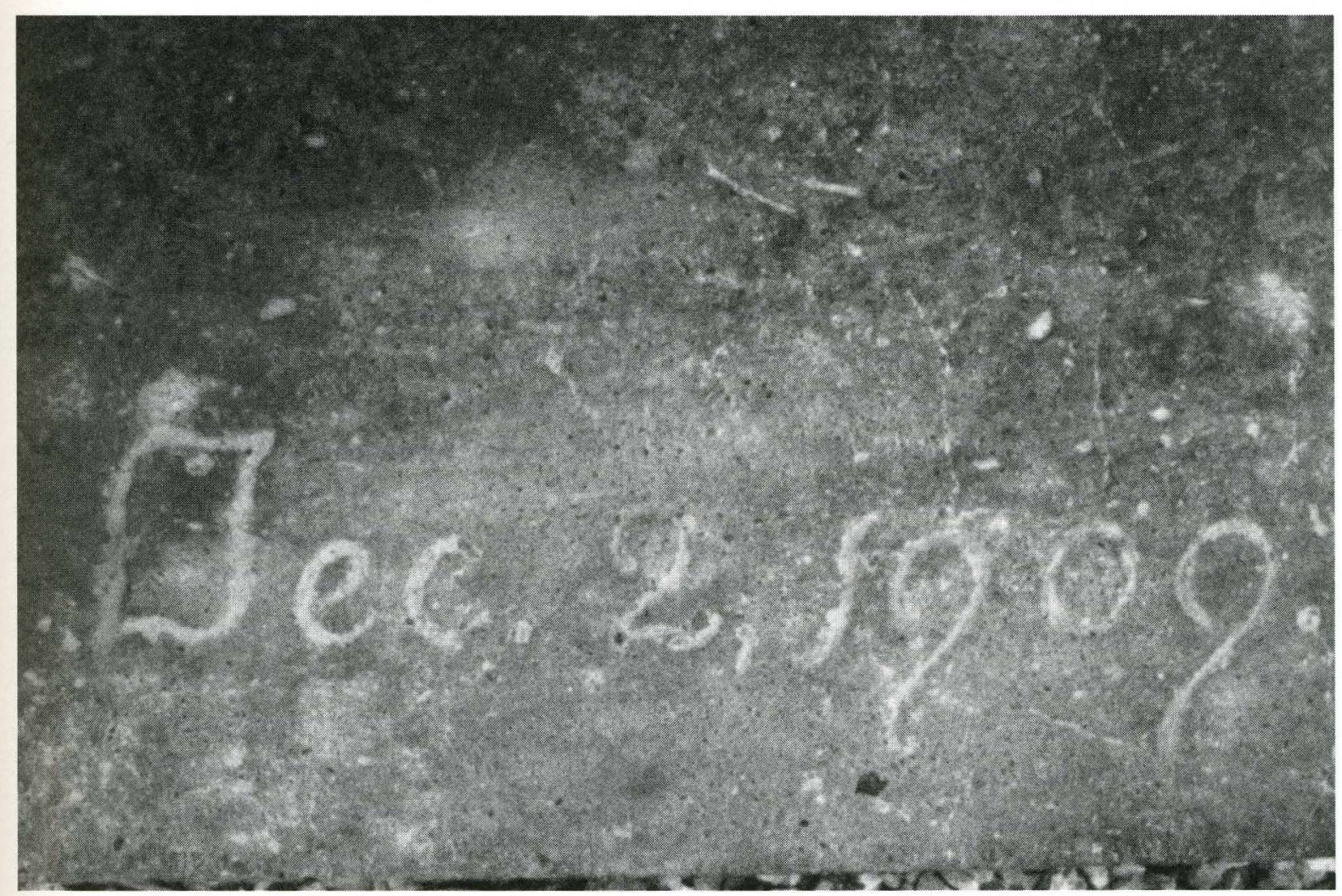

Figure 4-12. Inscribed date of Dec. 2, 1909 on eastern spillway.

later remodeling effort. In any case, the cedar crib construction is probably very similar to the original method of construction. It is remarkable that the dam withstood the October 1998 flood with such little damage. It is likely that the roots of the living vegetation, such as the large bald cypress trees, contributed a great deal to its survival. It appears that the spillways in use as of May 25, 2001, were installed by early in the twentieth century and that most of the cement caps were put in place after their installation. It is obvious that the wooden crib structure predates the current spillways and the abandoned spillway at Vertical Post 7.

\section{Historic Artifact Analysis}

David L. Nickels

\section{Glass}

\section{Bottle and Jar Glass}

\section{Introduction}

Finding a piece of bottle or jar glass with a maker's mark is always helpful in determining its approximate date and place of manufacture, as well as its probable contents. However, there are many other characteristics that can provide clues as to the probable age and contents of bottles, such as mold seams and scars from the manufacturing process, labeling, closure types, and glass color. As technology and customer desires changed through the years, so too did the manufacturing of bottles. It is these discriminators that allow 
archaeologists to approximate their age. Primary reference sources used for the bottle glass analysis were Munsey (1970) and Toulouse (1971). Other specific references are cited within the following text.

\section{Analysis}

Approximately 98 percent of the glass sherds were from bottles and jars. The remaining sherds were from miscellaneous items such as flashbulbs, a lantern, and decorative handblown specimens likely discarded by a modern glass blower who made and sold trinkets there in the recent past. Conspicuously few in number were glass dinnerware sherds; there were perhaps a half dozen in the entire assemblage.

After sorting the glass sherds by color, selected pieces with possibly diagnostic characteristics such as seams, decorations, and makers' marks were pulled from the collection for further examination. Because the individual characteristics of glass often overlap through time, it was decided that this assemblage could best be characterized within three general periods: pre1904, 1904-1930, and post-1930. The year 1904 was chosen because that marked a significant change from handblown bottles to automatic bottle-making machines. The year 1930 was chosen because that marked a significant development in the manufacturing of clear glass that would not assume either amethyst or amber hues. Staying within our focus of identifying artifacts that could possibly be associated with the occupation of the site by General Burleson and his family, those specimens that were determined to fall within the pre-1900 category were examined once again for diagnostic characteristics that could possibly place them temporally on or before 1857 , the year that Elizabeth Burleson sold the Homestead Tract.
Finally-and although admittedly problematic-when no other period-diagnostic characteristics were available, I used glass color, along with personal subjective observations such as thickness, flaws in the glass, and the degree of patination or corrosion in assigning sherds to a particular time period.

A total of 1,414 glass sherds were recovered. However, using the total number for analysis can be misleading, i.e., the total number of sherds undoubtedly misrepresents the total number of individual bottles or glass items from which they were a part. My observations were that there was not a single occurrence of more than one diagnostic neck, base, or other diagnostic feature of the same color and type within the same provenience. Therefore, I assigned a separate lot number to similar sherds from the same provenience, thus reducing the sample size from its original 1,414 specimens to 389 lots (for example, 12 thick dark green body sherds and one neck of the same color and thickness all from Unit 1, Level 1 became simply Lot 1). Of those 389 lots, 138 (35.5 percent) contained glass representing a post-1930 presence at the site; 151 (38.8 percent) could be placed between 1904 and 1930; and it was determined that the remaining 100 lots (25.7 percent) pre-date 1904 . Of the latter category, only five (5 percent) could date to the $1850 \mathrm{~s}$, and thus are possibly associated with the Burlesons' occupation. Selected specimens from the assemblage, labeled by Unique Item (UI) number, are discussed individually in the text and illustrated.

Bottle Glass Possibly Owned by the Burlesons

\section{UI 1 - Unit 1, Level 1 - Flaked Glass}

This specimen is a dark green, thick sherd that 
has been intentionally flaked to use as a small scraper or cutting tool (Figure 4-13a). Its color and thickness suggest that the glass was manufactured before 1880 . Four similar pieces were recovered from the Fanthorp Inn site in Grimes County, Texas, that was occupied beginning in 1832 (Sauer 1998:61). Elsewhere, in Tom Green County, similar specimens have been found infrequently on other late nineteenth century historic sites dating to possibly as early as 1850 (Nickels and Mauldin 2001:72-73; Nickels et al. 2001:175-179).

\section{UI 2 - Unit 1, Level 1 -Patent Medicine Bottle Neck}

This item is an aqua stopper-type closure neck fragment (Figure 4-13b), and is likely part of a patent medicine bottle. It has been finished with a lipping tool and has no observable mold seams, suggesting a date of manufacture most probably between 1850 and 1903 .

\section{UI 3 - Unit 20, Level 1 - Bottle Base}

This is a thick brown bottle base with a slightly concave bottom (Figure 4-13c). It has a postbottom mold seam that indicates that it could have been manufactured any time during the 1800s. However, the absence of a pontil scar suggests it was held with a snap holder, and thus it was more than likely made after 1850 . Due to its thick, yet noted irregularity in thickness, along with heavy patination, I tend to believe its antiquity is nearer 1850. Its characteristics are very similar to Unique Item 5 , a neck found on the surface $18 \mathrm{ft}$. northeast of the cabin.

\section{UI 4 - Unit 20, Level 1 - Bottle Neck}

This specimen is a thick, dark green lip and neck fragment showing an applied lip seam (Figure 4-13d). The point of contact between the lip and neck is distinct, suggesting a ca. 1800 to
1880 period of manufacture. However, the lip has been tooled smooth, suggesting an earliest date of around 1850. In sum, this sherd is from a bottle most probably made between 1850 and 1880 .

\section{UI 5 - Surface, $6 \mathrm{~m}$ Northeast of Cabin - Bottle Neck}

This is a thick, dark brown stopper closuretype neck (Figure 4-13e). Two vertical mold seams on opposite sides of the neck have been partially obliterated by a lip finishing tool. Its brown color suggests a pre-1900 date of manufacture; however, it was made in a blow-back mold and designed to accommodate a stopper-type closure, suggesting a date between 1850 and 1903. Due to its thick, yet noted irregularity in thickness both in the neck and lip portions, along with heavy patination, I tend to believe its antiquity is nearer 1850. Its characteristics are very similar to Unique Item 3 , a base found in Unit 20, Level 1.

\section{Unique Bottle Glass Items Not Associated with the Burleson Occupation}

\section{UI 6 - Unit 13, Level 2 - Bottle Neck}

This specimen is an amethyst-colored neck designed to accommodate a glob top stopper (Figure 4-14a). It has a tooled lip bearing turning scars which partially obliterate a vertical seam mold extending onto the lip. Its lipping tool marks and partially obscured blow-back mold seam suggest a date of manufacture between 1850 and 1903, while its color suggests a date of manufacture between 1880 and 1915. In sum, this specimen was most probably made between 1880 and 1903.

\section{UI 7 - Unit 24, Level 1 - Bottle Body Sherd}

This specimen is a body fragment of a thick, aqua-colored bottle. In its broken condition only one vertical mold seam is visible. Decorations 


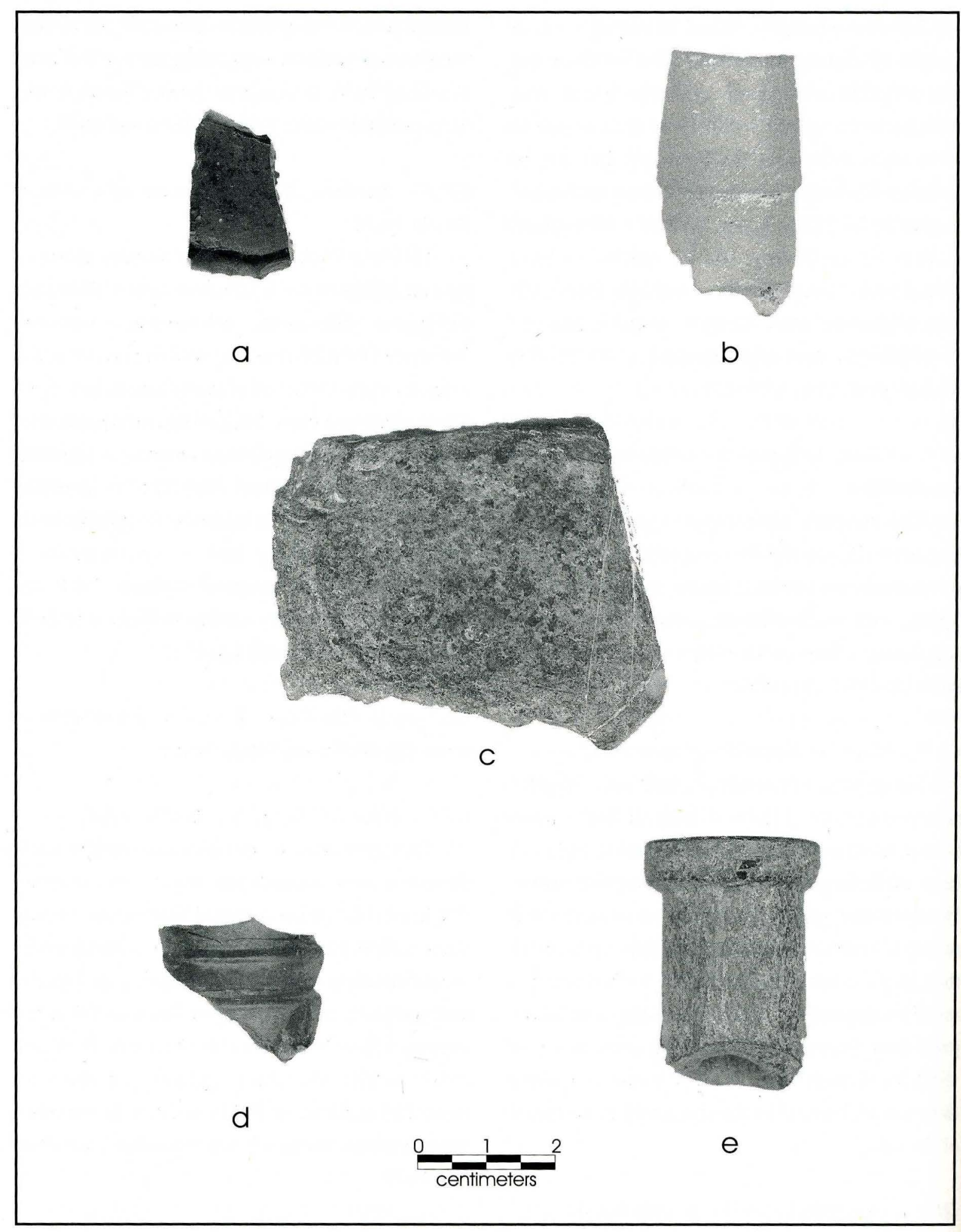

Figure 4-13. Bottle glass possibly owned by the Burlesons: (a) flaked glass - UI 1 - Unit 1, Level 1; (b) patent medicine bottle neck - UI 2 - Unit 1, Level 1; (c) bottle base w/post-bottom mold seam - UI 3 - Unit 20, Level 1; (d) bottle neck fragment w/applied lip seam - UI 4 - Unit 20, Level 1; (e) stopper closure type bottle neck - UI 5 - $18 \mathrm{ft}$. northeast of cabin, Surface. 
include a raised relief design over an etched pattern (Figure 4-14b). Its color suggests a period of manufacture prior to 1900 , and the etching technique implies perhaps as early as the late 1800 s. Further complementing its antiquity is the raised molded design that suggests a post-1869 date. Although of the same colors, this piece is an example of the glass overlay technique, introduced into America around 1850. In sum, this specimen likely dates to the late 1800 s.

\section{UI 8 - Unit 26, Level 1 - Bottle Neck}

This item is a brown bottle neck designed for a stopper-type closure (Figure 4-14c). A blow-back mold seam extending upward onto the lip has been partially obliterated by a finishing tool. The brown color implies a pre-1900 date of manufacture, and the blow-back mold seam implies a date between 1850 and 1903. A final age discriminator is the presence of a barely discernible point of contact between the lip and neck, suggesting a post-1880s technology. In sum, it appears this bottle was made between about 1890 and 1903 .

\section{UI 9 - Unit 13, Level 2 - Bottle Body Sherd}

This item is a very thin, clear glass sherd with an amethyst hue (Figure 4-14d), suggesting an 1880 to 1915 period of manufacture. Its surmised antiquity is complemented by etching and frosting, suggesting a date as early as the late 1800s.

\section{UI 10 - Surface - Bottle Body Sherds}

This UI is comprised of two sherds probably from the same bottle. They are made of clear glass exhibiting an amethyst hue. One has a raised molded design, and the other has part of the word 'patented' on it (Figure 4-14e). Normally, their color alone would suggest a period of manufacture between 1880 and 1915, and the embossed 'patent' would imply a pre-1907 medicine bottle. However, the combination of thick, clear glass with a decorative, ribbed molded design suggest it is not a patent medicine bottle. Thus, based on color alone, it appears this bottle was manufactured between 1880 and 1915 .

\section{UI 11 - Unit 12, Level 1 - Patent Medicine Bottle Body Sherd}

This thin, light green body sherd with heavy patina is from a rectangular bottle, likely a patent medicine bottle. Its raised lettering reads in part “__SVILLE” (Figure 4-14f). Its embossed, versus applied color labeling suggests an 1869 to 1930s date of manufacture; however, it is probably one of the thousands of patent medicine bottles so prevalent before the Pure Food and Drug Act was passed into law in 1907. A similar specimen was recovered during excavations at Fanthorp Inn (41GM79) in Grimes County (Burnett 1981:5152). Fanthorp Inn was occupied from the 1830 s forward (Sauer 1998).

\section{UI 12 - Unit 24, Level 1 - Patent Medicine Bottle Body Sherd}

This sherd is rather thin and light green. The raised letters are " $\mathrm{D}^{\mathrm{R}} \mathrm{KI}$ EW DISCO , (Figure 4-14g). The embossed letters suggest an 1869 to pre-1930 date of manufacture. However, it is probably one of the patent medicine bottles so prevalent before the Pure Food and Drug Act was passed into law in 1907.

\section{UI 13 - Unit 18, Level 2 -Drug Store Bottle}

These two sherds refit so that "__ Drug Sto__ OS, TX__ " is legible in raised molded script (Figure 4-14h). The embossed lettering suggests a post-1869 date, but their purple color suggests an 1880 to 1915 period of manufacture. This bottle was manufactured for a drug store in San Marcos. Archival research located the names of several drug stores in operation in San Marcos around the turn of the twentieth century. The earliest date 
found was 1904. Advertisements placed in the yearbook of the Southwest Texas State Normal School, Pedagogue, indicate M. J. Funk, Druggist and Stationer, operated a drug store at East Side Plaza, San Marcos in 1904. Also operating in 1904 were Raynolds and Daniel, Druggists and Apothecaries, with no location given other than San Marcos, Texas. In the 1905, 1906, and 1907 Pedagogues, C. T. Bass Drugs and Stationery advertised their location at West Side Plaza. In 1909 and 1910, advertisements were placed in the yearbooks for Bass \& Hoting, Druggists, West Side Plaza. By 1909, Heffernan \& Williams were operating a drug store on the north side, with a soda fountain. In 1910, there appeared an advertisement for $\mathrm{H}$. N. Heffernan, the Rexall store. An ad also appeared in 1910 for the San Marcos Pharmacy, successor to Schlottman Drug Company (University Archives, Alkek Library, Texas State University).

\section{UI 14 - Unit 18, Level 2 - Bottle Base}

Unique Item 14 is a thick, clear glass base with an amethyst hue (Figure 4-14i), implying a date of manufacture between 1880 and 1903. It is $3.75 \mathrm{in}$. in diameter and its interior is covered with a coarse sand and concrete mix. On its bottom are mold seams indicating it was machine-blown using a cup-bottom mold, implying it was made after 1903. In sum, this bottle likely dates between 1904 and 1915.

\section{UI 15 - Unit 1, Level 1 - Bottle Base}

This small base fragment is clear with an amethyst hue and a cup-bottom mold seam (Figure $4-14 j$ ). Its color suggests it was likely made between 1880 and 1915 , but the mold seam suggests a post-1903 date. In sum, it most probably was manufactured between 1903 and 1915 .

\section{UI 16 - Unit 28, Level 1 - Bottle Neck}

This is a thick, clear bottle neck with an amethyst hue (Figure 4-14k), suggesting it was made between 1880 and 1915 . It was designed to accept a stopper closure, most commonly used between 1850 and 1903. Although it has a finely tooled lip, a technique common between 1869 and 1903 , it also has two vertical mold seams on opposite sides, running to just above its shoulders. These suggest they are machine-made mold seams, thus indicating a post-1903 date of manufacture. In sum, it appears this specimen was made between 1903 and 1915 .

\section{UI 17 - Unit 22, Level 1 - Bottle Neck}

This specimen is a thin, clear bottle neck with a tooled lip designed for a stopper closure (Figure 4-141). The glass is only slightly thickened, with no hue, and thus appears to be modern; or at the very earliest post- 1930 .

\section{UI 18 - Unit 13, Level 1 -Bottle Body Sherd}

This piece is very thin, clear with a slight amethyst hue, has been etched, and has raised letters (Figure 4-14m). The etching technique suggests it was done perhaps in the late 1800 s at the earliest, and the raised lettering technique suggests a pre-1930 date. In sum, it appears this fancy, decorative container was likely manufactured between around 1890 and 1930 .

UI 19 - Surface, $6 \mathrm{~m}$ Northeast of Cabin Mineral/Soda Bottle Body Sherds

Three sherds of thick, light green glass comprise UI 18. When refitted together, raised lettering reads "A. C. NER BOTTLING WORKS, S__OS, Tex." (Figure 4-14n). The refitted specimen has two mold seams running vertically and opposite each other up the sides. Their color and distinct, crisp lettering suggest a 


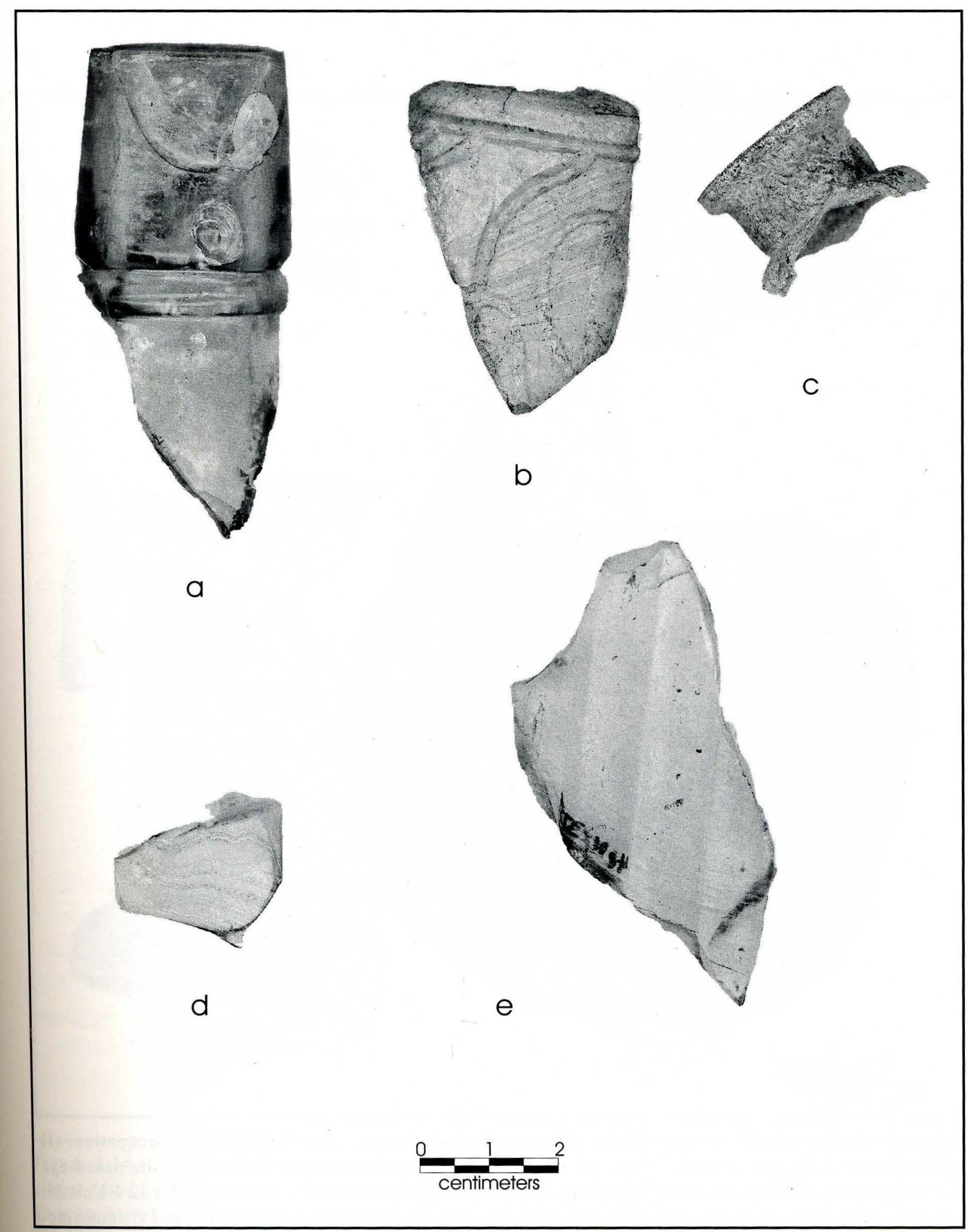

Figure 4-14. Unique bottle glass, but not associated with the Burleson occupation: (a) glob-top stopper type bottle neck - UI 6 - Unit 13, Level 2; (b) raised relief design over etching - UI 7 - Unit 24, Level 1; (c) stopper type closure w/ blow-back mold seam, tool-finished lip - UI 8 - Unit 2, Level 1; (d) etched and frosted - UI 9 - Unit 13, Level 2; (e) ribbed molded, and embossed lettering - UI 10 surface. 


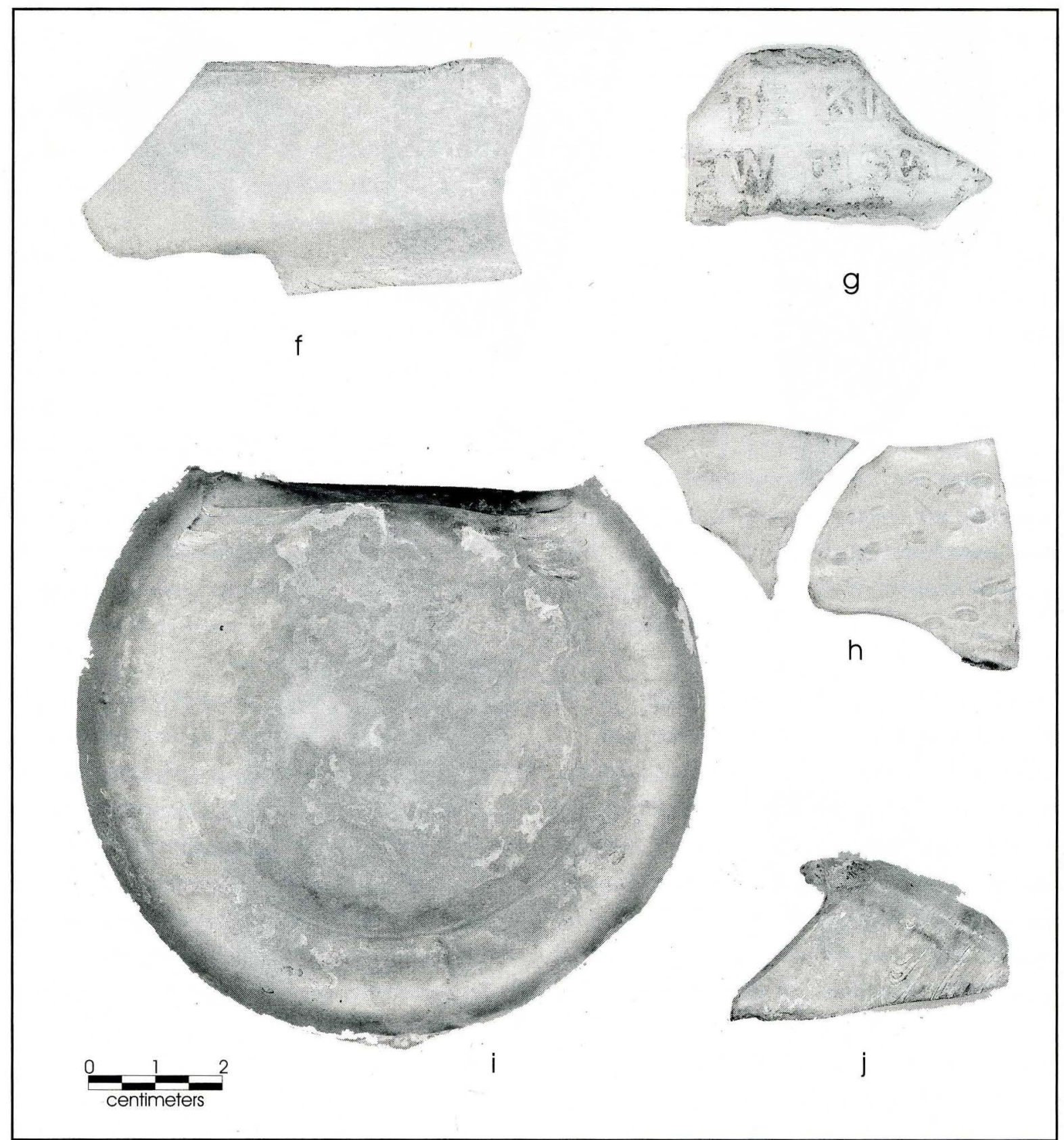

Figure 4-14 (continued). Unique bottle glass, but not associated with the Burleson occupation: (f) patent medicine bottle - UI 11 - Unit 12, Level 1 (embossed lettering is invisible to the naked eye and was graphically enhanced for illustrative purposes); (g) patent medicine bottle - UI 12 - Unit 24, Level 1; (h) bottle from drug store in San Marcos - UI 13 - Unit 18, Level 2; (i) and (j) machineblown with a cup-bottom mold - UIs 14 and 15 - Unit 18, Level 12, and Unit 1, Level 1, respectively. 


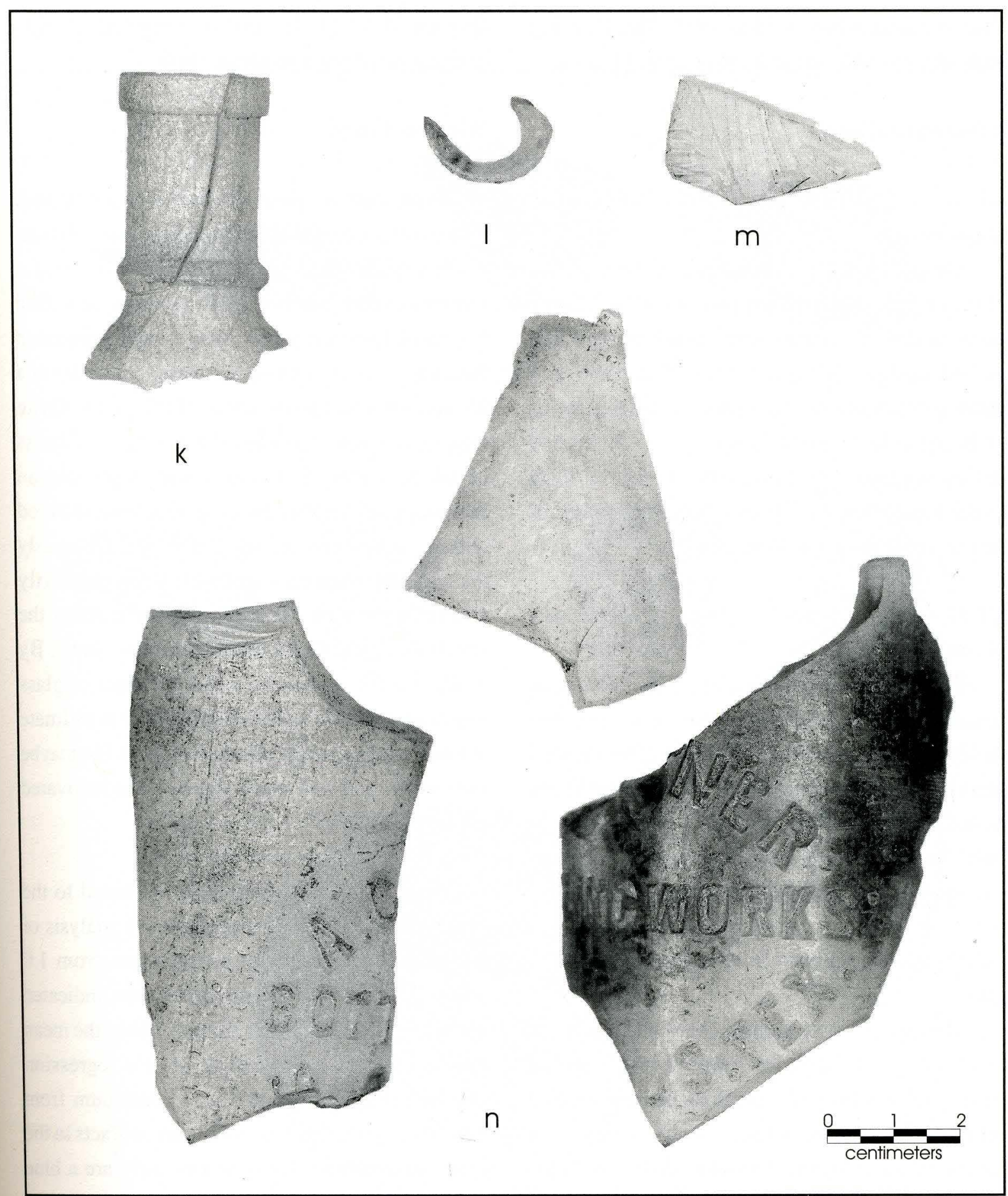

Figure 4-14 (continued). Unique bottle glass, but not associated with the Burleson occupation: (k) stopper closure type neck - UI 16 - Unit 28, Level 1; (1) stopper closure neck w/tooled lip - UI 17 Unit 22, Level 1; (m) etched, w/raised lettering - UI 18 - Unit 13, Level 1; (n) A.C. ner Bottling Works, San Marcos, TX - UI $19-18 \mathrm{ft}$. northeast of cabin, surface. 
date of manufacture around 1950. The lettering indicates possible use and sale in San Marcos.

Tableware Glass

UI 20 - Unit 30, Level 1 - Decorative Dinnerware

Unique Item 20 is comprised of three pieces of thin purple dinnerware glass, possibly a fancy bowl or dish decorated with raised molded and etched designs (Figure 4-15a). The color and etching technique complement each other in terms of being able to age this specimen. Its etched design suggests it could have been made as early as the late $1800 \mathrm{~s}$, and its color suggests a date of manufacture between 1880 and 1915 .

\section{UI 21 - Unit 2, Level 1 -Pressed, or Pattern Glass}

Two sherds of pattern glass with decorative patterns similar to those common on pressed tableware comprise UI 21 (Figure 4-15b). Pressed glass was commonly produced in the United States by the 1860s (Husfloen 1994:175). However, these two sherds are clear, with no noticeable hue, suggesting they were manufactured after 1930.

\section{UI 22 - Unit 11, Level 2 - Pressed, or Pattern Glass}

This specimen is a thin, clear sherd with an amethyst hue. Its delicacy suggests it was part of a fancy table setting. Decorations include a raised relief design (Figure 4-15c). Its color suggests a period of manufacture between 1880 and 1915 , and as stated in the previous paragraph, the pressed glass had been commonly produced 20 years before that period.

\section{UI 23 - Unit 21, Level 2 - Goblet Base}

Unique Item 23 is a purple-colored goblet base
(Figure 4-15d). Its color suggests it was manufactured prior to about 1900 .

\section{Window Glass}

Even window glass can potentially be dated. As a general rule, the older window glass is thicker. Archaeologist Randall Moir (1988) devised a formula to date window glass, accurate to within a span of fourteen years. Moir's data regression formula yields a regression coefficient of .93 at a 95 percent confidence level of \pm 7 years. Quite simply, the equation uses the average thickness of window glass found at a site to provide an approximate date that the glass was manufactured within \pm 7 years of the estimated age. Obviously the date of manufacture does not necessarily represent the date the glass was brought to the site, but it does offer a reasonable time frame. By looking at the variations in the thickness of glass found on a site, we are sometimes able to estimate not only when a house or barn was built, but maybe even when, and how many times, it was renovated (Moir 1988:264).

A total of 102 sherds were measured to the nearest millimeter, and a preliminary analysis of the range in thickness in a continuum from 1.0 $\mathrm{mm}$ to $2.8 \mathrm{~mm}$, with no gaps in between, indicated a potential problem in the sample. When the mean thicknesses were applied to Moir's regression formula, the dates ranged in a continuum from 1790 through 1955 . The only other artifacts in the entire assemblage that date this early are a blue edgeware ceramic sherd (UI 24), dating from 1795 to1825, and five blue spatterware sherds (UI 25) dating from 1800 to 1850 . While glass dating to the last half of the nineteenth century, and through the twentieth century is feasible, the earliest known occupation at the site was by General Burleson in 1848. Therefore, the thinner glass 


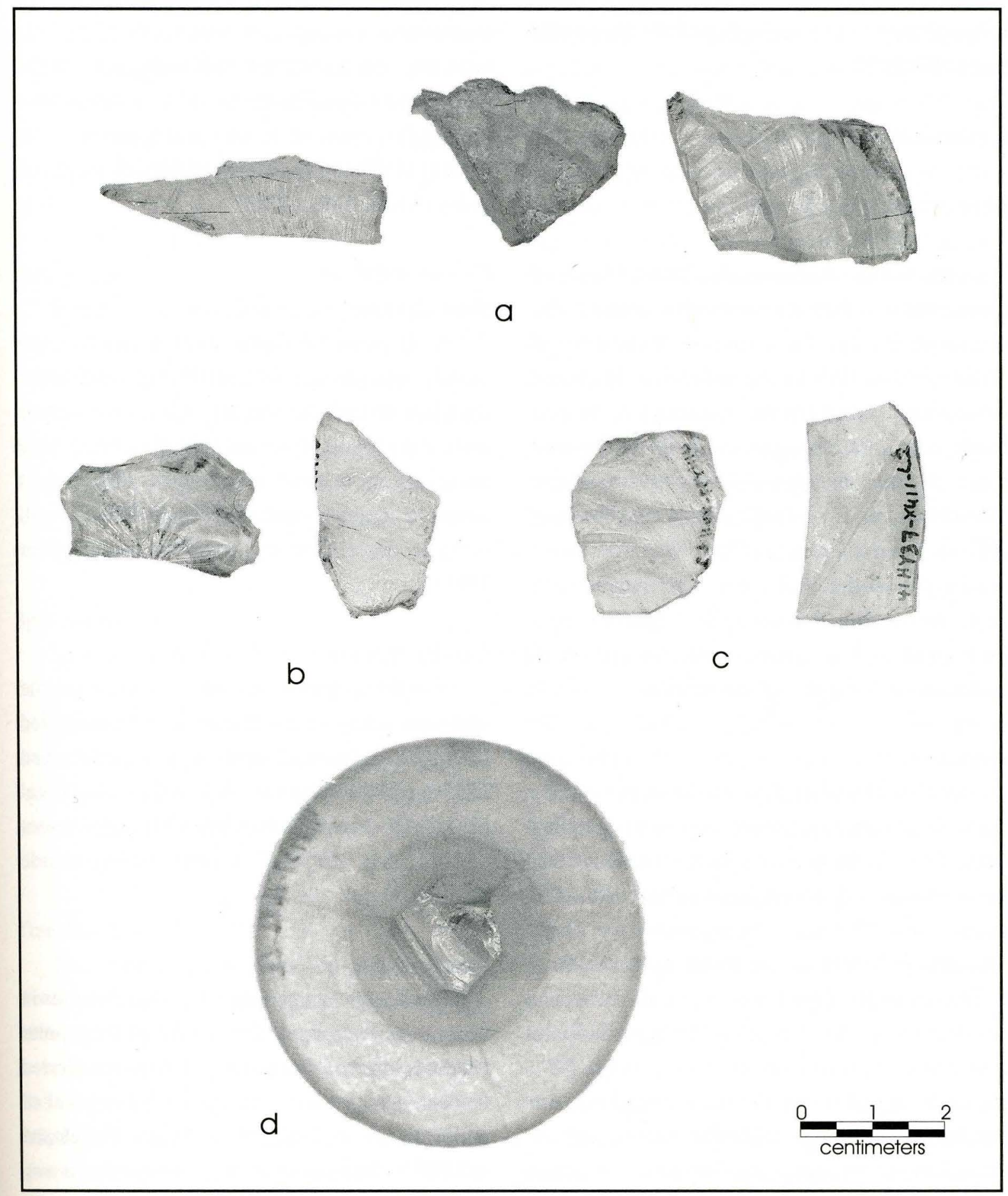

Figure 4-15. Tableware glass: (a) raised molded and etched - UI 20 - Unit 30, Level 1; (b) pressed glass - UI 21 - Unit 2, Level 1; (c) pressed glass - UI 22 - Unit 11, Level 2; (d) goblet base - UI 23 - Unit 26, Level 2. 
which yielded dates prior to 1848 are problematic. One explanation is that they are small sherds, and although they were examined carefully, they could be flat bottle glass.

\section{Ceramics}

\section{Dinnerware}

This section discusses the various types of dinnerware ceramics recovered around the Burleson Cabin. They include undecorated whiteware, as well as the following decorated whitewares: transferware, spatterware, banded ware, edgeware, spongeware, and handpainted ware. A few stonewares are present in the assemblage, as is a small quantity of porcelain. Also included is a variety of local wares produced on the site in the 1970s that I generically call earthenware. Finally, although it may not be a dinnerware item, a ceramic bottle neck fragment is described at the end of this section.

\section{Earthenware}

Generically, the term earthenware can be applied to a variety of baked clay wares, including those listed in the previous paragraph. However, in this project, I choose to apply the term to a small portion $(n=39)$ of the ceramic assemblage which was obviously made in the 1970s. In the 1970s, a local ceramicist plied his trade on the site near the Burleson Cabin replica (Francis Stovall, personal communication 2000) (see Figure 3-3). As such, mixed within the total assemblage are 39 sherds of generally low-fired quality, and are glazed, unglazed, and painted vessels. Two of the pieces are inscribed 'John 75' (Appendix C).

\section{Undecorated Whiteware}

Whiteware is a highly fired refined clay with a vitreous surface. Whiteware was commonly imported to America from Britain during the 1800 s, but the demand for undecorated ware increased significantly in America by 1860 . This type became a common tableware setting for middle class families in this area of Texas after the 1860 s, replacing pewter and wooden wares (Fox et al. 1989:45), and are still being produced today (Miller 1991, 1993).

\section{Decorated Wares}

Band and Line

Aptly named because of from one to three blue, brown, green, and/or red lines painted under the glaze around the rim, Band and Line vessels were most popular from about 1875 to 1900 . They were common hotel wares and consisted of ironstone plates, saucers and bowls. They are still being produced in limited quantities today (Miller 1991:7).

\section{Cut Spongeware}

Basically, sponges are cut into a pattern, the sponge is daubed in paint, and the pattern applied to the vessel. This technique was popular between 1845 and 1900, and most frequently in small floral patterns (Bagdade and Bagdade 1991:325; Greaser and Greaser 1967). Common colors include yellow and red.

\section{Decalcomania}

Basically, in using the decalcomania decoration technique, designs inked in popular bright colors and floral designs were transferred from thin paper onto the vessel. It is typical of tableware used for the past 150 years. Developed in 1850 by Minton's potters in England as a way to decorate cheap tableware (Ramsay 1976:108), this type of tableware became quite popular during the mid-nineteenth century, and is still used today (Durrenberger 1965:66). 
Edgeware

Edgeware pieces are identified by their cockled or non-cockled edges that have been incised and/or painted. Edgeware was made as early as about 1770 and continued into the 1890s. However, the green colored edges were generally superceded by blues around 1840 (Miller 1989; 1991:6).

\section{Handpainted}

Polychrome painted table settings with "red, black, and some lighter shades of blue and green" (Miller 1991:8) became popular during the 1830s. By the 1840 s, common designs included sprigs, often combined with the cut sponge technique. These motifs were superceded in the 1870 s by large floral designs (Miller 1991:8), popular through about 1900.

\section{Spatterware}

Spatterware, popular from $1800-1850$, is aptly named for its spatter-painted appearance, as though it has been crudely sprayed, or patted onto the vessel. Colors include red, blue, green, black, brown, pink, green, and yellow; blue is by far the most common (Bagdade and Bagdade 1991:317; Greaser and Greaser 1967).

\section{Transferware}

The technique of transfer-printing was developed in England in the late 1740s (Atterbury 1979:144). By the late eighteenth century, this technique was designed to be a low cost way of elaborating the design on a vessel compared to painting the decoration by hand (Miller 1980:4). However, employing skilled engravers to etch the decorations on copper plating did not provide a cheaper product compared to other types of decorated ware during the late 1700s (Samford 1997:3).
With the development of more reasonably priced white earthenware with an alkaline glaze in England about 1810, transferware became more popular (Miller 1980:4; Ramsay 1976:152). And, with the end of the War of 1812, transfer-printed ware became popular in American markets through the mid-nineteenth century (Miller 1980:4). A large number of these wares were exported to the coastal ports of Texas, and redistributed to the major cities to meet consumer demand (Labadie 1986:111). By the mid 1850s the demand for transfer-printed wares in the United States was declining (Miller 1980:4). In Texas this trend is reflected by the increasing popularity of undecorated white graniteware between 1850 and 1870 (Blake and Freeman 1998:18; Miller 1980:4).

The majority of transferwares coming into Texas were imported from England but the naval blockades off Texas' coast during the Civil War disrupted the Texas market. Even the post-Civil War years (Reconstruction), would have been difficult for the market of transfer-printed wares since hard cash was scarce. However, there was a short popularity in American markets for the flowblue transfer-printed pattern from 1880 to about 1890 (Blake and Freeman 1998:18). At the end of the nineteenth century, the increased use of decals as a decorating technique for ceramics probably caused the decline of transfer-printed wares (Majewski and O'Brien 1987:147; Samford 1997:25).

Transfer-printed wares with a central undecorated area usually surrounded by a floral pattern continued to flourish (Samford 1997:25) and the 1902 Sears, Roebuck Catalogue offered them as a cheap, inexpensive table setting. Although they are still being produced today, their peak popularity periods as further defined by 
Gilmore (1986),Hume (1970), and Blake and Freeman (1998) are black (1750-1780), blue (1780-1800), red, brown and lavender (1830$1840)$, flow blue (1840-1850; 1880-1890), and polychrome (post-1850).

\section{Ironstone}

Ironstone is a highly fired earthenware that can be decorated or undecorated. It was, and still is, a common dinnerware.

\section{Porcelain}

A small amount of Chinese porcelain, imported to Mexico on the Manila galleons, is present on nearly every Spanish colonial site in Texas. It can be differentiated from European and American porcelain by a very slightly blue-gray tint on the body, and when decorations are present, the grayish blue designs lie beneath the glaze, or delicately painted orange floral designs lie over the glaze. Porcelain is rarely present on eighteenth and early nineteenth century sites because the fragile ware had to be transported from Europe (Ivey and Fox 1981:35), but became more common after 1832, when it was commonly manufactured in the United States (Barber 1976:126-127).

\section{Stoneware}

Stoneware is a utilitarian ware and was commonly used in Texas kitchens and dairies from 1860 through 1950 (Greer 1981:13-26). Popular stoneware found in the area includes Albany Slip/ Bristol glaze and Bristol Glaze. The combination of Albany Slip (brown slip) and Bristol glaze (white) appeared in the first quarter of the twentieth century and was continuously used until about 1920. Vessels with an Albany slip on the inside and Bristol glaze on the outside were generally made before 1900 . Bristol glaze on both the interior and exterior then became the dominant type of stoneware used after 1920, and through about 1950 (Greer 1981:212).

\section{Analysis of Tableware Ceramics}

A total of 406 tableware ceramic sherds were recovered from both the surface and excavation units (Appendix C). Of those, 86 were determined to be modern soft earthenware or stoneware, likely discarded by the ceramicist operating a kiln in the immediate vicinity in the 1970 s. Of the remaining 320 sherds, 230 (69.3 percent) are undecorated whiteware, 38 (11.4 percent) are transferwares, 14 (8.1 percent) are stoneware, 9 (2.7 percent) are porcelain, 8 (2.4 percent) are handpainted, 8 (2.4 percent) are spatterware, $2(<1$ percent) are band and line, $2(<1$ percent) are banded slip, $2(<1$ percent) are cut sponge, $2(<1$ percent) are ironstone, 1 ( $<1$ percent) is decal printed, $1(<1$ percent) is edgeware, 1 ( $<1$ percent) is yellowware, 1 ( $<1$ percent) is a salt-glazed and painted whiteware, and 1 ( $<1$ percent) is indeterminate.

An examination of Table 4-2 presenting the percentages and probable dates represented in the household ceramic assemblage indicates there are 11 different types of household ceramics that could possibly be associated with the Burleson family's occupation of the site. The oldest (1795-1825) is a blue edgeware sherd (Figure 4-16a) that dates between 1795 and 1825, and could be a family heirloom. Next are pieces of spatterware (one specimen is shown in Figure 4-16b) dating between 1800 and 1850. Edward and Elizabeth Burleson's association with many of the remaining pieces becomes more problematic, as the artifacts' initial dates of manufacture are nearer the end of the Burleson era, and their popularity in use extends well beyond the Burleson occupation. Most problematic is the undecorated whiteware 
Table 4-2. Probable ages of the tableware ceramic assemblage at $41 \mathrm{HY} 37$.

\begin{tabular}{|c|c|c|c|c|c|c|}
\hline $\begin{array}{c}\text { Type of } \\
\text { Dinnerware }\end{array}$ & $\begin{array}{c}\text { No. } \\
\text { Sherds }\end{array}$ & Percentage & $\begin{array}{c}\text { Probable } \\
\text { Dates }\end{array}$ & $\begin{array}{c}\text { Possible } \\
\text { Burleson } \\
\text { Era }\end{array}$ & $\begin{array}{c}\text { Probable } \\
\text { Burleson } \\
\text { Era }\end{array}$ & Illustrated \\
\hline Undecorated Whiteware & 229 & 69.0 & 1850-present & $\mathrm{X}$ & & $\mathrm{X}$ \\
\hline w/ maker's mark & 1 & $<1$ & $1890-1925$ & & & $\mathrm{X}$ \\
\hline \multicolumn{7}{|l|}{ Transfer Ware } \\
\hline blue & 35 & 10.5 & $1880-1900$ & & & \\
\hline green & 1 & $<1$ & Pre-1900 & & & \\
\hline sepia & 1 & $<1$ & Pre-1900 & 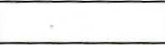 & & \\
\hline pink & 1 & $<1$ & $1853-1900$ & $\mathrm{X}$ & & $\mathrm{X}$ \\
\hline \multicolumn{7}{|l|}{ Stoneware } \\
\hline Albany/Albany & 3 & $<1$ & $1875-1900$ & & & \\
\hline alkaline/alkaline & 2 & $<1$ & $1850-1900$ & $\mathrm{X}$ & & \\
\hline salt & 2 & $<1$ & $1850-1900$ & $\mathrm{X}$ & & \\
\hline salt/Albany & 6 & 1.8 & $1850-1900$ & $\mathrm{X}$ & & \\
\hline Bristol & 1 & $<1$ & Post-1900 & & & \\
\hline \multicolumn{7}{|l|}{ Handpainted Ware } \\
\hline glazed and painted & 1 & $<1$ & Indeterminate & & & \\
\hline sprigs & 5 & 1.5 & $1840-1870$ & $X$ & & $\mathrm{X}$ \\
\hline large floral & 3 & 0.1 & $1870-1900$ & . & & \\
\hline Spatterware & 8 & 2.4 & $1800-1850$ & & $\mathrm{X}$ & $\mathrm{X}$ \\
\hline Decalcomania Ware & 1 & $<1$ & $1890-1930$ & & & $\mathrm{X}$ \\
\hline Porcelain & 9 & 2.7 & 1840-present & $\mathrm{X}$ & & \\
\hline Band and Line Ware & 2 & $<1$ & 1875-present & & & $\mathrm{X}$ \\
\hline Banded Slip & 2 & $<1$ & Post-1840 & $\mathrm{X}$ & & \\
\hline Cut Spongeware & 2 & $<1$ & $1845-1900$ & $\mathrm{X}$ & & $\mathrm{X}$ \\
\hline Edgeware & 1 & $<1$ & $1795-1825$ & & $\mathrm{X}$ & $\mathrm{X}$ \\
\hline \multicolumn{7}{|l|}{ Ironstone } \\
\hline w/ maker's mark & 1 & $<1$ & $1879-1884$ & & & $\mathrm{X}$ \\
\hline w/ maker's mark & 1 & $<1$ & Post-1937 & & & $\mathrm{X}$ \\
\hline Yellowware & 1 & $<1$ & $1850-1900$ & $\mathrm{X}$ & & $\mathrm{X}$ \\
\hline Indeterminate Type & 1 & $<1$ & Indeterminate & & & \\
\hline Total & 320 & & & & & \\
\hline
\end{tabular}

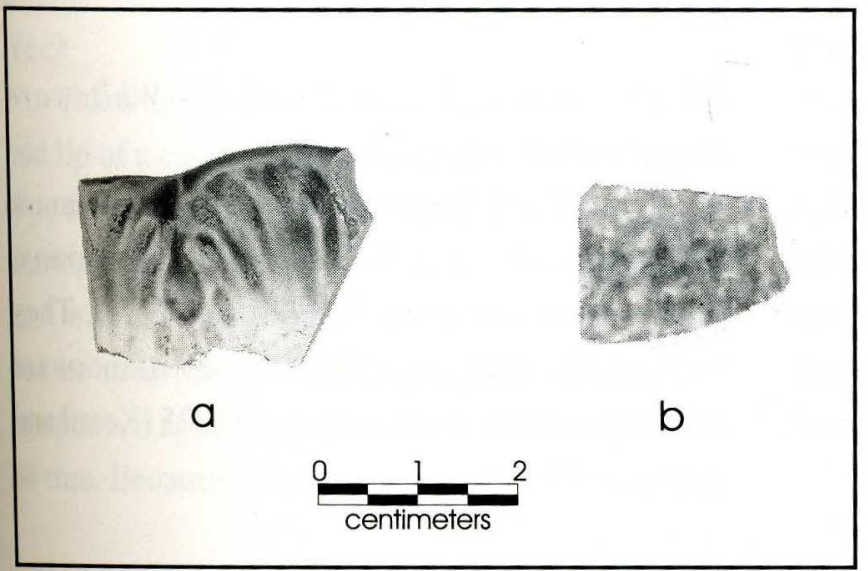

Figure 4-16. Dinnerware ceramics probably associated with the Burleson occupation: (a) 'cockle-edge' edgeware - UI 24 - Unit 1, Level 1; (b) spatterware - UI 25 - Unit 26, Level 1. 
category. Many of these pieces are small sherds that may be part of a piece whose decorations would determine more specifically a date well after the Burleson occupation.

\section{Unique Dinnerware Ceramic Items}

This section discusses an edgeware and five spatterware sherds that are probably associated with the Burleson occupation at 41HY37. In addition, the four sherds with identifiable makers' marks are described. These six items, along with selected pieces of decorated and undecorated whiteware, yellowware, handpainted, cut sponge, band and line, and stoneware are illustrated in Figures 4-16 through 4-19.

\section{UI 24 - Unit 1, Level 1 -Edgeware Sherd}

This specimen (see Figure 4-16a) is the only piece of edgeware observed, and may be an heirloom of the Burleson family. It is what Miller (1972) has identified as a cockle-edge (small shell with feather motif), dating to between 1795 and 1825. Three sherds of the same type were recovered from the site of San Marcos de Neve, a Spanish villa in existence from 1808 through 1812 . The villa was on the San Marcos River, approximately three miles downstream from modern-day San Marcos (Horrell 1999:Figure 10, 71, 119-120).

\section{UI 25 -Units 5, 11, 24 and 26-Spatterware Sherds}

A total of eight blue spatterware sherds were found (see selected specimen in Figure 4-16b). Spatterware was a popular decoration technique between 1800 and 1850. Although these pieces could have been an heirloom of later occupants, its age suggests there is a high probability that it is associated with the Burleson era at the site.
UI 26 - Feature 4, Surface - Transferware Sherd with Maker's Mark

This piece is the base of a vase or cup, with an English Registry mark used between 1842 and 1867. Letters and numerals stamped onto the vessel (refer to Figure 4-17a) indicate the following: " $\mathrm{R}$ " indicates the design was registered; the "IV" means that it is made of ceramics; the "Y" means it was registered in 1853; the " 8 " means it was registered on the eighth day of the month, the " 1 " indicates the individual or firm that registered it; and, the " $R$ " means it was registered in either August or September. It also has a " 6 " or "9" on the outer edge of its base, which is probably a design number (Kovel and Kovel 1991:405). In sum, the design for this piece was registered in England no earlier than August 8, 1853. Given the period of popularity of transferware, this specimen dates from the earliest, August 8, 1853 to around 1900. The printed design in pink is known as the 'horsecatcher' (Anne Fox, personal communication 2001).

\section{UI 27 - Shovel Test 8, Level 1 - Ironstone} Sherd with Maker's Mark

This sherd bears a partial maker's mark belonging to Morley and Company of Wellsville, Ohio (see Figure 4-17b). They used this mark on ironstone china manufactured from 1879 through 1884 (Kovel and Kovel 1991:73; Lehner 1988:305).

UI 28 - Shovel Test 4, Level 1 - Whiteware Sherd with Maker's Mark

This sherd bears a partial maker's mark belonging to F. Winkle and Company, Staffordshire, England (see Figure 4-17c). They printed this mark on the back of dinnerware manufactured from 1890 through 1925 (Kovel and Kovel 1991:70). 
UI 29 -Trench 1B, Level 1 - Ironstone Sherd with Maker's Mark

The printed backstamp on the base of this specimen is that of the British Royal Arms, with an oval central area and a unicorn on the right side (see Figure 4-17d). This particular design was used by J\&G Meakin, Hanley, Staffordshire, England after 1890. However, the four quadrants within the central oval were only inserted after 1937; thus, this specimen could not have been manufactured before 1937 .

\section{UI 38 - Unit 23, Level 4 - Decorated Whiteware}

Both salt glazing and painting appear on this specimen (see Figure 4-17e). It has an 'orange peel' exterior underneath a green paint, resembling the grassy surface in front of a fence. The fence has been painted in crisp, fine lines in gray and black over a smooth surface. The date of this specimen is indeterminate.

\section{UI 39 - Unit 16, Level 2 - Decalcomania}

This small rim sherd has a light green leaf pattern (see Figure 4-17f). The technique of using decals to imprint tablewares was popular from approximately 1890 to 1930 (Moir 1987:102).

\section{Other Ceramic Unique Items}

\section{UI 34 - Unit 6, Level 2 - White Clay Bottle Neck}

This fragmented specimen represents the neck and lip of a ceramic bottle designed for a stoppertype closure (see Figure 4-17g). Part of a maker's mark embossed on its neck is "..GH" and "..D", and with this little information, its maker could not be determined. Placed on a concentric ring template, it appears the interior neck diameter was $84 \mathrm{~mm}$. Because of its stopper-type closure design, this bottle would likely have been produced between about 1850 and 1900 .

Additional examples of dinnerwares found during the excavations are shown in Figure 4-18.

\section{Stoneware}

Selected pieces of stoneware recovered from various units are shown in Figure 4-19. They include examples of Albany slip, alkaline glaze, and Bristol glaze.

\section{Personal Items}

Doll and Game Parts, Toys

UI 30 - Unit 25, Level 1 - Porcelain Doll Leg

This specimen is a fragmented porcelain doll leg from a China Limb doll (Figure 4-20). China Limb doll legs, arms, and heads were made of porcelain, but the bodies were most often made of cloth. The porcelain extremities had holes in them so they could be sewn to the cloth bodies. China Limb dolls were popular from the 1850 s through around 1915. Germany was the main supplier of porcelain dolls for the U.S., but that abruptly subsided with the advent of war with Germany in WW I. However, WW I provided the impetus for developing or refining the manufacture of rubber, composition, and celluloid, and doll makers then began using these products instead of porcelain (Schroeder 1971; Tosa 1987:20). Because of their popularity, beginning around 1850 , there is a possibility this artifact could have belonged to the Burlesons.

\section{UI 40 - Unit 7, Level 1 - Toy Iron}

This specimen is a broken flat iron toy (Figure 4-21a) similar to one of the Parker Brothers 


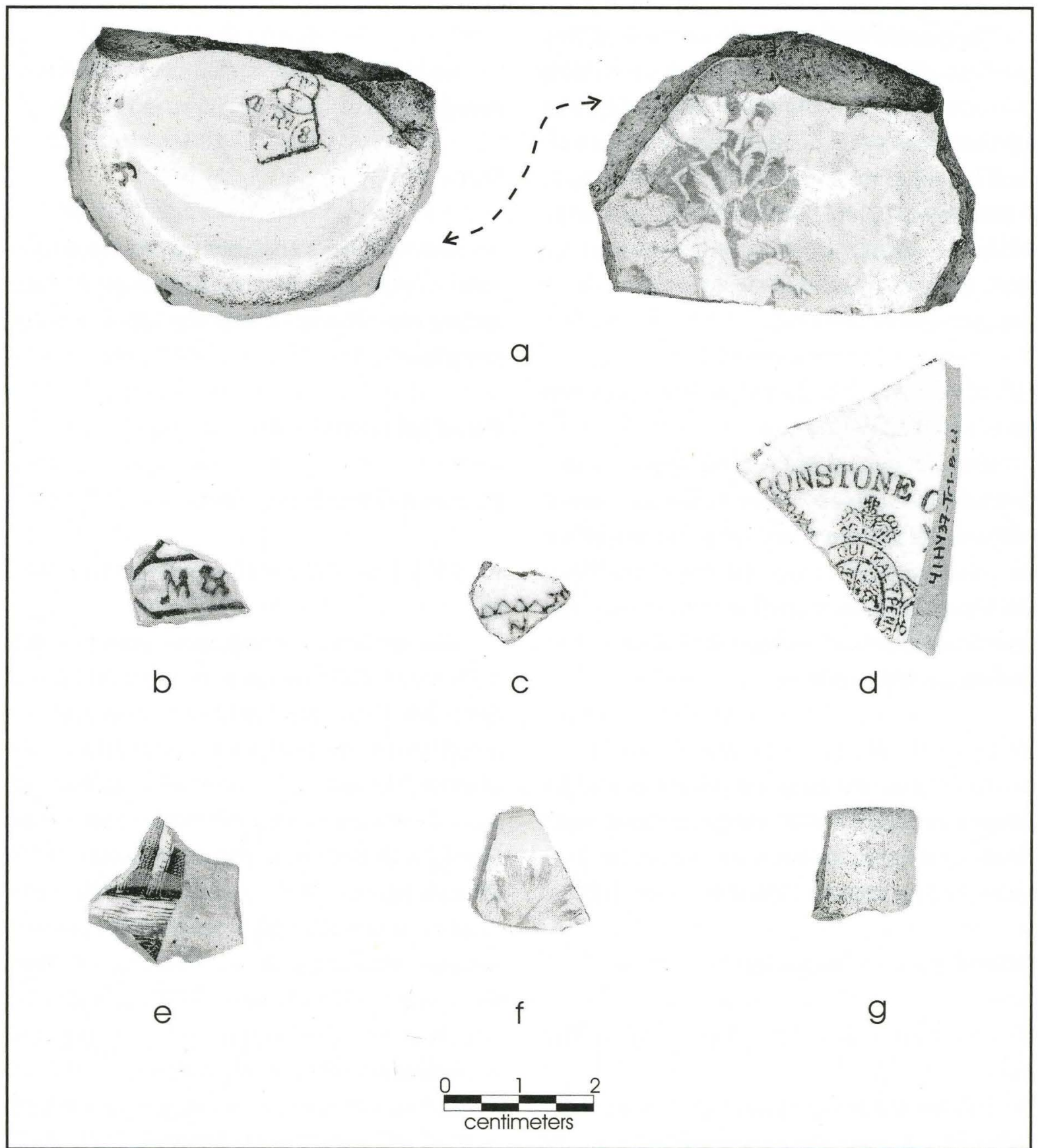

Figure 4-17. Unique dinnerware items: (a) 'horsecatcher' design transferware w/ English Registry mark - UI 26 - Feature 4, Surface (possibly Burleson era); (b) Morley and Co. ironstone - UI 27 - Shovel Test 8, Level 1; (c) F. Winkle and Co. whiteware - UI 28 - Shovel Test 4, Level 1; (d) J\&G Meakin Co. ironstone - UI 29 - Trench 1B, Level 1; (e) decorated whiteware - UI 38 - Unit 23, Level 4; (f) decalcomania - UI 39 - Unit 16, Level 2; (g) ceramic stopper type bottle neck - UI 34 - Unit 6, Level 2 . 


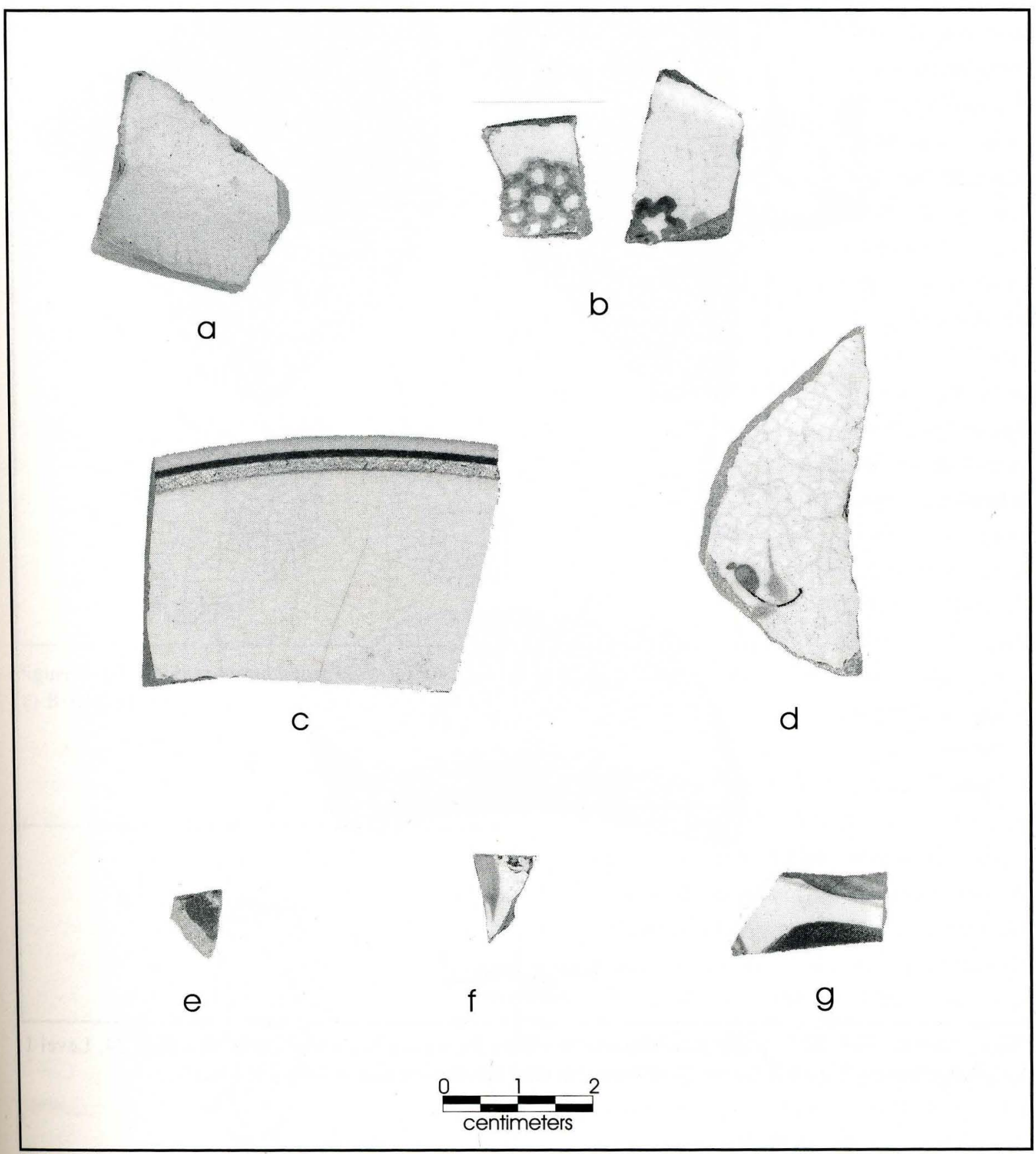

Figure 4-18. Selected ceramics recovered during this project: (a) yellowware (possibly Burleson era) - Unit 14, Level 1; (b) spongeware - Unit 23, Level 4; and Trench 1A, Level 1; (c) band and line Unit 26, Level 1; (d) handpainted sprig design (possibly Burleson era) - Trench 1B, Level 1; (e) handpainted - Unit 8, Level 2; (f) handpainted - Unit 12, Level 1; (g) handpainted - Unit 26, Level 1. 


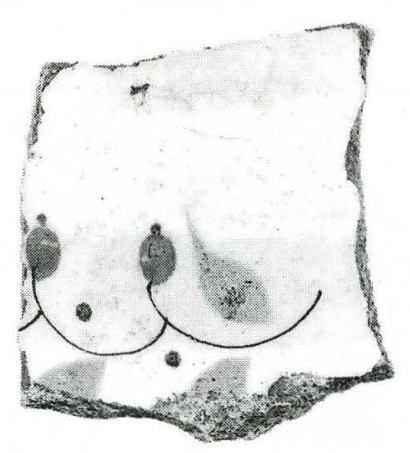

h

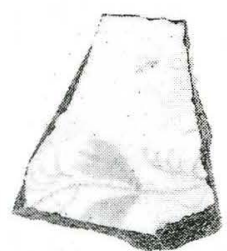

j

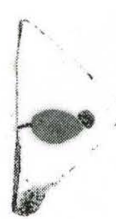

i

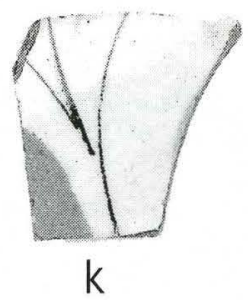

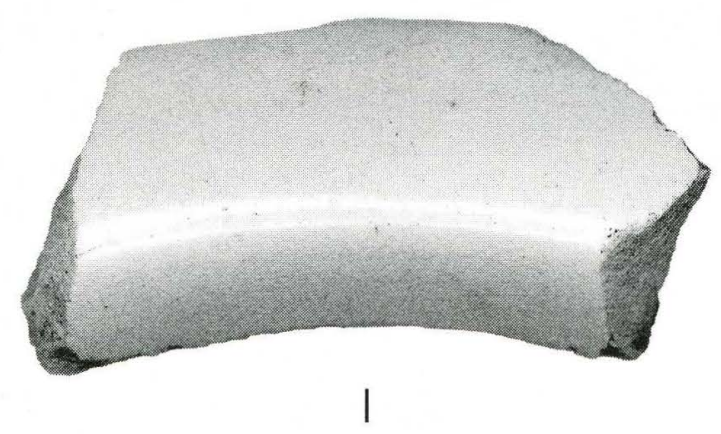

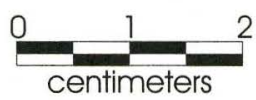

Figure 4-18 (continued). (h and i) handpainted - Unit 24, Level 2; (j) handpainted - Unit 24, Level 1; (k) handpainted - Unit 12, Level 3; (1) undecorated whiteware rim - Unit 23, Level 1.

Monopoly ${ }^{\circledR}$ board game pieces. Although an early homemade version monopoly board game was being played in the early 1900s, the Parker Brothers $®$ version with the metal game pieces was not developed until 1935 (Anspach 2001).

\section{Marble}

UI 35 - Unit 27, Level 1 - Ceramic Marble A Bennington Brown stoneware marble (Figure 4-21b) was found in Unit 27, Level 1. Bennington marbles apparently got their name 


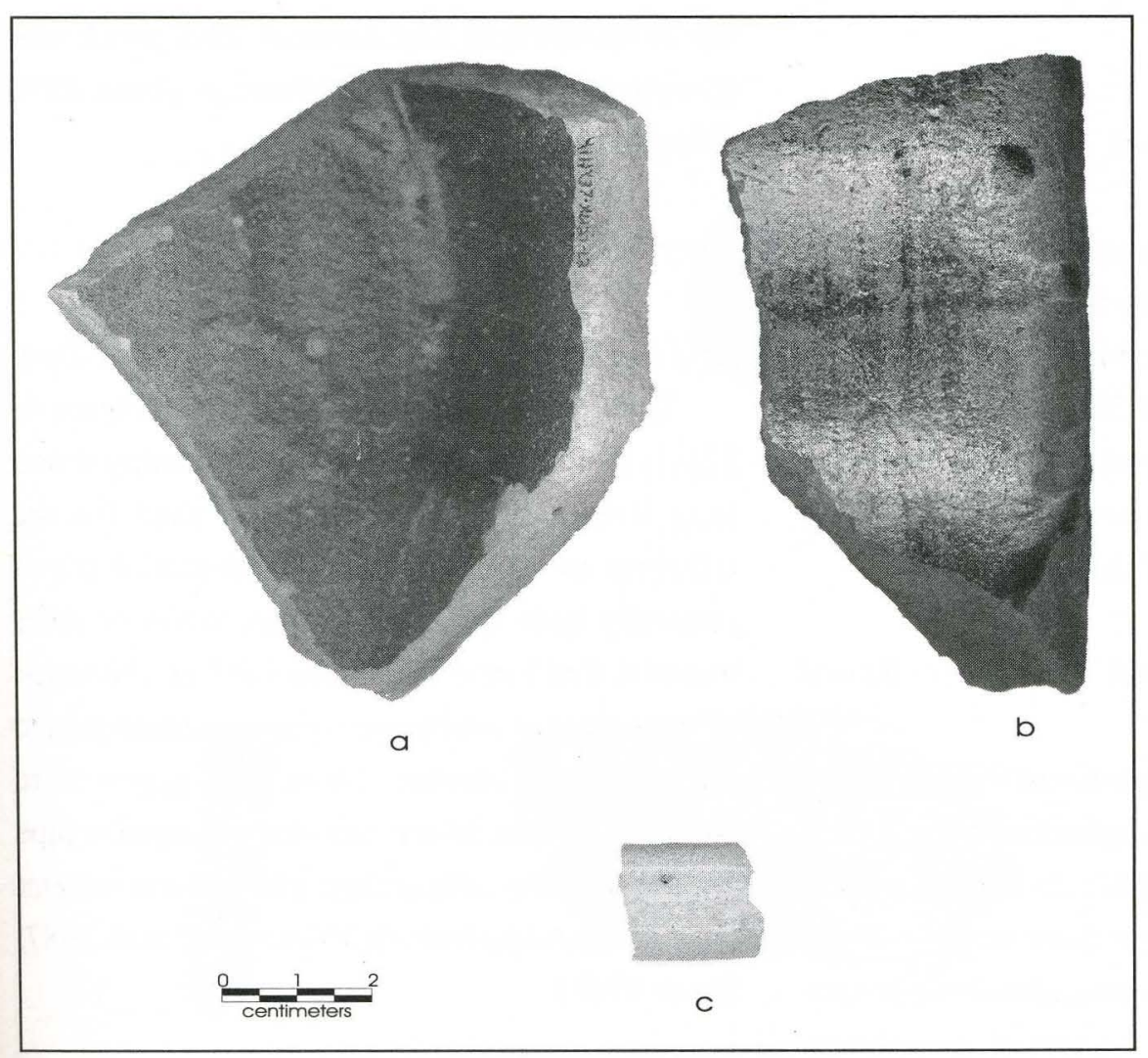

Figure 4-19. Selected stoneware sherds: (a) Albany slip; (b) alkaline glaze; (c) Bristol glaze. because the brown glaze looked the same as that used by the Bennington Pottery in Vermont. However, they were not produced there; they were imported from Germany, and were most popular in the United States around 1880 to 1900. Although Benningtons may have been around prior to 1880 (Carskadden et al. 1985; Randall 1971; Zapata 1997), they were probably not made, even in Germany,

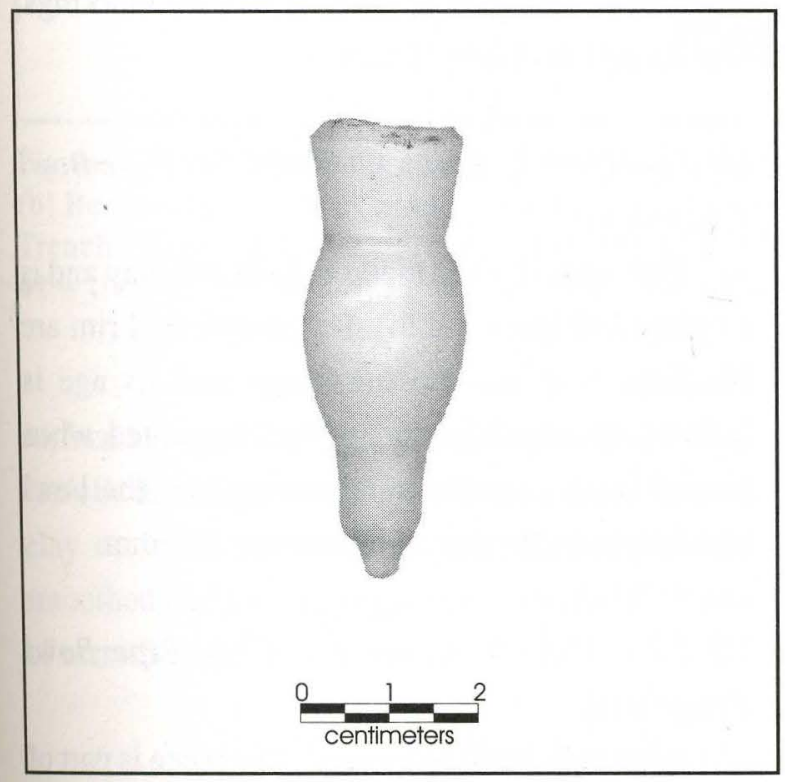

Figure 4-20. Porcelain doll leg, possibly belonging to the Burlesons; Unit 25, Level 1. before about 1870 (Alan's Marble Connection 2002). This particular specimen has a dark brown glaze with small 'roughsurfaced' areas and small areas where the glaze has not completely covered the surface; these flaws are presumably "...formed where the marbles touched one another while their glaze was still soft and they were being heated in the kilns" (Alan's Marble Connection 2002:14). Two Bennington Browns, one with the same darker brown colored glaze as the Burleson Cabin specimen, were found at the Pauly home site (41BX945) in downtown San Antonio, Texas (Zapata 1997). The Pauly home was occupied beginning from the early 1850s through 1975 (Wright 1997:16, 107). 
Writing-Related Items

\section{UI 37 - Unit 23, Level 1 - Slate Pencil Fragment}

A slate pencil fragment (Figure 4-21d) recovered is similar to those found on sites dating to the nineteenth and twentieth centuries (e.g., Burnett and Riskind 1984:399, 409). This piece could have been associated with the Burleson occupation; however slate pencils were still being used well after the turn of the century.

\section{UI 41 - Unit 22, Level 1 - Slate Board Fragment}

A small fragment of slate board (Figure 4-21e) may have been used in conjunction with a slate pencil found in Unit 23 (UI 37). As with the pencil, the board could have been associated with the Burleson occupation; however, slate boards were still being used well after the turn of the century.

\section{Household Items}

\section{UI 36 - Trench 1B, Level 1 - Bone Handle Fragment}

This specimen is polished on the exterior and has tooled 'screw-like' grooves on the interior (Figure 4-21c). It is dark gray from burning, has no maker's mark, and is too fragmented to render an opinion as to what instrument or tool it may have held. Bone handles are occasionally found on nineteenth century sites (e.g., Ing and Holt 1987:190-191).

\section{UI 42 - Unit 21, Level 3 - Clock Key}

Although heavily corroded, a small key resembling a clock key (Figure 4-21f) was recovered. No date can be established for this item, but a similar key of the same length that Meissner (1997:190-192) surmised was for a lock box or small padlock was found at the Czernecki home site (41BX893) in San Antonio. That home was occupied from about 1890 through about 1990 (Wright 1997:16, 50).

\section{Clay Tobacco Pipe Pieces}

\section{UI 31 - Unit 23, Level 3 - Kaolin Pipe Stem}

This fragmented kaolin pipe stem (Figure 422a) is from a self-stemmed pipe, meaning it was long stemmed, and meant to be used for the lifetime of the pipe. Short-stemmed pipes generally have stems made from wood or other material that could be trimmed off or shortened after a period of use by one smoker and then passed on to another smoker. Short stem pipes were common at inns where travelers enjoyed a pipe for a short while and then left it for a future traveler (e.g., Parsons and Burnett 1984; Assad et al. 1987; Sauer 1998).

This particular specimen is $72 \mathrm{~mm}$ in diameter and its drawhole is $23 \mathrm{~mm}$ in diameter. The drawhole is off center and blackened. It has two smoothed mold seams on opposite sides, running vertically from end to end. It has no markings, and its age is indeterminate.

\section{UI 32 - Unit 1, Level 1-Red Clay Pipe Bowl Fragment}

This specimen is made of bulk red clay and is unglazed (Figure 4-22b). Its interior and rim are blackened. It has no markings and its age is indeterminate. Although highly fragmented, when placed on a concentric ring template, the bowl opening is estimated to have been $202 \mathrm{~mm}$.

\section{UI 33 - Unit 9, Level 1 - Clay Pipe Bowl Fragment}

Although badly damaged, this piece is part of the rim and bowl of a bulk clay pipe (Figure 422c). It is unglazed, and unmarked. Its interior 


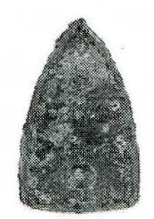

a

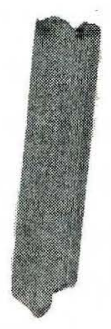

d

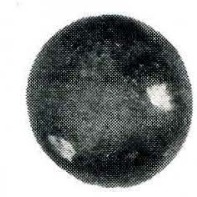

b

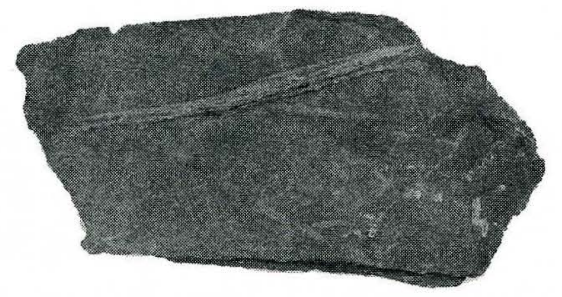

e
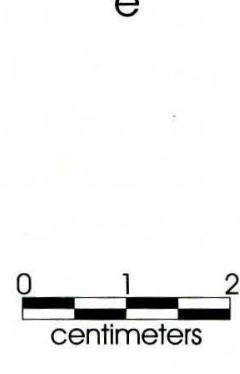

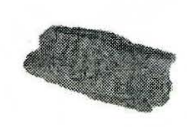

C

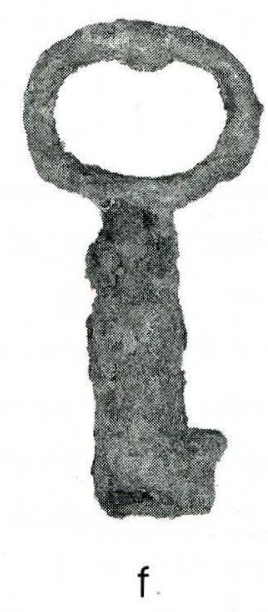

Figure 4-21. Games, household, and writing items: (a) toy iron game piece - UI 40 - Unit 7, Level 1; (b) Bennington Brown ceramic marble - UI 35 - Unit 27, Level 1; (c) bone handle fragment - UI 36 Trench 1B, Level 1; (d) slate pencil fragment - UI 37 - Unit 23, Level 1; (e) slate board fragment - UI 41 - Unit 22, Level 1; (f) clock key - UI 42 - Unit 2, Level 3.

surface has spalled. Although it is gray in color, it can't be discerned whether the gray is from natural clay or from smoking. Its rim has been well smoothed and tooled, suggesting a post- 1850 date of manufacture.

\section{Clothing Items}

\section{Buttons, Buckles and Snaps}

Non-Military

Two metal trouser snaps, five buckles, and 44 buttons were recovered during the excavations (Table 4-3). The buttons were made of ceramic ( $\mathrm{n}$ $=19)$, metal $(n=12)$, plastic $(n=5)$, shell $(n=3)$, 


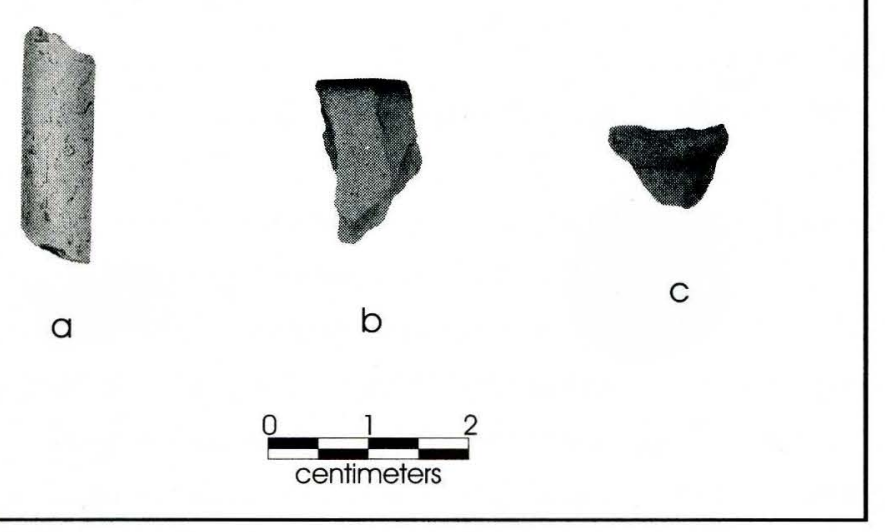

Figure 4-22. Smoking paraphernalia: (a) kaolin pipe stem fragment - UI 31 - Unit 23, Level 3; (b) red clay pipe bowl fragment - UI 32 - Unit 1, Level 1; (c) clay pipe bowl fragment - UI 33 - Unit 9, Level 1.

jet glass $(n=2)$, bone $(n=1)$, composition $(n=$ $1)$, and hard rubber $(n=1)$.

The primary focus of analyzing the buttons was to provide a relative age for each, with the goal of discerning a possible link to the occupation of the site by General Burleson and his immediate family, ca. 1845-1857 (Hays County Deeds and Records, Vol. C:454). An examination of Table 43 indicates that based upon their peaks in popularity within the U.S., there are 24 buttons and a buckle that could be from that period; they are summarized in Table 4-4, and illustrated in Figures 4-23 through 4-25. Most problematic are the ceramic buttons, which are commonly found on most late nineteenth and early twentieth century archaeological sites (Poole 1987:281; see, for example, Meissner 1997). Other selected buttons that post-date the Burleson occupation are shown in Figure 4-26, and metal buckles are shown in Figure 4-27.

\section{Military}

UI 42 - Unit 15, Level 1 - Staff Officer Button

The military button (see Figure 4-23) found in Unit 15, Level 1 during excavations around the
Burleson cabin replica is a Sanders 3-piece, Type III military button made of gilded brass. The size of this specimen is $14.8 \mathrm{~mm}$ in diameter, indicating it was made for either the smaller cuff, vest or jacket, versus a larger uniform coat or overcoat (Brinckerhoff 1972:1-2). The dome, or convex face of the button has the raised design of an eagle with upraised wings and a center shield with five wide lines, while holding three arrows in its right claw, and an oak leaf in its left claw. Nineteen fivepointed stars surround the eagle. Although a somewhat similar design appeared on army uniform buttons between 1792 and 1798 following the American Revolutionary War, they were made of a single piece of cast pewter, with only 13, 15, or 16 stars surrounding the eagle (Albert 1969:16). Therefore the Burleson cabin specimen has to be of later vintage. According to Brinckerhoff (1972:2), between 1846 and 1902, nearly all buttons used by the Army during this period have a raised American eagle on the front, but it is here that the differences are notable.

More accurately, Order Number 50 dated June 11,1832 , precisely prescribes the pattern and type of button found around the Burleson cabin replica as: "Button-gilt, convex, w/spread eagle and stars, and plain border." Scovill and company began producing this design in the 1830s for army staff officers, and continued its production through 1902 (Albert 1969:288-293; Wyckoff 1984:6468). Although this information is useful, it still only allows for placing the manufacture of the 
Table 4-3. Buttons, buckles, and snaps from $41 \mathrm{HY} 37$.

\section{Buttons, Buckles, and Snaps}

\begin{tabular}{|c|c|c|c|c|c|c|c|}
\hline Unit & Level & $\begin{array}{l}\text { Line } \\
\text { Size }\end{array}$ & Type & Material & $\begin{array}{l}\text { Production* } \\
\text { Period in U.S. }\end{array}$ & $\begin{array}{c}\text { Popularity* } \\
\text { Period in U.S. }\end{array}$ & Remarks \\
\hline 21 & 3 & 28 & flat rim; 4-hole & bone & $1800-1930$ & $1830-1890$ & broken; otherwise well preserved; probably nearer 1930 \\
\hline 12 & 1 & 14 & dish; 4-hole & ceramic & $1840-1930$ & $1850-1910^{* *}$ & (china button) \\
\hline 12 & 1 & 16 & disk; 4-hole & ceramic & $1840-1930$ & $1850-1910^{* *}$ & (china button) \\
\hline 14 & 2 & 16 & dish; 4-hole & ceramic & $1840-1930$ & $1850-1910^{* *}$ & (china button) \\
\hline 16 & 2 & 16 & dish; 4-hole & ceramic & $1840-1930$ & $1850-1910^{* * *}$ & (china button) \\
\hline 21 & 1 & 16 & dish; 4-hole & ceramic & $1840-1930$ & $1850-1910^{* *}$ & (china button) \\
\hline 23 & 4 & 16 & dish; 4-hole & ceramic & $1840-1930$ & $1850-1910^{* *}$ & (china button) \\
\hline 24 & 1 & 16 & dish; 4-hole & ceramic & $1840-1930$ & $1850-1910^{* *}$ & (china button) \\
\hline 24 & 1 & 16 & dish; 4-hole & ceramic & $1840-1930$ & $1850-1910^{* *}$ & (china button) \\
\hline 24 & 1 & 16 & dish; 4-hole & ceramic & 1840-1930 & $1850-1910^{* *}$ & (china button); lattice design \\
\hline 25 & 1 & 24 & dish; 4-hole & ceramic & $1840-1930$ & $1850-1910^{* *}$ & (china button) \\
\hline 25 & 1 & 24 & dish; 4-hole & ceramic & $1840-1930$ & $1850-1910^{* *}$ & (china button) \\
\hline 25 & 2 & 24 & dish; 4-hole & ceramic & $1840-1930$ & $1850-1910^{* *}$ & (china button) \\
\hline 26 & 1 & 16 & dish; 4-hole & ceramic & $1840-1930$ & $1850-1910^{* *}$ & (china button); lattice design \\
\hline 26 & 1 & 16 & dish; 4-hole & ceramic & $1840-1930$ & $1850-1910^{* *}$ & (china button) \\
\hline 26 & 1 & 16 & dish; 4-hole & ceramic & $1840-1930$ & $1850-1910^{* *}$ & (china button) \\
\hline 27 & 1 & 22 & dish; 4-hole & ceramic & $1840-1930$ & $1850-1910^{* *}$ & (china button) \\
\hline 30 & 2 & 28 & dish; 4-hole & ceramic & $1840-1930$ & $1850-1910^{* *}$ & (china button) \\
\hline 30 & 2 & 16 & dish; 4-hole & ceramic & $1840-1930$ & $1850-1910^{* * *}$ & (china button) \\
\hline TR-1A & 1 & 16 & dish; 4-hole & ceramic & $1840-1930$ & $1850-1910^{* *}$ & (china button) \\
\hline 6 & 1 & 22 & self shank; 4-hole & composition & $1875-1925$ & $1870-1900$ & Brown 1942:43 \\
\hline 12 & 2 & na & self shank & hard rubber & $1850-1915$ & $1870-1900$ & molded design w/traces of silver paint; no backmark suggests post-1870 date of manufacture \\
\hline 23 & 1 & 18 & dish & jet glass & $1830-1910$ & $1880-1910$ & broken; otherwise well preserved; probably nearer 1930 \\
\hline 23 & 3 & 34 & saucer; 4-hole & jet glass & $1830-1910$ & $1880-1910$ & concave face; broken \\
\hline 8 & 1 & & prong buckle & metal & unknown & unknown & \\
\hline 11 & 2 & 26 & trouser snap & metal & 1890-2001 & post-1890 & \\
\hline 14 & 2 & 28 & trouser snap & metal & 1890-2001 & post-1890 & \\
\hline 15 & 1 & & loop shank, 3-piece & metal & $1859-63 ; 1867-72$ & unknown & gilded brass, military, staff officer button for cuff, vest or small jacket \\
\hline 22 & 1 & & slide buckle & metal & unknown & unknown & \\
\hline
\end{tabular}


Table 4-3. Buttons, buckles, and snaps from 41HY37 (continued).

\begin{tabular}{|c|c|c|c|c|c|c|c|}
\hline \multicolumn{8}{|c|}{ Buttons, Buckles, and Snaps } \\
\hline & & Line & & & Production* & Popularity* & \multirow[b]{2}{*}{ Remarks } \\
\hline Unit & Level & Size & Type & Material & Period in U.S. & Period in U.S. & \\
\hline 23 & 1 & & tongue buckle & metal & unknown & 1860s\1870s? & similar to one found at Fort Richardson, Jacksboro, Texas (Westbury 1976:37, 39) \\
\hline 23 & 2 & 24 & loop shank, 3-piece & metal & $1830-1910$ & $1840-1890$ & glass button attachment \\
\hline 23 & 2 & 16 & loop shank, 3-piece & metal & $1823-2001$ & post-1823 & ball-shaped; inserted loop; cuprous \\
\hline 23 & 3 & 26 & disk; 4-hole; 2-piece & metal & $1870-2001$ & post- 1870 & ferrous; utility trouser; Olsen 1963:552 \\
\hline 23 & 3 & 26 & disk; 4-hole; 2-piece & metal & $1870-2001$ & post-1870 & ferrous; utility trouser; Olsen 1963:552 \\
\hline 23 & 3 & 30 & disk; 4-hole; 2-piece & metal & $1870-2001$ & post- 1870 & ferrous; utility trouser; Olsen 1963:552 \\
\hline 23 & 3 & & slide buckle & metal & unknown & unknown & garter or hose supporter \\
\hline 23 & 4 & 32 & disk; 4-hole; 1-piece & metal & $1870-2001$ & post- 1870 & ferrous; utility trouser; Olsen 1963:552 \\
\hline 23 & 4 & 32 & disk; 4-hole; 1-piece & metal & $1870-2001$ & post-1870 & ferrous; utility trouser; Olsen 1963:552 \\
\hline 23 & 4 & 30 & flatrim; 2-hole & metal & $1870-2001$ & pest-1870 & ferrous; self shank \\
\hline 23 & 4 & 32 & flatrim; 2-hole & metal & $1870-2001$ & post-1870 & ferrous \\
\hline 23 & 4 & 24 & flatrim; 2-hole & metal & $1870-2001$ & post-1870 & self-shank; brass w/lattice design; ferrous back; finely made; probably late $1800 \mathrm{~s}$ \\
\hline 26 & 2 & 22 & flatrim; 4-hole & metal & $1870-2001$ & post-1870 & ferrous \\
\hline TR-1B & 1 & 22 & slide buckle & metal & unknown & unknown & hammered brass; crossbar has been attached; not machine made; "US REGISTERED 1841" \\
\hline 5 & 1 & 24 & disk; 4-hole & plastic & $1870-2001$ & $1920-2001$ & post-1945 (Pool 1991:9) \\
\hline 9 & 1 & 24 & disk; 4-hole & plastic & $1870-2001$ & $1920-2001$ & post-1945 (Pool 1991:9); 'ribbed' design on back \\
\hline 9 & 1 & 16 & disk; 4-hole & plastic & $1870-2001$ & $1920-2001$ & post-1945 (Pool 1991:9) \\
\hline Fea. 4 & Surface & 28 & dish; 4-hole & plastic & $1870-2001$ & $1920-2001$ & post-1945 (Pool 1991:9) \\
\hline TR-1A & 1 & 28 & dish; 4-hole & plastic & $1870-2001$ & $1920-2001$ & post-1945 (Pool 1991:9) \\
\hline 1 & 1 & 12 & flat rim; 4-hole & shell & $1855-1930$ & $1900-1915$ & holes are irregular in size; hand made suggests pre-1850; iridescent pearl \\
\hline 21 & 3 & 14 & saucer; 4-hole & shell & $1860-1940$ & $1900-1915$ & hand-made w/punctated/decorated face suggests pre-1850; iridescent pearl \\
\hline \multirow[t]{3}{*}{ TR-1B } & 1 & 18 & tire; 4-hole & shell & $1855-1930$ & $1900-1915$ & machine cut, center turned on a lathe indicates post-1850; non-iridescent, freshwater mussel \\
\hline & & & o & & & & \\
\hline & & & & & & & * from Pool 1991:289; ** from Albert and Kent 1949:35 \\
\hline
\end{tabular}


Table 4-4. Non-military buttons that could date to the Burlesons' occupation of the site, 1845-1857 (see also Table 4-3).

\begin{tabular}{|c|c|c|c|}
\hline \multirow{2}{*}{ Button Material } & Period of Popularity in the U. S. & Unit(s) & Level(s) \\
\hline Metal & Post-1823 & 23 & 2 \\
\hline Metal & $1840-1890$ & 23 & 2 \\
\hline Shell & Pre-1850 & 1 & 1 \\
\hline Shell & Pre-1850 & 21 & 3 \\
\hline Shell & Post-1850 & 11 various units & 1 and 2 \\
\hline Ceramic (n $=19)$ & $1850-1910$ & & \\
\hline
\end{tabular}

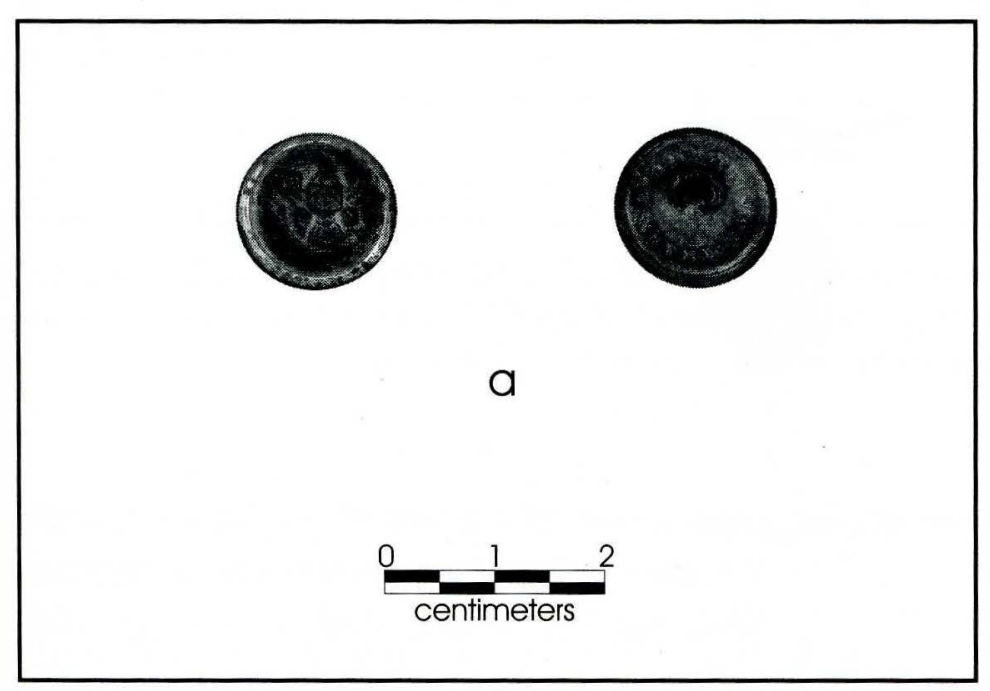

Figure 4-23. This military button, found in Unit 15, Level 1, was manufactured for Horstman Brothers \& Co. in Philadelphia sometime between 1859 and 1872 , for a general staff officer's cuff, vest, or jacket.

Figure 4-24. This brass slide buckle or clasp, with a U. S. Design date of 1841 , could be associated with the occupation of the site by General Burleson, ca. 18481851; found in Trench 1B, Level 1. 


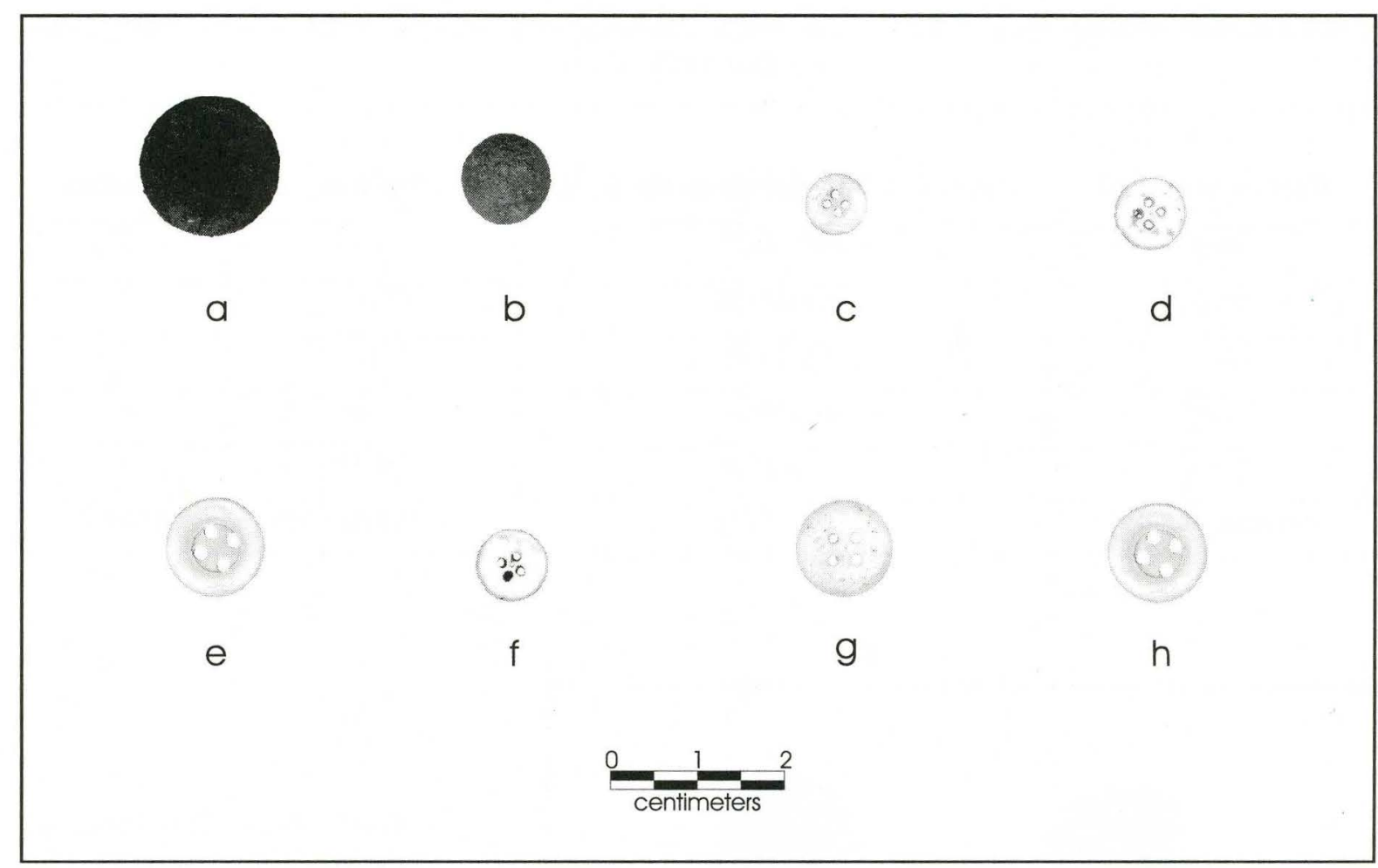

Figure 4-25. Buttons that could be from the Burleson occupation: (a, b) metal - Unit 23, Level 2; (c) shell - Unit 1, Level 1; (d) shell - Unit 21, Level 3; (e) shell - Trench 1B, Level 1; (f) ceramic - Unit 21, level 1; (g) ceramic - Unit 12, Level 1; (h) ceramic - Trench 1A, Level 1.

button within a relatively broad and approximated time frame of 60+ years (1830s-1902).

Therefore, it was further examined for additional evidence of its antiquity. The Burleson cabin button's design is known as a Line Eagle Device. It was issued to enlisted soldiers from 1833 through about 1865 , and purchased by officers from 1833 through about 1902 (Brinckerhoff 1972:3-4). The difference between those designed for enlisted versus officers is that on officer buttons, five-pointed stars in various numbers surround the eagle (see for example, Albert 1969:289). The design between 1833 and 1872 allowed for vertical lines in the center shield, but between 1872 and 1902, seven to thirteen stars were added within the upper section of the shield, called the chief (Brinckerhoff 1972:6-7). An examination of the face of the Burleson cabin specimen indicates its center shield is vertically lined, but most notably there are no stars, thus indicating a date of manufacture between 1832 and 1872. Although these distinguishing characteristics further define its age to within a forty year period, it's back was examined for a backmark.

'Backmarks' are inscriptions that commonly appear on the rear of buttons. They can help identify the name and location of either the button manufacturer, or the supplier. Because the manufacturer and suppliers changed the names of their companies, or identification marks through time, or they went out of business, backmarks are useful in telling the age of buttons (Albert 1969:8). 


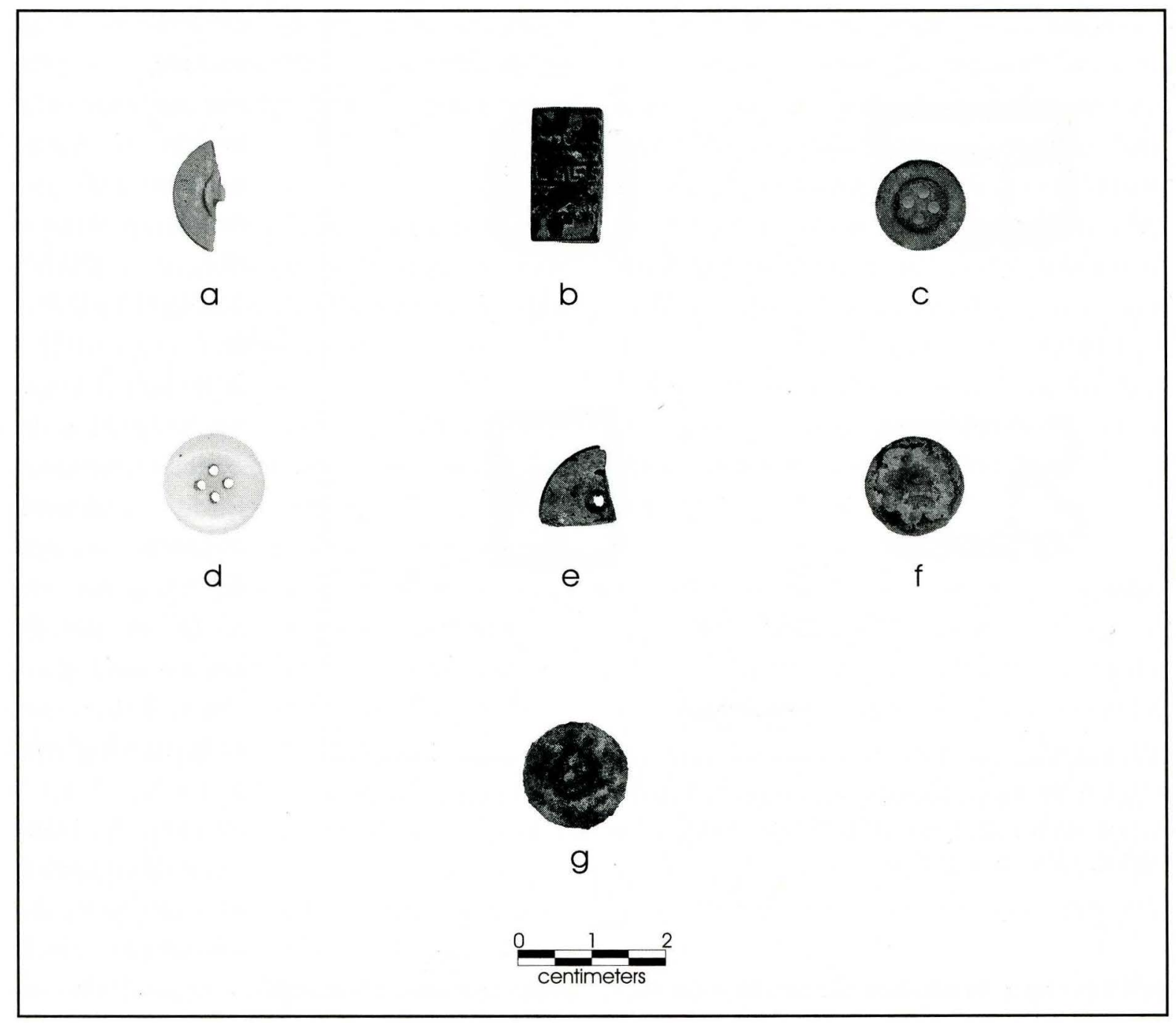

Figure 4-26. Buttons and snaps that post-date the Burleson occupation: (a) bone - Unit 21, Level 3; (b) hard rubber - Unit 6, Level 1; (c) composition - Unit 6, Level 1; (d) plastic - Unit 5, Level 1; (e) jet glass - Unit 23, Level 3; (f) metal snap - Unit 11, Level 2; (g) metal snap - Unit 4, Level 2.

Stamped on the back of this button are the letters "HORSTMANN BROS PHILA." W. H. Horstmann of Philadelphia was a major military contractor of uniforms and insignia beginning in the 1820s (Brinckerhoff 1972:4-5, 36; see also Bazelon 1997). They used this backmark for buttons manufactured between 1859 and 1863, and then again between 1867 and 1893 (Bazelon 1997:145; Brinckerhoff 1972:36; Johnson 1948).
Therefore, in summary and by process of elimination, it was determined that this button was manufactured for Horstmann Brothers \& Company of Philadelphia either between 1859 and 1863 , or between 1867 and 1872. As such, it is definitely not associated with the occupation of the site by General Burleson or his immediate family. Nor is it likely to have been associated with the subsequent landowner, Cephas Thompson. Although he owned the property between 1857 and 1866, he apparently did not live 


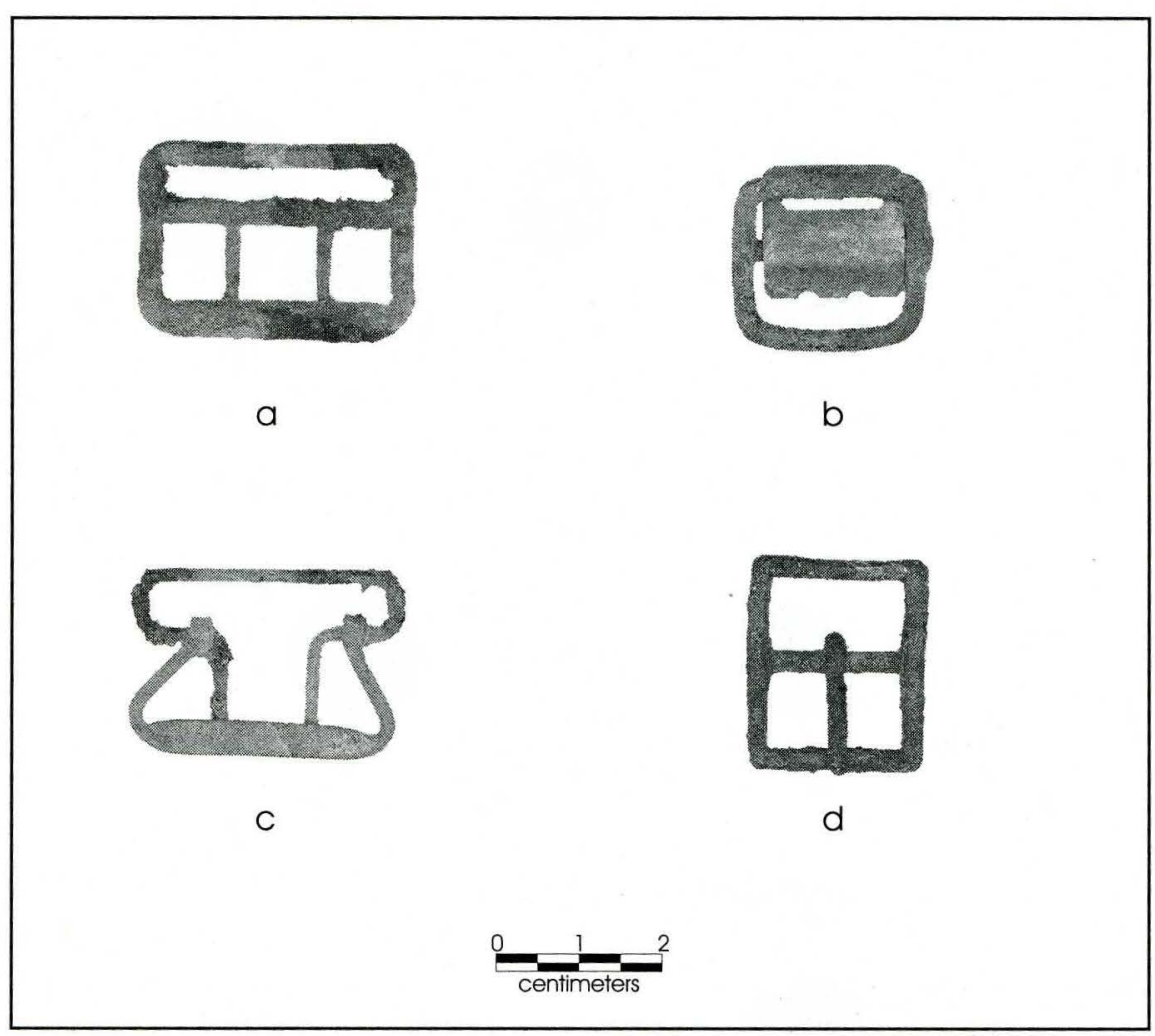

Figure 4-27. Metal buckles: (a) tongue buckle - Unit 23, Level 1; (b) slide buckle - Unit 22, Level 1; (c) slide buckle - Unit 23, Level 2; (d) prong buckle - Unit 8, Level 1. crossbar has been melded to the circular body. The buckle is backmarked with the following stamps: "US DESIGN REGISTERED 898 D ‘ 1841." Although it could not be found in the available literature, its backmark suggests it was designed for the military in 1841 . Its interior diameter is $\checkmark$ inch. With such an early date of design, and the Army's tendency to issue standard equipment over many years, this specimen could

on the property. In addition, the button is that of a Union Army officer; Thompson served in the Confederate Army during the Civil War (Brandimarte et al. 1999). It was designed for a cuff, vest, or small jacket to be worn by an officer of the U. S. Army general staff. Much like today's army, officers of the general staff in the 1800 s were designated as such because they served as staff officers in general, and not in the combat arms branches such as infantry, artillery, engineer, and ordnance. The officer could have held any of the ranks, from Lieutenant through General.

\section{Metal Slide Buckle (or Clasp)}

A small, round brass slide buckle or clasp was recovered from Trench 1-B (see Figure 4-24). Its represent General Burleson's occupation of the site (ca. 1848-1851).

Hardware, Harness, Tools, and Construction Items

Nails, Bolts, and Screws

Nails can be classified into three main categories: 1) handwrought, 2) cut with handhammered heads or cut with machine-made heads, or 3) wire. Handwrought nails were commonly used until the $1800 \mathrm{~s}$, falling off in popularity with the introduction of cut nails. Cut nails with handhammered heads were popular in use between ca. 1790 and 1825 , followed by cut nails with machine-made heads, commonly used from ca. 
1825 to present. Though they were introduced prior to the 1850 s, wire nails did not become the dominant type until the 1890s (Nelson 1968:1$10)$.

A total of 1,148 nails, bolts, and screws were recovered (Appendix D). Of those, 1,033 were either cut or square nails, 104 were round nails, and 11 were either bolts or screws.

In undisturbed contexts from welldocumented structures, data on cut, square, and round nails can be useful (e.g., Jurney 1988). However, the Burleson Cabin replica was constructed with square nails ordered from Indiana and shipped to a store near Blanco in the 1960s (Isabel Gutierrez, Sr., personal communication September 2000). With this information, no further analysis of the nails was undertaken.

\section{Other Metal Items}

Various pieces of metal were recovered from the surface as well as in 24 different excavation units and shovel tests (Appendix E). Much of it was rusted scrap, and either undatable, or clearly modern construction debris from the cabin and nearby gondola station. None of the pieces could be identified as having a probable association with the Burleson occupation. Nevertheless, a few items are of interest, and could possibly be associated with that era. They are listed in Table 4-5 and are shown in Figures 4-28 through 4-30. Some of the items are similar to those shown in the 1895 Montgomery Ward Catalogue (Montgomery Ward and Co. 1969:327-328, 380, 392).

They include: 1) a wardrobe lock; 2) a copper key with "....ERRY \& CO.," an eagle, and a picture of a key stamped into it; 3) a window sash latch; 4) a hand-forged cotter pin; 5) a hand-forged 'opposite clinch' iron bracket; 6) two hand-forged chain links that are of irregular shape and lengths; 7) a hand-forged halter bolt; 8) a hand-forged harness ring; and 10) an apparently hand-forged ferrule for a hoe, hay fork, shovel, or other tool.

Table 4-5. Selected metal items.

\begin{tabular}{|c|c|c|c|c|}
\hline Item & Category & Figure & Unit/Level & Similar Item Depicted In: \\
\hline Wardrobe Lock & Household Hardware & $4-28 a$ & Feature 4/surface & Montgomery Ward Catalogue \\
\hline Key & Household Hardware & $4-28 b$ & Trench $1 \mathrm{~A}$ & \\
\hline Window Latch & Household Hardware & $4-28 \mathrm{c}$ & $22 / 1$ & \\
\hline Cotter Pin & Barn Hardware & $4-29 a$ & $2 / 1$ & \\
\hline Clinch iron & Barn Hardware & $4-29 b$ & $22 / 1$ & \\
\hline Chain Links & Barn Hardware & $4-29 c$ & $23 / 2$ & \\
\hline Ferrule & Farm Tools & $4-29 d$ & $12 / 3$ & Montgomery Ward Catalogue \\
\hline Halter Bolt & Horse/Mule Harness & $4-30 a$ & $10 / 1$ & Montgomery Ward Catalogue \\
\hline Harness Ring & Horse/Mule Harness & $4-30 b$ & $10 / 1$ & Montgomery Ward Catalogue \\
\hline Harness Snap & Horse/Mule Harness & $4-30 c$ & $11 / 1$ & \\
\hline
\end{tabular}



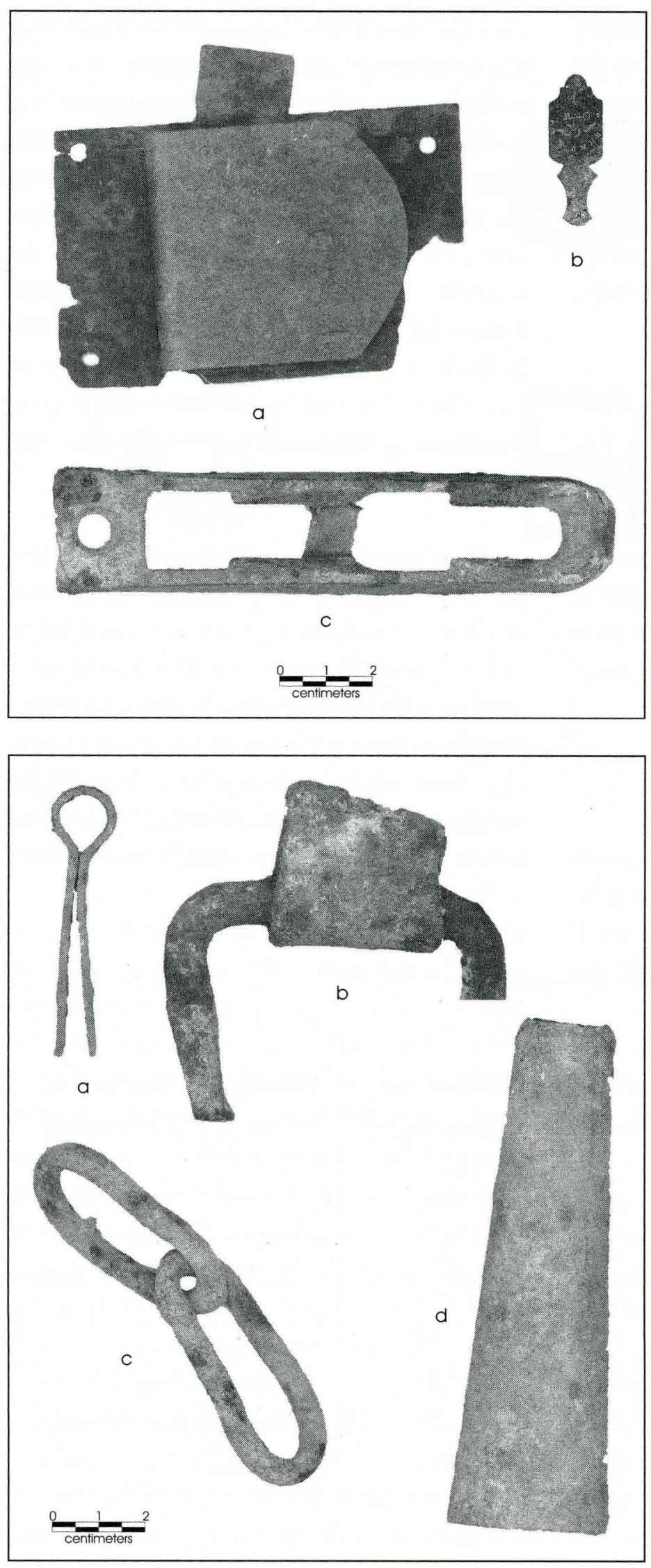

Figure 4-28. Metal household hardware: (a) wardrobe lock Feature 4, surface; (b) copper key - UI 42 - Trench 1A; (c) window latch - Unit 22, Level 1.
Figure 4-29. Barn hardware and farm tools: (a) cotter pin - Unit 2, Level 1; (b) clinch iron - Unit 22, Level 1; (c) forged chain links Unit 23, Level 2; (d) ferrule for rake, hoe, or shovel - Unit 12 , Level 3. 


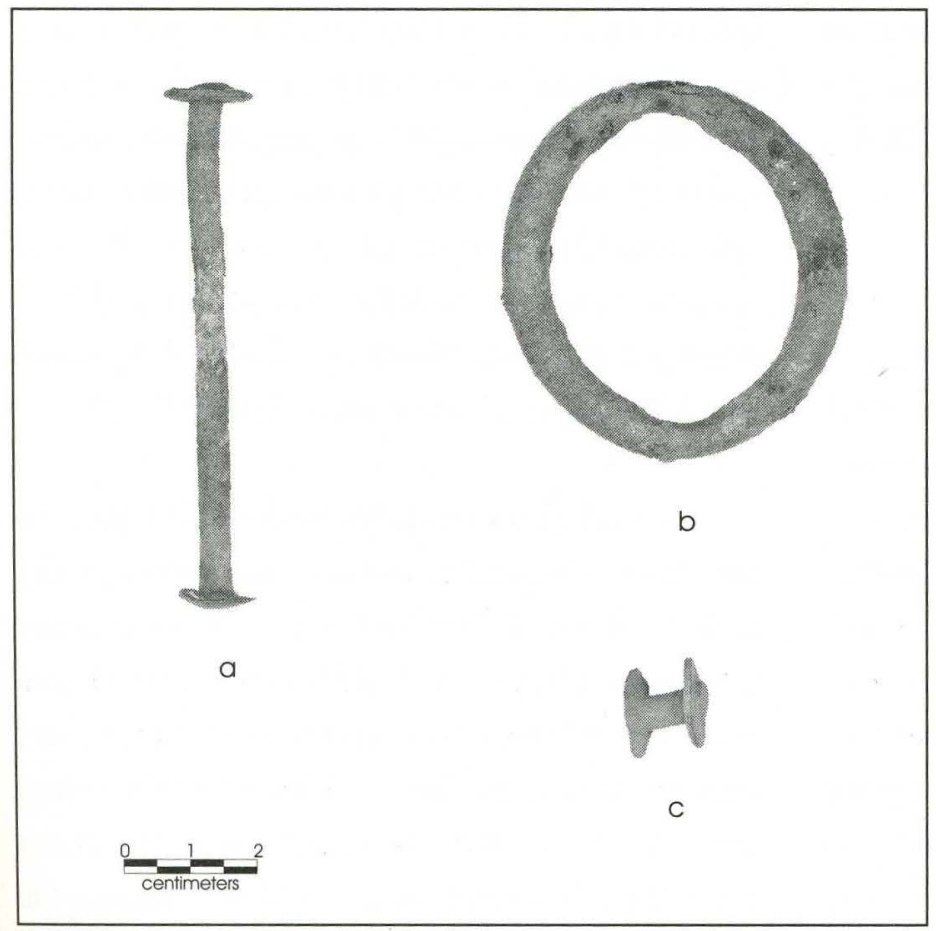

Figure 4-30. Horse/mule harness: (a) halter bolt - Unit 10, Level 1; (b) harness ring - Unit 10, Level 1; (c) harness snap - Unit 11, level 1 .

\section{Prehistoric Artifact Analysis}

In total, 2,265 chipped-stone artifacts were recovered and analyzed. During the analysis, the artifacts were subdivided into the following classes: projectile points $(n=4)$, bifaces $(n=25)$, unifaces $(n=21)$, utilized flakes $(n=31)$, cores $(\mathrm{n}=6)$, complete flakes $(\mathrm{n}=598)$, incomplete flakes $(n=1,553)$, and heat spalls $(n=27)$.

\section{Projectile Points}

Four incomplete and untypable projectile points were recovered during the exacavations, and are described individually and shown in Figure 4-31.

\section{UI 43 - Unit 2, Level 1-Small Arrow Point}

UI 43 (Figure 4-31a) is the distal portion of a small arrow point, made of gray chert found in
Unit 2, Level 1. Its base has been snapped off from impact during use. Although untypable, its blade is not unlike many Perdiz points commonly found on Late Prehistoric, Toyah phase sites in Central Texas (e.g., Nickels 2000). The Toyah phase generally spans the period from A.D. 1400 throughA. D. 1700 (Collins 1995).

UI 44 - Unit 21, Level 4 Scallorn-Like Arrow Point

UI 44 (Figure 4-31b) is an incomplete specimen most closely resembling a Scallorn point dating to the Austin phase of the Late Prehistoric period, approximately A.D. 750 through A. D. 1400 (Collins 1995). It was recovered from Unit 21, Level 4. Its long blade has been resharpened to give it a slightly concave shape, and it is serrated along one lateral edge. It is made of tan chert and both its distal tip and base appear to have been snapped off from impact during use.

\section{UI 45 - Unit 14, Level 1- Point Barb}

UI 45 (Figure 4-31c) was found in Unit 14, level 1. It is a barb made of light gray chert and has been fractured twice from indeterminate causes. It is too badly broken to presume a type or time period.

\section{UI 46 - Unit 1, Level 2 - Archaic-Like Dart Point \\ UI 46 (Figure 4-31d) exhibits the most heavy patina cover of the four points recovered. It was found in Unit 1, Level 2. Although untypable, from what remains of its base, it is Archaic-like in appearance, possibly Pedernales or Gower.}


Pedernales points are thought to be from the Late Archaic period (A D. 750-2000 B. C.), and Gower from the Early Archaic period (4050-6850 B. C.) (Collins 1995).

\section{Other Chipped Stone}

Because of their apparent disturbed context (discussed at the end of this chapter), a detailed analysis of the chipped stone assemblage was not conducted. However, on a macro scale, limited observations can be made. Four features uncovered at 41HY37 were described as firecracked rock and ash over $3 \mathrm{ft}$. in diameter, probable cooking features. These, along with a large quantity and wide variety of stone tools (see Appendix G) imply that the site was used as an open campsite (Schiffer 1975). And, although problematic because of their fractured condition, the four projectile points recovered suggest that $41 \mathrm{HY} 37$ was occupied during the Late Prehistoric and part of the Archaic. Thus, the entire assemblage was compared with $41 \mathrm{WN} 88$, a large open campsite in relatively undisturbed context in Wilson County, approximately $60 \mathrm{~km}$ south of 41HY37. $41 \mathrm{WN} 88$ has yielded radiocarbon dates and projectile points indicating the site was occupied during the Late Prehistoric and Late Archaic periods (Nickels 2000; Raymond Mauldin, personal communication 2001).

In order to statistically compare data from the two sites, adjusted residuals and a contingency table were used. The first step in a contingency table is to separate the table into row and column variables, tabulate the individual cell values, and sum the rows and columns. Then expected values are calculated. In doing so, we assume that the percentage of each type or class will remain the same as the overall percentages for each type or class. The next step in a contingency table analysis is to examine the difference between the observed value and expected value of each cell. However, these numbers may not be useful, depending on
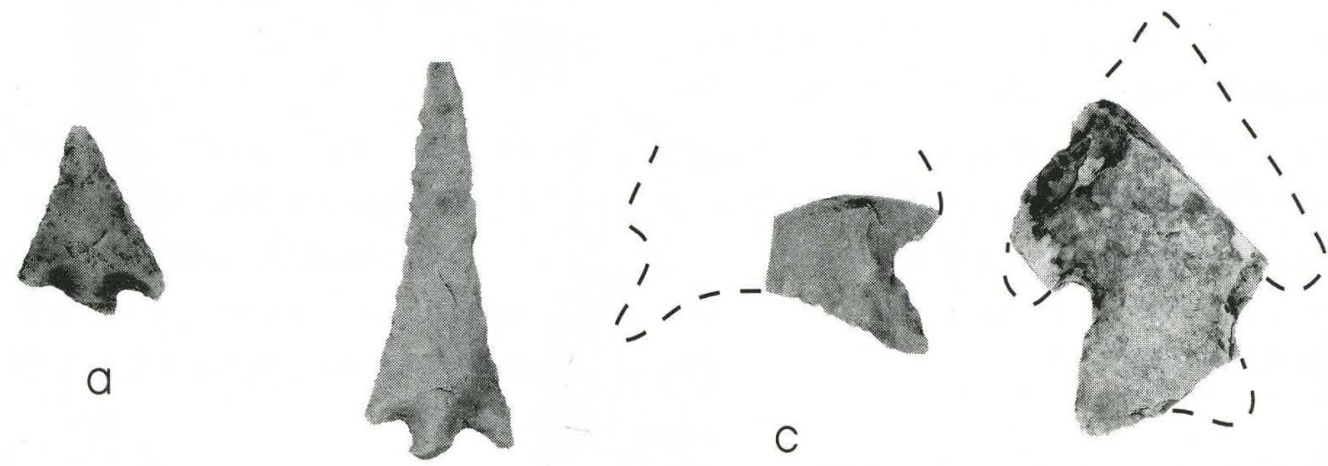

b
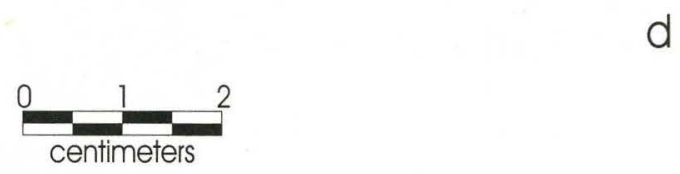

Figure 4-31. Projectile points: (a) Perdiz-like arrow point - UI 43 - Unit 2, Level 1; (b) Scallorn-like arrow point - UI 44 - Unit 21, Level 4; (c) fragmented barb - UI 45 - Unit 14, Level 1; (d) Archaiclike dart point - UI 46 - Unit 1, Level 2. 
the sample size of each type or class to be compared. The variation in sample size can be offset by examining the difference between the observed and expected values in each cell and then dividing this number by the square root of that cell's expected value. The result is called the standardized residual. Although standardized residuals are not easily interpreted in statistical terms, if they are divided by their estimated variance for each individual cell, then the interpretation is much more straightforward. The result of this calculation is called the adjusted residual. Adjusted residuals have the same distribution as a z-score, and thus can be easily interpreted in terms of significance. For purposes of this analysis, a 5 percent level of confidence is used, which equates to an adjusted residual of greater than 1.96 or less than 1.96. Table 4-6 summarizes the contingency table analysis.
Initially, a contingency table analysis conducted comparing the broad categories of cores, total flakes, and tools revealed no statistically significant differences in the chipped stone assemblage between $41 \mathrm{HY} 37$ and that of $41 \mathrm{WN} 88$, an intact, large open campsite in a riverine environment. Presumably then, without further detailed analysis of the chipped stone assemblage at $41 \mathrm{HY} 37$, it could be surmised that the subsistence and settlement patterns of the groups who occupied these two sites were similar (Nickels 2000).

However, when the broad category of flakes is divided into complete and incomplete, significant differences are revealed. Most importantly, a review of Table 4-6 indicates that there is a significantly greater quantity of incomplete flakes at $41 \mathrm{HY} 37$, and a slightly

Table 4-6. Contingency table comparison of data from two open campsites.

\begin{tabular}{|c|c|c|c|c|c|}
\hline & Cores & $\begin{array}{c}\text { Complete } \\
\text { Flakes }\end{array}$ & $\begin{array}{c}\text { Incomplete } \\
\text { Flakes }\end{array}$ & Tools & Totals \\
\hline \multicolumn{6}{|l|}{ Observed } \\
\hline 41HY37 & 6 & 598 & 1,553 & 81 & 2,238 \\
\hline $41 \mathrm{WN} 88$ & 26 & 4,471 & 8,179 & 365 & 13,041 \\
\hline Expected & & & & & \\
\hline 41HY37 & 5 & 742 & 1,426 & 65 & \\
\hline $41 \mathrm{WN} 88$ & 27 & 4,327 & 8,306 & 381 & \\
\hline \multicolumn{6}{|l|}{$\begin{array}{l}\text { Adjusted } \\
\text { Residuals }\end{array}$} \\
\hline $41 \mathrm{HY} 37$ & 0.66 & -7.02 & +6.07 & +2.13 & \\
\hline $41 \mathrm{WN} 88$ & -0.66 & +7.02 & -6.07 & -2.13 & \\
\hline
\end{tabular}


greater number of tools. The significantly greater quantity of incomplete (broken) flakes is most probably a result of the construction and other numerous recent human activities that have occurred on the site in the Historic period. A subjective evaluation of the tools category is that they are also heavily fragmented (e.g., see Figure 4-31, projectile points).

\section{Vertebrate Faunal Remains}

\author{
Barbara A. Meissner
}

\section{Methods}

A total of 164 vertebrate faunal remains, weighing $210.26 \mathrm{~g}$, was recovered during the project. The bone was identified to the most specific taxon possible using the comparative collection at the Center for Archaeological Research of the University of Texas at San Antonio, as well as several reference texts (Balkwill and Cumbaa 1992; Cohen and Serjeantson 1996; Gilbert et al. 1981, 1990; Hildebrand 1955; Hillson 1986; Olsen 1960, 1964, 1968; Sobolik and Steele 1996). Identifications were conservative, i.e., bone that appeared to be cow-sized was not identified as Bos taurus unless it could be differentiated from Bison and Equus species. One exception to this is that all saw-cut bone of cow size was tentatively identified as Bos (cattle), under the assumption that horse and bison would not be butchered in this fashion during the time the farm was occupied. All bone was weighed. Evidence of exposure to heat was noted on all bone. Element, portion of element, side, evidence of immaturity, butcher marks, and pathologies were noted on bone identified to the order taxonomic level. After the analysis, the bone was bagged by unit and level. Bone identified to at least the order taxonomic level was bagged separately and included in the unit-level bags.

\section{Analysis}

A list of identified taxa is shown in Table 4-7 with counts and weights. A complete provenienced list of all data recovered from the bone is in Appendix I.

A total of seven genera was identified, representing 11 percent $(n=18)$ of the total. Catfish (Ictalurus sp.) is the most common identified bone, constituting 39 percent of identified bone, and cattle the next most common taxa (see Table 4-7), with 33.3 percent of the identified bone.

Evidence of exposure to heat can indicate whether bone was routinely thrown into the fire as a disposal method. Normally, cooking of meat, even over an open fire, will only smoke-stain or char the bone. The duration and intensity of heating necessary to calcine bone is considerable. It is unlikely to occur during routine cooking (Lyman 1994:388-389). In this collection, only 8.5 percent $(n=14)$ of the bone showed evidence of heat alteration, indicating that burning of bone was probably incidental at the site.

\section{Discussion}

The bone in this collection is highly fragmented. Only 11 percent $(n=18)$ was identified to the genus taxonomic level. Seventyseven percent $(n=126)$ of the total could be identified only as mammal. The small number of identified bone severely limits the inferences that can be drawn from this analysis. However, a few observations can be made. The presence of the pig teeth, for instance, implies that these animals were raised and butchered on the site. The sawcut cattle bone may have been butchered on-site as well, but is more likely to have been purchased 
Table 4-7. Taxon list of faunal materials recovered at the Burleson Homestead.

\begin{tabular}{|c|c|c|c|}
\hline \multirow{2}{*}{ Taxon } & Common Name & Count & Weight (g) \\
\hline Artiodactyla & Deer, sheep, goat & 2 & 5.04 \\
\hline Bos taurus & Cattle & 6 & 73.27 \\
\hline Bovinae & Cattle/bison & 1 & 11.30 \\
\hline Caprinae & Sheep or goat & 1 & 12.11 \\
\hline Didelphis virginiana & Opossum & 1 & 1.00 \\
\hline Lepus californicus & Blacktailed jackrabbit & 1 & 3.32 \\
\hline Rodentia & Rodents & 3 & 0.61 \\
\hline Sigmodon hispidus & Hispid cotton rat & 2 & 0.68 \\
\hline Sus scrofa & Domestic pig & 5 & 5.91 \\
\hline & Unidentified Mammal & 126 & 92.89 \\
\hline & Total Mammal & 148 & 206.13 \\
\hline Colinus virginianus & Bobwhite quail & 1 & 0.27 \\
\hline Columbidae & Pigeons and doves & 1 & 0.11 \\
\hline & Unidentified Bird & 3 & 1.93 \\
\hline & Total Bird & 5 & 2.31 \\
\hline Ictalurus sp. & Catfish & 7 & 1.37 \\
\hline & Unidentified Fish & 4 & 0.45 \\
\hline & Total Fish & 11 & 1.82 \\
\hline
\end{tabular}

from a professional butcher. There is a bovid phalange and a tarsal of a sheep or goat, implying that at least some butchering of these animals took place on the site. The presence of opossum and jackrabbit may be incidental, but it is possible that these animals were hunted and were part of the diet. This is also true of the quail and pigeon or dove identified. Weniger has noted, however that while opossum was a popular addition to the diet, jackrabbit was usually considered too tough for European tastes (Weniger 1997:155-156).

One other observation is the small sample size itself. The bone appears to be scattered refuse, suggesting that none of the units excavated in this project encountered a trash pit. In summary, only
164 bones were collected during this project, of which only 18 (11 percent) were identified to the genus taxonomic level. Due to the small sample size, this collection is only able to hint at the nature of the meat diet on the farm, and how that meat was acquired. 


\section{Summary and Conclusions}

David L. Nickels

\section{Site Integrity}

\section{Vertical Distribution of Artifacts}

A total of 95 levels were excavated either in 3-x-3-ft. squares, or in shovel tests. Chipped stone, presumably from the prehistoric period, as well as historic artifacts, were recovered in all 95 levels. Appendix $\mathrm{H}$ provides a listing of the mixed assemblages within the 95 possible proveniences. There is no single provenience that does not have chipped stone mixed with historic artifacts.

Although there are 16 levels with either glass, ceramics, or porcelain that could be associated with the Burleson occupation, 14 of the 16 also had modern artifacts, and the remaining two had at the earliest, post-1900 artifacts.

There are 55 levels with artifacts dating to between 1850 and 1900 . However, 47 of those 55 also had modern artifacts, five contained at least post-1900 artifacts, and the remaining three had metal or glass of an indeterminate age.

In sum, there does not appear to be any level within the 95 excavated that does not contain a mixed assemblage.

\section{Horizontal Distribution of Artifacts}

In an effort to discern discrete horizontal patterns across the site, I lumped the 32 excavation units into three groups: 1) units north of the cabin (Units 2, 4, 5, 7, 10, 16, 25, 27, and 29); 2) units south of the cabin (Units 1, 3, 6, 8, 11, 13, 14, 18, 20, 21, 23, 30, Trench 1A, and Trench 1B); and 3) units around Feature 4 (Units 9, 12, 15, 17, 19,
$22,24,26$, and 28). The distribution of diagnostics from these units was examined using a contingency table (for explanation, see Prehistoric Artifact Analysis section). Table 4-8 presents the results of our analysis based on the number of cases with at least one diagnostic within the unit; more than one occurrence of a diagnostic of the same period was still treated as a single case.

An examination of Table 4-8 reveals that statistically there are no significant differences in the distribution of unique period artifacts across the site; the distribution is homogeneous, and the artifact assemblage is mixed.

\section{Excavated Features}

Four of the eight features uncovered during this project were firecracked rock cooking ovens or hearths, and although historic artifacts were mixed within them, they presumably are prehistoric in age. Two features were determined to be naturally occurring rock formations, and one turned out to be a modern mortar mixing area. However, by far the most intriguing is Feature 4, a carved bedrock ledge (see Figure 4-4). One feasible opinion rendered suggests it may have been used as the base of a platform or 'derricklike' device with ropes to haul water up from the springs. Other thoughts are that it may have had something to do with cooking, or with melting lead for shot. Although numerous professional and avocational archaeologists examined the feature and offered plausible explanations, no artifactual data was recovered, nor any archival data obtained, to explain its existence. 


\section{Artifacts Probably, or Possibly Associated with the Burleson Era}

As stated previously, one of the research questions focused on whether or not artifacts associated with the Burleson occupation of the site could be distinguished within the archaeological record. As discussed earlier in this chapter, there appears to be no spatially discrete 'Burleson component,' as the entire assemblage is mixed. In total there are 301 individual artifacts that could be associated with the Burleson era. However, in most cases it would be problematic to imply that they are because the individual pieces generally were popular not only during the 1840s and 1850s, but also for many decades following.

\section{Glass Bottles}

Five pieces of glass bottles that could date to the Burleson era are Unique Items 1 through 5 (see Figure 4-13). They are bottles that were generally manufactured from about 1850 through 1900.

\section{Ceramic Dinnerware and Stoneware}

There are several pieces of dinnerware ceramics and stoneware vessels that could have belonged to the Burlesons. The earliest sherds within the assemblage are a piece of blue, cockled edgeware (see Figure 4-16a), diagnostic to between 1795 and 1825, and eight pieces of spatterware, dating to between 1800 and 1850 (one specimen shown in Figure 4-16b). The edgeware piece may be an heirloom of the Burleson family, but could also be related to the only recorded earlier occupation in the area at the time, San Marcos de Neve, a Spanish villa in existence on the San Marcos River from 1808 through 1812. Spatterware was a popular decoration technique between 1800 and 1850. Although these pieces could have been an heirloom of later occupants, their age suggests there is a high probability that it is associated with the Burleson era at the site.

Other pieces that were manufactured as early as the 1840 s are nine pieces of undecorated, white porcelain, two pieces of cut sponge ware (see Figure 4-18b) and a handpainted sherd with sprig designs (see Figure 4-18d).

Most common within the assemblage are undecorated whiteware sherds (see Table 4-2). Although whiteware was popular in the $1850 \mathrm{~s}$, it was also used well into the twentieth century, and is still being produced today. A few pieces of stoneware found have Albany, alkaline, and salt glazes (see Figure 4-19) that were popular in the $1850 \mathrm{~s}$, but were also commonly used through around 1900. Two other sherds that were likely produced between 1850 and 1900 is a piece of yellowware (see Figure 4-18a), and a piece of transferware (see Figure 4-17a).

\section{Buckle and Buttons}

A small, round brass slide buckle, or clasp with a backmark indicating it was most probably designed for the military in 1841 was found (see Figure 4-24). With such an early date of design, and the Army's tendency to issue standard equipment over many years, this specimen could represent General Burleson's occupation of the site (ca. 1848-1851).

Table 4-4 lists 24 non-military buttons that could have belonged to the Burleson family. Most problematic are 19 of the ceramic type buttons, that although were popular in the U.S. beginning around 1850 , are also the type most commonly found on historic sites dating to the end of the 
nineteenth century. Two shell buttons recovered were popular before 1850 , and a third beginning in the 1850s (see Figure 4-25 c-e). Finally, one metal button could be as early as 1823 , and a second likely dates from 1840 to 1890 (see Figure 4-25 a and b).

Metal Hardware, Harness, and Tools

None of the metal recovered could be identified as having a probable association with the Burleson occupation. Nevertheless, while a few items are of interest, and could possibly be associated with that era (Table 4-5, see Figures 428 through 4-30), some are similar to items found 40 years later in the 1895 Montgomery Ward Catalogue. They include: 1) a wardrobe lock, 2) a copper key with “...ERRY \& CO.," an eagle, and the picture of a key stamped into it, 3) a window sash latch, 4) a hand-forged cotter pin, 5) a handforged 'opposite clinch' iron bracket, 6) two handforged chain links that are of irregular shape and lengths, 7) a hand-forged halter bolt, 8) a handforged harness ring, 9) a cuprous harness snap, and 10) an apparently hand-forged ferrule for a hoe, hay fork, shovel, or other tool.

\section{Miscellaneous Items}

\section{Broken Doll Leg}

The broken leg of a China Limb Doll (see Figure 4-20) is from a doll that was popular from the 1850s through around 1915. Because of their popularity beginning around 1850 , there is a possibility this artifact could have belonged to young Elizabeth Burleson.

\section{Slate Board and Pencil}

Pieces of a slate board and slate pencil (see Figure 4-21 d and e) recovered are similar to those found on sites dating to the nineteenth and twentieth centuries. These pieces could have been associated with the Burleson occupation, as Edward Burleson had built a school near the site; however slate pencils were still being used well after the turn of the century.

\section{White Clay Bottle Neck}

A fragmented neck and lip of a ceramic bottle designed for a stopper-type closure was found. Because of its stopper-type closure design, this bottle would likely have been produced between about 1850 and 1900, and thus could possibly be associated with the Burleson occupation (see Figure 4-17g).

\section{Window Glass and Square Nails}

As discussed previously in this chapter, the window glass sample was problematic and thus cannot be used for dating. Square nails were purchased for the cabin replica in the 1960s, and thus it is not feasible to imply that any of the square nails could be from the original Burleson cabin. 


\section{CHAPTER 5}

\section{Summary and Recommendations}

\section{Britt Bousman}

As discussed in Chapter 3, the specific goals of the archaeological investigations were to determine the original location of the Burleson cabin, locate and identify the remains of any outbuildings used by Burleson at this site, and amass additional archival and archaeological information that could be used to further interpret the locality. These goals were developed in order to assist Texas State University-San Marcos in addressing the recommendations set out by Volz's (1999) architectural assessment of the Burleson replica. It should be stated that the university has undertaken this project in order to better preserve the unique archaeological and historical resources surrounding Spring Lake and to develop a plan to help educate the public about the unique historical role played by the San Marcos Springs.

\section{Summary}

The results of the archival and archaeological research clearly demonstrate that the original location of the Burleson cabin was on the ridge above Spring Lake and that the replica was erected on the general site of the original cabin. The 1855 map prepared for the probation of Edward Burleson's will (see Figure 2-4), Koch's 1881 bird's-eye view of San Marcos (see Figure 2-5), and the early photographs visibly and incontestably illustrate Burleson's cabin on the ridge above the San Marcos Springs (see Figures 2-6 and 2-7). However, both the Gutierrez interview (see Appendix J) and archaeological investigations indicate that the replica cabin was not constructed on the original foundation of Burleson's cabin, but that the original foundation and chimney stones were used to construct the replica's foundation and chimney. Also, the Gutierrez interview revealed the final history and dispensation of the original cabin, and his record was fully supported by the archaeological evidence. Furthermore, no archaeological evidence provided any information regarding the location of the outbuilding identified on the early twentieth century photographs (see Figure 2-7). This is not surprising, as we used the location of the replica cabin as a reference point to look for evidence of the outbuildings and the replica is not in the original location. Nevertheless, any outbuildings would have been either under the gondola station or destroyed by construction of the street behind (northwest) of the gondola station.

Even though over 300 artifacts were identified that probably date to this period, the excavations failed to locate unmixed deposits that date to the mid-nineteenth century. The types of artifacts 
grouped by functional categories dating to the Burleson era are listed in Table 5-1.

The high frequency of domestic (kitchen, clothing, children) artifacts ( 84 percent) supports the hypothesis that this was the general location of a mid-nineteenth century residence. Of the 22 identifiable mammal bones recovered, at least 12 (55 percent) were from domestic species, and this again supports an early historic farming residential pattern. However, the low frequency of farmrelated artifacts suggests that the location of a barn or other work-related activities did not take place in great frequencies at this location. The low number of bones $(n=148$ mammal and $n=11$ fish) suggests that the excavated areas did not sample the location(s) where butchering occurred. At farms butchering would often take place near the barns and apparently these activities were not conducted at this location, and the location of a barn and related activities is unknown from either the historical or archaeological evidence.

While the exact use of Feature 4 is still debatable, the above-related patterns suggest that a cooking use for this feature is well within the range of possibilities and it would support a residential use of this locale. This feature is unique within the Texas historic archaeological record. A review of site reports from across the state and informal inquiries to archaeologists throughout the state failed to provide a single comparable example. Also, even though the patterns are not statistically significant, there is a slightly higher frequency of pre-1850 artifacts near this feature than in the remainder of the site. It appears that Feature 4 probably dates to the Burleson occupation, although this cannot be stated conclusively. All the other features can be related to the construction of the replica cabin and do not provide any useful information regarding the use of this location by Burleson and his family.

The archival and archaeological investigations have provided important new information about the Burleson Homestead (site 41HY37). Unfortunately, unmixed deposits from this occupation appear to be absent and evidence of the original cabin has certainly been destroyed by Aquarena Center construction and other activities. However, a single feature was discovered that possibly dates to the Burleson period of occupation.

Table 5-1. Artifacts that probably date to the mid-nineteenth century, grouped by gross functional categories.

\begin{tabular}{|c|c|c|}
\hline Category/Activity & Count & Percentage \\
\hline Kitchen & 23 & 38 \\
\hline Clothing & 25 & 41 \\
\hline Hardware & 10 & 16 \\
\hline Children & 3 & 5 \\
\hline Total & 61 & \\
\hline
\end{tabular}




\section{Recommendations}

In regard to the existing structure (replica) and the locale, Volz (1999:5) offered four recommendations:

1) preserve the replica and interpret it as a 1960 facsimile of the original homestead;

2) remove the replica and provide interpretive signage near the existing monument;

3) remove the replica and interpret the site using archaeological and historical research; or

4) remove the replica and reconstruct the original cabin, outbuildings and landscape. Recent damage to the replica's porch caused by a falling tree limb influences but does not eliminate the options available to Texas State University.

The historical and archaeological evidence presented in this report should be used to provide better and more accurate information to the public, and it seems reasonable to incorporate the 'cooking facility'

(Feature 4, see Figure 4-4) into the interpretive program. However, some care should be made to protect this feature from visitors and vegetation, as the limestone is fragile and easily broken. Perhaps a trail or path could be constructed down to the feature that directs people adjacent to the feature, but restricts their access to the feature. Also, vegetation that grows on Feature 4 should be removed, as their roots will eventually contribute to the slow degradation of the rock.

Other specific locations on the landscape that could be used include the reconstructed water well (Figure 5-1). Apparently this is on the site of the original well, although not reconstructed accurately. Still, the well provides additional historic context to the site. The replica Spanish mission should be removed. No documents or archaeological evidence were found that relates to the specific location of these activities or any structures, and it is highly unlikely that the ridge was where the Spanish lived between 1755-1757. Furthermore, it is also highly unlikely that the Spanish constructed any but simple jacal (mud and wood) dwellings while at the San Marcos River. The original location of Burleson's cabin is at the gondola station and reportedly was completely dismantled. It is highly unlikely that any evidence of this original cabin has survived and could be

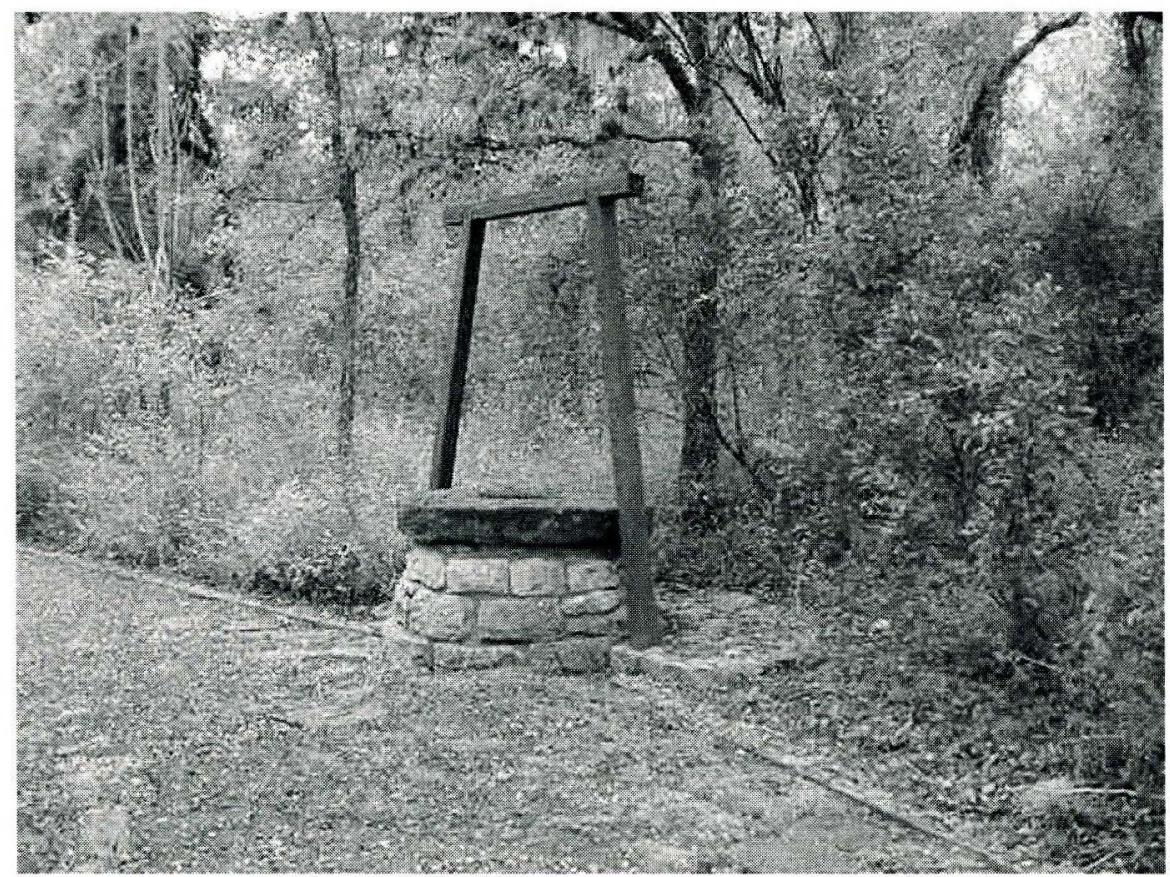

Figure 5-1. Water well, although reconstructed inaccurately, provides 
used for interpretive purposes. Also, little would be gained by conducting further archaeological excavations, as intact, unmixed deposits do not appear to have survived. If the gondola station was removed, then this area should probably be tested, to be sure.

As the replica is not truly historic, there is no apparent legal or preservation need to maintain this structure. However, the presence of a replica does offer great interpretive benefits, especially if new signage could be provided that offers a more accurate view of events and people who lived and visited this locale. For example, Placido, the Tonkawa chief, was a regular visitor to the Burleson cabin and he apparently was at the cabin the night a group of Comanche stole horses from the stockade adjacent to Burleson's cabin (Wilbarger 1985 [1889]:58-59). This and other stories could be effectively presented to the public on appropriate (weatherproof, decay-resistant) signs near the cabin. The presence of a replica provides a strong visual device to portray the stories of this site. However, it may be more cost effective to construct an accurate replica from new materials instead of restoring the existing structure. Furthermore, preserved on post cards and newspaper photographs, a remarkable visual record exists of the original cabin and these could also be used on display signs.

In conclusion, a great deal has been learned concerning the Burleson ownership and use of the San Marcos Springs, but unfortunately, little intact evidence survives. That which does survive, such as Feature 4, should be preserved and used to provide a more accurate and full understanding of the locale when Edward Burleson settled the site and helped establish the community of San Marcos. 


\section{References Cited}

Alan's Marble Connection

2002 Electronic document, <http://marblealan.com/nonglass $>$, accessed 9 January 2002, 2:27 p.m. US/Central.

Albert, A. H.

1969 Record of American Uniform and Historical Buttons. Bayertown Publishing, Bayertown, Pennsylvania.

Albert, A. H., and K. Kent

1949 The Complete Button Book. Appledore, Stratford, Connecticut.

Ansell, R. F.

1932 "Burleson Homestead Marker Was Dedicated Here Last Thursday." San Marcos Daily Record 8 July. San Marcos, Texas.

Anspach, R.

2001 Electronic document, <http://www.antimonopoly.com/game_evolution.html>, accessed 23 January 2002, 8:40 a.m. US/Central.

Arnn, J. W., III, and K. Kibler

1999 Archaeological Survey and Geomorphological Assessment for the Proposed Spring Lake Water Line, Hays County, Texas. Technical Report No. 41. Prewitt and Associates, Austin.

Atterbury, P. J.

1979 European Pottery and Porcelain. Main Street, Clinton, New Jersey.

Bagdade, S., and A. Bagdade

1991 Warman's English \& Continental Pottery \& Porcelain. $2^{\text {nd }}$ ed. Krause Publications, Iola, Iowa.

Balkwill, D. M. and S. L. Cumbaa

1992 A Guide to the Identification of Postcranial Bones of Bos taurus and Bison bison. Canadian Museum of Nature, Ottawa.

Barber, E. A.

1976 The Pottery and Porcelain of the United States and Marks of American Potters. Feingold and Lewis, New York.

Barnes, Virgil E.

1974 Geologic Atlas of Texas, Seguin Sheet. Bureau of Economic Geology, University of Texas at Austin.

Bazelon, B. S.

1997 Horstmanns: The Enterprise of Military Equipage. Privately printed, Camp Hill, Pennsylvania. 
Berendt, J.

1989 The Zipper. Esquire viii(5):42.

Birkeland, P. W.

1974 Pedology, Weathering, and Geomorphological Research. Oxford University Press, London.

Black, S. L.

1986 The Clemente and Herminia Hinojosa Site, 41JW8: A Toyah Horizon Campsite in Southern Texas. Special Report No. 18. Center for Archaeological Research, University of Texas at San Antonio.

Blair, F.

1950 The Biotic Provinces of Texas. Texas Journal of Science 2(1):93-117.

Blake, M. E., and M. D. Freeman

1998 Nineteenth-Century Transfer-Printed Ceramics from the Texas Coast: The Quintana Collection. Prewitt and Associates, Inc., Austin.

Boes, T. C.

1994 Archeological Testing and Monitoring at San Marcos (A. E. Wood) Fish Hatchery, Hays County, Texas. Texas Parks and Wildlife Department Public Lands Division, Cultural Resources Program. Austin.

Bolton, H. E.

1914 Athanase de Mézières and the Louisiana-Texas Frontier 1768-1780, Vol. I \& II. Arthur H. Clark, Cleveland.

1970 [1915] Texas in the Middle Eighteenth Century: Studies in Spanish Colonial History and Administration. Originally published in 1915 as Volume 3 of The University of California Publications in History. Published in 1970 as Texas History Paperback in cooperation with the Texas State Historical Association. University of Texas Press, Austin.

Bracht, V.

1848 Texas in 1848. Translated from the German by Charles Frank Schmidt. Naylor Printing Co., San Antonio, Texas.

Brandimarte, C.

1999 A History of Aquarena Springs. Unpublished manuscript, The Practice of Public History (HIST 5345G), Fall Semester 1998, Public History Program. Manuscript on file, History Department, Southwest Texas State University, San Marcos, Texas.

Brinckerhoff, S. B.

1972 Metal Uniform Insignia of the Frontier U.S. Army, 1846-1902. Museum Monograph No. 3. Arizona Historical Society, Tucson.

Brown, D. F.

1942 Button Parade. Wallace-Homestead Co., Des Moines, Iowa.

Brune, G.

1981 The Springs of Texas, Vol. I. Branch-Smith, Fort Worth.

Burnett, R. E.

1981 Archeological Testing, Fanthorp Inn State Historic Site, 41GM79, Grimes County, Texas. Texas Parks and Wildlife Department, Historic Sites and Restoration Branch, Austin. 
Campbell, T. N., and T. J. Campbell

1985 Indian Groups Associated with Spanish Missions of the San Antonio Missions National Historical Park. Special Report No. 16. Center for Archaeological Research, University of Texas at San Antonio.

Carskadden, J., R. Gartley, and E. Reeb

1985 Marble Making and Marble Playing in Eastern Ohio: The Significance of Ceramic, Stone, and Glass Marbles in Historic Archaeology. Proceedings of the Symposium on Ohio Valley Urban and Historic Archaeology 3:86-96.

Cohen, A., and D. Serjeantson

1996 A Manual for the Identification of Bird Bones from Archaeological Sites. Revised ed. Archetype Publications, London.

Collier, J.

1988 Official Identification and Price Guide to Antique and Modern Dolls. 4th edition. Ballentine, New York.

Collins, M. B.

1995 Forty Years of Archaeology in Central Texas. Bulletin of the Texas Archaeological Society 66:361-400. Austin.

Cunnington, C. W., and P. Cunnington

1951 The History of Underclothes. Michael Joseph, London.

de la Teja, J. F.

1995 San Antonio de Béxar: A Community on New Spain's Northern Frontier. University of New Mexico Press, Albuquerque.

Diamond, D. D., D. H. Riskind, and S. L. Orzell

1987 The Texas Journal of Science 39(3):203-221.

Dillehay, T. D.

1974 Late Quaternary Bison Population Changes on the Southern Plains. Plains Anthropologist 19(64):180196.

Durrenberger, E. P.

1965 Anderson's Mill (41TV130): A Historical Site in Travis County, Texas. Bulletin of the Texas Archeological Society 36:1-70.

Dunn, W. E.

1911 Apache Relations in Texas, 1718-1750. Southwestern Historical Quarterly 14:198-274.

Epstein, D.

1968 Buttons. Walker Publishing, New York.

Epstein, D., and M. Safro

1991 Buttons. Harry N. Abrams, Inc., New York.

Foster, W. C.

1995 Spanish Expeditions Into Texas,1689-1768. University of Texas Press, Austin.

Friedel, R.

1983 Pioneer Plastic, The Making and Selling of Celluloid. University of Wisconsin Press, Madison. 
Ford, O. A., and A. S. Lyle

1998 Archaeological Investigation of a Spring Lake Lot for Joe's Crab Shack Parking. Archaeological Survey Report No. 277. Center for Archaeological Research, University of Texas at San Antonio.

Foster, W. C.

1995 Spanish Expeditions into Texas 1689-1768. University of Texas Press, Austin.

Garber, J. F.

1987 Transitional Archaic Structure and Activity Areas at the Zapotec Site, San Marcos, Texas. La Tierra 14(2):19-30.

1992 A Cultural Resources Survey of the Nighthawk Frozen Foods, Inc. Development, Hays County, Texas. Report prepared for John Ater, Hays County Grants Administrator, Hays County Courthouse. San Marcos, Texas.

Garber, J. F., S. Bergman, B. Dickinson, R. W. Hays, III, J. Simpson, and J. Stefanoff

1983 Excavations at Aquarena Springs, San Marcos, Texas. La Tierra 10(2):28-38.

Garber, J. F., and D. M. Glassman

1992 Excavation of Human Remains from the Fish Pond Site, 41 HYl61 in San Marcos, Hays County, Texas. Report prepared for the Texas Antiquities Committee for Permit No. 338. Department of Sociology/ Anthropology, Southwest Texas State University, San Marcos.

Garber, J. F., and M. D. Orloff

1984 Excavations at 41HY37: An Archaic Site on the Balcones Escarpment in San Marcos, Texas. La Tierra 11(3):31-37.

Gilbert, B. M.

1990 Mammalian Osteology. Missouri Archaeological Society, Columbia.

Gilbert, B. M., L. D. Martin, and H. G. Savage

1981 Avian Osteology. B. Miles Gilbert, Publisher, Laramie, Wyoming.

Gilmore, K. K.

1986 French and Indian Interaction at an Eighteenth Century Frontier Post: The Roseborough Site, Bowie City, Texas. Contributions in Archaeology 3. Institute of Applied Sciences, North Texas State University, Denton.

Godwin, M., and W. J. Weaver

1999 A Cultural Resources Survey of an Oasis/TEPPCO Natural Gas Pipeline Lateral Located in the A. M. Esnaurizar Grant in Hays and Guadalupe Counties, Texas. Report prepared for American National Power, Inc., Houston, Texas and submitted to Oasis Pipeline Company Texas L. P., Prairie Lea, Texas by Antiquities Planning and Consulting, Kyle, Texas. Heritage Management Series Survey Report No. 11, June 1999.

Godwin, M. F., F. Weir, J. W. Clark, Jr., W. J. Weaver, S. C. Caran, C. Ringstaff, T. Terneny, D. D. French, and T. Stone

2000 City of San Marcos Spring Lake Water Line Archeological Investigations, Hays County, Texas. Archeological Investigative Report No. 3. Antiquities Planning \& Consulting. Kyle, Texas.

Goelz, M.

1999 Geoarcheological Assessment of the Texas Rivers Center, San Marcos Springs, Hays County, Texas. Technical Report No. 40. Submitted to Texas Parks and Wildlife by Prewitt and Associates, Inc. Cultural Resources Services. Austin. 
Greaser, A., and P. H. Greaser

1967 Homespun Ceramics. 3rd ed. Privately printed. Allentown, Pennsylvania.

Greer, G. H.

1981 American Stonewares, The Art and Craft of Utilitarian Potters. Schiffer Publishing, Exton, England.

Habig, M. A.

1968 The Alamo Chain of Missions, A History of San Antonio's Five Old Missions. Franciscan Herald, Chicago.

Harpur, P. (editor)

1982 The Timetable of Technology: A Record of the 20th Century's Amazing Achievements. Hearst, Washington, D.C.

Harris, E. S.

1985 An Archaeological Study of the Timmeron Rockshelter (41HY95), Hays County, South Central Texas. Southern Texas Archaeological Association Special Publication No. 4. San Antonio, Texas.

Hatcher, M. A.

1932 The Expedition of Don Domingo Terán do los Ríos into Texas. Preliminary Studies of the Texas Catholic Historical Society II(1):1-67.

Hildebrand, $M$.

1955 Skeletal Differences Between Deer, Sheep, and Goats. California Fish and Game 41:327-346.

Hillson, $\mathrm{S}$.

1986 Teeth. Cambridge University Press, Cambridge.

Himmel, K. F.

1999 The Conquest of the Karankawas and the Tonkawas, 1821-1859. Texas A\&M University Press, College Station, Texas.

Hoffman, F. L. (translator)

1935 Diary of the Alarcón Expedition into Texas, 1718-1719 by Fray Francisco Céliz. First published in 1935 by The Quivira Society Publications, Los Angeles. Republished as Quivira Society Publications, Volume V, by Arno Press, New York.

Horrell, C. E.

1999 Drawing Linkages Between Global and Local Processes: Archaeological Investigations of Villa San Marcos de Neve, A Spanish Colonial Town on the Frontier. Unpublished Master's thesis, Department of Anthropology, University of Texas at San Antonio.

Husfloen, K. (editor)

1994 American Pressed Glass and Bottles. Antique Trader Books, Dubuque, Iowa.

Hughes, E., and M. Lester

1991 The Big Book of Buttons. New Leaf, Sedgewick, Maine.

Hume, I. N.

1970 A Guide to the Artifacts of Colonial America. Alfred A. Knopf, New York.

Ing, J. D., and J. Hart

1987 Archeological Investigations at Fanthorp Inn State Historic Site (41GM79) Grime County, Texas, Spring and Fall 1982. Texas Parks and Wildlife Department, Historic Sites and Restoration Branch, Austin, Texas. 
Ivey, J. E., and A. A. Fox

1982 Archaeological Investigations at Mission Concepción and Mission Parkway, Part I: Excavations at Mission Concepción. Archaeological Survey Report No. 114. Center for Archaeological Research, University of Texas at San Antonio.

Jackson, D. (editor and annotator)

1966 The Journals of Zebulon Montgomery Pike with Letters and Related Documents, 2 vols. University of Oklahoma Press, Norman.

Jackson, J.

1986 Los Mesteños: Spanish Ranching in Texas, 1721-1821. Texas A\&M University Press, College Station.

1995 Imaginery Kingdom: Texas as Seen by the Rivera and Rubi Military Expeditions, 1727 and 1767. Texas State Historical Association, Austin.

Jelks, E. B.

1962 The Kyle Site, A Stratified Central Texas Aspect Site in Hill County, Texas. Archaeology Series No. 5. Department of Anthropology. University of Texas, Austin.

Jenkins, J. H., and K. Kesselus

1990 Edward Burleson: Texas Frontier Leader. Jenkins Publishing Company, Austin.

Johnson, D. F.

1948 Uniform Buttons, American Armed Forces, 1784-1948. 2 volumes. Privately published, Watkins Glen, New York.

Johnson, E., and V. T. Holliday

1983 Comments on "Large Springs and Early American Indians" by Joel L. Shiner. Plains Anthropologist 29(103):65-70.

Johnson, L., and T. N. Campbell

1992 Sanan: Traces of a Previously Unknown Aboriginal Language in Colonial Coahuila and Texas. Plains Anthropologist 37(140):185-212.

Jurney, D. H.

1988 Cut and Wire nails: Function and Temporal Interpretations. In Historic Farming on the Hogwallow Prairies: Ethnoarchaeological Investigations of the Mountain Creek Area, North Central Texas, pp. 315-323. Joe Pool Archaeological Project, Volume II, complied by D. H. Jurney, S. A. Lebo, and M. M. Green. Archaeology Research Program, Institute for the Study of Earth and Man, Southern Methodist University, Dallas.

Kovel, R., and T. Kovel

1986 Kovels' New Dictionary of Marks: Pottery and Porcelain 1850 to the Present. Crown Publishers Inc., New York.

2001 Kovels' Antiques \& Collectibles. Three Rivers Press, New York.

Labadie, J. H. (assembler)

1986 La Villita Earthworks (41BX677): San Antonio, Texas. A Preliminary Report of Investigations of Mexican Siege Works at the Battle of the Alamo. Archaeological Survey Report, No. 159. Center for Archaeological Research, University of Texas at San Antonio.

Lamm, R., B. Lorah, L. Lorah, and H. Schuler

1970 Guidelines for Collecting China Buttons. Crown Publishing Company, Boyertown, Pennsylvania. 
Lehner, L.

1988 Lehner's Encyclopedia of American Kitchen and Dinner Wares. Wallace-Homestead, Des Moines, Iowa.

Lord, F. A.

1970 Uniforms of the Civil War. Thomas Yoseloff Ltd., London, England.

Luscomb, S. C.

1967 The Collector's Encyclopedia of Buttons. Crown Publishers, Inc., New York.

Lyman, R. L.

1994 Vertebrate Taphonomy. Cambridge University Press, Cambridge.

Lyle, A. S., C. E. Horrell, S. A. Tomka, and D. Cargill

2000 Archaeological Testing at the Headwaters of the San Marcos River: Southwest Texas State University Raw Water Supply Project. Archaeological Survey Report No. 293. Center for Archaeological Research, University of Texas at San Antonio.

McClintock, W.

1931 Journal of a Trip Through Texas and Northern Mexico in 1846-1847. Southwestern Historical Quarterly (July 1930):20-37.

McGehee, A.

1982 A River Reflects on Pepper's Past: Fact, Lore, Legend about the San Marcos River, the Mill Tract, \& the Old Ice House. Pepper's at the Falls. On file in Special Collections, Alkek Library, Southwest Texas State University, San Marcos, Texas.

Madsen, J.

1985 Mississippi Shell Game. Audubon 87(2):46-69.

Majewski, T., and M. J. O’Brien

1987 The Use and Misuse of Nineteenth-Century English and American Ceramics in Archaeological Analysis. In Advances in Archaeological Method and Theory 11:97-207, edited by M. B. Schiffer. Serial Publication Series, Academic Press, New York.

Meissner, B. A.

1997 Making the Man: Clothing Remains from the Alamodome Project. In Archaeology at the Alamodome: Investigations of a San Antonio Neighborhood in Transition. Vol. III, pp. 119-164, edited by Anne A. Fox, Marcie Renner, and Robert J. Hard. Archaeological Survey Report No. 238, Center for Archaeological Research, University of Texas at San Antonio.

Miller, G. L.

1972 Some Notes on Blue Edgewares. Paper presented at the annual meeting of the Society for Historical Archaeology, Tallahassee, Florida. Copy on file, Center for Archaeological Studies, Southwest Texas State University, San Marcos.

1980 Classification and Economic Scaling of 19th Century Ceramics. Historical Archaeology 14:1-40.

1989 A Chronology of English Shell Edged Pearl and White Wares. Unpublished manuscript, Williamsburg, Pennsylvania.

1991 A Revised Set of CC Index Values for Classification and Economic Scaling of English Ceramics from 1787 to 1880. Historical Archaeology 25(1):1-25.

1993 A User's Guide to Ceramic Assemblages, Part Four: Some Thoughts on Classification of White Earthenwares. Council for Northwest Historical Archaeology Newsletter, No. 26. 
Moir, R. W.

1988 Window Glass. In Historic Farming on the Hogwallow Prairies, Ethnoarchaeological Investigations of the Mountain Creek Area, North Central Texas. Joe Pool Lake Archaeological Project, Vol. 2. Archaeological Research Program, Institute for the Study of Earth and Man, Southern Methodist University, Dallas.

Montgomery Ward and Company

19691895 Montgomery Ward Catalogue. Dover Publications, Inc. New York.

Morris, W. (editor)

1976 The American Heritage Dictionary of the English Language. Houghton Mifflin Company, Boston, Massachusetts.

Munsey, C.

1970 The Illustrated Guide to Collecting Bottles. Hawthorn Books, Inc., New York.

Nelson, L. H.

1968 Nail Chronology as an Aid to Dating Old Buildings. American Association for State and Local History Technical Leaflet 48, History News, Vol. 24, No. 11.

Newcomb, W. W., Jr.

1961 The Indians of Texas From Prehistoric to Modern Times. University of Texas Press, Austin.

1993 Historic Indians of Central Texas. Bulletin of the Texas Archeological Society 64:1-63.

Nickels, D. L.

2000 The Biesenbach Site (41WN88): A Case Study in Diet Breadth. Unpublished Master's thesis. Department of Anthropology, University of Texas at San Antonio.

Nickels, D. L., and R. P. Mauldin

2001 Twin Buttes Archaeological Report. Popular Report Series No. 28. Center for Archaeological Research, University of Texas at San Antonio.

Nickels, D. L., R. Robinson, and C. Murguia

2001 Historic Sites Survey Results and Analysis. In An Archaeological Survey of Twin Buttes Reservoir, Tom Green County, Texas. Vol. I, pp. 155-204, by R. P. Mauldin and D. L. Nickels. Archaeological Survey Report No. 300. Center for Archaeological Research, University of Texas at San Antonio.

Ogden, A. E., R. A. Quick, S. R. Rothermel, and D. L. Lunsford

1986 Hydrogeological and Hydrochemical Investigation of the Edwards Aquifer in the San Marcos Area, Hays County, Texas. Submitted to the U. S. Fish and Wildlife Service, Office of Endangered Species, and the City of San Marcos. Contract No. 14-16-0002-84-228. Copies available at the Edwards Aquifer Research and Data Center, Southwest Texas State University, San Marcos.

Olsen, S. J.

1960 Postcranial Skeletal Characters of Bison and Bos. Peabody Museum, Cambridge.

1964 Mammal Remains from Archaeological Sites Part I: Southeastern and Southwestern United States. Peabody Museum, Cambridge.

1968 Fish, Amphibian, and Reptile Remains from Archaeological Sites Part I: Southeastern and Southwestern United States. Peabody Museum, Cambridge.

Parsons, M., and R. E. Burnett

1984 Landmark Inn State Historic Site: Archeological Investigations, Medina County, Texas 1975-1980. Texas Parks and Wildlife Department, Historic Sites and Restoration Branch, Austin. 
Pierce, Gerald S.

1969 Texas Under Arms, The Camps, Posts, Forts, and Military Towns of the Republic of Texas, 1836-1846, pp. 150-151. Encino Press, Austin.

Pool, J. C.

1987 Appendix V: Fanthorp Inn: A Study of Nineteenth and Twentieth Century Buttons. In Archaeological Excavations at Fanthorp Inn State Historic Site (41GM79) Grimes County, Texas 1982, pp. 277-293. Texas Parks and Wildlife Department, Historic Sites and Restoration Branch, Austin.

Prewitt, E. R.

1974 Archeological Investigations at Loeve-Fox Site, Williams County, Texas. Texas Archeological Survey, Research Report 49. University of Texas at Austin.

1981 Cultural Chronology in Central Texas. Bulletin of the Texas Archaeological Society (52):65-89.

1985 From Circleville to Toyah: Comments on Central Texas Chronology. Bulletin of the Texas Archaeological Society 54:201-238.

Ramsay, J.

1976 American Potters and Pottery. Ars Ceramica, Ann Arbor, Michigan.

Randall, M. E.

1971 Early Marbles. Historical Archaeology 5:102-105.

Ringstaff, C. W.

2000 A Study of Landform Evolution and Archaeological Preservation at Site 41HY165, San Marcos, Texas. Unpublished Master's thesis, Department of Geography, Southwest Texas State University, San Marcos.

Roberson, W. R.

1974 The Carrington-Covert House: Archeological Investigation of a 19th-Century Residence in Austin, Texas. Office of the State Archeologist Reports Number 25. Texas Historical Commission, Austin.

Samford, P. M.

1997 Response to a Market: Dating English Underglaze Transfer-Printed Wares. Historical Archaeology (31)2:1-30.

San Antonio Express [San Antonio]

1915 Photograph of Burleson cabin in ruins. 11 April. San Antonio, Texas.

San Antonio Light [San Antonio]

1911 Photograph illustrating enclosed porch on cabin. 12 March. San Antonio, Texas.

San Marcos Daily Record (SMDR) [San Marcos]

1929 Article concerning opening of hotel built by A. B. Rodgers. 19 April. San Marcos, Texas.

1934 Article mentioning operation of hotel as health resort. 16 February. San Marcos, Texas.

1966 "Historical Survey Group to Have Medallion on Burleson Homestead." 19 May. San Marcos, Texas.

1979 Article concerning operation of the old Burleson school as courthouse and church. 29 April. San Marcos, Texas.

Sauer, S. R.

1998 Fanthorp Inn State Historical Park (41GM79), Grimes County, Texas: Archeological Investigations, 1983-1989. Report of Investigations, Number 116, Prewitt \& Associates, Inc., Austin, Texas.

Schiff, S. O.

1979 Buttons: Art in Manufacture. Miller Publishers, Berkeley, California. 
Schiffer, M. B.

1975 The Effects of Occupation Span on Site Content. The Cache River Project, edited by M. B. Schiffer and J. House, pp. 265-269. Arkansas Archaeological Survey, Fayettville.

Schroeder, E. A. (editor)

1999 Historical and Archeological Investigations Along the Guadalupe-Blanco River Authority's San Marcos Raw Water Pipeline, Hays, Caldwell, Comal, and Guadalupe Counties, Texas. Report prepared for Guadalupe-Blanco River Authority by Paul Price Associates, Inc. PPA Cultural Resources Report Number 236. Austin.

Schroeder, J. J., Jr. (editor)

1971 The Wonderful World of Toys, Games \& Dolls: 1860-1930. DBI, Northfield, Illinois.

Sears, Roebuck and Co.

1993 Sears, Roebuck and Co., The Great Price Maker. Facsimile of the 1902 Edition, Gramercy Books, New York.

Shiner, J. L.

1979 Survey and Testing of the Ice House Site, San Marcos, Hays County, Texas. Report to the Texas Antiquities Commission in Austin, Permit 194. Southern Methodist University, Dallas.

1981 History, Economy, and Magic at a Fresh Water Spring. In The Realms of Gold, Proceedings of the Tenth Conference on Underwater Archaeology. Edited by W. A. Cockrell, pp. 202-203. Fathom Eight, San Marino, California.

1983 Large Springs and Early American Indians. Plains Anthropologist 28(99):1-7.

Sibley, M. M.

1983 Lone Stars and State Gazettes, pp. 187-190, Texas A\&M University Press, College Station.

Sobolik, K. D. and D. G. Steele

1996 A Turtle Atlas to Facilitate Archaeological Identifications. Mammoth Site of Hot Springs, South Dakota, Inc., Rapid City, South Dakota.

Spearing, D.

1991 Roadside Geology of Texas. Mountain Press Publishing Co., Missoula, Montana.

Stovall, F., M. Storm, L. Simon, G. Johnson, D. Schwartz, and D. W. Kerbow

1986 Clear Springs and Limestone Ledges, A History of San Marcos and Hays County for the Texas Sesquicentennial. The Hays County Historical Commission. Nortex Press, Division of Eakin Publications, Austin, Texas.

Swanton, J. R.

1985 Final Report of the United States De Soto Expedition Commission. Smithsonian Institution Press, Washington, D. C.

Takac, P.

1990 "Homebases" and the Paleoindian/Archaic Transition in Central Texas. Paper presented at the 55 ${ }^{\text {th }}$ Annual Society of American Archaeologists Meeting, Las Vegas.

1991a Underwater Excavations at Spring Lake: A Paleoindian Site in Hays County, Texas. Current Research in the Pleistocene 8:46-48.

1991b Paleoindian Occupations at Spring Lake, Hays County, Texas. Dissertation research proposal submitted to the faculty, Department of Anthropology, Southern Methodist University, Dallas. 
Tennis, C.

1996 Archaic Land Use of Upper Leon Creek Terraces: Archaeological Testing in Northern Bexar County, Texas. Archaeological Survey Report No. 234. Center for Archaeological Research, University of Texas at San Antonio.

Texas Republic

1839 An Act to Provide for the Protection of the Northern and Western Frontier. Laws of the Republic of Texas. Fourth Congress 1839-1840.

Texas State Gazette [Austin, Texas]

1849 Advertisement concerning the Burleson mill. 1 December:119. Austin, Texas.

Tosa, $\mathrm{M}$.

1987 Classic Dolls. Abbeville Press, New York.

Toulouse, J. H.

1971 Bottle Makers and Their Marks. Thomas Nelson, Inc., New York.

Tri-Weekly Gazette [Austin, Texas]

1849 Advertisement concerning the Burleson Mill. 3 December:3. Austin, Texas.

Volz, J. R.

1999 IMS-CAP Survey of Aquarena Center for Southwest Texas State University, San Marcos, Texas. Architectural Survey conducted by Volz \& Associates, Inc. Austin, Texas. Report on file at the Center for Archaeological Studies, Southwest Texas State University.

Weddle, R. S.

1964 The San Sabá Mission, Spanish Pivot in Texas. University of Texas Press, Austin.

Weniger, D.

1997 The Explorers' Texas, Volume 2: The Animals They Found. Eakin Press, Austin.

Whittemorre, J.

1992 The Book of Buttons. Dorling Kindersley, Inc., New York.

Wilbarger, J. W.

1985 [1889] Indian Depredations in Texas. 1985 facsimile ed. Eakin Press, Statehouse Press, Austin, Texas.

Wright, G. K.

1997 Excavations and Artifact Distribution Analysis. In Archaeology at the Alamodome: Investigations of a San Antonio Neighborhood in Transition, Vol. II, edited by A. A. Fox, M. Renner, and R. J. Hard. Archaeological Survey Report No. 237. Center for Archaeological Research, University of Texas at San Antonio.

Wyckoff, M. A.

1984 United States Military Buttons of the Land Services 1787-1902: A Guide and Classificatory System. McLean County Historical Society, Bloomington, Illinois.

Zapata, J. E.

1997 Alamodome and Abroad: A Composite Inquiry on Toy Marbles. In Archaeology at the Alamodome: Investigations of a San Antonio Neighborhood in Transition, Vol. III, pp. 100-118, edited by A. A. Fox, M. Renner, and R. J. Hard. Archaeological Survey Report No. 238. Center for Archaeological Research, University of Texas at San Antonio. 
Appendix A

\section{Bottle Glass}

Sorted by Presumed Age, Then by Provenience

David L. Nickels

\begin{tabular}{|c|c|c|c|c|c|c|c|c|c|c|c|c|c|c|c|c|c|c|c|c|}
\hline Unit & Level & $\begin{array}{l}\text { 总 } \\
\text { 志 } \\
\text { 号 }\end{array}$ & 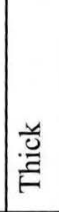 & 目 & 永 & 疋 & 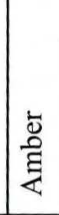 & $\frac{0}{\bar{E}}$ & 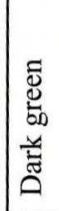 & 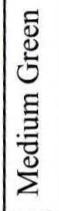 & 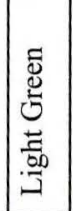 & 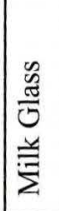 & 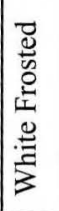 & $\frac{\overrightarrow{\mathbb{E}}}{U}$ & 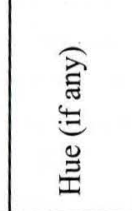 & 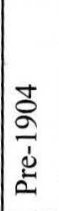 & $\begin{array}{l}\frac{0}{2} \\
\frac{\sigma}{1} \\
\frac{0}{2}\end{array}$ & $\begin{array}{l}0 \\
\frac{2}{2} \\
\frac{1}{\omega} \\
0 \\
2\end{array}$ & Remarks & 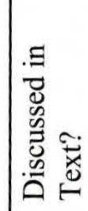 \\
\hline 1 & 1 & 1 & & $\mathrm{x}$ & & & & & & & & & & $\mathrm{x}$ & & & & $\mathrm{x}$ & test tube-like & \\
\hline 1 & 1 & 1 & & $\mathrm{x}$ & & $\mathrm{x}$ & & & & & & & & & & & & $\mathrm{x}$ & modern beer bottle & \\
\hline 1 & 1 & 1 & . & $\mathrm{x}$ & & & & & & $\mathrm{x}$ & & & & & & & & $\mathrm{x}$ & & \\
\hline 1 & 1 & 2 & $\mathrm{x}$ & & & & & & & & $\mathrm{x}$ & & & & & & & $\mathrm{x}$ & & \\
\hline 1 & 1 & 1 & $\mathrm{x}$ & 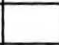 & & & & & & & & & $\mathrm{x}$ & & & & & $\mathrm{x}$ & & \\
\hline 1 & 1 & 1 & & $\mathrm{x}$ & & & & & & & & $\mathrm{x}$ & & & & & & $\mathrm{x}$ & & \\
\hline 1 & 2 & 1 & & $\mathrm{x}$ & & & & & & & & & & $\mathrm{x}$ & & & & $\mathrm{x}$ & modern hand-blown & \\
\hline 1 & 2 & 1 & & $\mathrm{x}$ & & & & & & & & & & $\mathrm{x}$ & 1t. green & & & $\bar{x}$ & melted & \\
\hline 1 & 2 & 1 & $\mathrm{x}$ & & & & & & & & & & $\mathrm{x}$ & & & & & $\mathrm{x}$ & & \\
\hline 2 & 1 & 3 & & $\mathrm{x}$ & & $\mathrm{x}$ & & & & & & & & & & & & $\mathrm{x}$ & modern beer bottle & \\
\hline 2 & 1 & 1 & $\mathrm{x}$ & & & & & & & & & & & & & & & $\mathrm{x}$ & sky blue, melted & \\
\hline 2 & 1 & 12 & & $\mathrm{x}$ & & & & & & & & & & $\mathrm{x}$ & It. green & & & $\mathrm{x}$ & & \\
\hline 2 & 1 & 1 & $\mathrm{x}$ & & & & & & & & $\mathrm{x}$ & & & & & & & $\mathrm{x}$ & Coca Cola bottle & \\
\hline 2 & 1 & 2 & $\mathrm{x}$ & & & & & & & & & $\mathrm{x}$ & & & & & & $\mathrm{x}$ & raised molded design & \\
\hline 2 & 2 & 5 & $\mathrm{x}$ & & + & & & & & & & & & $\mathrm{x}$ & 1t. green & & & $\mathrm{x}$ & & \\
\hline 3 & 1 & 2 & & $\mathrm{x}$ & & & & & & & & & & $\mathrm{x}$ & 1t. green & & & $\mathrm{x}$ & & \\
\hline 3 & 2 & 1 & & $\mathrm{x}$ & & $\mathrm{x}$ & & & & & & & & & & & & $\mathrm{x}$ & modern beer bottle & \\
\hline 5 & 1 & 1 & & $\mathrm{x}$ & & & & & & & & & & $\mathrm{x}$ & & & & $\mathrm{x}$ & & \\
\hline 5 & 1 & 1 & & $\mathrm{x}$ & & & & & & $\mathrm{x}$ & & & & & & & & $\mathrm{x}$ & looks modern & \\
\hline 5 & 1 & 2 & & $\mathrm{x}$ & & $\mathrm{x}$ & & & & & & & & & & & & $\mathrm{x}$ & modern beer bottle & \\
\hline 5 & 1 & 14 & & $\mathrm{x}$ & & & & & & & & & & $\mathrm{x}$ & It. green & & & $\mathrm{x}$ & & \\
\hline 5 & 1 & 1 & $\mathrm{x}$ & & & & & & & & & $\mathrm{x}$ & & & & & & $\mathrm{x}$ & & \\
\hline 6 & 1 & 2 & & $\mathrm{x}$ & & & & & & & & & & $\mathrm{x}$ & & & & $\mathrm{x}$ & test tube-like & \\
\hline 6 & 1 & 1 & & & & $\mathrm{x}$ & & & & & & & & & & & & $\mathrm{x}$ & modern beer bottle & \\
\hline 6 & 1 & 1 & & & $\mathrm{x}$ & & & & & & & & & & & & & $\mathrm{x}$ & blown glass decoration & \\
\hline 6 & 1 & 1 & $\mathrm{x}$ & & & & & & & & & & & $\mathrm{x}$ & 1t. green & & & $\mathrm{x}$ & & \\
\hline
\end{tabular}




\section{Appendix A}

Sorted by Presumed Age, Then by Provenience

Bottle Glass

David L. Nickels

\begin{tabular}{|c|c|c|c|c|c|c|c|c|c|c|c|c|c|c|c|c|c|c|c|c|}
\hline Unit & Level & 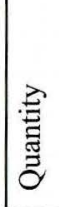 & 弟 & 㼂 & $\frac{\pi}{\frac{\pi}{\alpha}}$ & 药 & 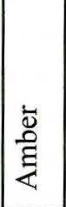 & $\frac{0}{2}$ & 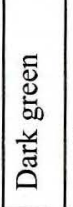 & 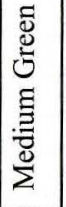 & 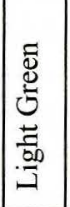 & 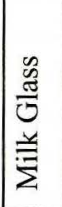 & 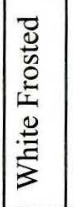 & $\frac{\vec{J}}{U}$ & 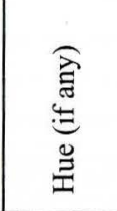 & 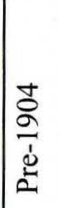 & 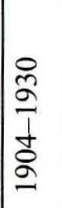 & $\begin{array}{l}0 \\
\frac{0}{2} \\
\frac{1}{\omega} \\
0 \\
2\end{array}$ & Remarks & 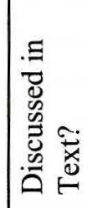 \\
\hline 6 & 2 & 1 & & & & & & & & & & & & $\mathrm{x}$ & & & & $\mathrm{x}$ & lantern globe & \\
\hline 6 & 3 & 1 & . & & & $\mathrm{x}$ & & & & & & & & & & & & $\mathrm{x}$ & modern beer bottle & \\
\hline 7 & 1 & 3 & $\mathrm{x}$ & . & & $\mathrm{x}$ & & & & & & & & & & & & $\mathrm{x}$ & modern beer bottle & \\
\hline 7 & 1 & 1 & & $\mathrm{x}$ & & & & & & & & & & $\mathrm{x}$ & It. green & & & $\mathrm{x}$ & & \\
\hline 7 & 1 & 2 & $\mathrm{x}$ & & & & & & & & & & & & & & & $\mathrm{x}$ & blue & \\
\hline 7 & 1 & 1 & $\mathrm{x}$ & W & & & & & & & & $\mathrm{x}$ & & 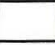 & & & & $\mathrm{x}$ & & \\
\hline 7 & 1 & 4 & & $\mathrm{x}$ & & & & & & & & & $\mathrm{x}$ & & & & & $\mathrm{x}$ & & \\
\hline 8 & 1 & 4 & $x$ & $\mathrm{x}$ & & $\mathrm{x}$ & & & & & & & & 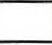 & & & & $\mathrm{x}$ & modern beer bottle & \\
\hline 8 & 1 & 1 & $\mathrm{x}$ & & & & & & & & & & & $\mathrm{x}$ & 1t. green & & & $\mathrm{x}$ & & \\
\hline 8 & 1 & 2 & & $\mathrm{x}$ & & & & & & & & & & $\mathrm{x}$ & It. green & & & $\mathrm{x}$ & & \\
\hline 8 & 2 & 1 & & $\mathrm{x}$ & & & & & & & & & & $\mathrm{x}$ & & & & $\mathrm{x}$ & modern hand-blown & \\
\hline 8 & 2 & 1 & & $\mathrm{x}$ & & & & & & & & & & $\mathrm{x}$ & It. green & & & $\mathrm{x}$ & & \\
\hline 9 & 1 & 1 & & $\mathrm{x}$ & & & & & & & & & & $\mathrm{x}$ & & & & $\mathrm{x}$ & modern hand-blown & \\
\hline 9 & 1 & 1 & & $\mathrm{x}$ & & & & & & $\mathrm{x}$ & & & & & & & & $\mathrm{x}$ & looks modern & \\
\hline 9 & 1 & 4 & $\mathrm{x}$ & & & & & & & & & & $\mathrm{x}$ & & & & & $x$ & & \\
\hline 9 & 2 & 1 & & & & & & & & & & $\mathrm{x}$ & & & & & & $\mathrm{x}$ & & \\
\hline 10 & 1 & 10 & $\mathrm{x}$ & & & $\mathrm{x}$ & & & & & & & & & & & & $\mathrm{x}$ & looks modern & \\
\hline 10 & 1 & 1 & & $\mathrm{x}$ & & & & & & & & & $\mathrm{x}$ & & & & & $\mathrm{x}$ & & \\
\hline 11 & 1 & 1 & $\mathrm{x}$ & & & & & & & & & & & $\mathrm{x}$ & & & & $\mathrm{x}$ & modern blown glass & \\
\hline 11 & 1 & 1 & & $\mathrm{x}$ & & & & & & & & & & & & & & $\mathrm{x}$ & modern w/blue paint & \\
\hline 11 & 1 & 3 & & $\mathrm{x}$ & & & & & & & & & & $\mathrm{x}$ & It. green & & & $\mathrm{x}$ & & \\
\hline 11 & 2 & 1 & & $\mathrm{x}$ & & $\mathrm{x}$ & & & & & & & & & & & & $\mathrm{x}$ & modern beer bottle & \\
\hline 11 & 2 & 4 & & $\mathrm{x}$ & & & & & & & & & & $\mathrm{x}$ & It. green & & & $\mathrm{x}$ & & \\
\hline 12 & 3 & 1 & $\mathrm{x}$ & & & & & & & & & & & $x$ & 1t. green & & & $x$ & & \\
\hline 13 & 1 & 3 & $\mathrm{x}$ & & & & & & & & & & & $\mathrm{x}$ & 1t. green & & & $\mathrm{x}$ & & \\
\hline 13 & 2 & 1 & $\mathrm{x}$ & & & & & & & & & & & $\mathrm{x}$ & & & & $\mathrm{x}$ & cup-mold seam & \\
\hline
\end{tabular}




\section{Appendix A}

\section{Bottle Glass}

Sorted by Presumed Age, Then by Provenience

David L. Nickels

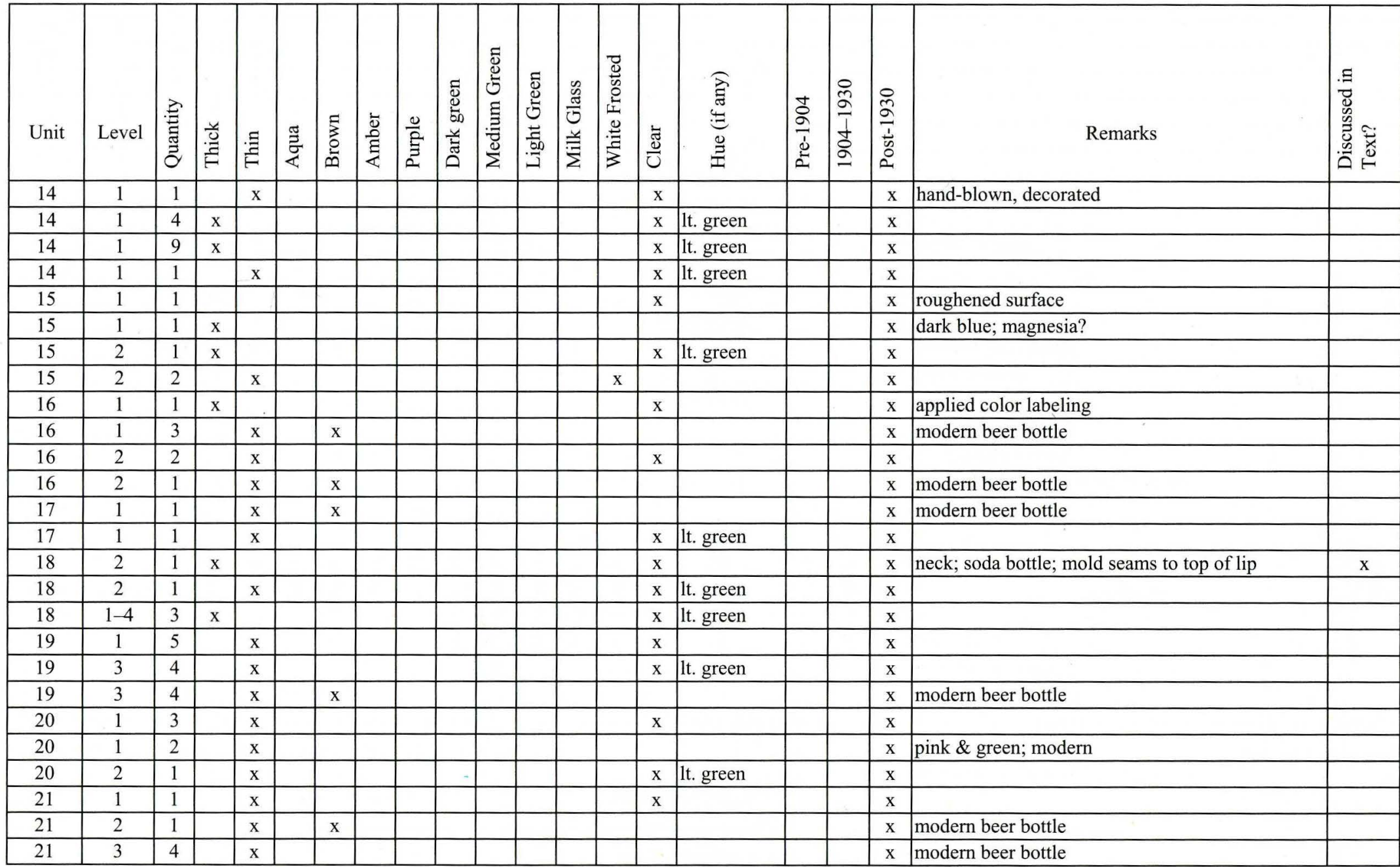




\section{Appendix A}

\section{Bottle Glass}

Sorted by Presumed Age, Then by Provenience

David L. Nickels

\begin{tabular}{|c|c|c|c|c|c|c|c|c|c|c|c|c|c|c|c|c|c|c|c|c|}
\hline Unit & Level & 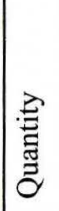 & 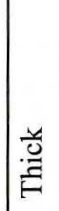 & 軎 & $\frac{\pi}{\tilde{z}}$ & 噶 & $\begin{array}{l}\text { प̆ } \\
\text { 晏 }\end{array}$ & $\frac{0}{\tilde{\Xi}}$ & 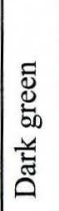 & 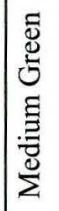 & 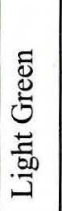 & 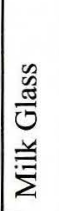 & 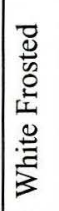 & $\frac{\text { 密 }}{U}$ & 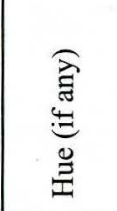 & 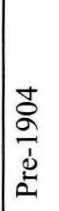 & 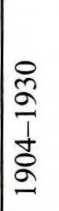 & 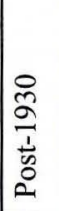 & Remarks & 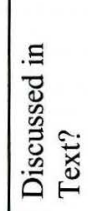 \\
\hline 21 & 3 & 4 & & $\mathrm{x}$ & & & & & & & & & & $\mathrm{x}$ & It. green & & & $\mathrm{x}$ & & \\
\hline 22 & 1 & 1 & & $\mathrm{x}$ & & & & & & & & & & $\mathrm{x}$ & & & & $\mathrm{x}$ & flashbulb & \\
\hline 22 & 1 & 14 & $\mathrm{x}$ & & & & & & & & & & & $\mathrm{x}$ & & & & $\mathrm{x}$ & lip and small neck portion; no hue & \\
\hline 22 & 1 & 7 & & $\mathrm{x}$ & & $\mathrm{x}$ & & & & & & & & & & & & $\mathrm{x}$ & modern beer bottle & \\
\hline 22 & 2 & 2 & & $\mathrm{x}$ & & $\mathrm{x}$ & & & & & & & & 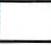 & & & & $\mathrm{x}$ & modern beer bottle & \\
\hline 22 & 3 & 1 & $\mathrm{x}$ & & & & & & & & & & & $\mathrm{x}$ & It. green & & & $\mathrm{x}$ & & \\
\hline 23 & 2 & 2 & $\mathrm{x}$ & & & & & & & & & & & & & & & $\mathrm{x}$ & blue; burned & \\
\hline 23 & 2 & 26 & & $\mathrm{x}$ & & $\mathrm{x}$ & & & & & & & & & & & & $\mathrm{x}$ & modern beer bottle & \\
\hline 23 & 2 & 9 & & $\mathrm{x}$ & & & & & & & & & & $\mathrm{x}$ & 1t. green & & & $\mathrm{x}$ & & \\
\hline 23 & 2 & 3 & $\mathrm{x}$ & & & & & & & & & & & $\mathrm{x}$ & 1t. green & & & $\mathrm{x}$ & & \\
\hline 23 & 2 & 7 & & $\mathrm{x}$ & & & & & & & & & & $\mathrm{x}$ & 1t. green & & & $\mathrm{x}$ & & \\
\hline 23 & 3 & 2 & & $\mathrm{x}$ & & & & & & $\mathrm{x}$ & & & & & & & & $\mathrm{x}$ & looks modern & \\
\hline 23 & 3 & 23 & & $\mathrm{x}$ & & & & & & & & & & $\mathrm{x}$ & 1t. green & & & $\mathrm{x}$ & & \\
\hline 23 & 4 & 6 & & $\mathrm{x}$ & & & & & & & & & & $\mathrm{x}$ & & & & $\mathrm{x}$ & lantern globe & \\
\hline 23 & 4 & 24 & & $\mathrm{x}$ & & & & & & & & & & $\mathrm{x}$ & 1t. green & & & $\mathrm{x}$ & & \\
\hline 23 & 4 & 2 & & $\mathrm{x}$ & & $\mathrm{x}$ & & & & & & & & & & & & $\mathrm{x}$ & & \\
\hline 23 & 4 & 5 & $\mathrm{x}$ & & $\mathrm{x}$ & & & & & & & & & & & & & $\mathrm{x}$ & & \\
\hline 23 & 5 & 8 & & $\mathrm{x}$ & & & & & & & & & & $\mathrm{x}$ & 1t. green & & & $\mathrm{x}$ & & \\
\hline 24 & 1 & 1 & & $\mathrm{x}$ & & & & & & & & & & $\mathrm{x}$ & & & & $\mathrm{x}$ & & \\
\hline 24 & 1 & 3 & $\mathrm{x}$ & & & & & & & & & & $\mathrm{x}$ & & & & & $\mathrm{x}$ & & \\
\hline 24 & 2 & 3 & & $\mathrm{x}$ & & & & & & & & & & $\mathrm{x}$ & 1t. green & & & $\mathrm{x}$ & & \\
\hline 25 & 1 & 1 & & $\mathrm{x}$ & & & & & & & & & & $\mathrm{x}$ & & & & $\mathrm{x}$ & & \\
\hline 25 & 1 & 12 & & $\mathrm{x}$ & & $\mathrm{x}$ & & & & & & & & & & & & $\mathrm{x}$ & modern beer bottle & \\
\hline 25 & 2 & 2 & & $\mathrm{x}$ & & & & & & & & & & $\mathrm{x}$ & & & & $\mathrm{x}$ & & \\
\hline 25 & 2 & 2 & & $\mathrm{x}$ & & & & & & & & & & $\mathrm{x}$ & 1t. green & & & $\mathrm{x}$ & & \\
\hline 25 & 2 & 48 & & $\mathrm{x}$ & & $\mathrm{x}$ & & & & & & & & & & & & $\mathrm{x}$ & modern beer bottle & \\
\hline
\end{tabular}




\section{Appendix A}

\section{Bottle Glass}

Sorted by Presumed Age, Then by Provenience

David L. Nickels

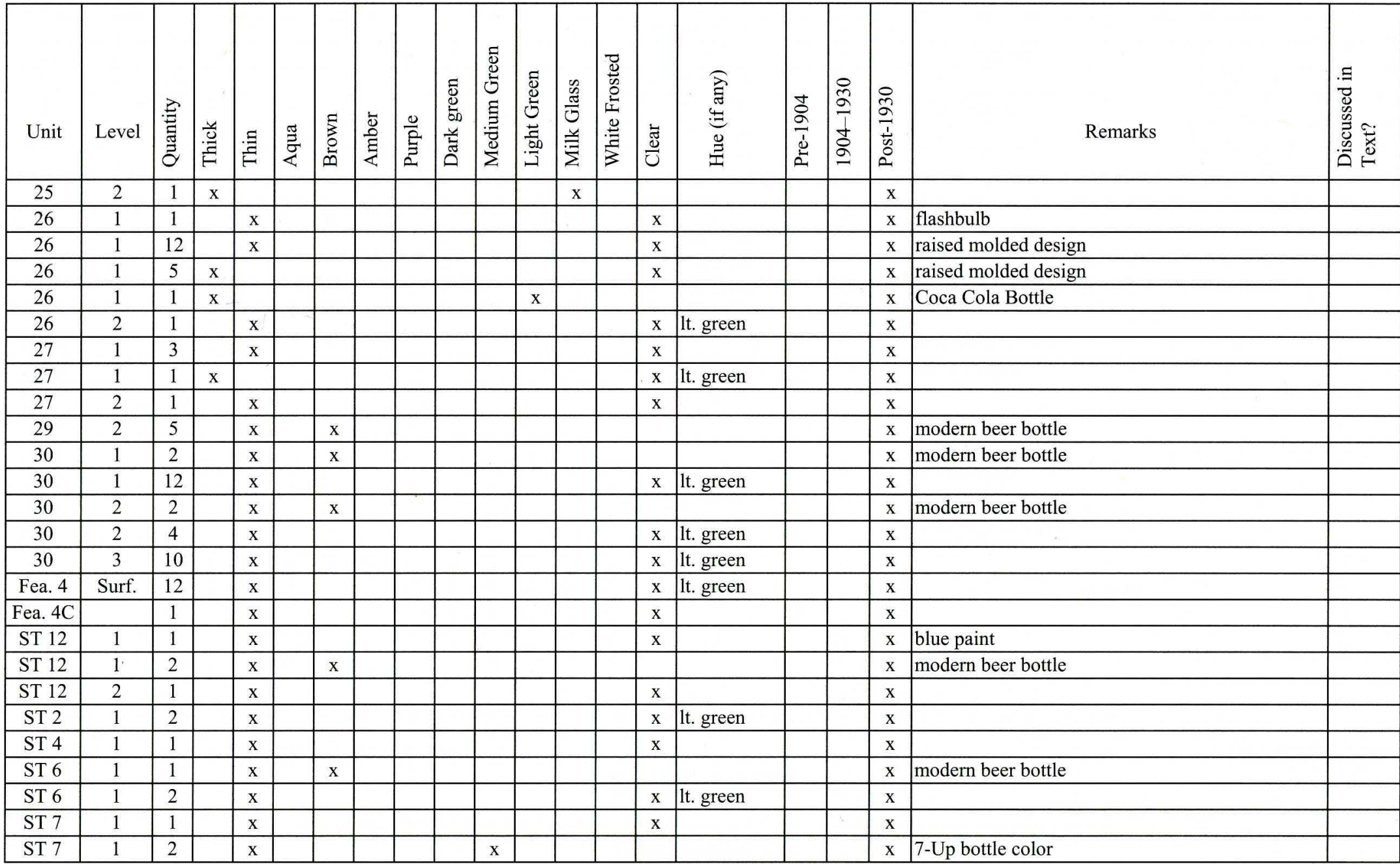




\section{Appendix A}

\section{Bottle Glass}

Sorted by Presumed Age, Then by Provenience

David L. Nickels

\begin{tabular}{|c|c|c|c|c|c|c|c|c|c|c|c|c|c|c|c|c|c|c|c|c|}
\hline Unit & Level & 离 & 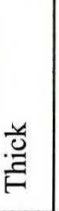 & 寻 & $\frac{\tilde{g}}{\tilde{Z}}$ & 产 & \begin{tabular}{|l} 
\\
D \\
定
\end{tabular} & $\frac{0}{2}$ & 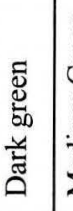 & 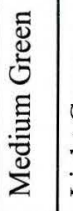 & 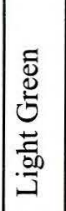 & 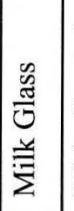 & 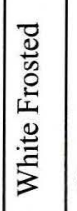 & $\frac{\vec{d}}{0}$ & $\begin{array}{l}\widehat{\widehat{A}} \\
\stackrel{\Xi}{\Xi} \\
\Xi \\
\Xi\end{array}$ & 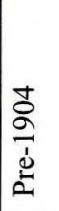 & 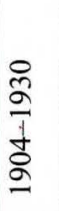 & 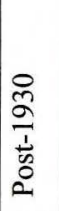 & Remarks & 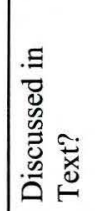 \\
\hline ST 7 & 1 & 4 & & $\mathrm{x}$ & & $\mathrm{x}$ & & & & & & & & & & & & $\mathrm{x}$ & modern beer bottle & \\
\hline ST 8 & 1 & 8 & & $\mathrm{x}$ & & & & & & & & & & $\mathrm{x}$ & 1t. green & & & $\mathrm{x}$ & & \\
\hline Tr-1A & 1 & 1 & & $\mathrm{x}$ & & & & & & & & & & $\mathrm{x}$ & & & & $\mathrm{x}$ & lantern globe & \\
\hline Tr-1A & 1 & 7 & & $\mathrm{x}$ & & $\mathrm{x}$ & & & & & & & & & & & & $\mathrm{x}$ & modern beer bottle & \\
\hline Tr-1A & 1 & 1 & & & & & & $\mathrm{x}$ & & & & & & . & & & & $\mathrm{x}$ & mermaid tail & \\
\hline$\overline{T r-1 A}$ & 2 & 3 & & $\mathrm{x}$ & & & & & & & & & & $\mathrm{x}$ & 1t. green & & & $\mathrm{x}$ & & \\
\hline$\overline{\operatorname{Tr}-1 \mathrm{~B}}$ & 1 & 4 & & & & & & & & & & & & $\mathrm{x}$ & & & & $\mathrm{x}$ & test tube-like & \\
\hline$\overline{\operatorname{Tr}-1 \mathrm{~B}}$ & 1 & 3 & & $\mathrm{x}$ & & $\mathrm{x}$ & & & & & & & & & & & & $\mathrm{x}$ & modern beer bottle & \\
\hline Tr-1B & 1 & 3 & $\mathrm{x}$ & & & & & & & & & & $\mathrm{x}$ & 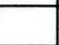 & & & & $\mathrm{x}$ & & \\
\hline 1 & 1 & 27 & $\mathrm{x}$ & & & & & & & & & & & $\mathrm{x}$ & amethyst & & $\mathrm{x}$ & & cup-bottom mold seam & \\
\hline 1 & 1 & 1 & $\mathrm{x}$ & 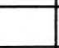 & & & & & & & & & & $\mathrm{x}$ & amethyst & & $\mathrm{x}$ & & machine scars on base & \\
\hline 1 & 1 & 24 & & $\mathrm{x}$ & & & & & & & & & & $\mathrm{x}$ & amethyst & & $\mathrm{x}$ & & & \\
\hline 1 & 1 & 2 & $\mathrm{x}$ & & & & $\mathrm{x}$ & & & & & & & & & & $\mathrm{x}$ & & & \\
\hline 1 & 1 & 2 & & $\mathrm{x}$ & & & & & & & $\mathrm{x}$ & & & & & & $\mathrm{x}$ & & & \\
\hline 1 & 2 & 2 & $\mathrm{x}$ & & & & & & & & & & $\mathrm{x}$ & & amethyst & & $\mathrm{x}$ & & & \\
\hline 1 & 2 & 4 & & $\mathrm{x}$ & & & & & & & & & & $\mathrm{x}$ & amethyst & & $\mathrm{x}$ & & & \\
\hline 2 & 1 & 12 & $\mathrm{x}$ & & & & & & & & & & & $\mathrm{x}$ & amethyst & & $\mathrm{x}$ & & 3 are etched & \\
\hline 2 & 1 & 18 & & $\mathrm{x}$ & & & & & & & & & & $\mathrm{x}$ & amethyst & & $\mathrm{x}$ & & & \\
\hline 2 & 1 & 1 & & $\mathrm{x}$ & & & & & $\mathrm{x}$ & & & & & & & & $\mathrm{x}$ & & heavily patinated & \\
\hline 2 & 2 & 2 & & $\mathrm{x}$ & & & & & & & & & & $\mathrm{x}$ & amethyst & & $\mathrm{x}$ & & & \\
\hline 2 & 2 & 1 & & $\mathrm{x}$ & & & $\mathrm{x}$ & & & & & & & & & & $\mathrm{x}$ & & & \\
\hline 3 & 1 & 1 & & $\mathrm{x}$ & & & & & & & $\mathrm{x}$ & & & & & & $\mathrm{x}$ & & heavily patinated & \\
\hline 5 & 1 & 2 & $\mathrm{x}$ & & & & & & & & & & & $\mathrm{x}$ & amethyst & & $\mathrm{x}$ & & raised molded design & \\
\hline 5 & 1 & 1 & & $\mathrm{x}$ & & & & $\mathrm{x}$ & & & & & & & & & $\mathrm{x}$ & & & \\
\hline 6 & 1 & 1 & $\mathrm{x}$ & & & & & & & & & & & $\mathrm{x}$ & amethyst & & $\mathrm{x}$ & & & \\
\hline 6 & 1 & 4 & & $\mathrm{x}$ & & & & & & & & & & $\mathrm{x}$ & amethyst & & $\mathrm{x}$ & & & \\
\hline
\end{tabular}


Appendix A

Bottle Glass

Sorted by Presumed Age, Then by Provenience

David L. Nickels

\begin{tabular}{|c|c|c|c|c|c|c|c|c|c|c|c|c|c|c|c|c|c|c|c|c|}
\hline Unit & Level & 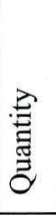 & 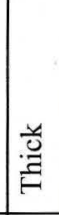 & 灵 & $\frac{\pi}{8}$ & 苟 & $\begin{array}{l}\text { 岕 } \\
\text { 完 }\end{array}$ & $\frac{0}{\underline{\Xi}}$ & 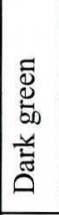 & 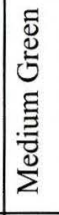 & 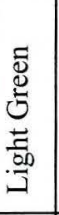 & 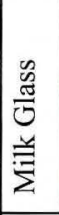 & 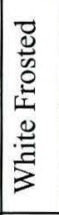 & $\frac{\stackrel{\Phi}{U}}{U}$ & 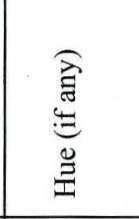 & 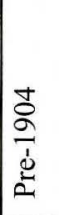 & $\begin{array}{l}\stackrel{\circ}{2} \\
\frac{1}{2} \\
\stackrel{2}{\sigma}\end{array}$ & 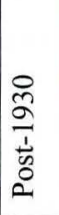 & Remarks & 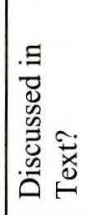 \\
\hline 6 & 2 & 13 & $\mathrm{x}$ & & & & & & & & & & & $\mathrm{x}$ & amethyst & & $\mathrm{x}$ & & & \\
\hline 6 & 2 & 7 & & $\mathrm{x}$ & & & & & & & & & & $\mathrm{x}$ & amethyst & & $\mathrm{x}$ & & & \\
\hline 6 & 2 & 1 & $\mathrm{x}$ & & & & $\mathrm{x}$ & & & & & & & & & & $\mathrm{x}$ & & dark & \\
\hline 6 & 2 & 2 & & $\mathrm{x}$ & & & & & & $\mathrm{x}$ & & & & 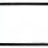 & & & $\mathrm{x}$ & & & \\
\hline 7 & 1 & 2 & $\mathrm{x}$ & & & & & & & & & & & $\mathrm{x}$ & amethyst & & $\mathrm{x}$ & & & \\
\hline 7 & 1 & 3 & $\mathrm{x}$ & & & & & & & & $\mathrm{x}$ & & & & & & $\mathrm{x}$ & & & \\
\hline 8 & 1 & 7 & & $\mathrm{x}$ & & & & & & & & & & $\mathrm{x}$ & amethyst & & $\mathrm{x}$ & & & \\
\hline 8 & 2 & 4 & $\mathrm{x}$ & & & & & & & & & & & $\mathrm{x}$ & amethyst & & $\mathrm{x}$ & & & \\
\hline 8 & 2 & 6 & & $\mathrm{x}$ & & & & & & & & & & $\mathrm{x}$ & amethyst & & $\mathrm{x}$ & & & \\
\hline 8 & 2 & 1 & $\mathrm{x}$ & & & & $\mathrm{x}$ & & & & & & & & & & $\mathrm{x}$ & & heavily patinated & \\
\hline 8 & 2 & 1 & $\mathrm{x}$ & & & & & & & & $\mathrm{x}$ & & & 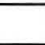 & & & $\mathrm{x}$ & & & \\
\hline 8 & 2 & 5 & & $\mathrm{x}$ & & & & & & $\mathrm{x}$ & & & & 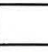 & & & $\mathrm{x}$ & & & \\
\hline 9 & 1 & 5 & & $\mathrm{x}$ & & & & & & & . & & & $\mathrm{x}$ & amethyst & & $\mathrm{x}$ & & & \\
\hline 9 & 1 & 1 & & $\mathrm{x}$ & & & & & & & $\mathrm{x}$ & & & & & & $\mathrm{x}$ & & heavily patinated; aged & \\
\hline 9 & 1 & 1 & $\mathrm{x}$ & & & & & & & & $\mathrm{x}$ & & & & & & $\mathrm{x}$ & & & \\
\hline 9 & 1 & 1 & & $\mathrm{x}$ & & & & & & & $\mathrm{x}$ & & & & & & $\mathrm{x}$ & & & \\
\hline 9 & 2 & 3 & & $\mathrm{x}$ & & & & & & & $\mathrm{x}$ & & & & & & $\mathrm{x}$ & & & \\
\hline 10 & 1 & 1 & 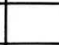 & $\mathrm{x}$ & & & & & & & & & & $\mathrm{x}$ & amethyst & & $\mathrm{x}$ & & & \\
\hline 11 & 1 & 2 & $\mathrm{x}$ & & & & $\mathrm{x}$ & & & & & & & & & & $\mathrm{x}$ & & heavily patinated & \\
\hline 11 & 1 & 1 & $\mathrm{x}$ & & & & & & & & $\mathrm{x}$ & & & & & & $\mathrm{x}$ & & & \\
\hline 11 & 2 & 13 & & $\mathrm{x}$ & & & & $\mathrm{x}$ & & & & & & & & & $\mathrm{x}$ & & raised letters and design & \\
\hline 12 & 1 & 5 & $\mathrm{x}$ & & & & & & & & & & & $\mathrm{x}$ & amethyst & & $\mathrm{x}$ & & raised molded design & \\
\hline 12 & 1 & 1 & & $\mathrm{x}$ & & & & & & & & & & $\mathrm{x}$ & amethyst & & $\mathrm{x}$ & & & \\
\hline 12 & 1 & 3 & & $\mathrm{x}$ & & & $\mathrm{x}$ & & & & & & & & & & $\mathrm{x}$ & & heavily patinated & \\
\hline 12 & 1 & 1 & & $\mathrm{x}$ & & & $\mathrm{x}$ & & & & & & & & & & $\mathrm{x}$ & & heavily patinated & \\
\hline 12 & 3 & 1 & $\mathrm{x}$ & & & & & & & & & & & $\mathrm{x}$ & amethyst & & $\mathrm{x}$ & & & \\
\hline
\end{tabular}


Appendix A

Bottle Glass

Sorted by Presumed Age, Then by Provenience

David L. Nickels

\begin{tabular}{|c|c|c|c|c|c|c|c|c|c|c|c|c|c|c|c|c|c|c|c|}
\hline Unit & Level & 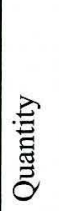 & \begin{tabular}{|l} 
\\
\\
\end{tabular} & 韋 & $\frac{g}{z}$ & 悹 & 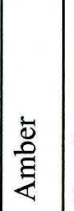 & 曾 & 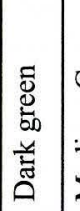 & 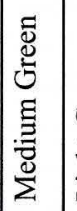 & 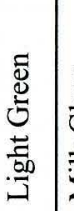 & 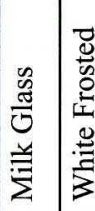 & $\frac{\tilde{J}}{U}$ & 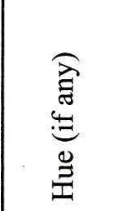 & 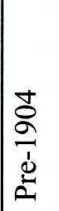 & 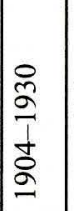 & 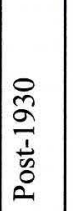 & Remarks & 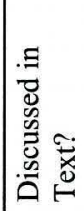 \\
\hline 13 & 1 & 6 & & $\mathrm{x}$ & & & & $\mathrm{x}$ & & & & & & & & $\mathrm{x}$ & & etched; raised letters & $\mathrm{x}$ \\
\hline 13 & 1 & 4 & $\mathrm{x}$ & & & & & & & & & & $\mathrm{x}$ & amethyst & & $\mathrm{x}$ & & & \\
\hline 13 & 1 & 1 & & $\mathrm{x}$ & & & $\mathrm{x}$ & & & & & & & & & $\mathrm{x}$ & & roughened surface & \\
\hline 13 & 2 & 1 & $\mathrm{x}$ & & & & & & & & & & $\mathrm{x}$ & amethyst & & $\mathrm{x}$ & & lipping tool scratches partially obscure mold seam & $\mathrm{x}$ \\
\hline 13 & 2 & 6 & & $\mathrm{x}$ & & & & & & & & & $\mathrm{x}$ & amethyst & & $\mathrm{x}$ & & etched and frosted & $\mathrm{x}$ \\
\hline 13 & 2 & 1 & $\mathrm{x}$ & & & & & & & & & & $\mathrm{x}$ & amethyst & & $\mathrm{x}$ & & & \\
\hline 13 & 2 & 1 & $\mathrm{x}$ & 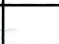 & & & $\mathrm{x}$ & & & & & & & & & $\mathrm{x}$ & & & \\
\hline 13 & 2 & 13 & & $\mathrm{x}$ & & & & & & & & & $\mathrm{x}$ & amethyst & & $\mathrm{x}$ & & & \\
\hline 13 & 2 & 6 & $\mathrm{x}$ & & & & & & & & & & $\mathrm{x}$ & amethyst & & $\mathrm{x}$ & & neck and base & $\mathrm{x}$ \\
\hline 13 & 2 & 4 & $\mathrm{x}$ & & & & & & & & & & $\mathrm{x}$ & amethyst & & $\mathrm{x}$ & & & \\
\hline 13 & 2 & 1 & & $\mathrm{x}$ & & & & & & & $\mathrm{x}$ & & & & & $\mathrm{x}$ & & & \\
\hline 14 & 1 & 1 & & $\mathrm{x}$ & & & & & & $\mathrm{x}$ & & & 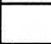 & & & $\mathrm{x}$ & & & \\
\hline 15 & 1 & 2 & $\mathrm{x}$ & & & & & & & & & & $\mathrm{x}$ & amethyst & & $\mathrm{x}$ & & etched and frosted & $\mathrm{x}$ \\
\hline 15 & 1 & 4 & & $\mathrm{x}$ & & & & & & & & & $\mathrm{x}$ & amethyst & & $\mathrm{x}$ & & side mold seam & \\
\hline 15 & 1 & 1 & $\mathrm{x}$ & & & & $\mathrm{x}$ & & & 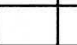 & & & & & & $\mathrm{x}$ & & & \\
\hline 15 & 1 & 2 & $\mathrm{x}$ & & & & & & & $\mathrm{x}$ & & & 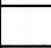 & & & $\mathrm{x}$ & & heavily patinated & \\
\hline 15 & 2 & 2 & $\mathrm{x}$ & & & & & & & & & & $\mathrm{x}$ & amethyst & & $\mathrm{x}$ & & & \\
\hline 15 & 2 & 1 & & $\mathrm{x}$ & & & & & & & & & $\mathrm{x}$ & amethyst & & $\mathrm{x}$ & & & \\
\hline 16 & 1 & 3 & $\mathrm{x}$ & & & & & & & & & & $\mathrm{x}$ & amethyst & & $\mathrm{x}$ & & & \\
\hline 16 & 1 & 2 & $\mathrm{x}$ & & & & & & & & $\mathrm{x}$ & & & & & $\mathrm{x}$ & & & \\
\hline 16 & 2 & 4 & $\mathrm{x}$ & & & & & & & & & & $\mathrm{x}$ & amethyst & & $\mathrm{x}$ & & & \\
\hline 16 & 2 & 1 & $\mathrm{x}$ & & & & & & & & $\mathrm{x}$ & & & & & $\mathrm{x}$ & & & \\
\hline 16 & 2 & 4 & $\mathrm{x}$ & & & & & & & & $\mathrm{x}$ & & & & & $\mathrm{x}$ & & & \\
\hline 16 & 4 & 1 & & $\mathrm{x}$ & & & & & & & $\mathrm{x}$ & & & & & $\mathrm{x}$ & & & \\
\hline 17 & 1 & 1 & & $\mathrm{x}$ & & & & & & & & & $\mathrm{x}$ & amethyst & & $\mathrm{x}$ & & lantern globe & \\
\hline 17 & 1 & 2 & $\mathrm{x}$ & & & & & & & & & & $\mathrm{x}$ & amethyst & & $\mathrm{x}$ & & & \\
\hline
\end{tabular}




\section{Appendix A}

Sorted by Presumed Age, Then by Provenience

\section{Bottle Glass}

David L. Nickels

\begin{tabular}{|c|c|c|c|c|c|c|c|c|c|c|c|c|c|c|c|c|c|c|c|c|}
\hline Unit & Level & 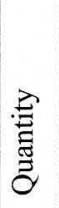 & $\frac{y}{\underline{e}}$ & $\stackrel{\Xi}{\Xi}$ & $\frac{\pi}{\dot{z}}$ & 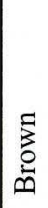 & $\begin{array}{l}\overline{\mathrm{J}} \\
\frac{\mathrm{g}}{\mathrm{Z}}\end{array}$ & $\frac{\ddot{n}}{\vec{z}}$ & 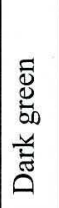 & 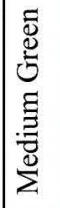 & 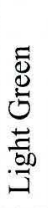 & 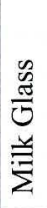 & 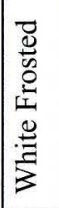 & $\frac{\bar{\Xi}}{\ddot{\circlearrowright}}$ & 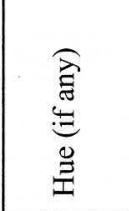 & 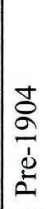 & 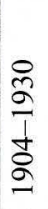 & $\begin{array}{l}0 \\
\stackrel{2}{2} \\
\stackrel{1}{1} \\
\frac{1}{00} \\
0 \\
0\end{array}$ & Remarks & 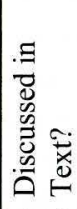 \\
\hline 17 & 1 & 1 & & $\mathrm{x}$ & & & & & & $\mathrm{x}$ & & & & & & & $\mathrm{x}$ & & & \\
\hline 18 & 2 & 1 & $\mathrm{x}$ & & & & & & & & & & & $\mathrm{x}$ & amethyst & & $\mathrm{x}$ & & base, filled with concrete & $\mathrm{x}$ \\
\hline 18 & 2 & 6 & & $\mathrm{x}$ & & & & & & & & & & $\mathrm{x}$ & amethyst & & $\mathrm{x}$ & & raised lettering (refit to sherd in Unit 19 Level 3) & $\mathrm{x}$ \\
\hline 18 & 2 & 2 & & $\mathrm{x}$ & & & & & & & & & & $\mathrm{x}$ & amethyst & & $\mathrm{x}$ & & & \\
\hline 18 & 2 & 1 & $\mathrm{x}$ & & & & $\mathrm{x}$ & & & & & & & & & & $\mathrm{x}$ & & heavily patinated & \\
\hline 18 & $1-4$ & 6 & & $\mathrm{x}$ & & & & & & & & & & $\mathrm{x}$ & amethyst & & $\mathrm{x}$ & & & \\
\hline 19 & 1 & 1 & & $\mathrm{x}$ & & & & & & & $\mathrm{x}$ & & & & & & $\mathrm{x}$ & & & \\
\hline 19 & 1 & 1 & $\mathrm{x}$ & & & & & & & $\mathrm{x}$ & & & & & & & $\mathrm{x}$ & & & \\
\hline 19 & 3 & 13 & & $\mathrm{x}$ & & & & $\mathrm{x}$ & & & & & & & & & $\mathrm{x}$ & & raised lettering; San Marcos drug store (refit) & $\mathrm{x}$ \\
\hline 19 & 3 & 13 & & $\mathrm{x}$ & & & & & & & & & & $\mathrm{x}$ & amethyst & & $\mathrm{x}$ & & & \\
\hline 19 & 3 & 1 & & $\mathrm{x}$ & & & $\mathrm{x}$ & & & & & & & & & & $\mathrm{x}$ & & & \\
\hline 19 & 3 & 2 & & $\mathrm{x}$ & & & & & & $\mathrm{x}$ & & & & & & & $\mathrm{x}$ & & & \\
\hline 19 & 3 & 1 & $\mathrm{x}$ & & & & & & & & $\mathrm{x}$ & & & & & & $\mathrm{x}$ & & & \\
\hline 20 & 1 & 3 & & $\mathrm{x}$ & & & & & & & & & & $\mathrm{x}$ & amethyst & & $\mathrm{x}$ & & & \\
\hline 20 & 1 & 1 & $\mathrm{x}$ & & & & $\mathrm{x}$ & & & & & & & & & & $\mathrm{x}$ & & & \\
\hline 21 & 2 & 2 & $\mathrm{x}$ & & & & & $x$ & & & & & & & & & $\mathrm{x}$ & & goblet base & \\
\hline 21 & 3 & 11 & & $\mathrm{x}$ & & & & & & & & & & $\mathrm{x}$ & amethyst & & $\mathrm{x}$ & & & \\
\hline 21 & 3 & 3 & & $\mathrm{x}$ & & & & & & & $\mathrm{x}$ & & & & & & $\mathrm{x}$ & & & \\
\hline 21 & 4 & 6 & & $\mathrm{x}$ & & & & & & & & & & $\mathrm{x}$ & amethyst & & $\mathrm{x}$ & & & \\
\hline 22 & 1 & 9 & & $\mathrm{x}$ & & & & & & & & & & $\mathrm{x}$ & amethyst & & $\mathrm{x}$ & & 1 lip; 1 neck & \\
\hline 22 & 1 & 1 & $\mathrm{x}$ & & & & $\mathrm{x}$ & & & & & & & & & & $\mathrm{x}$ & & raised molded design & \\
\hline 22 & 1 & 3 & & $\mathrm{x}$ & & & & & & $\mathrm{x}$ & & & & & & & $\mathrm{x}$ & & & \\
\hline 22 & 2 & 1 & $\mathrm{x}$ & & & & & & & & & & & $x$ & amethyst & & $\mathrm{x}$ & & & \\
\hline 22 & 2 & 2 & & $\mathrm{x}$ & & & & & & $\mathrm{x}$ & & & & & & & $\mathrm{x}$ & & & \\
\hline 23 & 2 & 40 & & $\mathrm{x}$ & & & & & & & & & & $\mathrm{x}$ & amethyst & & $\mathrm{x}$ & & raised molded design & \\
\hline 23 & 2 & 12 & & $\mathrm{x}$ & & & & & & & & & & $\mathrm{x}$ & amethyst & & $\mathrm{x}$ & & & \\
\hline
\end{tabular}


Appendix A

\section{Bottle Glass}

Sorted by Presumed Age, Then by Provenience

David L. Nickels

\begin{tabular}{|c|c|c|c|c|c|c|c|c|c|c|c|c|c|c|c|c|c|c|c|c|}
\hline Unit & Level & 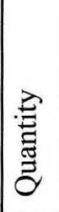 & 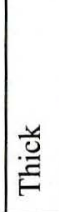 & 当 & $\frac{\tilde{g}}{\mathbb{Z}}$ & 点 & \begin{tabular}{|l} 
岕 \\
塄
\end{tabular} & $\frac{0}{2}$ & 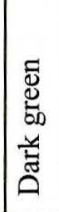 & 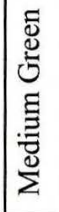 & 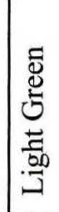 & 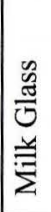 & 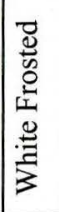 & $\begin{array}{l}\frac{\vec{\varpi}}{U} \\
\end{array}$ & 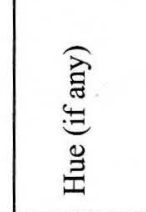 & 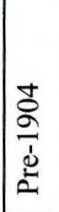 & 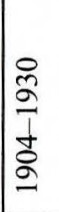 & 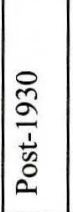 & Remarks & 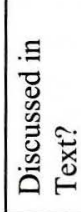 \\
\hline 23 & 3 & 8 & & $\mathrm{x}$ & & & & & & & & & & $\mathrm{x}$ & amethyst & & $\mathrm{x}$ & & & \\
\hline 23 & 3 & 2 & $\mathrm{x}$ & & & $\mathrm{x}$ & & & & & & & & & & & $\mathrm{x}$ & & raised lettering & \\
\hline 23 & 3 & 2 & & $\mathrm{x}$ & & & & & & & $\mathrm{x}$ & & & & & & $\mathrm{x}$ & & & \\
\hline 23 & 4 & 9 & $\mathrm{x}$ & & & & & & & & & & & $\mathrm{x}$ & amethyst & & $\mathrm{x}$ & & stopper neck & \\
\hline 23 & 4 & 2 & $\mathrm{x}$ & ( & & & $\mathrm{x}$ & & & & & & & & & & $\mathrm{x}$ & & & \\
\hline 23 & 4 & 3 & & $\mathrm{x}$ & & $\mathrm{x}$ & & & & & & & & 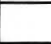 & & & $\mathrm{x}$ & & raised lettering & \\
\hline 23 & 5 & 6 & & $\mathrm{x}$ & & & & & & & & & & $\mathrm{x}$ & amethyst & & $\mathrm{x}$ & & & \\
\hline 23 & 5 & 2 & $\mathrm{x}$ & & & & $\mathrm{x}$ & & & & & & & & & & $\mathrm{x}$ & & heavily patinated & \\
\hline 23 & 5 & 1 & & $\mathrm{x}$ & & & $\mathrm{x}$ & & & & & & & & & & $\mathrm{x}$ & & heavily patinated & \\
\hline 24 & 1 & 21 & & $\mathrm{x}$ & & & & & & & & & & $\mathrm{x}$ & amethyst & & $\mathrm{x}$ & & raised lettering & \\
\hline 24 & 1 & 2 & $\mathrm{x}$ & & & & & & & & & & & $\mathrm{x}$ & amethyst & & $\mathrm{x}$ & & & \\
\hline 24 & 1 & 14 & & $\mathrm{x}$ & & & & & & & & & & $\mathrm{x}$ & amethyst & & $\mathrm{x}$ & & & \\
\hline 24 & 1 & 1 & $\mathrm{x}$ & & & & $\mathrm{x}$ & & & & & & & & & & $\mathrm{x}$ & & & \\
\hline 24 & 1 & 3 & & $\mathrm{x}$ & & & & & $\mathrm{x}$ & & & & & & & & $\mathrm{x}$ & & & \\
\hline 26 & 1 & 2 & & $\mathrm{x}$ & & & $\mathrm{x}$ & & & & & & & & & & $\mathrm{x}$ & & neck fragment & \\
\hline 26 & 1 & 3 & & $\mathrm{x}$ & & & & & & $\mathrm{x}$ & & & & & & & $\mathrm{x}$ & & fragmented base; post-mold seam; embossed & \\
\hline 26 & 2 & 5 & $\mathrm{x}$ & & & & & $\mathrm{x}$ & & & & & & & & & $\mathrm{x}$ & & goblet base & \\
\hline 26 & 2 & 1 & & $\mathrm{x}$ & & & & & & & & & & $\mathrm{x}$ & amethyst & & $\mathrm{x}$ & & & \\
\hline 26 & 2 & 1 & $\mathrm{x}$ & & & & & & & $\mathrm{x}$ & & & & & & & $\mathrm{x}$ & & & \\
\hline 26 & 3 & 8 & & $\mathrm{x}$ & & & & & & & & & & $\mathrm{x}$ & amethyst & & $\mathrm{x}$ & & & \\
\hline 26 & 3 & 1 & $\mathrm{x}$ & & & & $\mathrm{x}$ & & & & & & & & & & $\mathrm{x}$ & & heavily patinated & \\
\hline 26 & 3 & 1 & & $\mathrm{x}$ & & & & & & & $\mathrm{x}$ & & & & & & $\mathrm{x}$ & & & \\
\hline 27 & 1 & 2 & & $\mathrm{x}$ & & & & & & & & & & $\mathrm{x}$ & amethyst & & $\mathrm{x}$ & & & \\
\hline 27 & 1 & 1 & & $\mathrm{x}$ & & & & & & $\mathrm{x}$ & & & & & & & $\mathrm{x}$ & & (2: & \\
\hline 28 & 1 & 1 & $\mathrm{x}$ & & & & & & & & & & & $\mathrm{x}$ & amethyst & & $\mathrm{x}$ & & stopper neck; machine mold scars & $\mathrm{x}$ \\
\hline 28 & 1 & 3 & & $\mathrm{x}$ & & & & & & & & & & $\mathrm{x}$ & amethyst & & $\mathrm{x}$ & & raised molded design & \\
\hline
\end{tabular}




\section{Appendix A}

\section{Bottle Glass}

Sorted by Presumed Age, Then by Provenience

David L. Nickels

\begin{tabular}{|c|c|c|c|c|c|c|c|c|c|c|c|c|c|c|c|c|c|c|c|c|}
\hline Unit & Level & 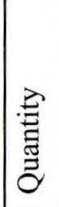 & 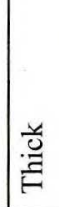 & 蚝 & 氶 & 疍 & $\begin{array}{l}\text { 峁 } \\
\text { है }\end{array}$ & $\frac{0}{\frac{0}{2}}$ & 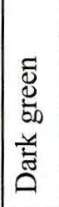 & 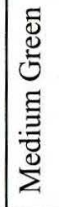 & 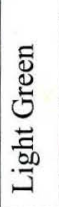 & 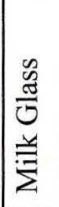 & 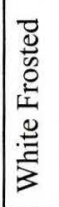 & 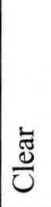 & 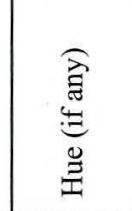 & 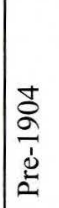 & 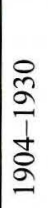 & 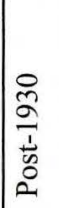 & Remarks & 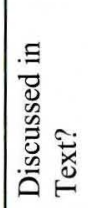 \\
\hline 28 & 1 & 4 & $\mathrm{x}$ & & & & & & & & & & & $\mathrm{x}$ & amethyst & & $\mathrm{x}$ & & & \\
\hline 29 & 2 & 13 & & $\mathrm{x}$ & & & & & & & & & & $\mathrm{x}$ & amethyst & & $\mathrm{x}$ & & & \\
\hline 30 & 1 & 8 & & $\mathrm{x}$ & & & & & & & & & & $\mathrm{x}$ & amethyst & & $\mathrm{x}$ & & & \\
\hline 30 & 1 & 3 & $\mathrm{x}$ & & & & $\mathrm{x}$ & & & & & & & & & & $\mathrm{x}$ & & heavily patinated & \\
\hline 30 & 2 & 33 & & $\mathrm{x}$ & & & & & & & & & & $\mathrm{x}$ & amethyst & & $\mathrm{x}$ & & & \\
\hline 30 & 2 & 4 & $\mathrm{x}$ & & & & $\mathrm{x}$ & & & & & & & & & & $\mathrm{x}$ & & heavily patinated & \\
\hline 30 & 2 & 4 & $\mathrm{x}$ & & & & & & & & $\mathrm{x}$ & & & . & & & $\mathrm{x}$ & & heavily patinated & \\
\hline 30 & 3 & 9 & & $\mathrm{x}$ & & & & & & & & & & $\mathrm{x}$ & amethyst & & $\mathrm{x}$ & & & \\
\hline 30 & 3 & 2 & $\mathrm{x}$ & & & & $\mathrm{x}$ & & & & & & & & & & $\mathrm{x}$ & & heavily patinated & \\
\hline 30 & 3 & 3 & & $\mathrm{x}$ & & & & & & & $\mathrm{x}$ & & & 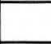 & & & $\mathrm{x}$ & & & \\
\hline- & Sndbx & 2 & $\mathrm{x}$ & & & & & & & & & & & $\mathrm{x}$ & amethyst & & $\mathrm{x}$ & & 'patented' mark; raised molded letters & $\mathrm{x}$ \\
\hline- & Sndbx & 3 & $\mathrm{x}$ & . & & & & & & & $\mathrm{x}$ & & & & & & $\mathrm{x}$ & & bottling works of San Marcos & $\mathrm{x}$ \\
\hline Fea. $4 \mathrm{~K}$ & & 1 & & $\mathrm{x}$ & & & & & & & $\mathrm{x}$ & & & & & & $\mathrm{x}$ & & & \\
\hline ST 12 & 2 & 2 & $\mathrm{x}$ & & & & & & & & $\mathrm{x}$ & & & & & & $\mathrm{x}$ & & raised molded design & \\
\hline ST 3 & 1 & 1 & $\mathrm{x}$ & & & & & & & & $\mathrm{x}$ & & & & & & $\mathrm{x}$ & & & \\
\hline ST 4 & 1 & 1 & & $\mathrm{x}$ & & & & & & & $\mathrm{x}$ & & & & & & $\mathrm{x}$ & & & \\
\hline ST 6 & 1 & 1 & & $\mathrm{x}$ & & & & & & & $\mathrm{x}$ & & & & & & $\mathrm{x}$ & & & \\
\hline ST 6 & 2 & 5 & & $\mathrm{x}$ & & & & & & & & & & $\mathrm{x}$ & amethyst & & $\mathrm{x}$ & & & \\
\hline ST 7 & 1 & 1 & $\mathrm{x}$ & & & & $\mathrm{x}$ & & & & & & & & & & $\mathrm{x}$ & & & \\
\hline ST 7 & 1 & 1 & & $\mathrm{x}$ & & & & $\mathrm{x}$ & & & & & & & & & $\mathrm{x}$ & & & \\
\hline ST 8 & 1 & 1 & $\mathrm{x}$ & & & & & & & & & & & $\mathrm{x}$ & amethyst & & $\mathrm{x}$ & & & \\
\hline ST 8 & 1 & 1 & $\mathrm{x}$ & & & & $\mathrm{x}$ & & & & & & & & & & $\mathrm{x}$ & & heavily encrusted & \\
\hline $\operatorname{Tr}-1 \mathrm{~A}$ & 1 & 4 & $\mathrm{x}$ & & & & & & & & & & & $\mathrm{x}$ & amethyst & & $\mathrm{x}$ & & cup-bottom mold seam & \\
\hline Tr-1A & 1 & 6 & & $\mathrm{x}$ & & & & & & & & & & $\mathrm{x}$ & amethyst & & $\mathrm{x}$ & & & \\
\hline Tr-1A & 1 & 4 & & $\mathrm{x}$ & & & & & & & & & & $\mathrm{x}$ & amethyst & & $\mathrm{x}$ & & & \\
\hline Tr-1A & 1 & 1 & $\mathrm{x}$ & & & & $\mathrm{x}$ & & & & & & & & & & $\mathrm{x}$ & & & \\
\hline
\end{tabular}


Appendix A

\section{Bottle Glass}

Sorted by Presumed Age, Then by Provenience

David L. Nickels

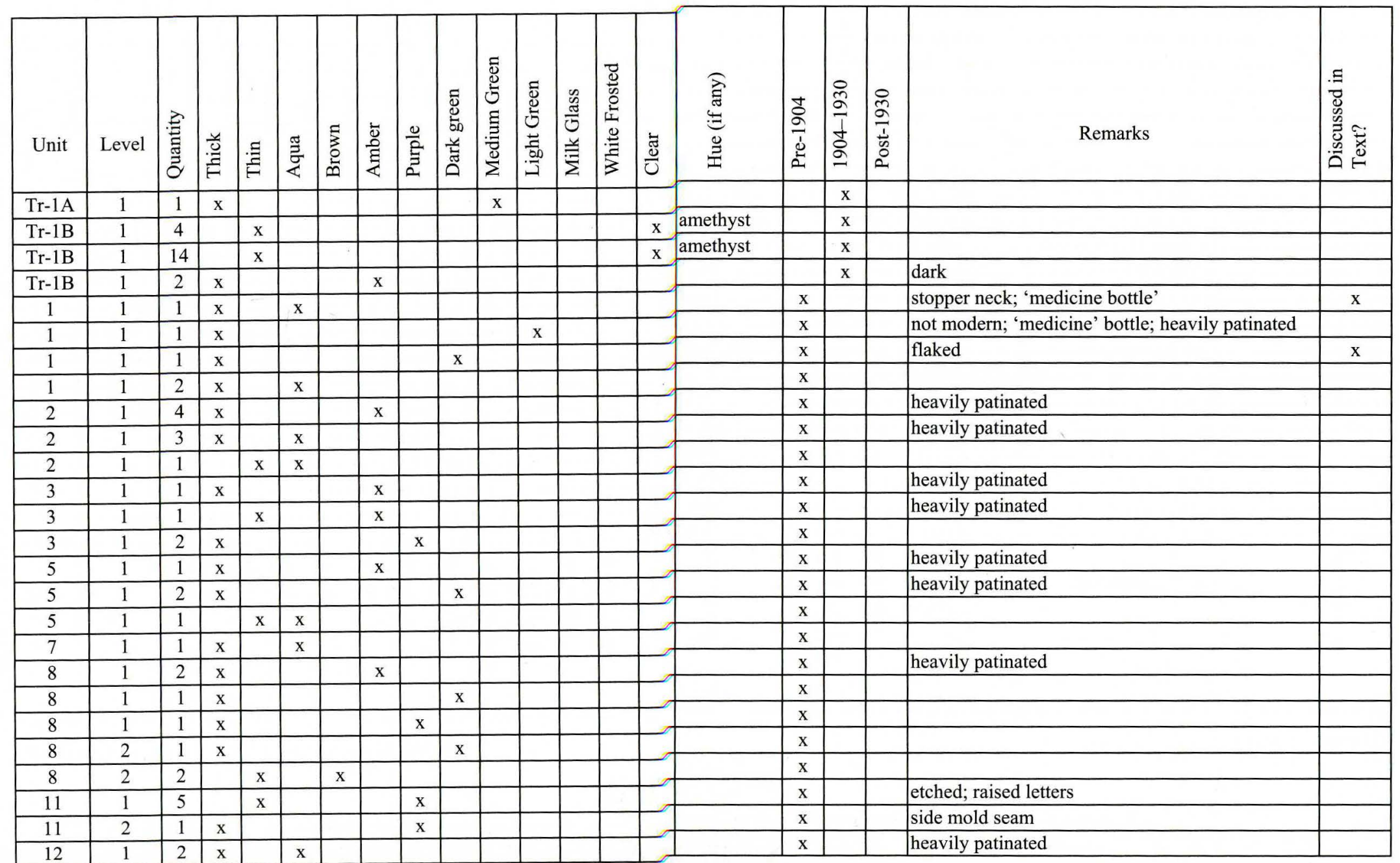




\section{Appendix A}

\section{Bottle Glass}

Sorted by Presumed Age, Then by Provenience

David L. Nickels

\begin{tabular}{|c|c|c|c|c|c|c|c|c|c|c|c|c|c|c|c|c|c|c|c|c|}
\hline Unit & Level & 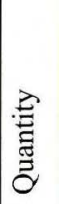 & 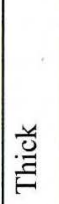 & 当 & 爱 & 䞤 & $\begin{array}{l}\text { 岕 } \\
\text { 甚 }\end{array}$ & $\frac{0}{\mathrm{~g}}$ & 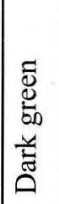 & 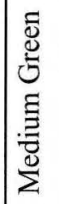 & 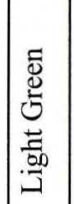 & 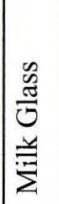 & 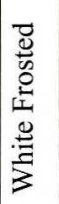 & $\frac{\stackrel{E}{J}}{U}$ & 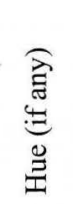 & 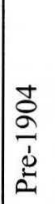 & 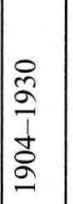 & 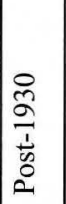 & Remarks & 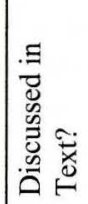 \\
\hline 12 & 1 & 3 & & $\mathrm{x}$ & $\mathrm{x}$ & & & & & & & & & & & $\mathrm{x}$ & & & heavily patinated & \\
\hline 12 & 1 & 1 & $\mathrm{x}$ & & & & & & $\mathrm{x}$ & & & & & & & $\mathrm{x}$ & & & heavily patinated & \\
\hline 12 & 1 & 2 & $\mathrm{x}$ & & & & & $\mathrm{x}$ & & & & & & & & $\mathrm{x}$ & & & side mold seam & \\
\hline 12 & 2 & 6 & $\mathrm{x}$ & & & & & & & & $\mathrm{x}$ & & & & & $\mathrm{x}$ & & & raised lettering; rectangular; 'medicine' bottle & $\mathrm{x}$ \\
\hline 12 & 2 & 2 & $\mathrm{x}$ & & & & & $\mathrm{x}$ & & & & & & & & $\mathrm{x}$ & & & & \\
\hline 12 & 3 & 1 & $\mathrm{x}$ & & $\mathrm{x}$ & & & & & & & & & & & $\mathrm{x}$ & & & heavily encrusted & \\
\hline 13 & 1 & 3 & $\mathrm{x}$ & & & & & & $\mathrm{x}$ & & & & & & & $\mathrm{x}$ & & & & \\
\hline 13 & 1 & 5 & $\mathrm{x}$ & & & & & $\mathrm{x}$ & & & & & & & & $\mathrm{x}$ & & & & \\
\hline 13 & 2 & 3 & & $\mathrm{x}$ & $\mathrm{x}$ & & & & & & & & & & & $\mathrm{x}$ & & & heavily patinated & \\
\hline 13 & 2 & 5 & $\mathrm{x}$ & & $\mathrm{x}$ & & & . & & & & & & & & $\mathrm{x}$ & & & & \\
\hline 13 & 3 & 1 & & $\mathrm{x}$ & & & & $\mathrm{x}$ & & & & & & & & $\mathrm{x}$ & & & & \\
\hline 14 & 1 & 2 & & $\mathrm{x}$ & & & & & $\mathrm{x}$ & & & & & & & $\mathrm{x}$ & & & heavily patinated & \\
\hline 14 & 1 & 3 & $\mathrm{x}$ & & & & & & $\mathrm{x}$ & & & & & & & $\mathrm{x}$ & & & heavily encrusted & \\
\hline 14 & 1 & 3 & & $\mathrm{x}$ & & & & & & & $\mathrm{x}$ & & & & & $\mathrm{x}$ & & & heavily encrusted & \\
\hline 14 & 1 & 1 & $\mathrm{x}$ & & $\mathrm{x}$ & & & 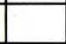 & & & & & & & & $\mathrm{x}$ & & & & \\
\hline 14 & 1 & 2 & $\mathrm{x}$ & & & & & $\mathrm{x}$ & & & & & & & & $\mathrm{x}$ & & & & \\
\hline 14 & 1 & 3 & & $\mathrm{x}$ & $\mathrm{x}$ & & & & & & & & & & & $\mathrm{x}$ & & & & \\
\hline 14 & 1 & 5 & - & $\mathrm{x}$ & & & & $\mathrm{x}$ & & & & & & & & $\mathrm{x}$ & & & & \\
\hline 15 & 1 & 1 & $\mathrm{x}$ & & & & & & $\mathrm{x}$ & & & & & & & $\mathrm{x}$ & & & & \\
\hline 15 & 1 & 7 & $\mathrm{x}$ & & $\mathrm{x}$ & & & & & & & & & & & $\mathrm{x}$ & & & & \\
\hline 15 & 1 & 3 & $\mathrm{x}$ & & $\mathrm{x}$ & & & & & & & & & & & $\mathrm{x}$ & & & & \\
\hline 15 & 2 & 1 & $\mathrm{x}$ & & $\mathrm{x}$ & & & & & & & & & & & $\mathrm{x}$ & & & heavily patinated & \\
\hline 17 & 1 & 1 & & $\mathrm{x}$ & & & & & $\mathrm{x}$ & & & & & & & $\mathrm{x}$ & & & & \\
\hline 18 & $1-4$ & 1 & $\mathrm{x}$ & & & & & $\mathrm{x}$ & & & & & & & & $\mathrm{x}$ & & & & \\
\hline 20 & 1 & 1 & $\mathrm{x}$ & & & $\mathrm{x}$ & & & & & & & & & & $\mathrm{x}$ & & & base; post-bottom mold seam; no pontil scar & $\mathrm{x}$ \\
\hline 20 & 1 & 2 & $\mathrm{x}$ & & & & & & $\mathrm{x}$ & & & & & & & $\mathrm{x}$ & & & applied lip w/distinct point of contact; tooled lip & $\mathrm{x}$ \\
\hline
\end{tabular}




\section{Appendix A}

Sorted by Presumed Age, Then by Provenience

\section{Bottle Glass}

David L. Nickels

\begin{tabular}{|c|c|c|c|c|c|c|c|c|c|c|c|c|c|c|c|c|c|c|c|c|}
\hline Unit & Level & $\begin{array}{l}\stackrel{\vec{E}}{\vec{E}} \\
\text { 急 }\end{array}$ & 曾 & 車 & $\frac{\sigma}{\frac{\sigma}{2}}$ & 㿣 & 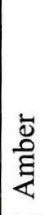 & 号 & 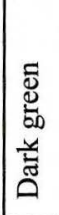 & 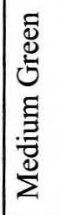 & 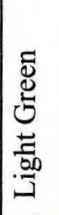 & 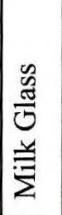 & 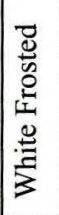 & 苞 & 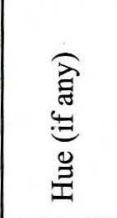 & 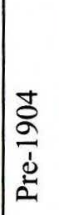 & $\begin{array}{l}0 \\
\text { a } \\
\text { ț } \\
\text { a }\end{array}$ & $\begin{array}{l}0 \\
\frac{\tilde{2}}{2} \\
\frac{1}{\dot{1}} \\
0 \\
2\end{array}$ & Remarks & 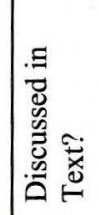 \\
\hline 1 & 1 & 1 & & $\mathrm{x}$ & & & & & & & & & & $\mathrm{x}$ & & & & $\mathrm{x}$ & test tube-like & \\
\hline 1 & 1 & 1 & & $\mathrm{x}$ & & $\mathrm{x}$ & & & & & & & & & & & & $\mathrm{x}$ & modern beer bottle & \\
\hline 1 & 1 & 1 & & $\mathrm{x}$ & & & & & & $\mathrm{x}$ & & & & & & & & $\mathrm{x}$ & & \\
\hline 1 & 1 & 2 & $\mathrm{x}$ & & & & & & & & $\mathrm{x}$ & & & & & & & $\mathrm{x}$ & & \\
\hline 1 & 1 & 1 & $\mathrm{x}$ & 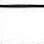 & & & & & & & & & $\mathrm{x}$ & & & & & $\mathrm{x}$ & & \\
\hline 1 & 1 & 1 & & $\mathrm{x}$ & & & & & & & & $\mathrm{x}$ & & & & & & $\mathrm{x}$ & & \\
\hline 1 & 2 & 1 & & $\mathrm{x}$ & & & & & & & & & & $\mathrm{x}$ & & & & $\mathrm{x}$ & modern hand-blown & \\
\hline 1 & 2 & 1 & & $\mathrm{x}$ & & & & & & & & & & $\mathrm{x}$ & It. green & & & $\mathrm{x}$ & melted & \\
\hline 1 & 2 & 1 & $\mathrm{x}$ & & & & & & & & & & $\mathrm{x}$ & & & & & $\mathrm{x}$ & & \\
\hline 2 & 1 & 3 & & $\mathrm{x}$ & & $\mathrm{x}$ & & & & & & & & & & & & $\mathrm{x}$ & modern beer bottle & \\
\hline 2 & 1 & 1 & $\mathrm{x}$ & & & & & & & & & & & & & & & $\mathrm{x}$ & sky blue, melted & \\
\hline 2 & 1 & 12 & & $\mathrm{x}$ & & & & & & & & & & $\mathrm{x}$ & 1t. green & & & $\mathrm{x}$ & & \\
\hline 2 & 1 & 1 & $\mathrm{x}$ & & & & & & & & $\mathrm{x}$ & & & & & & & $\mathrm{x}$ & Coca Cola bottle & \\
\hline 2 & 1 & 2 & $\mathrm{x}$ & & & & & & & & & $\mathrm{x}$ & & . & & & & $\mathrm{x}$ & raised molded design & \\
\hline 2 & 2 & 5 & $\mathrm{x}$ & 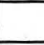 & & & & & & & & & & $\mathrm{x}$ & 1t. green & & & $\mathrm{x}$ & & \\
\hline 3 & 1 & 2 & & $\mathrm{x}$ & & & & & & & & & & $\mathrm{x}$ & It. green & & & $\mathrm{x}$ & & \\
\hline 3 & 2 & 1 & & $\mathrm{x}$ & & $\mathrm{x}$ & & & & & & & & & & & & $\mathrm{x}$ & modern beer bottle & \\
\hline 5 & 1 & 1 & & $\mathrm{x}$ & & & & & & & & & & $\mathrm{x}$ & & & & $\mathrm{x}$ & & \\
\hline 5 & 1 & 1 & & $\mathrm{x}$ & & & & & & $\mathrm{x}$ & & & & & & & & $\mathrm{x}$ & looks modern & \\
\hline 5 & 1 & 2 & & $\mathrm{x}$ & & $\mathrm{x}$ & & & & & & & & & & & & $\mathrm{x}$ & modern beer bottle & \\
\hline 5 & 1 & 14 & & $\mathrm{x}$ & & & & & & & & & & $\mathrm{x}$ & 1t. green & & & $\mathrm{x}$ & & \\
\hline 5 & 1 & 1 & $\mathrm{x}$ & & & & & & & & & $\mathrm{x}$ & & & & & & $\mathrm{x}$ & & \\
\hline 6 & 1 & 2 & & $\mathrm{x}$ & & & & & & & & & & $\mathrm{x}$ & & & & $\mathrm{x}$ & test tube-like & \\
\hline 6 & 1 & 1 & & & & $\mathrm{x}$ & & & & & & & & & & & & $\mathrm{x}$ & modern beer bottle & \\
\hline 6 & 1 & 1 & & & $\mathrm{x}$ & & & & & & & & & & & & & $\mathrm{x}$ & blown glass decoration & \\
\hline 6 & 1 & 1 & $\mathrm{x}$ & & & & & & & & & & & $\mathrm{x}$ & 1t. green & & & $\mathrm{x}$ & & \\
\hline
\end{tabular}




\section{A prendix A}

\section{Bottle Glass}

Sorted by Presumed Age, Then by Provenience

David L. Nickels

\begin{tabular}{|c|c|c|c|c|c|c|c|c|c|c|c|c|c|c|c|c|c|c|c|c|}
\hline Unit & Level & $\begin{array}{l}\stackrel{\nexists}{\vec{E}} \\
\text { 言 } \\
\vec{\partial}\end{array}$ & 晜 & 寻 & $\frac{\pi}{4}$ & 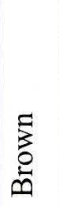 & $\begin{array}{l}\text { 岕 } \\
\text { 夏 }\end{array}$ & 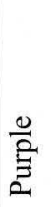 & 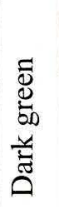 & 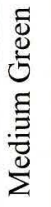 & 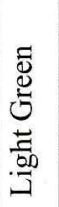 & 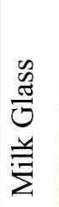 & 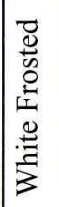 & 莺 & 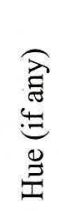 & 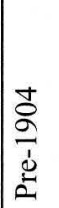 & $\begin{array}{l}\stackrel{\circ}{\sigma} \\
\frac{1}{2} \\
\stackrel{5}{g}\end{array}$ & 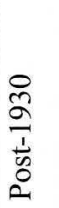 & Remarks & 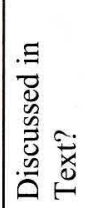 \\
\hline 30 & 1 & 5 & $\mathrm{x}$ & & & & & $\mathrm{x}$ & & & & & & & & $\mathrm{x}$ & & & etched; molded design & $\mathrm{x}$ \\
\hline 30 & 1 & 3 & $\mathrm{x}$ & & & & & & $\mathrm{x}$ & & & & & & & $\mathrm{x}$ & & & & \\
\hline 30 & 1 & 1 & & $\mathrm{x}$ & & & & & $\mathrm{x}$ & & & & & & & $\mathrm{x}$ & & & & \\
\hline 30 & 2 & 5 & - & $\mathrm{x}$ & & & & & $\mathrm{x}$ & & & & & & & $\mathrm{x}$ & & & & \\
\hline- & Sndbx & 1 & $\mathrm{x}$ & & & $\mathrm{x}$ & & & & & & & & & & $\mathrm{x}$ & & & stopper neck; 'medicine' bottle; blow-back seams & $\mathrm{x}$ \\
\hline $20 \& 22$ & Surf. & 1 & $\mathrm{x}$ & & & & & & $\mathrm{x}$ & & & & & & & $\mathrm{x}$ & & & & \\
\hline Fea. 4 & Surf. & 12 & $\mathrm{x}$ & & & $\mathrm{x}$ & & & & & & & & & & $\mathrm{x}$ & & & heavily patinated & \\
\hline Site & Surf. & 1 & $\mathrm{x}$ & & & & $\mathrm{x}$ & & & & & & & & & $\mathrm{x}$ & & & stopper neck & \\
\hline Site & Surf. & 3 & $\mathrm{x}$ & & & & & & $\mathrm{x}$ & & & & & & & $\mathrm{x}$ & & & raised lettering & \\
\hline ST 4 & 1 & 1 & $\mathrm{x}$ & & & & & $\mathrm{x}$ & & & & & & & & $\mathrm{x}$ & & & & \\
\hline $\operatorname{Tr}-1 \mathrm{~A}$ & 1 & 1 & $\mathrm{x}$ & & & & $\mathrm{x}$ & & & & & & & & & $\mathrm{x}$ & & & & \\
\hline $\operatorname{Tr}-1 \mathrm{~A}$ & 1 & 2 & $\mathrm{x}$ & & $\mathrm{x}$ & & & & & & & & & & & $\mathrm{x}$ & & & & \\
\hline $\operatorname{Tr}-1 \mathrm{~A}$ & 1 & 1 & & $\mathrm{x}$ & & & & $\mathrm{x}$ & & & & & & & & $\mathrm{x}$ & & & heavily patinated & \\
\hline $\operatorname{Tr}-1 \mathrm{~A}$ & 1 & 1 & $\mathrm{x}$ & & & & & $\mathrm{x}$ & & & & & & & & $x$ & & & heavily patinated & \\
\hline Tr-1A & 1 & 1 & $\mathrm{x}$ & & & & & & $\mathrm{x}$ & & & & & & & $\mathrm{x}$ & & & & \\
\hline $\mathrm{Tr}-1 \mathrm{~B}$ & 1 & 4 & $\mathrm{x}$ & & $\mathrm{x}$ & & & & & & & & & & & $\mathrm{x}$ & & & raised lettering & \\
\hline
\end{tabular}


Appendix B

\section{Window Glass Thickness}

David L. Nickels

\begin{tabular}{|c|c|c|c|c|c|c|c|c|}
\hline Unit & Level & Thickness & Unit & Level & Thickness & Unit & Level & Thickness \\
\hline 1 & 2 & 1.6 & 15 & 1 & 2.3 & TR-1A & 1 & 2 \\
\hline 2 & 1 & 1.7 & 15 & 1 & 2.4 & TR-1A & 1 & 2.7 \\
\hline 2 & 1 & 1.9 & 15 & 1 & 2.7 & TR-1B & 1 & 1 \\
\hline 2 & 1 & 1.9 & 15 & 2 & 2.3 & TR-1B & 1 & 1.1 \\
\hline 2 & 1 & 2 & 15 & 2 & 2.5 & TR-1B & 1 & 1.3 \\
\hline 2 & 1 & 2 & 18 & 3 & 2.3 & TR-1B & 1 & 1.3 \\
\hline 2 & 1 & 2.1 & 22 & 1 & 1.8 & & & \\
\hline 2 & 1 & 2.2 & 22 & 1 & 2.1 & & & \\
\hline 2 & 1 & 2.3 & 22 & 1 & 2.3 & & & \\
\hline 2 & 1 & 2.3 & 22 & 1 & 2.4 & & & \\
\hline 5 & 1 & 1.9 & 22 & 1 & 2.4 & & & \\
\hline 5 & 1 & 1.9 & 22 & 1 & 2.5 & & & \\
\hline 5 & 1 & 2 & 22 & 1 & 2.5 & & & \\
\hline 6 & 1 & 2.4 & 22 & 1 & 2.6 & & & \\
\hline 6 & 2 & 1.5 & 22 & 1 & 2.7 & & & \\
\hline 6 & 2 & 1.8 & 22 & 1 & 2.7 & & & \\
\hline 8 & 2 & 2.2 & 22 & 1 & 2.8 & & & \\
\hline 9 & 1 & 2.4 & 22 & 3 & 2.3 & & & \\
\hline 9 & 1 & 2.8 & 22 & 3 & 2.5 & & & \\
\hline 9 & 2 & 1.4 & 23 & 3 & 1.8 & & & \\
\hline 9 & 2 & 2.2 & 23 & 3 & 2.4 & & & \\
\hline 9 & 2 & 2.5 & 23 & 4 & 2.1 & & & \\
\hline 9 & 2 & 2.7 & 23 & 4 & 2.5 & & & \\
\hline 12 & 1 & 1.3 & 24 & 1 & 2.5 & & & \\
\hline 12 & 1 & 1.5 & 26 & 1 & 2.2 & & & \\
\hline 12 & 1 & 1.7 & 26 & 1 & 2.3 & & & \\
\hline 12 & 1 & 1.9 & 26 & 1 & 2.3 & & & \\
\hline 12 & 1 & 2 & 26 & 1 & 2.3 & & & \\
\hline 12 & 1 & 2 & 26 & 1 & 2.5 & & & \\
\hline 12 & 1 & 2.2 & 26 & 1 & 2.5 & & & \\
\hline 12 & 1 & 2.3 & 26 & 1 & 2.5 & & & \\
\hline 12 & 1 & 2.4 & 26 & 1 & 2.5 & & & \\
\hline 12 & 1 & 2.4 & 26 & 1 & 2.7 & & & \\
\hline 12 & 1 & 2.5 & 26 & 1 & 2.8 & & & \\
\hline 12 & 1 & 2.6 & 26 & 3 & 1.8 & & & \\
\hline 12 & 1 & 2.6 & 26 & 3 & 2.4 & & & \\
\hline 12 & 1 & 2.6 & 28 & 1 & 2.4 & & & \\
\hline 12 & 1 & 3.1 & 28 & 1 & 2.5 & & & \\
\hline 12 & 2 & 2 & TR-1A & 1 & 1 & & & \\
\hline 12 & 2 & 2.3 & TR-1A & 1 & 1 & & & \\
\hline 12 & 2 & 2.4 & TR-1A & 1 & 1.1 & & & \\
\hline 12 & 2 & 2.6 & TR-1A & 1 & 1.2 & & & \\
\hline 12 & 3 & 2.4 & TR-1A & 1 & 1.2 & & & \\
\hline 12 & 3 & 2.5 & TR-1A & 1 & 1.3 & & & \\
\hline 12 & 3 & 2.6 & TR-1A & 1 & 1.3 & & & \\
\hline 13 & 1 & 1.5 & TR-1A & 1 & 1.4 & & & \\
\hline 13 & 1 & 2.5 & TR-1A & 1 & 1.6 & & & \\
\hline 15 & 1 & 2.2 & TR-1A & 1 & 1.7 & & & \\
\hline
\end{tabular}




\section{Appendix C}

\section{Ceramics}

David L. Nickels

\begin{tabular}{|c|c|c|c|c|c|c|}
\hline Unit & Level & 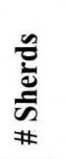 & Category & Remarks & Age & 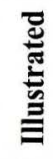 \\
\hline 1 & 1 & 1 & Edgeware & Cockled, impressed, blue & $1795-1825$ & $\mathrm{x}$ \\
\hline 1 & 1 & 11 & Undecorated Whiteware & Plate, saucer & 1850 -present & \\
\hline 1 & 1 & 2 & Stoneware & Body sherd; Albany exterior/Albany interior & $1875-1900$ & \\
\hline 1 & 1 & 1 & Transferware & Blue & $1880-1900$ & \\
\hline 1 & 1 & 2 & Earthenware & Glazed & $1970 \mathrm{~s}$ & \\
\hline 1 & 1 & 1 & Red clay & Pipe bowl fragment & Indeterminate & $\mathrm{x}$ \\
\hline 1 & 1 & 1 & Vitrified sewer pipe & & Post-1900 & \\
\hline 2 & 1 & 1 & Stoneware & Body sherd; salt exterior/Albany interior & $1850-1900$ & \\
\hline 2 & 1 & 1 & Stoneware & Body sherd; salt exterior/Albany interior & $1850-1900$ & \\
\hline 2 & 1 & 13 & Undecorated whiteware & Plate, bowl & 1850 -present & \\
\hline 2 & 1 & 1 & Stoneware & Handle fragment; Albany & $1875-1900$ & \\
\hline 2 & 1 & 10 & Earthenware & Unglazed & $1970 \mathrm{~s}$ & \\
\hline 2 & 1 & 4 & Earthenware & Unglazed w/blue paint & $1970 \mathrm{~s}$ & \\
\hline 2 & 1 & 3 & Stoneware & Appears to be modern & $1970 \mathrm{~s}$ & \\
\hline 2 & 2 & 4 & Undecorated whiteware & Plate & 1850-present & \\
\hline 2 & 2 & 1 & Earthenware & Glazed & $1970 \mathrm{~s}$ & \\
\hline 2 & 2 & 1 & Stoneware & Appears to be modern & $1970 \mathrm{~s}$ & \\
\hline 3 & 1 & 2 & Undecorated whiteware & & 1850 -present & \\
\hline 3 & 1 & 1 & Earthenware & Glazed & $1970 \mathrm{~s}$ & \\
\hline 3 & 2 & 1 & Undecorated whiteware & & 1850-present & \\
\hline 4 & 1 & 1 & Earthenware & Flower pot & Modern & \\
\hline 5 & 1 & 1 & Spatterware & Blue & $1800-1850$ & \\
\hline 5 & 1 & 12 & Undecorated whiteware & Plate, saucer & 1850 -present & 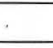 \\
\hline 5 & 1 & 1 & Earthenware & Flower pot & Indeterminate & \\
\hline 6 & 1 & 3 & Earthenware & Glazed \& unglazed; 'John 75 ' & 1975 & \\
\hline 6 & 1 & 2 & Undecorated whiteware & & 1850 -present & \\
\hline 6 & 1 & 1 & Earthenware & Glazed & $1970 \mathrm{~s}$ & \\
\hline 6 & 2 & 1 & Stoneware & Body sherd; salt exterior (interior missing) & $1850-1900$ & \\
\hline 6 & 2 & 1 & White clay & Bottle neck, embossed, unidentified maker's mark & $1850-1900$ & $\mathrm{x}$ \\
\hline
\end{tabular}




\section{Appendix C}

\section{Ceramics}

\begin{tabular}{|c|c|c|c|c|c|c|}
\hline Unit & Level & $\frac{\mathscr{Z}}{\tilde{\Xi}}$ & Category & Remarks & Age & 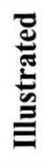 \\
\hline 6 & 2 & 3 & Undecorated whiteware & Bowl & 1850 -present & \\
\hline 7 & 1 & 1 & Stoneware & Body sherd; salt exterior; Albany interior & $1850-1900$ & \\
\hline 7 & 1 & 2 & Undecorated whiteware & Plate & 1850 -present & \\
\hline 7 & 1 & 1 & Handpainted & Large floral pattern; red & $1870-1900$ & \\
\hline 7 & 1 & 4 & Earthenware & Glazed \& unglazed & $1970 \mathrm{~s}$ & \\
\hline 8 & 1 & 1 & Porcelain & Undecorated & 1840-present & \\
\hline 8 & 1 & 8 & Earthenware & Glazed & $1970 \mathrm{~s}$ & \\
\hline 8 & 2 & 4 & Undecorated whiteware & Bowl & 1850-present & \\
\hline 8 & 2 & 1 & Handpainted & Large floral pattern; red & $1870-1900$ & \\
\hline 8 & 2 & 1 & Transferware & Blue & $1880-1900$ & \\
\hline 8 & 2 & 2 & Earthenware & Glazed \& unglazed & $1970 \mathrm{~s}$ & \\
\hline 8 & 2 & 1 & Earthenware & Glazed & $1970 \mathrm{~s}$ & \\
\hline 9 & 1 & 1 & Grey clay & Pipe bowl fragment & $1850-1900$ & $\mathrm{x}$ \\
\hline 9 & 1 & 3 & Undecorated whiteware & & 1850-present & \\
\hline 9 & 1 & 7 & Undecorated whiteware & Plate & 1850-present & \\
\hline 9 & 1 & 1 & Band and line & Red & 1875-present & \\
\hline 9 & 1 & 3 & Transferware & Blue & $1880-1900$ & \\
\hline 9 & 1 & 1 & Earthenware & Glazed \& unglazed & $1970 \mathrm{~s}$ & \\
\hline 9 & 2 & 5 & Undecorated whiteware & Cup & 1850-present & \\
\hline 9 & 2 & 1 & Transferware & Blue & $1880-1900$ & \\
\hline 10 & 1 & 2 & Undecorated whiteware & & 1850 -present & \\
\hline 10 & 1 & 1 & Brick & Yellow & Indeterminate & \\
\hline 10 & 1 & 1 & Stoneware & Handle fragment; Bristol & Post-1900 & \\
\hline 11 & 1 & 1 & Stoneware & Appears to be modern & $1970 \mathrm{~s}$ & \\
\hline 11 & 2 & 1 & Spatterware & Blue & $1800-1850$ & \\
\hline 11 & 2 & 1 & Porcelain & Undecorated & 1840-present & \\
\hline 11 & 2 & 9 & Undecorated whiteware & Cup & 1850-present & \\
\hline 11 & 2 & 1 & Transferware & Blue & $1880-1900$ & \\
\hline 12 & 1 & 1 & Handpainted & Small sprig pattern; green & $1840-1870$ & \\
\hline
\end{tabular}


Appendix C

\section{Ceramics}

\begin{tabular}{|c|c|c|c|c|c|c|}
\hline Unit & Level & 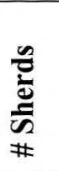 & Category & Remarks & Age & 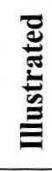 \\
\hline 12 & 1 & 1 & Porcelain & Undecorated & 1840-present & \\
\hline 12 & 1 & 3 & Transferware & Blue & $1880-1900$ & \\
\hline 12 & 1 & 1 & Earthenware & Glazed & $1970 \mathrm{~s}$ & \\
\hline 12 & 2 & 5 & Undecorated whiteware & Plate & 1850-present & \\
\hline 12 & 2 & 1 & Stoneware & Appears to be modern & $1970 \mathrm{~s}$ & \\
\hline 12 & 3 & 1 & Handpainted & Large floral pattern; black, blue, green & $1870-1900$ & \\
\hline 13 & 1 & 5 & Undecorated whiteware & One with an ' 8 ' embossed on the bottom & 1850-present & \\
\hline 13 & 2 & 1 & Porcelain & Undecorated & 1840-present & \\
\hline 13 & 2 & 3 & Undecorated whiteware & & 1850-present & \\
\hline 13 & 2 & 2 & Earthenware & Glazed & $1970 \mathrm{~s}$ & \\
\hline 14 & 1 & 1 & Yellowware & (Liebowitz 1985) & $1850-1900$ & \\
\hline 14 & 1 & 6 & Undecorated whiteware & & 1850-present & \\
\hline 16 & 2 & 7 & Undecorated whiteware & & 1850-present & \\
\hline 16 & 2 & 1 & Decalcomania & Light green leaf pattern & Post-1850s & $\mathrm{x}$ \\
\hline 17 & 1 & 2 & Undecorated whiteware & & 1850 -present & \\
\hline 17 & 1 & 1 & Transferware & Blue & $1880-1900$ & \\
\hline 17 & 1 & 1 & Earthenware & Glazed & $1970 \mathrm{~s}$ & \\
\hline 18 & 3 & 3 & Undecorated whiteware & One w/raised molded design & 1850 -present & \\
\hline 19 & 1 & 2 & Undecorated whiteware & & 1850 -present & \\
\hline 20 & 1 & 1 & Porcelain & Undecorated & 1840-present & \\
\hline 20 & 1 & 5 & Undecorated whiteware & & 1850-present & \\
\hline
\end{tabular}


Appendix C

Ceramics

(continued)

David L. Nickels

\begin{tabular}{|c|c|c|c|c|c|c|}
\hline Unit & Level & 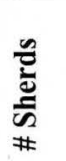 & Category & Remarks & Age & 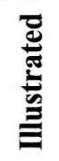 \\
\hline 20 & 2 & 1 & Undecorated whiteware & & 1850-present & \\
\hline 21 & 1 & 2 & Porcelain & Undecorated & 1840-present & \\
\hline 21 & 1 & 2 & Earthenware & Glazed and unglazed & 1970s & \\
\hline 21 & 2 & 4 & Undecorated whiteware & All w/raised molded design & 1850-present & \\
\hline 21 & 3 & 5 & Undecorated whiteware & & 1850-present & \\
\hline 21 & 3 & 1 & Transferware & Light blue & $1880-1900$ & \\
\hline 21 & 4 & 3 & Undecorated whiteware & & 1850-present & \\
\hline 22 & 1 & 5 & Undecorated whiteware & & 1850-present & \\
\hline 22 & 1 & 2 & Earthenware & Glazed & $1970 \mathrm{~s}$ & \\
\hline 22 & 2 & 1 & Earthenware & Glazed & $1970 \mathrm{~s}$ & \\
\hline 22 & 3 & 1 & Transferware & Blue & $1880-1900$ & \\
\hline 23 & 1 & 1 & Spatterware & Blue & $1800-1850$ & \\
\hline 23 & 1 & 1 & Porcelain & Undecorated & 1840-present & \\
\hline 23 & 1 & 4 & Undecorated whiteware & & 1850-present & \\
\hline 23 & 1 & 1 & Earthenware & Unglazed & $1970 \mathrm{~s}$ & \\
\hline 23 & 1 & 1 & Brick & Red brick, painted yellow and blue & Indeterminate & \\
\hline 23 & 2 & 11 & Undecorated whiteware & & 1850-present & \\
\hline 23 & 2 & 3 & Earthenware & Glazed and unglazed & $1970 \mathrm{~s}$ & \\
\hline 23 & 3 & 10 & Undecorated whiteware & One w/raised molded design & $1850-$ present & \\
\hline 23 & 3 & 1 & Transferware & Blue & $1880-1900$ & \\
\hline 23 & 3 & 1 & Kaolin & Pipe stem fragment & Indeterminate & $\mathrm{x}$ \\
\hline 23 & 4 & 1 & Cut sponge & Red & $1845-1900$ & \\
\hline 23 & 4 & 1 & Stoneware & Salt exterior/Albany interior & $1850-1900$ & \\
\hline 23 & 4 & 3 & Undecorated whiteware & One sherd refits to another in Unit 30, Level 1 & 1850-present & \\
\hline 23 & 4 & 1 & Transferware & Blue & $1880-1900$ & \\
\hline 23 & 4 & 1 & Decorated whiteware & Salt glazed and polychrome painted exterior & Indeterminate & $\mathrm{x}$ \\
\hline 23 & 5 & 1 & Earthenware & Unglazed & $1970 \mathrm{~s}$ & \\
\hline 24 & 1 & 1 & Spatterware & Blue & $1800-1850$ & \\
\hline 24 & 1 & 1 & Handpainted & Small sprig pattern; red, blue, green & $1840-1870$ & \\
\hline
\end{tabular}




\section{Appendix C}

\section{Ceramics}

(continued)

David L. Nickels

\begin{tabular}{|c|c|c|c|c|c|c|}
\hline Unit & Level & 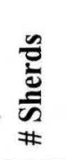 & Category & Remarks & Age & 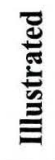 \\
\hline 24 & -1 & 7 & Undecorated whiteware & Cup & 1850-present & \\
\hline 24 & 1 & 3 & Transferware & Blue & $1880-1900$ & \\
\hline 24 & 1 & 1 & Earthenware & Glazed \& unglazed & 1970s & \\
\hline 24 & 1 & 1 & Banded ware & Blue & ca. $1930 \mathrm{~s}$ & \\
\hline 24 & 1 & 1 & Transferware & Sepia & Pre-1900 & \\
\hline 24 & 2 & 1 & Handpainted & Small sprig pattern; black, blue, green & $1840-1870$ & \\
\hline 24 & 2 & 3 & Transferware & Blue & $1880-1900$ & \\
\hline 24 & 2 & 2 & Transferware & Blue & $1880-1900$ & \\
\hline 24 & 2 & 1 & Earthenware & Glazed & $1970 \mathrm{~s}$ & \\
\hline 24 & 2 & 1 & Transferware & Green & Pre-1900 & \\
\hline 25 & 1 & 1 & Porcelain & China Doll leg & $1850-1915$ & $\mathrm{x}$ \\
\hline 26 & 1 & 2 & Spatterware & Blue & $1800-1850$ & \\
\hline 26 & 1 & 1 & Undecorated whiteware & Molded & 1850-present & \\
\hline 26 & 1 & 10 & Undecorated whiteware & Sugar bowl? & 1850-present & \\
\hline 26 & 1 & 1 & Handpainted & Large floral pattern; red & $1870-1900$ & \\
\hline 26 & 1 & 1 & Copper tea leaf & 'Luster banded and spray' & $1880 \mathrm{~s}-1910$ & \\
\hline 26 & 1 & 1 & Transferware & Blue & $1880-1900$ & \\
\hline 26 & 1 & 4 & Stoneware & Appears to be modern & 1970s & \\
\hline 26 & 2 & 1 & Undecorated whiteware & & 1850-present & \\
\hline 26 & 3 & 1 & Undecorated whiteware & & 1850 -present & \\
\hline 26 & 3 & 8 & Earthenware & Glazed and unglazed & $1970 \mathrm{~s}$ & \\
\hline 27 & 1 & 1 & Undecorated whiteware & Bowl & 1850-present & \\
\hline 27 & 1 & 4 & Undecorated whiteware & & 1850-present & \\
\hline 27 & 1 & 1 & Earthenware & Flower pot & Modern & \\
\hline 27 & 2 & 1 & Stoneware & Salt exterior/Albany interior & $1850-1900$ & \\
\hline 28 & 1 & 2 & Transferware & Molded, blue & $1880-1900$ & \\
\hline 30 & 1 & 4 & Undecorated whiteware & One sherd refits to another in Unit 23 , Level 4 & 1850-present & \\
\hline 30 & 2 & 3 & Undecorated whiteware & & 1850 -present & \\
\hline 30 & 2 & 1 & Transferware & Blue & $1880-1900$ & \\
\hline
\end{tabular}




\section{Appendix C}

\section{Ceramics}

\begin{tabular}{|c|c|c|c|c|c|c|}
\hline Unit & Level & 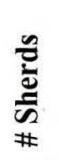 & Category & Remarks & Age & 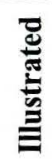 \\
\hline 30 & 2 & 1 & Earthenware & Glazed & $1970 \mathrm{~s}$ & \\
\hline 30 & 3 & 4 & Undecorated whiteware & & 1850-present & \\
\hline Fea 4 & 2 & 1 & Undecorated whiteware & Unidentifiable maker's mark & 1850-present & \\
\hline Fea 4 & Fig F & 3 & Transferware & Blue & $1880-1900$ & \\
\hline Fea 4 & Fig K & 2 & Undecorated whiteware & & 1850-present & \\
\hline Fea 4 & Surface & 2 & Stoneware & Body sherd; alkaline exterior/alkaline interior & $1850-1900$ & \\
\hline Fea 4 & Surface & 1 & Stoneware & Body sherd; salt exterior (interior missing) & $1850-1900$ & \\
\hline Fea 4 & Surface & 1 & Undecorated whiteware & Plate & 1850-present & \\
\hline Fea 4 & Surface & 1 & Transferware & Molded, blue & $1880-1900$ & \\
\hline Fea 4 & Surface & 4 & Earthenware & Glazed & $1970 \mathrm{~s}$ & \\
\hline Fea 4 & Surface & 1 & Transferware & English Registry mark; 'horse catcher' & Post- 1853 & $\mathrm{x}$ \\
\hline Fea C & Fig 4 & 1 & Transferware & Blue & $1880-1900$ & \\
\hline Mock & Surface & 1 & Stoneware & Appears to be modern & $1970 \mathrm{~s}$ & \\
\hline Site & Surface & 2 & Earthenware & Glazed \& unglazed & $1970 \mathrm{~s}$ & \\
\hline ST2 & 2 & 1 & Undecorated whiteware & & 1850-present & \\
\hline ST2 & 2 & 1 & Stoneware & Appears to be modern & $1970 \mathrm{~s}$ & \\
\hline ST4 & 1 & 1 & Transferware & 'F.W. Winkle \& Co' maker's mark & $1890-1925$ & $\mathrm{x}$ \\
\hline ST5 & 1 & 1 & Undecorated whiteware & Cup & 1850 -present & \\
\hline ST6 & 1 & 1 & Undecorated whiteware & Sugar bowl & 1850-present & \\
\hline ST8 & 1 & 1 & Undecorated whiteware & & $1850-$ present & \\
\hline ST8 & 1 & 1 & Ironstone & 'Morley \& Co' maker's mark & $1879-1884$ & $\mathrm{x}$ \\
\hline TR1A & 1 & 1 & Cut sponge & Red and yellow floral design & $1845-1900$ & \\
\hline TR1A & 1 & 1 & Stoneware & Body sherd; alkaline exterior and interior & $1850-1900$ & \\
\hline TR1A & 1 & 3 & Undecorated whiteware & & 1850-present & \\
\hline TR1A & 1 & 1 & Transferware & Blue & $1880-1900$ & \\
\hline TR1A & 1 & 1 & Earthenware & Flower pot & Modern & \\
\hline TR1B & 1 & 1 & Handpainted & Small sprig pattern; black, blue, green & $1840-1870$ & \\
\hline TR1B & 1 & 8 & Undecorated whiteware & Cream pitcher snout & 1850-present & \\
\hline TR1B & 1 & 1 & Indeterminate & Blue & Indeterminate & \\
\hline
\end{tabular}




\section{Appendix C}

\section{Ceramics}

(continued)

David L. Nickels

\begin{tabular}{|c|c|c|c|c|c|c|}
\hline Unit & Level & 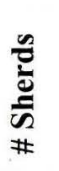 & Category & Remarks & Age & 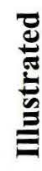 \\
\hline TR1B & 1 & 1 & Ironstone & 'J\&G Meakin' maker's mark & Post-1937 & $\mathrm{x}$ \\
\hline Unknown & Surface & 6 & Undecorated whiteware & & 1850-present & \\
\hline & Total & 413 & & & & \\
\hline
\end{tabular}




\section{Appendix D}

\section{Nails, Bolts, and Screws}

David L. Nickels

\begin{tabular}{|c|c|c|c|c|c|}
\hline Unit & Level & Cut or Square Nails & Round Nails & Screws \& Bolts & Total \\
\hline Trench 1A & 1 & 18 & 4 & 1 & 23 \\
\hline Trench 1B & 2 & 2 & 2 & 0 & 4 \\
\hline Trench 1B & 1 & 17 & 1 & 1 & 19 \\
\hline 1 & 1 & 38 & 2 & 1 & 41 \\
\hline 1 & 2 & 5 & 0 & 0 & 5 \\
\hline 2 & 1 & 25 & 4 & 2 & 31 \\
\hline 2 & 2 & 5 & 3 & 0 & 8 \\
\hline 3 & 1 & 8 & 0 & 0 & 8 \\
\hline 3 & 2 & 6 & 0 & 0 & 6 \\
\hline 5 & 1 & 9 & 7 & 1 & 17 \\
\hline 6 & 1 & 10 & 1 & 0 & 11 \\
\hline 6 & 2 & 12 & 0 & 0 & 12 \\
\hline 7 & 1 & 8 & 2 & 0 & 10 \\
\hline 8 & 1 & 14 & 4 & 0 & 18 \\
\hline 8 & 2 & 27 & 1 & 1 & 29 \\
\hline 9 & 1 & 6 & 1 & 0 & 7 \\
\hline 9 & 2 & 3 & 0 & 0 & 3 \\
\hline 10 & 1 & 24 & 1 & 0 & 25 \\
\hline 11 & 1 & 25 & 5 & 0 & 30 \\
\hline 11 & 2 & 16 & 0 & 0 & 16 \\
\hline 12 & 1 & 13 & 0 & 0 & 13 \\
\hline 12 & 2 & 5 & 0 & 0 & 5 \\
\hline 12 & 3 & 4 & 0 & 0 & 4 \\
\hline 13 & 1 & 22 & 5 & 0 & 27 \\
\hline 13 & 2 & 30 & 3 & 0 & 33 \\
\hline 14 & 1 & 34 & 1 & 0 & 35 \\
\hline 14 & 2 & 2 & 0 & 0 & 2 \\
\hline 15 & 1 & 5 & 4 & 0 & 9 \\
\hline 15 & 2 & 4 & 0 & 0 & 4 \\
\hline 16 & 1 & 20 & 1 & 0 & 21 \\
\hline 16 & 2 & 30 & 3 & 0 & 33 \\
\hline 16 & 3 & 17 & 1 & 0 & 18 \\
\hline 16 & 4 & 3 & 0 & 0 & 3 \\
\hline 17 & 1 & 7 & 0 & 0 & 7 \\
\hline 18 & 2 & 13 & 2 & 0 & 15 \\
\hline 18 & 3 & 38 & 0 & 0 & 38 \\
\hline 19 & 1 & 6 & 1 & 0 & 7 \\
\hline 20 & 1 & 16 & 9 & 0 & 25 \\
\hline 20 & 2 & 7 & 0 & 0 & 7 \\
\hline 21 & 1 & 3 & 1 & 0 & 4 \\
\hline 21 & 2 & 5 & 0 & 0 & 5 \\
\hline 21 & 3 & 45 & 0 & 1 & 46 \\
\hline 21 & 4 & 2 & 0 & 0 & 2 \\
\hline
\end{tabular}


Appendix D. Nails, Bolts, and Screws (continued)

\begin{tabular}{|c|c|c|c|c|c|}
\hline Unit & Level & Cut or Square Nails & Round Nails & Screws \& Bolts & Total \\
\hline 21 & 5 & 0 & 1 & 0 & 1 \\
\hline 22 & 1 & 21 & 1 & 0 & 22 \\
\hline 22 & 3 & 2 & 0 & 0 & 2 \\
\hline 23 & 1 & 13 & 1 & 0 & 14 \\
\hline 23 & 2 & 50 & 5 & 0 & 55 \\
\hline 23 & 3 & 48 & 5 & 0 & 53 \\
\hline 23 & 4 & 31 & 0 & 2 & 33 \\
\hline 23 & 5 & 2 & 0 & 0 & 2 \\
\hline 24 & 1 & 24 & 0 & 0 & 24 \\
\hline 24 & 2 & 3 & 0 & 0 & 3 \\
\hline 25 & 1 & 8 & 0 & 0 & 8 \\
\hline 25 & 2 & 25 & 0 & 0 & 25 \\
\hline 26 & 1 & 20 & 2 & 0 & 22 \\
\hline 26 & 2 & 4 & 1 & 0 & 5 \\
\hline 26 & 3 & 8 & 1 & 0 & 9 \\
\hline 27 & 1 & 0 & 1 & 0 & 1 \\
\hline 27 & 2 & 35 & 0 & 0 & 35 \\
\hline 28 & 1 & 6 & 0 & 0 & 6 \\
\hline 29 & 2 & 3 & 0 & 1 & 4 \\
\hline 30 & 1 & 17 & 0 & 0 & 17 \\
\hline 30 & 2 & 59 & 5 & 0 & 64 \\
\hline 30 & 3 & 14 & 1 & 0 & 15 \\
\hline ST 1 & 2 & 1 & 0 & 0 & 1 \\
\hline ST 2 & 1 & 1 & 0 & 0 & 1 \\
\hline ST 4 & 1 & 3 & 1 & 0 & 4 \\
\hline ST 6 & 1 & 2 & 0 & 0 & 2 \\
\hline ST 6 & 2 & 4 & 0 & 0 & 4 \\
\hline ST 7 & 1 & 1 & 0 & 0 & 1 \\
\hline ST 8 & 1 & 8 & 5 & 0 & 13 \\
\hline Feature 4 & Surface & 1 & 0 & 0 & 1 \\
\hline Feature 4 & Surface & 1 & 0 & 0 & 1 \\
\hline Feature 4 & Surface & 2 & 0 & 0 & 2 \\
\hline 20 and 22 & Surface & 7 & 5 & 0 & 12 \\
\hline & Totals & 1,033 & 104 & 11 & 1,148 \\
\hline
\end{tabular}


Appendix E

Metal Items

David L. Nickels

\begin{tabular}{|c|c|c|c|}
\hline Unit & Level & Description & $\begin{array}{c}\text { Probable } \\
\text { Date }\end{array}$ \\
\hline 1 & 1 & 1/8-inch thick $x$ 1-inch wide iron piece $\mathrm{w} / \mathrm{a}$ ' $\mathrm{V}$ '-shaped hole in the middle & \\
\hline 2 & 1 & Ferrous, 2-inch cotter pin & \\
\hline 2 & 1 & Aluminum can pop-top & modern \\
\hline 2 & 2 & Unidentifiable ferrous scrap & \\
\hline 2 & Surface & 1/8-inch thick x 7-inch long iron fragment; probable stove part & \\
\hline 5 & 1 & Unidentifiable ferrous scrap & \\
\hline 5 & 1 & Electrical wire end connector & \\
\hline 6 & 1 & 11 aluminum pulltabs & modern \\
\hline 6 & 1 & 1/8-inch flat washer & \\
\hline 6 & 1 & 3/16-inch shoelace eyelet & \\
\hline 6 & 1 & 1/32-inch wire ( 2 pieces $)$ & \\
\hline 8 & 1 & Small belt buckle & \\
\hline 8 & 1 & Crown bottle cap & \\
\hline 8 & 1 & Tin scrap & \\
\hline 8 & 1 & Winchester New rival .12 gauge shotgun shell base & \\
\hline 8 & 1 & Television antenna wire & modern \\
\hline 8 & 1 & Rubber-covered electrical wire & \\
\hline 8 & 2 & 1/8-inch shoelace eyelets ( 2 each) & \\
\hline 8 & 2 & 1/8-inch lock washer & \\
\hline
\end{tabular}


Appendix E

Metal Items

(continued)

David L. Nickels

\begin{tabular}{|c|c|c|c|}
\hline 8 & 2 & 3/4-inch diameter lead chunk & \\
\hline 8 & 2 & 1/4-inch $\times 5$-inch tin strip & \\
\hline 8 & 2 & Unidentifiable ferrous metal chunks (2 each) & \\
\hline 8 & 2 & Aluminum pulltabs & modern \\
\hline 9 & 1 & Welding slag & \\
\hline 9 & 1 & Thick iron bar, 2.75 inches long & \\
\hline 9 & 1 & Tin can fragments w/crimped sanitary top & post-1903 \\
\hline 9 & 1 & 1/8-inch $\times 2$-inch, flat, thick iron, sharpened on one edge & \\
\hline 9 & 1 & Tin can fragments & \\
\hline 9 & 1 & 6-inch diameter tin lid; probable paint can lid & \\
\hline 9 & 2 & 4-inch $\times$ 6-inch fragmented flat metal with raised $1 / 8$-inch edge, machine tooled & \\
\hline 9 & 2 & Tin can fragment with crimped top & post-1903 \\
\hline 9 & 2 & Tin can fragments & \\
\hline 10 & 1 & .22 caliber short brass casing, rimfire & \\
\hline 10 & 1 & 3-inch long round wire (ferrous) & \\
\hline 10 & 1 & Unidentifiable 3/4-inch flat iron chunk & \\
\hline 10 & 1 & 3-inch long round iron w/iron retainers on each end & \\
\hline 10 & 1 & Wrought iron harness ring w/wear marks & \\
\hline 10 & 1 & 2.75-inch long halter bolt & \\
\hline 11 & 1 & 1/2-inch washer & \\
\hline 11 & 1 & Tin can fragments & \\
\hline 11 & 1 & Tin can rim fragment w/crimped end seam & post-1903 \\
\hline 11 & 1 & Copper harness snap & \\
\hline 11 & 2 & Thin, ferrous ring fragment; otherwise unidentifiable & \\
\hline 12 & 1 & Tin can fragments & \\
\hline 12 & 3 & Ferrule head for hoe, hay fork, shovel, etc. & \\
\hline 12 & 3 & Unidentifiable scrap metal & \\
\hline 13 & 1 & .22 short bullet casing (Logan 1959:63) & post-1857 \\
\hline 13 & 1 & Round wire & \\
\hline 13 & 1 & Round, 1/8-inch flat washer & \\
\hline 13 & 1 & Aluminum pulltab & modern \\
\hline
\end{tabular}




\section{Appendix E}

\section{Metal Items}

(continued)

David L. Nickels

\begin{tabular}{|c|c|c|c|}
\hline 13 & 1 & Unidentifiable iron clasp & \\
\hline 13 & 1 & Unidentifiable metal & \\
\hline 13 & 1 & Square 'toothpick' size and shape piece & \\
\hline 13 & 1 & Rivet & \\
\hline 13 & 2 & Round wire & \\
\hline 13 & 2 & Tin can fragments & \\
\hline 13 & 3 & Tin can fragment & \\
\hline 14 & 1 & Tin can fragments w/crimped seal & post-1903 \\
\hline 14 & 1 & Eyebolt & \\
\hline 14 & 1 & 1/8-inch thick molded or 'ribbed' iron fragment, 3 inches long & \\
\hline 15 & 1 & Forged iron strap, 1 1/2 inches wide $\times 11$ inches long & \\
\hline 15 & 1 & Flattened tin can pecked with nail holes - grate? & \\
\hline 15 & 2 & Tin can fragments & \\
\hline 15 & 2 & 1/8-inch thick x $11 / 2$ inches long iron fragment & \\
\hline 16 & 1 & Unidentifiable chunks & \\
\hline 16 & 3 & .22 short bullet casings, 3 each; (Logan 1959:63) & post-1857 \\
\hline 16 & 3 & Thin sheet iron fragments, 1-inch long & \\
\hline 18 & 1 & 1/8-inch slightly curved iron, 3 inches long, possible stove part & \\
\hline 18 & 2 & Tin can fragments w/crimped seal & post-1903 \\
\hline 18 & 2 & 1/8-inch thick iron fragment, $21 / 2$ inches long & \\
\hline 18 & 3 & Tin can fragments w/crimped seal & post-1903 \\
\hline 18 & 3 & Brass, rimfire, spent bullet casing; .350 caliber for German R.F. Revolver (Logan 1959:66) & post-1900 \\
\hline 19 & 1 & Brass, rimfire, spent bullet casing; .350 caliber for German R.F. Revolver (Logan 1959:66) & post-1900 \\
\hline 20 & 1 & Round wire & \\
\hline 20 & 1 & Heavily rusted and fragmented pocket knife & \\
\hline 20 & 1 & Shoelace eyelet & \\
\hline 20 & 1 & Fish hook & \\
\hline 20 & 2 & Tin can fragment & \\
\hline 20 & Surface & Bed spring coil fragment & \\
\hline 21 & 1 & Metal screw cap w/hard rubber overlay, 'M Co' top in raised letters; water pipe/gas line cap & modern \\
\hline 21 & 1 & Aluminum can pop-top & modern \\
\hline
\end{tabular}


Appendix E

\section{Metal Items}

(continued)

David L. Nickels

\begin{tabular}{|c|c|c|c|}
\hline 21 & 1 & Unidentifiable ferrous metal fragments & \\
\hline 21 & 1 & Tin can fragments, one $\mathrm{w} /$ crimped seal & post-1903 \\
\hline 21 & 1 & Riveted pin (1 $1 / 2$ inches long) & \\
\hline 21 & 3 & Clock key & post-1903 \\
\hline 21 & 3 & Round wire & \\
\hline 21 & 3 & Tin can fragments & \\
\hline 21 & 3 & $1 / 8$-inch thick iron, rounded, $1 / 2$-inch $\times 3$ inches & \\
\hline 21 & 3 & Leather tack & \\
\hline 21 & 4 & Tin can fragment & \\
\hline 21 & 4 & $1 / 8$-inch thick iron, rounded, $3 / 4$ inches long & \\
\hline 22 & 1 & 5-strand wound copper electrical wire & \\
\hline 22 & 1 & Tin can fragments, one w/crimped end seam & post-1903 \\
\hline 22 & 1 & Flat, iron fragment with '..XA...' raised letters, machine forged & \\
\hline 22 & 1 & 'Opposite clinch' iron bracket, hand forged & \\
\hline 22 & 1 & Locking slide buckle for canvas or leather strap & \\
\hline 22 & 1 & Ratcheting stop, machine forged & \\
\hline 22 & 1 & 2 chain links, irregular shapes and lengths suggest they were hand forged & \\
\hline 22 & 1 & Iron bowl, rim is $1 / 16$-inch thick; machine forged & \\
\hline 22 & 1 & Iron mold $(1 / 2)$; unknown purpose & \\
\hline 22 & 1 & Belt buckle (child's?) & \\
\hline 22 & 1 & Railroad spike & \\
\hline 22 & 1 & $1 / 8$-inch thick iron slab, 3.5 inches long & \\
\hline 22 & 1 & 1/8-inch iron strap, 2.25 inches long & \\
\hline 22 & 1 & Possible rifle spring & \\
\hline 22 & 1 & Crimped electrical wire connector (double wire) & \\
\hline 22 & 1 & Window sash latch & \\
\hline 22 & 2 & Tin can fragments & \\
\hline 22 & 3 & Caster roller & \\
\hline 23 & 1 & Vest or pants buckle & \\
\hline 23 & 1 & 67 rivet heads & post- 1960 \\
\hline 23 & 1 & Decorative/award ribbon clasp & \\
\hline
\end{tabular}


Appendix E

\section{Metal Items}

(continued)

David L. Nickels

\begin{tabular}{|c|c|c|c|}
\hline 23 & 1 & Tin can fragment w/crimped seal & post-1903 \\
\hline 23 & 1 & 1/16-inch iron fragments $(<1$-inch long) & \\
\hline 23 & 2 & 16 metal rivet heads of various sizes & post-1960 \\
\hline 23 & 2 & 1/8-inch thick iron pot rim w/machined lip & \\
\hline 23 & 2 & Brass, rimfire, spent bullet casing; .350 caliber for German R.F. Revolver (Logan 1959:66) & post- 1900 \\
\hline 23 & 3 & Eyebolt & \\
\hline 23 & 3 & 1/8-inch thick $\times 1$-inch long iron fragments ( 2 each) & \\
\hline 23 & 3 & Trouser snap & \\
\hline 23 & 3 & Riveted pin (1 $1 / 2$ inches long) & \\
\hline 23 & 4 & Round wire & \\
\hline 23 & 4 & Tin can fragments & \\
\hline 23 & 4 & Unidentifiable clasp & \\
\hline 24 & 1 & 3/8-inch square nut & \\
\hline 24 & 1 & Tin can fragments & \\
\hline 24 & 1 & 1/8-inch thick, round iron pieces, unidentifiable & \\
\hline 24 & 2 & Tin can fragments & \\
\hline 25 & 1 & Tin can fragments & \\
\hline 25 & 1 & Aluminum pulltab & \\
\hline 25 & 1 & Round wire & \\
\hline 25 & 2 & Rivet end & post-1960 \\
\hline 25 & 2 & Iron rivet & \\
\hline 25 & 2 & Spent .22 caliber brass casing & post- 1857 \\
\hline 26 & 1 & Round copper wire & \\
\hline 26 & 1 & 1/8-inch thick $\times 3$-inch long iron fragment & \\
\hline 26 & 1 & Tin can fragments & \\
\hline 26 & 1 & .12 gauge Winchester Repeater shotgun shell base & post-1866 \\
\hline 26 & 2 & Sardine can, crimped seal & post-1903 \\
\hline 26 & 2 & Sickle knife blade from grain or hay mower & \\
\hline 26 & 3 & Television antenna wire & \\
\hline 26 & 3 & Tin can fragment & \\
\hline 27 & 1 & Tin can fragment w/crimped seal & post-1903 \\
\hline
\end{tabular}


Appendix E

\section{Metal Items}

(continued)

David L. Nickels

\begin{tabular}{|c|l|l|l|}
\hline 27 & 1 & Automobile electrical ignition switch (keyed) & post-1920 \\
\hline 27 & 1 & $1 / 8$-inch hex nut & \\
\hline 28 & 1 & Tin can fragment & post-1903 \\
\hline 29 & 1 & Round wire & \\
\hline 29 & 1 & Tin can fragment w/crimped seal & \\
\hline 29 & 2 & Tin can fragment & post-1960s \\
\hline 29 & 2 & $1 / 2$-inch threaded bolt & \\
\hline 30 & 1 & Round wire & post-1960s \\
\hline 30 & 1 & $1 / 16$-inch x 1 1/2-inch iron fragment & $1867-1902$ \\
\hline 30 & 1 & 42 rivet heads & post-1903 \\
\hline 30 & 2 & Round wire & \\
\hline 30 & 2 & tin can fragments & \\
\hline 30 & 2 & 11 rivet heads & post-1960 \\
\hline 30 & 2 & .12 gauge U.M.C. Co. Club shotgun shell base (Logan 1959:8, 10) & \\
\hline Feature 4 & Surface & Sardine can, rusted, opened w/ a can opener - not a key; soldered top and bottom, crimped seal & \\
\hline ST 2 & 1 & Tin can fragments & \\
\hline ST 5 & 1 & Self-seal pop-top (pressure seal); for fruit drink? & \\
\hline ST 7 & 1 & Ferrous, 3/8-inch wide metal chunk, 1/2-inch long x 1/16-inch thick & \\
\hline ST 8 & 1 & 83 rivet heads of various sizes \\
\hline Trench 1A & 1 & Probable iron stove part w/ 'BUCK...' in raised letters & \\
\hline Trench 1A & 1 & Self-seal pop-top (pressure seal); for fruit drink? & \\
\hline Trench 1A & 1 & Tin can fragments & \\
\hline Trench 1A & 1 & Copper key w/ 'J. JERRY \& CO.,' an eagle, and a key stamped into it & \\
\hline Trench 1B & 1 & 1-inch x 1.5-inch metal plate w/ '79' in raised letters; machine made & \\
\hline Trench 1B & 1 & Tin can fragments & \\
\hline
\end{tabular}


Appendix F

\section{Miscellaneous Items and Samples}

David L. Nickels

\begin{tabular}{|c|c|c|c|c|c|}
\hline Unit & Level & Item & Unit & Level & Item \\
\hline 2 & 1 & Thin rubber fragments & 26 & 1 & Charcoal \\
\hline 2 & 1 & Mortar fragments & 26 & 1 & Wood fragments \\
\hline 2 & 2 & Charcoal & 26 & 3 & Charcoal \\
\hline 2 & 2 & Threaded, polished stone furniture knob & 26 & 4 & Charcoal \\
\hline 6 & 1 & Automobile light bulbs ( 2 each) & 27 & 1 & Charcoal \\
\hline 6 & 1 & Plastic strips (2 each) & 27 & 1 & Mortar fragments \\
\hline 6 & 1 & Electrical connector caps ( 3 each) & 27 & 2 & Charcoal \\
\hline 6 & 1 & Mortar fragments & 27 & 2 & Mortar fragments \\
\hline 6 & 2 & Charcoal & 27 & 2 & Wood fragments \\
\hline 7 & 1 & Soft rubber & 29 & 2 & Charcoal \\
\hline 8 & 1 & Artificial (plastic) plant & ST 1 & 1 & Mortar w/red paint \\
\hline 8 & 1 & Clay sample & ST 12 & 2 & Modern pavement \\
\hline 8 & 1 & Charcoal & \begin{tabular}{|l|} 
Trench 1A \\
\end{tabular} & 2 & Charcoal \\
\hline 8 & 2 & Charcoal & & & \\
\hline 9 & 1 & Charcoal & & & \\
\hline 9 & 2 & Charcoal & & & \\
\hline 11 & 2 & Cloth fragment & & & \\
\hline 12 & 1 & Charcoal & & & \\
\hline 12 & 2 & Charcoal & & & \\
\hline 13 & 1 & Plastic fragment & & & \\
\hline 13 & 2 & Charcoal & & & \\
\hline 14 & 1 & Cloth fragment & & & \\
\hline 14 & 2 & Milk glass, inside threaded knob & & & \\
\hline 15 & 1 & Charcoal & & & \\
\hline 15 & 2 & Charcoal & & & \\
\hline 16 & 1 & Charcoal & & & \\
\hline 16 & 1 & Wood fragments & & & \\
\hline 16 & 2 & Charcoal & & & \\
\hline 16 & 2 & Sandstone fragments & & & \\
\hline 16 & 2 & Mortar fragments & & & \\
\hline 16 & 2 & Eggshell fragments & & & \\
\hline 16 & 3 & Charcoal & & & \\
\hline 18 & 2 & Mortar fragments & & & \\
\hline 22 & 1 & Slate pencil & & & \\
\hline 23 & 2 & Slate board fragments & & & \\
\hline 23 & 3 & Pipe stem residue & & & \\
\hline 23 & 4 & Composition, thin tile fragments ( 2 each) & & & \\
\hline 23 & 5 & Slate board fragment & & & \\
\hline 24 & 1 & Charcoal & & & \\
\hline 24 & 2 & Charcoal & & & \\
\hline 25 & 1 & Charcoal & & & \\
\hline 25 & 2 & Plastic and rubber fragments (3 each) & & & \\
\hline 25 & 2 & Charcoal & & & \\
\hline 25 & 2 & Mortar fragments & & & \\
\hline
\end{tabular}




\section{Appendix G}

\section{Chipped Stone}

David L. Nickels

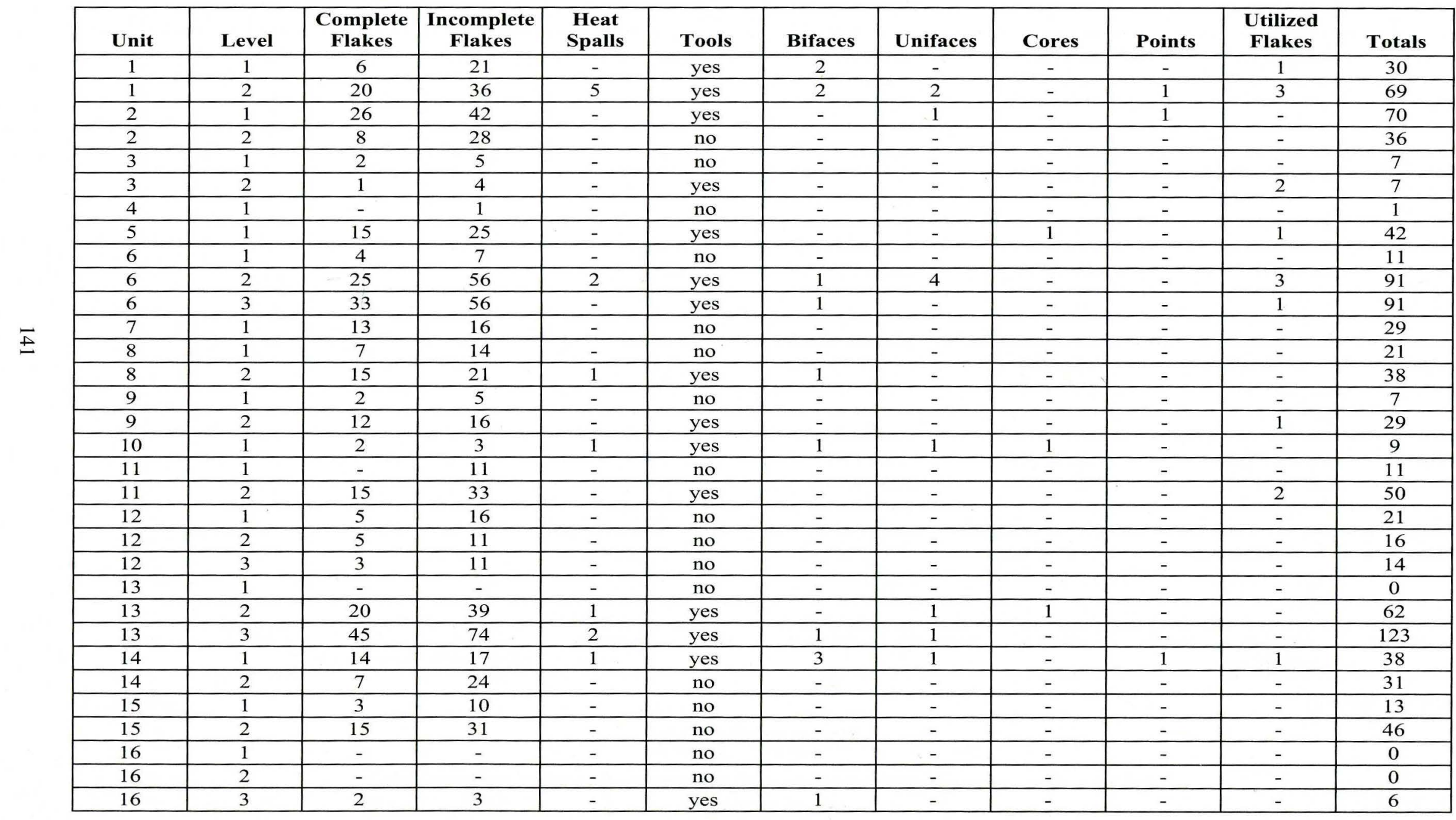




\section{Appendix G}

\section{Chipped Stone}

(continued)

David L. Nickels

\begin{tabular}{|c|c|c|c|c|c|c|c|c|c|c|c|}
\hline Unit & Level & $\begin{array}{c}\text { Complete } \\
\text { Flakes } \\
\end{array}$ & \begin{tabular}{|c|} 
Incomplete \\
Flakes
\end{tabular} & $\begin{array}{c}\text { Heat } \\
\text { Spalls }\end{array}$ & Tools & Bifaces & Unifaces & Cores & Points & $\begin{array}{l}\text { Utilized } \\
\text { Flakes }\end{array}$ & Totals \\
\hline 16 & 4 & - & - & - & no & - & - & - & - & - & 0 \\
\hline 17 & 1 & 1 & 3 & - & no & - & - & - & - & - & 4 \\
\hline 18 & 1 & - & - & - & no & - & - & - & - & - & 0 \\
\hline 18 & 2 & 1 & 2 & - & no & - & - & - & - & - & 3 \\
\hline 18 & 3 & 8 & 30 & 1 & no & - & - & - & - & - & 39 \\
\hline 18 & 4 & - & - & - & no & - & - & - & - & - & 0 \\
\hline 19 & 1 & 25 & 80 & 1 & yes & 2 & 2 & - & - & 2 & 112 \\
\hline 20 & 1 & 4 & 10 & - & yes & - & - & - & - & 1 & 15 \\
\hline 20 & 2 & 9 & 36 & 3 & no & - & - & - & - & - & 48 \\
\hline 20 & 3 & - & 4 & - & no & - & - & - & - & - & 4 \\
\hline 21 & 1 & 1 & 3 & - & yes & - & - & - & - & 1 & 5 \\
\hline 21 & 2 & - & - & - & no & - & - & - & - & - & 0 \\
\hline 21 & 3 & 6 & 35 & 1 & yes & 1 & - & 1 & - & - & 44 \\
\hline 21 & 4 & 80 & 237 & 3 & yes & 2 & - & - & 1 & 1 & 324 \\
\hline 21 & 5 & 4 & 10 & - & no & - & - & - & - & - & 14 \\
\hline 22 & 1 & 2 & 11 & - & yes & 1 & - & - & - & - & 14 \\
\hline 22 & 2 & 3 & 18 & - & no & - & - & - & - & - & 21 \\
\hline 22 & 3 & - & 1 & - & no & - & - & - & - & - & 1 \\
\hline 23 & 1 & 9 & 23 & - & no & - & - & - & - & - & 32 \\
\hline 23 & 2 & 25 & 58 & - & yes & 1 & 1 & - & - & - & 85 \\
\hline 23 & 3 & 6 & 24 & - & no & - & - & - & - & - & 30 \\
\hline 23 & 4 & 5 & 19 & - & yes & - & 1 & - & - & 1 & 26 \\
\hline 23 & 5 & 4 & 8 & 1 & no & - & - & - & - & - & 13 \\
\hline 24 & 1 & 10 & 33 & - & yes & 1 & 2 & - & - & - & 46 \\
\hline 24 & 2 & 20 & 75 & - & yes & - & 1 & 1 & - & - & 97 \\
\hline 25 & 1 & 1 & 2 & 1 & no & - & - & - & - & - & 4 \\
\hline 25 & 2 & 1 & 4 & - & no & - & - & - & - & - & 5 \\
\hline 26 & 1 & 4 & 14 & - & yes & 1 & 1 & - & - & - & 20 \\
\hline 26 & 2 & 3 & - & - & no & - & - & - & - & - & 3 \\
\hline 26 & 3 & 4 & 3 & 1 & no & - & - & - & - & - & 8 \\
\hline 26 & 4 & 1 & - & - & yes & 1 & - & - & - & - & 2 \\
\hline 27 & 1 & 1 & - & - & no & - & - & - & - & - & 1 \\
\hline
\end{tabular}




\section{Appendix G}

\section{Chipped Stone}

(continued)

David L. Nickels

\begin{tabular}{|c|c|c|c|c|c|c|c|c|c|c|c|}
\hline Unit & Level & $\begin{array}{c}\text { Complete } \\
\text { Flakes }\end{array}$ & $\begin{array}{c}\text { Incomplete } \\
\text { Flakes } \\
\end{array}$ & $\begin{array}{c}\text { Heat } \\
\text { Spalls }\end{array}$ & Tools & Bifaces & Unifaces & Cores & Points & $\begin{array}{l}\text { Utilized } \\
\text { Flakes } \\
\end{array}$ & Totals \\
\hline 27 & 2 & - & 1 & - & yes & - & - & 1 & - & - & 2 \\
\hline 28 & 1 & 1 & 5 & - & no & - & - & - & - & - & 6 \\
\hline 29 & 1 & - & - & - & no & - & - & - & - & - & 0 \\
\hline 29 & 2 & - & - & - & no & - & - & - & - & - & 0 \\
\hline 30 & 1 & 4 & 17 & - & no & - & - & - & - & - & 21 \\
\hline 30 & 2 & 3 & 27 & - & yes & 1 & 1 & - & - & 2 & 34 \\
\hline 30 & 3 & 2 & 9 & 1 & yes & - & 1 & - & - & - & 13 \\
\hline Feature 4 & Holes & - & - & - & no & - & - & - & - & - & 0 \\
\hline Feature 4 & Level 1 & - & - & - & no & - & - & - & - & - & 0 \\
\hline Feature 4 & Level 2 & 6 & 14 & - & no & - & - & - & - & - & 20 \\
\hline Feature 4 & Surface & - & 1 & - & no & - & - & - & - & - & 1 \\
\hline Site & Surface & - & - & - & no & - & - & - & - & - & 0 \\
\hline ST 1 & 1 & - & - & - & no & - & - & - & - & - & 0 \\
\hline ST 1 & 2 & - & - & - & no & - & - & - & - & - & 0 \\
\hline ST 10 & 1 & - & - & - & no & - & - & - & - & - & 0 \\
\hline ST 11 & 1 & - & - & - & no & - & - & - & - & - & 0 \\
\hline ST 12 & 1 & - & - & - & no & - & - & - & - & - & 0 \\
\hline ST 12 & 2 & - & - & - & no & - & - & - & - & - & 0 \\
\hline ST 2 & 1 & 1 & 4 & - & no & - & - & - & - & - & 5 \\
\hline ST 3 & 1 & - & 1 & - & no & - & - & - & - & - & 1 \\
\hline ST 3 & 2 & - & 4 & - & no & - & - & - & - & - & 4 \\
\hline ST 4 & 1 & - & 1 & - & yes & 1 & - & - & - & - & 2 \\
\hline ST 5 & 1 & 1 & 3 & - & yes & - & - & - & - & - & 4 \\
\hline ST 6 & 1 & 1 & 3 & - & no & - & - & - & - & - & 4 \\
\hline ST 6 & 2 & 1 & 1 & 1 & no & - & - & - & - & - & 3 \\
\hline ST 7 & 1 & 1 & 4 & - & no & - & - & - & - & - & 5 \\
\hline ST 8 & 1 & - & - & - & no & - & - & - & - & - & 0 \\
\hline ST 9 & 1 & - & - & - & no & - & - & - & - & - & 0 \\
\hline TR 1A & 1 & 4 & 17 & - & yes & - & - & - & - & 1 & 22 \\
\hline TR 1A & 2 & 7 & 22 & - & yes & - & - & - & - & 3 & 32 \\
\hline TR 1B & 1 & 3 & 40 & - & yes & - & - & - & - & 4 & 47 \\
\hline Totals & - & 598 & 1553 & 27 & - & 25 & 21 & 6 & 4 & 31 & 2,265 \\
\hline
\end{tabular}




\section{Appendix H}

\section{Occurrences of Time Period Diagnostics}

(Mixing of Artifacts)

David L. Nickels

This appendix provides, in table format, a chronological synthesis of the datable artifact assemblage. The broad categories of chipped stone, buttons, bottle glass, ceramics, stoneware, porcelain, metal, and glass were used to determine the approximate ages of the artifacts recovered from the ninety-five different excavatioin levels. Chipped stone was presumed to be prehistoric in age. The following legend applies to Appendix $\mathrm{H}$ :

$$
\begin{gathered}
\text { Bu }=\text { Buttons } \\
\mathbf{C}=\text { Ceramics } \\
\mathbf{G}=\text { Bottle Glass }
\end{gathered}
$$

$M=$ Metal (including nails, bolts, and screws)

$\mathbf{O}=$ Other (e.g., plastic, rubber, etc.)

$\mathbf{P}=$ Porcelain

$\mathbf{S}=$ Stoneware 
Appendix H

\section{Occurrences of Time Period Diagnostics}

(continued)

(Mixing of Artifacts)

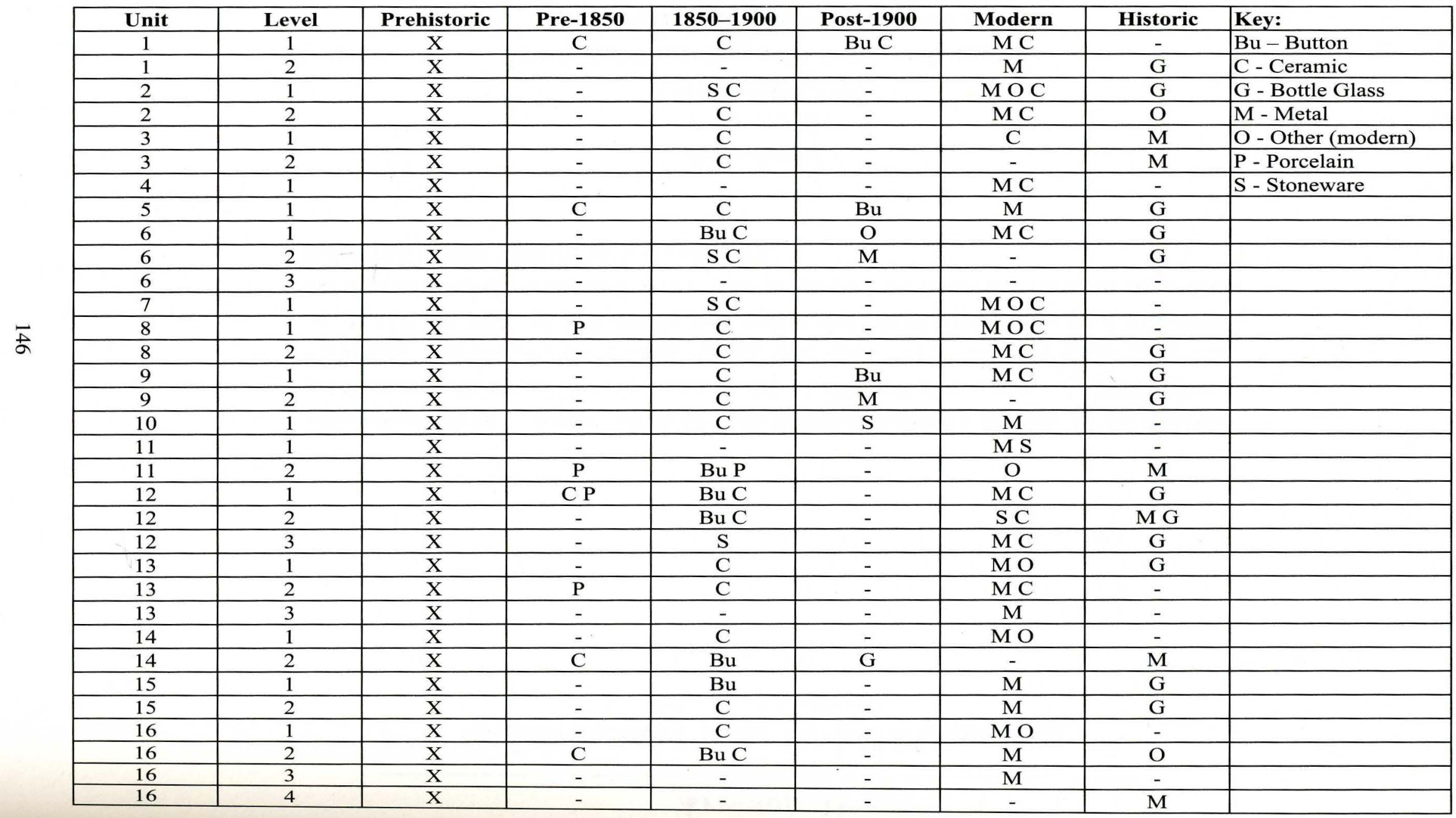




\section{Appendix H}

\section{Occurrences of Time Period Diagnostics}

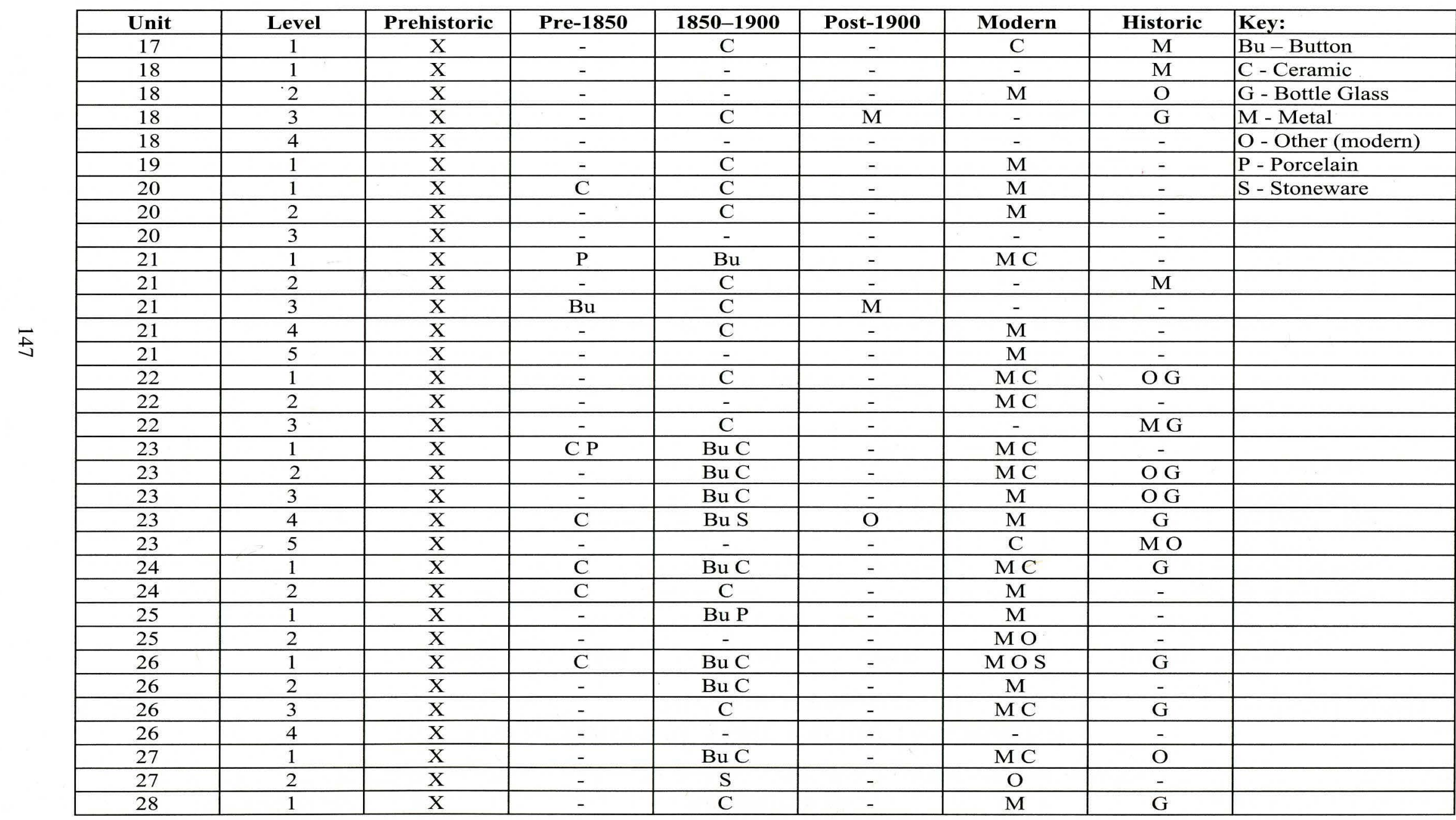


Appendix H

\section{Occurrences of Time Period Diagnostics}

(continued)

(Mixing of Artifacts)

David L. Nickels

\begin{tabular}{|c|c|c|c|c|c|c|c|c|}
\hline Unit & Level & Prehistoric & Pre-1850 & $1850-1900$ & Post-1900 & Modern & Historic & Key: \\
\hline 29 & 1 & $\mathrm{X}$ & - & - & $\mathrm{M}$ & - & - & $\mathrm{Bu}-$ Button \\
\hline 29 & 2 & $\mathrm{X}$ & - & - & - & $\mathrm{M}$ & - & C - Ceramic \\
\hline 30 & 1 & $\mathrm{X}$ & - & $\mathrm{C}$ & - & $\mathrm{M}$ & - & G - Bottle Glass \\
\hline 30 & 2 & $\mathrm{X}$ & - & $\mathrm{Bu} \mathrm{C}$ & - & $\mathrm{MC}$ & - & M - Metal \\
\hline 30 & 3 & $\mathrm{X}$ & - & $\mathrm{C}$ & - & $\mathrm{M}$ & - & O - Other (modern) \\
\hline Feature 4 & Holes & $\mathrm{X}$ & - & - & - & - & - & P - Porcelain \\
\hline Feature 4 & Level 1 & $\mathrm{X}$ & - & - & - & - & $\mathrm{M}$ & S - Stoneware \\
\hline Feature 4 & Level 2 & $\mathrm{X}$ & - & - & - & - & $\mathrm{M}$ & \\
\hline Feature 4 & Surface & $\mathrm{X}$ & - & $\mathrm{Bu}$ & - & $\mathrm{M}$ & - & \\
\hline Site & Surface & $\mathrm{X}$ & - & - & - & - & - & \\
\hline ST 1 & 1 & $X$ & - & - & - & - & $\mathrm{O}$ & \\
\hline ST 1 & 2 & $\mathrm{X}$ & - & - & - & - & $\mathrm{M}$ & \\
\hline ST 10 & 1 & $X$ & - & - & - & - & - & \\
\hline ST 11 & 1 & $X$ & - & - & - & - & - & \\
\hline ST 12 & 1 & $X$ & - & - & - & - & - & \\
\hline ST 12 & 2 & $X$ & - & - & - & $\mathrm{M}$ & - & \\
\hline ST 2 & 1 & $\mathrm{X}$ & - & - & - & $\mathrm{M}$ & - & \\
\hline ST 3 & 1 & $\mathrm{X}$ & - & - & - & - & - & \\
\hline ST 3 & 2 & $X$ & - & - & - & - & - & \\
\hline ST 4 & 1 & $X$ & - & - & - & $\mathrm{M}$ & - & \\
\hline ST 5 & 1 & $X$ & - & - & - & $\mathrm{M}$ & - & \\
\hline ST 6 & 1 & $\mathrm{X}$ & - & - & - & - & $\mathrm{M}$ & \\
\hline ST 6 & 2 & $X$ & - & - & - & - & $\mathrm{M}$ & \\
\hline ST 7 & 1 & $X$ & - & - & - & - & $\mathrm{M}$ & \\
\hline ST 8 & 1 & $\mathrm{X}$ & - & - & - & $\mathrm{M}$ & - & \\
\hline ST 9 & 1 & $X$ & - & - & - & - & - & \\
\hline TR 1A & 1 & $X$ & - & $\mathrm{Bu}$ & - & $M$ & $\mathrm{G}$ & \\
\hline TR 1A & 2 & $\mathrm{X}$ & - & - & - & $M$ & - & \\
\hline TR 1B & 1 & $X$ & - & - & $\mathrm{Bu}$ & $\mathrm{M}$ & $\mathrm{G}$ & \\
\hline
\end{tabular}




\section{Appendix I}

\section{Fauna}

Barbara A. Meissner

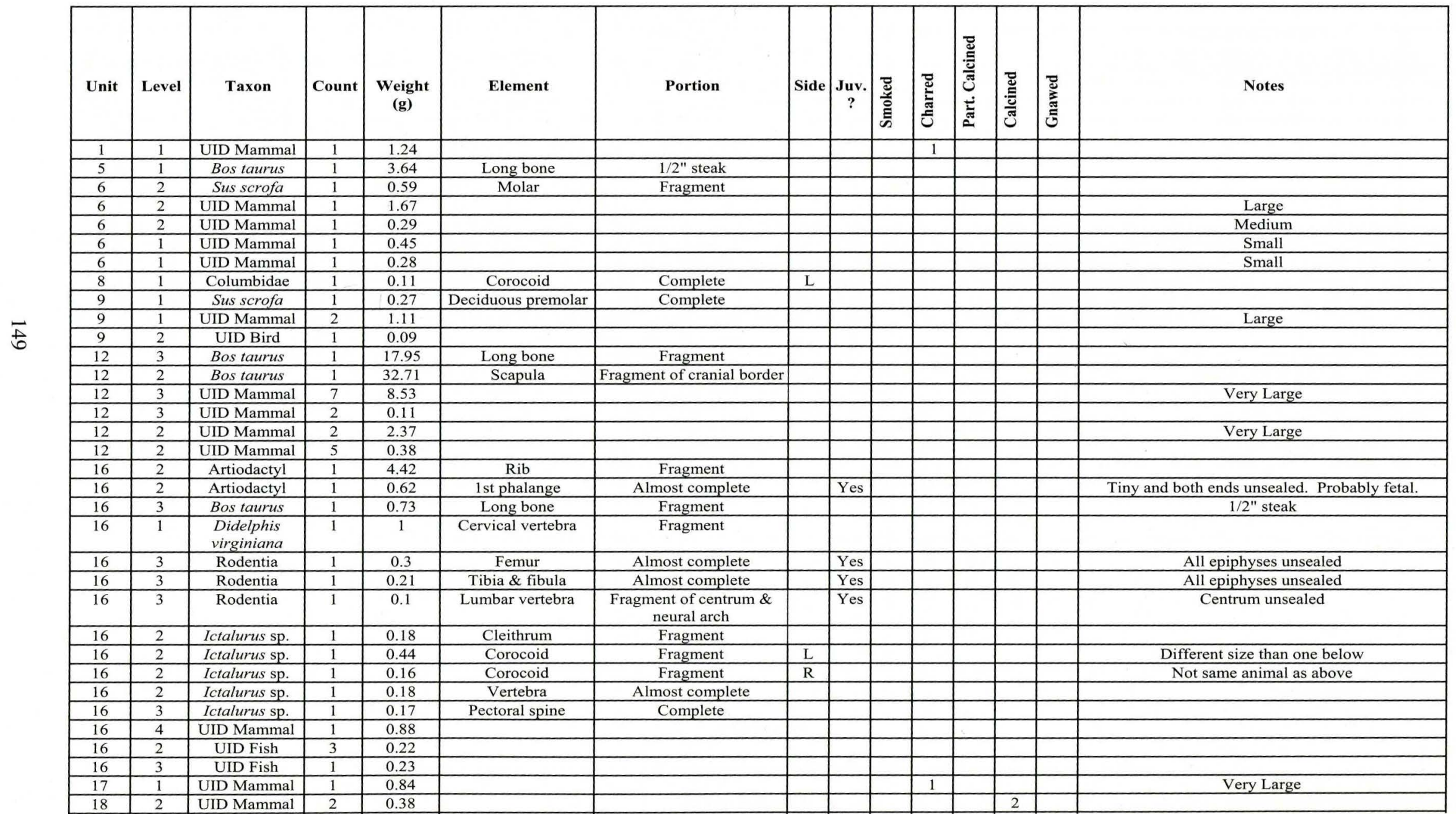




\section{Appendix I}

\section{Fauna}

(continued)

Barbara A. Meissner

\begin{tabular}{|c|c|c|c|c|c|c|c|c|c|c|c|c|c|c|}
\hline Unit & Level & Taxon & Count & $\begin{array}{c}\text { Weight } \\
\text { (g) }\end{array}$ & Element & Portion & Side & Juv. & 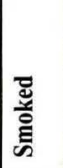 & 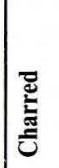 & 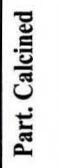 & $\frac{\bar{\Xi}}{\frac{\vec{E}}{\tilde{E}}}$ & | & Notes \\
\hline 20 & 2 & Sus scrofa & 1 & 0.91 & Molar & Fragment & & & & - & & & & \\
\hline 21 & 3 & UID Mammal & 3 & 1.28 & & & & & & & & & & \\
\hline 23 & 5 & Sus scrofa & 1 & 1.49 & Molar & Fragment & & & & & & & & \\
\hline 23 & 3 & Ictalurus sp. & 1 & 0.18 & Vertebra & Centrum & & & & & & & & \\
\hline 23 & 4 & UID Mammal & 4 & 0.75 & & & & & & & & 1 & & \\
\hline 23 & 2 & UID Mammal & 5 & 2.56 & & & & & 1 & 1 & & 3 & & \\
\hline 23 & 3 & UID Mammal & 2 & 5.81 & & & & & & & & & & Large \\
\hline 23 & 3 & UID Mammal & 1 & 0.28 & & & & & & - & & & & \\
\hline 24 & 2 & UID Mammal & 5 & 38.54 & & & & & & & & & & Very Large \\
\hline 24 & 2 & UID Mammal & 66 & 8.71 & & & & & & & & & & \\
\hline 25 & 2 & $\begin{array}{c}\text { Lepus } \\
\text { californicus }\end{array}$ & 1 & 3.32 & Innominate & Almost complete & $\mathrm{R}$ & & & & & & & \\
\hline 25 & 2 & UID Mammal & 1 & 2.34 & & & & & & & & & & large \\
\hline 25 & 1 & UID Mammal & 1 & 0.53 & & & & & & & & & & Large \\
\hline 25 & 2 & UID Bird & 1 & 1.51 & & & & & & 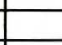 & & & 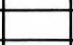 & \\
\hline 27 & 2 & Bos taurus & 1 & 8.41 & Innominate & 12 " chuck & & & & & & & & \\
\hline 27 & $\frac{2}{2}$ & Bovinae & 1 & $\begin{array}{l}0.41 \\
11.3 \\
\end{array}$ & 2nd phalange & 12 circen & & Yes & & & & & & Small, proximal end barely sealed \\
\hline 27 & 2 & $\begin{array}{c}\text { Sigmodon } \\
\text { hispidus }\end{array}$ & 1 & 0.67 & Cranium & Anterior $2 / 3 \mathrm{w} /$ incisors & & & & & & & & \\
\hline 27 & 2 & $\begin{array}{c}\text { Sigmodon } \\
\text { hispidus }\end{array}$ & 1 & 0.01 & Cheek tooth & Complete & & & & & & & & \\
\hline 27 & 2 & $\begin{array}{c}\text { Colinus } \\
\text { virginianus }\end{array}$ & 1 & 0.27 & Tarsometatarsus & Proximal 2/3 & $\mathrm{R}$ & & & & & & & \\
\hline 27 & 2 & Ictalurus sp. & 1 & 0.06 & Vertebra & Centrum & & & & & & & & \\
\hline 27 & $\frac{2}{2}$ & UID Bird & $\frac{1}{1}$ & 0.033 & vericonda & Ccintum & & & & & & & & \\
\hline 29 & 2 & Bos taurus & 1 & 9.83 & Rib & Fragment & & & & & & & Rod. & Heavily root damaged, lots of rodent chewing \\
\hline 29 & 2 & UID Mammal & 1 & 0.43 & Innominate & $\begin{array}{c}\text { Ischium and fragment of } \\
\text { acetabulum }\end{array}$ & $\mathrm{L}$ & & & & & & & $\begin{array}{l}\text { Small. Signs of extreme inflamation. Grossly } \\
\text { deformed and eroded. }\end{array}$ \\
\hline 30 & 2 & Sus scrofa & 1 & 2.65 & Deciduous premolar & $\begin{array}{c}\text { Fragment } \\
\end{array}$ & & & & & & & & \\
\hline 30 & 2 & UID Mammal & 2 & 0.82 & & & & & & & & & & \\
\hline Ftr. 4 & & Caprinae & 1 & 12.11 & Calcaneus & Almost complete & & & & & & & & Too eroded to ID \\
\hline Ftr. 4 & 1 & UID Mammal & 1 & 4.37 & & & & & & & & & & Very Large \\
\hline P. H. 1 & & UID Mammal & 1 & 1.26 & & & & & & & & & & Large \\
\hline ST 8 & 1 & Mammal & 1 & 0.16 & & & & & & 1 & & & & \\
\hline Tr. $1-\mathrm{A}$ & 1 & UID Mammal & 1 & 2.77 & & & & & & & 1 & & & Very Large \\
\hline Tr. 1-B & 1 & UID Mammal & 4 & 3.75 & & & & & & 1 & 1 & & & 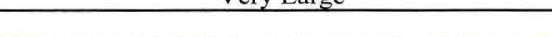 \\
\hline & & & $\# \#$ & 210.26 & & & & & & & & & & \\
\hline
\end{tabular}




\title{
APpendix J
}

\section{Transcript of Audiotape Interview with Isobel Gutierrez, Sr.}

\author{
Kevin Lane Schubert \\ Southwest Texas State University, San Marcos
}

Tape One: Side B

September 25, 2000

Monday, 1:00 p.m.

On September 9, 2000, at 1:00 p.m. an interview was conducted with Isobel Gutierrez, Sr. This individual is crucial for information dealing with the excavation and historical background of General Edward Burleson's cabin at Aquarena Springs (San Marcos Springs). He was one of the men who dismantled the original cabin and with the same logs, as well as other logs from two other locations, assembled a replica cabin south of the original location. The interview was held on the site (41HY37) where Mr. Gutierrez and I met to discuss the cabin. The interview begins facing north looking at the backside of the gondola building.

ISOBEL: Right on the other side of that tree.

KEVIN: Right on the other side of this tree, here in front of the gondola? (Northeast side of the gondola). $\mathrm{I}: Y e a h$, facing the road (the cabin) ... right where we got it here, except we moved it.

K: Moved it out towards the... towards the hillside a little bit? (Moved it south.)I: Yeah, some of this... wood you know, some of 'em was the ones that were there, some of it we tear it from somewhere else.

K: Okay.

I: You know.

K: Okay.

I: But, you can see the difference in the woods, see here.

$\mathrm{K}$ : Yes sir.

I: Some of 'em are about the same like that over there, and then you see these darker ones, that's the ones that were kinda bad.

$\mathrm{K}$ : So you did use some wood from the original cabin?

I: Oh yeah, use, yeah, we used a lot of it. We had it marked at the time, but I don't know if you can still see it or not.

$\mathrm{K}$ : Yeah, let's see if there is a mark inside.

I: Don't know if we should walk on these things.

K: I know, may fall in.

I: Yeah, we had some tags on it and marks.

$\mathrm{K}$ : And the marks indicated...? 
I: Yeah, the wood in which you ... the wood that came from here. See this wood here? A lot of it is from one side of the wall, except you see like here, here, that's different, that's different.

$\mathrm{K}$ : Okay, from this area here and here.

I: You see the difference, right here the same, all this, except, you see back there?

K: Yes.

I: Different.

$\mathrm{K}$ : Okay. This is going to be the, the... southwest corner of the ... of the cabin. Inside room 1, let's call it, is a ... the upper portion, about the fifth piece of wood up, from here up, is what is from the original cabin.

I: Yeah, the wood over here on top.

$\mathrm{K}$ : That's from the original cabin?

I: That's from original. Starting about 1, 2, 3, is not original.

$\mathrm{K}:$ These three are not original, but the other ones are original.

I: This one was brought from somewhere else.

$\mathrm{K}$ : Okay, so these three you brought from somewhere else.

I: Yeah, brought from somewhere else.

$\mathrm{K}$ : And the one on top.

I: I take it back, this one here. This one from original here. Except two of 'em, you can see right here.

$\mathrm{K}$ : These two here?

I: These two, you see the difference on how they, they made it.

$\mathrm{K}$ : Yes, I see that.

I: See this.

$\mathrm{K}$ : So, oh yeah. So these two here are going to be the original cabin.

I: The original, yeah, and uh, but this was ... all coming mostly out of that one.

$\mathrm{K}$ : Out of the original cabin.

I: We got some from different places.

$\mathrm{K}$ : And that was all just.... was it all just dilapidated and on the ground?

I: Yeah, they wanted to take the wood on the bottom, we put a different on. So they were all rotten.

$\mathrm{K}$ : Excellent, and ... let's go look in this other one here, in this cabin, in the other room, room 2 we'll call it.

I: It was right on the side of that tree (the cabin).

$\mathrm{K}$ : Right on the other side of this tree.

I: Right on... oh, I'd say maybe, from about the corner of that..., this tree wasn't here.

$\mathrm{K}: H m, H m$, right.

I: This tree come up later you know. But just about from there it was facing that way.

$\mathrm{K}$ : Facing this way?

I: Facing the road (Ed J. L. Green Drive).

$\mathrm{K}$ : And so it would be all underneath this concrete here (of the gondola).

I: All in here, yeah, and built exactly the same as it is there.

K: Okay.

I: Exactly. 
$\mathrm{K}$ : Exactly the same, exactly.

I: We didn't change anything.

K: Okay.

I: We left it as it was. The only thing is like I said.

$\mathrm{K}$ : I mean it was ... the cabin itself whenever you were up here, it was all falling down.

I: Yeah, that's the reason we tore it down.

$\mathrm{K}$ : Yes, exactly.

I: That's the reason we tore it down.

$\mathrm{K}$ : Okay, what year was the gondola built? Do you remember?

I: Let's see ... '60, Mr. Rogers died in '63, I think, and we built it about '59 or '60.

$\mathrm{K}$ : '59 or '60 the gondola was built (1959 or 1960)?

I: $U h$ huh.

$\mathrm{K}$ : And .... y'all tore down the cabin itself to build the gondola.

I: Yeah...no, we tore it down because of the kids.

$\mathrm{K}:$ Oh really.

I: They come through school.

K: Oh, okay.

I: And we was afraid something was gonna knock' 'em on their heads. That's the reason we tore it down.

$\mathrm{K}$ : Can you remember what year you tore the cabin down?

I: That was in '50... about around' 55.

$\mathrm{K}$ : Around '55 (1955) the cabin was torn down because of the students walking up the hill.

I: They started to go through there and the kids come and play. We were afraid that somebody gonna get one of those things on top of them.

$\mathrm{K}$ : Do you remember anything... an outset building, another building that was other than this, the original cabin?

I: Other than the original one?

$\mathrm{K}$ : Yeah.

I: It was just a little bitty one, but it was all rotten.

$\mathrm{K}$ : It was all rotten. Do you remember where that one was?

I: Well, let's see, that house, I'd say somewhere right along in here.

$\mathrm{K}$ : Right along in here, maybe where the memorial sign was.

I: Somewhere right along in here.

K: Okay.

I: Yeah, that's where it was.

K: Okay.

I: Now, that sign wasn't here (DRT monument).

K: Right. Exactly.

I: It was up here.

$\mathrm{K}:$ Oh, really.

I: Yeah.

$\mathrm{K}$ : The original, the original memorial sign was up in front of the house. 
I: Yeah, in front of this building (the gondola).

K: Okay.

I: Right in front of it, and there used to be a little road, that goes like this in a half moon.

$\mathrm{K}$ : In a half moon, and it came right past there (in front of the gondola).

$\mathrm{I}$ : And the house was right there (under the gondola).

$\mathrm{K}$ : And, what we, one thing that we did do was in excavation...., you can see the excavation units here, and, where we excavated we found certain stones laid out here. Now it didn't look like there was any kind of a trench, um, foundation trench... (Excavation units 25, 29, 27, and 16).

I: Nah, nah.

$\mathrm{K}$ : .... going around it, so this wasn't the original site.

I: No, no.

$\mathrm{K}$ : So these stones were brought from here.

I: Yeah, when we dug up here everything we just throw it up there.

$\mathrm{K}$ : Throwing it right in here (excavation units stated above).

I: Later on we just...

$\mathrm{K}$ : Started chunking it off the side over there.

I: Yeah, on the side of it, but we didn't take it out to use it for anything, we just took it out to make that hole for that weight.

$\mathrm{K}$ : Yes, Yes. So right in here, to put this concrete in that hole.

I: Yeah, those things are deep.

$\mathrm{K}$ : Exactly. So all the foundation stones were taken out of the cabin?

I: Everything.

$\mathrm{K}$ : Everything was taken off of the cabin?

$\mathrm{I}$ : Everything, even that chimney right there.

$\mathrm{K}$ : Even the chimney, and they were thrown off here and thrown over the edge, as well? (Edge of the south hillside behind the cabin.)

I: Yeah, we put it up here, the ones that came out of the chimney because we had to rebuild it back.

K: Oh, okay, right. Oh, okay.

I: We had to put it back like it was.

$\mathrm{K}$ : Exactly, exactly.

I: We took pictures of it, you know, how it looks like so we knew exactly how to put it back.

$\mathrm{K}$ : So you took pictures of the original cabin before you tore it down?

I: Yeah, uh huh, before we tore it down.

$\mathrm{K}$ : Excellent.

I: Then we started building it over here.

$\mathrm{K}$ : Do you know exactly, who maybe would have those pictures or where we could......?

I: I had some, but I don't know what I did with them.

$\mathrm{K}$ : Oh really, really, all right.

I: They might be at home, but I don't know.

$\mathrm{K}$ : Yeah, exactly.

I: Yeah, I just don't... remember where I put 'em. 
K: Okay.

I: But I might have 'em. If I have it, I'd be glad to show it to you.

$\mathrm{K}$ : Oh, I would appreciate it if you did find these. That would be extremely beneficial for us.

I: Yeah.

$\mathrm{K}$ : Let's walk over here. I have another question here. I'm gonna stop this... (Break in recording).

K: So there was a fence probably 10 feet away from the replica cabin? (On the north side).

I: Yeah.

$\mathrm{K}$ : To the north.

I: It used to be right here.

$\mathrm{K}$ : And it went all the way across the .... parallel to the cabin?

I: They were like cedar posts.

K: Okay, cedar post fence.

I: With a fence on it. But we tore it down to put a cyclone fence so the kids won't come from the Sky Ride.

$\mathrm{K}$ : Into here, yeah.

I: Yeah, 'cause we hadn't built completely everything.

$\mathrm{K}$ : Exactly, so did y'all use the same foundation rocks to build this foundation as well?

$\mathrm{I}:$ Yeah, everything.

$\mathrm{K}$ : All right, see this bedrock here, how it comes out. This looks like it comes into corner, was this like that? (Bedrock in excavation units 4 and 10).

I: Yeah.

$\mathrm{K}$ : It was just like this, so this was just exposed bedrock is what that was.

I: Yeah, that's all. Rain you know, it just cover it all.

$\mathrm{K}$ : This mound here, this mound (steep slope running north up to the gondola building).

I: The same thing.

$\mathrm{K}$ : It's built up?

I: No.

$\mathrm{K}:$ No, that was just like that?

I: Just the way it was cause the house was up there.

$\mathrm{K}$ : Okay. So this was just a ledge, a natural ledge, that ....okay.

I: And this was all the same, like here. But they had, like I said, a cedar fence here and then later on we put in a cyclone fence, 'cause the kids, you know, they come out and start playing over here and we didn't want them to get hurt, so we put another one up so the people would have to come in from down there.

$\mathrm{K}$ : To get in to see the replica.

I: Yeah.

$\mathrm{K}:$ Okay, so there was a fence that went all the way along here.

I: But they had one of their own here, but I don't know what they had along here, probably for the backside.

K: Backside of the house, exactly. Do you remember if there was a house or any kind of structure that was...? (Pointing east across the current fence that runs north and south).

I: Nothing. 
$\mathrm{K}$ : Nothing was down there?

I: Nothing.

$\mathrm{K}$ : I noticed whenever I was walking around, I noticed a spigot, a water spigot down there.

I: No, we put it there.

$\mathrm{K}:$ Oh, y'all put a water spigot in.

I: Yeah, we put that in there, 'cause we was gonna clear all this up and put some plants all over there.

$\mathrm{K}$ : Okay, and never did.

I: He passed away and once he passed, everything went.

$\mathrm{K}$ : Everything went up, huh?

I: Yeah.

$\mathrm{K}$ : Well, let's walk around here.

I: Yeah, that's the reason we stopped that. But you see all these rocks?

$\mathrm{K}$ : All this is from the foundation and a lot of these are from the original chimney.

I: Oh yeah, they come from there.

K: Okay.

I: We just built it back.

$\mathrm{K}$ : This was the old radio tower, is that what that was? (Round cement block directly east of the chimney).

I: That's where the... well, some kind of a tower that they put in here.

K: Yeah.

I: And, the dumb thing fell off.

$\mathrm{K}$ : Yeah, that's what we heard, that it fell off, it fell down.

I: Yeah, it was way up there.

$\mathrm{K}$ : And y'all put this retaining wall in there?

I: Yeah, we put that in there, so you know this thing was pointing like this.

$\mathrm{K}$ : It was straight down, just a straight slope? (To the south)

I: Uh huh.

$\mathrm{K}$ : Now over here we found a feature that we can't make much sense out of, we have some...

I: Where you want to go?

$\mathrm{K}$ : Right to here.

I: Oh, oh, okay.

$\mathrm{K}$ : And,we can't make much sense of it, but maybe you could shed some light on it for us. What we found here is a feature that has these niches in the rock itself and uh... (Bedrock feature 4)

I: That's the way it was.

$\mathrm{K}:$ This is the way it was. It looked like this before?

I: Yeah, we didn't do anything to it.

$\mathrm{K}$ : Okay. This is an original feature then.

I: Yeah. What it was, I don't know.

$\mathrm{K}$ : Yes, exactly.

I: But I mean that's...

$\mathrm{K}$ : How it looked, and you remember this? 
I: We found it when we cleared and you know, and that's the reason we put that rock fence in here so people wouldn't come walking up and hurting themselves.

$\mathrm{K}$ : Hurting themselves up in this region here.

I: Yeah, uh huh, but we left it like it was.

K: Okay.

I: I said no, no, no, just leave it like that. Ol' Green wanted to put some plants and I said no.

K: Oh really.

I: I said you put some plants in that thing and people gonna start coming down in here and people get hurt and take pictures and stand up there.

$\mathrm{K}$ : And there used to be a petting zoo here. Is that correct?

I: Yeah. That was way up on the hill.

$\mathrm{K}:$ Oh, that was way over there? That wasn't here?

I: No, no, no.

$\mathrm{K}$ : That wasn't here anywhere?

I: No, that was down below.

$\mathrm{K}$ : Let's walk this way, I think it's a little bit easier than going up that way.

I: I used to walk around on this thing, but once you get old it's not too easy. I am 77 years old.

$\mathrm{K}$ : What years did you work here at Aquarena Springs?

I: I worked 37 years, a little over 37.

$\mathrm{K}$ : Do you remember the dates of that?

I: Yeah, I started in February '53 (1953).

K: February '53.

I: February 2, '53.

K: February 2, '53. Okay, and 37 years after?

I: Well, just about. I retired in November of ' 90.

K: Of ' 90 ?

I: Yeah,1990. It got to be over 10 years.

$\mathrm{K}$ : Yeah, that's good, and you said this monument here, this stone, it was in the original. Let's walk up there and see what... Yeah, up in front and see what it looks like.

I: Yeah, it was right in front of his house, that is where they put it. They put it up in front.

$\mathrm{K}$ : Well, you know that's what we thought .... was that, that the original site was underneath this building, this gondola building.

I: Yeah, right there, uh huh, right there, that's where it was.

$\mathrm{K}$ : So, everything was taken out, foundation stones and everything.

I: Yeah, uh huh. Ol' Burleson was about, oh, that house is up there. Ol' Burleson was right in there (talking about the DRT monument sign and pointing at the fence around the gondola on the north side close to Ed J. L. Green Drive).

$\mathrm{K}$ : Right in this area here?

I: Uh huh, right in this area. And the house was right just behind it, but this was put on later, you know, by the people.

$\mathrm{K}$ : Oh, wait. Wait, what was that? 
I: Somebody else, whether the city or those uh...

$\mathrm{K}$ : What, put the house in there?

I: No, no.

$\mathrm{K}:$ Oh, the monument.

I: Yeah.

$\mathrm{K}$ : And the monument sat right here?

I: Yeah, it sat right here.

$\mathrm{K}$ : Right in here, and the house that Burleson built?

I: Was about right here (pointing underneath the gondola).

$\mathrm{K}$ : Right there.

I: Before the house was here, no monument here.

K: Yeah.

I: The road used to come right in here.

$\mathrm{K}$ : Yeah, right in here. Okay, inside the fence next to the gondola.

I: Then they moved it up.

$\mathrm{K}$ : Do you remember anything ... any kind of structure out on top of this hill? (Hill directly north of Ed J. L. Green Drive).

I: On top of this hill, just houses, but it was nothing back then.

$\mathrm{K}$ : Nothing then.

I: No, no, no.

$\mathrm{K}$ : Now, do you remember the cabin itself was pretty much blown by a hard wind in the early 1900s?

I: The only thing that was bad was right here (front north side of house), and that wall right there (west wall of cabin).

$\mathrm{K}:$ Okay, on the right side.

I: Yeah.

$\mathrm{K}:$ Oh, and just one wall was pretty much remaining (east wall of cabin).

I: Yeah, and you had the other three walls, but some of them logs was beginning to slip out, you know, and he was afraid that somebody was going to get in there and get one of those...

$\mathrm{K}$ : And so there was a second building and that was on this side? (East side of cabin).

$\mathrm{I}$ : Yeah, that was a little one. I don't know what it was for.

$\mathrm{K}$ : Probably some kind of um...

I: Storage.

$\mathrm{K}$ : Storage or some building like that.

I: It was about, um, eight by uh, about eight by eight.

K: Eight by eight? (Feet).

I: Yeah, it was about..... see the house was end up about right here (east wall of the gondola building), and that little building was right...

$\mathrm{K}$ : Right in this area here?

I: Yeah, right in there (east of the east wall of the gondola building approximately 10 feet away).

$\mathrm{K}$ : And that was pretty much... and y'all tore that down?

I: That one was already.... 
$\mathrm{K}$ : And that one was already dilapidated and falling down?

I: Yeah, it was about that wide.

K: Okay, yeah.

I: It was seven, eight feet and uh, but the whole thing was all gone. But this wall was not too bad (east wall of cabin).

$\mathrm{K}$ : Oh really, this wall in the house, the north wall would have been ... (north wall was not together). I: It was one of those... logs were beginning to slip. Some of them sticking out. Paul there said, get those things out of there.

$\mathrm{K}$ : Was that Paul Rogers?

I: Yeah, the owner.

K: The owner, Paul Rogers, told you to go ahead and take it out?

I: He said, no, just go ahead and take it out else someone gonna get hurt. So I came up with some men and knocked it down.

$\mathrm{K}$ : All right.

I: And.... but he told me to mark everything and save it. Put it up there.

$\mathrm{K}$ : Do you remember what markings there were?

I: We put some tags and then we put some of that....not that permanent marker but something that we could erase.

$\mathrm{K}$ : Okay, some kinda...

I: Yeah, it was markers but you could erase it.

$\mathrm{K}$ : Oh, okay. But there were tags on it at one time.

I: Oh yeah. We tag it like number 1 and so on, you know. Either from the top or bottom, but we tagged everything.

$\mathrm{K}$ : So, this original wall here, that was kinda still standing? (East wall).

I: Yeah, but like I said, it was beginning to slip. The logs.

$\mathrm{K}$ : Uh huh, the logs were beginning to slip and they were on... That would have been the....chimney would have been on this side (east wall of the cabin).

I: Yeah, on that side.

$\mathrm{K}$ : On this side here. Okay.

I: Well, it turned a little bit.

$\mathrm{K}$ : Yeah, it turned a little bit, this way to the right.

$\mathrm{I}$ : The thing was facing the...

$\mathrm{K}$ : The chimney was facing that way more?

I: More about to the east, but we built it exactly back like it was.

$\mathrm{K}$ : Excellent.

I: Exactly like it was. We didn't change nothing.

K: Good, good.

I: And he didn't want nothing to be changed. He said we'll mark everything and put it separately.

$\mathrm{K}$ : Right.

I: Like this wall, we put it in one pile, this wall, and that's where we put the old ones, you know, in there.

K: Really. 
I: Not old ones, but uh, like they got on that side, you know.

$\mathrm{K}$ : They got some of the wood from a stagecoach outside of town?

I: No, we get it over here in town. You know where Goodyear is? Right there.

$\mathrm{K}$ : Right there, you're right, that used to be an old stage coach which...

I: Well, one was a log cabin in the back.

K: Oh, O.K.

I: I didn't even know it was there until we went and looked at it.

$\mathrm{K}$ : Let's walk into that other, walk around this way, into that other room there. I think there are a couple of questions in there I may have, and let's see, this is interesting, this is good.

I: Yeah, we put a lot of work in this thing.

$\mathrm{K}$ : Yeah, it seems like it.

I: A lot of work into it.

$\mathrm{K}$ : This was originally here, this here drop off? (East slope off of the gondola building).

I: Yeah, everything, cause they built this up. Like up in here, the dirt pile that we got out of that, we piled it up here.

$\mathrm{K}$ : Oh okay, so this was a little bit modified?

I: Yeah, this was more sloped from about, oh, about this here.

$\mathrm{K}$ : And it sloped more down that way. Okay.

I: And then he said, well, it cost too much to throw this out, so just throw it down.

$\mathrm{K}$ : So a lot of it was thrown out in this area here? (Lumber from the cabin was thrown down the slope off of the northeast side of the original site of the cabin).

I: Yeah, we just throw it out.

$\mathrm{K}:$ To the northeast of the site.

I: Yeah, there was no, no nothing in there. All he had was cows.

K: Oh really. Do you remember, also, maybe off of the house a little, uh, sort of a horse corral maybe where they stored their horses, or anything like that?

I: No, that I didn't see, probably was all...

K: Yeah, probably dilapidated, I'm sure, before.

I: Yeah, but it was, the only thing was that little room, but it was all just about in piles. It was gone.

$\mathrm{K}$ : It was completely gone too, huh?

I: Yeah.

$\mathrm{K}$ : All right, this is good. This is real good.

I: From about right here, that's where they start throwing them.

$\mathrm{K}$ : Oh really, from about there. And that used to be just a gradual slope?

I: Yeah, just a gradual slope. But uh, the one we couldn't figure is that over there on the bottom, the rock.

$\mathrm{K}:$ Oh really.

I: I couldn't figure it out. Nobody could figure it out.

$\mathrm{K}$ : Which one was that?

I: The one that got those holes. You know, the one on the bottom on the other side.

$\mathrm{K}$ : The steps? 
I: No, no. The one that got those little holes going in.

K: Oh yeah, the bedrock, yeah. We couldn't figure that out either (bedrock feature 4). Well, this here.

I: This wall here is all exactly like it was (west wall of room 2 adjoining the dog run).

$\mathrm{K}:$ Really? Okay, okay.

I: We didn't change anything, even the ...

$\mathrm{K}$ : Even the door.

I: Even the door.

$\mathrm{K}$ : This door is ...

I: Yeah, it was right there.

$\mathrm{K}:$ Oh, okay.

I: This thing was covered with one-by's in parts.

K: Really.

I: Uh huh, and we took it off and we make the doors.

$\mathrm{K}:$ Oh, okay, and this dog run here, this was all covered in?

I: No, no. It was open.

$\mathrm{K}$ : It was open in there?

I: Uh huh, it was open. The only thing we changed was the floor.

K: Right, okay. This stove here. Do you remember where y'all got that?

I: We got this one from Fredericksburg.

K: From Fredericksburg?

I: Yeah. This one was from Fredericksburg. We had everything that went with it. Where's the top, that one?

$\mathrm{K}$ : Yeah, I think that's the top right there.

I: Yeah, this all came from there, a lot of this wood. You can see the difference here. See right there, those two in that side over there (east wall of room 2 on the left side if facing the fireplace inside the room).

$\mathrm{K}$ : In that side over there?

I: Yeah, they're different. Now you look at this, this is different. All this from here except that one, that one comes with that part. But since we could fit 'em in there between the chimney, we put it right there.

$\mathrm{K}$ : Okay. So this is the original wood from this original side of the cabin?

I: Yeah, all of this right here, you could see how. Look at the difference.

K: Yeah.

I: And look at the difference there.

$\mathrm{K}:$ Oh exactly, exactly.

I: This one here, it was beginning to, it was already a little bad when we put it, but he said no, no. I want the originals. So we put it in and later on it began to deteriorate.

K: Exactly.

I: But those there, except that one right there, didn't come out of here. But you can see here we couldn't find anything that could reach like, the like, the big ones had. So we just build it in out of the little ones. But this part and all that part in there, all that part comes in there. Some of those we mixed from different places. 


\section{K: From the different places.}

I: But like this part here, it's all the same except that one right there.

$\mathrm{K}$ : Uh huh. That would be the third down on the left side of the second room (east wall).

I: The rest of them are the originals, and.... but like I said, you can tell some of this rock are new part (upper portion of the fireplace).

$\mathrm{K}:$ Yeah, this looks a lot newer here.

I: Yeah, this all... we got it from Wimberley. All this rock on the chimney here except the outside.

$\mathrm{K}$ : Now on the old ... these metal parts in here, now was this original? (Metal pieces inside the fire box of the fireplace).

I: That's original.

$\mathrm{K}$ : This is original from Burleson's cabin then?

I: Yeah, uh huh.

$\mathrm{K}$ : This piece here?

I: We just put it right back.

$\mathrm{K}$ : That is on the....

I: We put those hooks because we thought it was a door or something go in there.

$\mathrm{K}$ : This was in the original?

I: That the way they were.

$\mathrm{K}$ : Okay. So this is, the metal parts in the fireplace are the original pieces within the Burleson cabin.

I: It should have been another one somewhere in here, 'cause there was two of 'em.

$\mathrm{K}$ : Probably right in here, there's a hole, and here's a hole there.

I: Well, I know there was some more in there.

$\mathrm{K}$ : Yeah, okay, good.

I: But probably they just rot and went out, but I know there was some more here.

$\mathrm{K}$ : Excellent.

I: But they all come from the same chimney. But the only thing we put in was this part (upper portion of the fireplace).

$\mathrm{K}:$ Is this part and that part up there....

I: But the outside is ...

$\mathrm{K}$ : Everything is the same.

I: Is the same thing.

$\mathrm{K}$ : Well, wonderful.

I: We put wire in here for, you know.

$\mathrm{K}$ : Yeah, for electrical outlet and stuff like that.

I: For lights for people to see. Everybody want to come in here. Only thing we change was the floors, but if you see the bottom, we put these two.

$\mathrm{K}$ : So the cedar posts from here are all original except those three there. Okay (the three cedar posts in the dog run beginning from the south end moving north).

I: Yeah, we change it, we change it.

K: So these cedar posts here underneath this floor are all original. That's in the dog run to the northeast.

I: Right here, we put new ones here. They were cedar, but .... 
$\mathrm{K}$ : All on the porch were new.

I: You can see from where we put this here.

K: Yeah, okay.

I: But everything in between was same wood.

$\mathrm{K}$ : That's the same wood came from the Burleson cabin.

I: 'Cause we took pictures of it. And we wanted to build it exactly the same way it was. So we put 'em back.

$\mathrm{K}$ : So you may have some of these pictures at home, you say?

I: I might have some.

$\mathrm{K}$ : Wow, that would be, that would be...

I: The only one who got a lot of 'em, but he's dead.

$\mathrm{K}$ : Oh really, he's gone, huh? He had most of the pictures and what's his name?

I: He had, Willie Green.

K: Willie Green.

$\mathrm{I}:$ He used to live in Austin.

$\mathrm{K}:$ Oh, really.

I: But I think his wife disposed of 'em already.

$\mathrm{K}$ : Oh, really. So those pictures may be long gone.

I: Oh yeah, well, no tellin, '... may have it, his son or daughter may have it. But you can check with.... I don't know if they still got anything on his family, Willie Green ... but... he's the one who took the pictures and I take some, too, but not many. Where do you want to go?

$\mathrm{K}$ : Do you remember any buildings up in this area here?

I: Up there where the well is? (Heading west up the hill towards the replica mission at Aquarena springs).

$\mathrm{K}$ : Is that the original well?

I: Well, was, we rebuilt it exactly the way it was.

$\mathrm{K}$ : Exactly like it was, and that was where the original well was?

I: That's the original right there.

$\mathrm{K}$ : Right there.

I: We rebuild, too, you know.

$\mathrm{K}$ : To show what it looked like then.

I: What it was, the way it was.

$\mathrm{K}$ : But it looked pretty much like this?

I: Yeah. That's the way that they, Mr. Rogers had the pictures with. You know they had this big stone, this stone I don't know. We got it from Centerpoint (large stone on top of the well).

$\mathrm{K}$ : Where's that?

I: Centerpoint, right there next to Kerrville.

$\mathrm{K}:$ Oh, okay.

I: Right in there, back up in there.

$\mathrm{K}$ : So this stone comes from Centerpoint.

I: Yeah, uh huh, but this is the way it was. I mean, they built it by... it was to chisel it out. 
$\mathrm{K}$ : So the original stone that was here ...

I: The original, there was just rock.

$\mathrm{K}$ : Oh, O.K. So the original was taken off at a later point.

I: Yeah, they didn't have it like this, they only had rock like this.

$\mathrm{K}$ : Was there any kind of building around the well or anything like that?

I: Nah, nothing. It was only a little trail.

$\mathrm{K}$ : That went from there to there.

I: Yeah, that coming right through here and, uh, that was it.

$\mathrm{K}$ : That was it, pretty much. Well, excellent.

I: That's where it's coming from. That's where they get the water. 'Cause I asked Mr. Rogers where they get the water, 'cause everything here was brush, and he said come here, I'll show you.

$\mathrm{K}:$ Oh yeah, and he took you there?

I: Yeah, get somebody to cut this stuff off so we walked up here.

$\mathrm{K}$ : And this was just a little dirt trail that went from the well to the house, house to the well?

I: Yeah, that's all.

K: Okay.

I: But it was an old well back in there. That's where I asked him where did they get the water from.

$\mathrm{K}$ : Yeah, they need water way up here.

I: Yeah, they got to get water up here somewhere.

K: Exactly.

I: Without water they can't make it.

K: Exactly.

I: He said no, no, no, it's right here.

$\mathrm{K}$ : Excellent.

I: I want you to build me one. You'll have to use the rock they had. Get you some of that.

$\mathrm{K}$ : Well, good. Well, thank you very much, Mr. Gutierrez.

I: Sure.

$\mathrm{K}$ : I do appreciate that and ... we'll make contact to see if you have those pictures a little bit later on.

I: I might, like I said, I had some. Willie, he had more time than I did.

$\mathrm{K}$ : Exactly.

I: 'Cause he was in charge of the gardeners.

$\mathrm{K}:$ Oh, okay.

I: And he always taking pictures. One thing is he had a camera all the time.

$\mathrm{K}:$ Oh, really.

I: Oh yeah, all the time.

$\mathrm{K}$ : And that's Willie Green, okay.

I: Yeah, he used to be from Austin, but I don't know if his daughter still live up there or what. Might still have records here from then.

$\mathrm{K}$ : Yeah, we looked here, doesn't look like, they don't have any.

I.: They don't have any? 
K: They don't have any pictures from here. End of interview. 


\title{
Appendix K
}

\section{Reminiscence \\ by \\ Mrs. Vergie Richardson}

\author{
Manuscript submitted by: Boots Dunn \\ San Marcos, Texas \\ July 24, 2000
} "This is my aunt - she was a great-great-granddaughter of General Edward Burleson. She
graduated from Texas State Teacher's College (about 1932) which is now SWT." 


\section{Preface}

We are extremely fortunate to be studying the history of Texas while some of those men and women who grew up with Texas are still living. In this paper, I have written the remembrances of my grandmother, Mrs. Sarah M. Owen. Her grandfather and grandmother, whom she mentions in her reminiscence, were General Edward Burleson and his wife. She is their oldest living descendent.

The citations in my paper are merely sources from which general information, concerning the topic being discussed, may be found. 


\title{
Reminiscence
}

by

\author{
Mrs. Vergie Richardson
}

With a distinct feeling of inadequacy, I sat down beside my grandmother to ask questions concerning her remembrance of days gone by. There were many things I wished to hear about, but memory back through the years is no cut and dried affair; rather, it is the slow accumulation of events as one reminds us of another. I held my peace and waited for her to journey back through her store of memories. At length she began.

"I was born at Grandfather Burleson's old home at the head of the San Marcos River on November 14,1855 . When I was a little over a year old, we moved to a big farm near Bastrop where my father was the overseer of a big bunch of negroes. From there we moved to Blanco, then to Purgatory Springs (now Hugo) about twelve miles west of San Marcos. I remember one thing in particular that happened there. Late one afternoon, Grandmother Burleson came driving up in her buggy; with her was Old Jane, a negro slave. Grandmother informed my father that she had come to trade with him. It seemed that she wanted to sell Jane and wanted my father to take her because he owned Oll, Jane's husband. Father bought Jane for something over two thousand dollars in Confederate money.

Not so long after we went to Purgatory Springs, my father went to the Civil War. I do not remember his going, but I do remember that I thought he would never come back. He moved us down to stay with Grandmother Burleson while he was gone. He told Old Oll that he was leaving him to care for us until he came back, and that old negro really did his part." Here she paused. I was especially anxious to know about her stay with her grandmother during the war, and when I mentioned it, she continued, "Law, child, it seems as if I remember that time better than I do things that happened later."

They put me in school at the old Coronal Institute and left me in town to board with a Mrs. Driscoll. There were four rooms in the school at that time, I believe. Mr. Hollingsworth was the principal, but Mr. McBride taught me. We had the old Blue Book Speller and McGuffy's Reader. I was so proud when we got to the two syllable words, and, when I learned to spell 'baker,' I almost burst with pride. Aside from the seriousness of our studies, some funny happenings took place. A cistern was being put in behind the school. None of us knew there was to be any blasting; so, when a blast was set off and the rocks began to hit the tin roof, it scared all of us almost to death. Some children ran out the door, others jumped out the windows, and Mr. McBride was half way down the hill when the rocks quit hitting the roof.

On weekends, I went to Grandmother's house. She always had a job for me. One task left for me to do every Saturday was the making of candles from beef tallow. I used a mold that made twelve at a time. Every Saturday, I made enough to last until the next Saturday. Another job I had was the gathering of algerita roots, live oak bark and a certain kind of weed out of which dye was made. This weed was terribly hard to find, but Grandmother liked the beautiful brown dye it made. Another job I had was that 
of helping Old Jane with the family spinning. There were two threads to be spun, the coarse and the fine ${ }^{1}$. Jane spun the fine thread and I the coarse. When the thread was finished, we looped it across the back of a chair, tied it around the middle, making it into a hank, and then dyed it. Most of the thread, at that time, was taken to Granny Jewel, here in San Marcos, and she wove it into cloth for a certain amount a yard. We had few dresses in those days. I remember one I had," Grandmother chuckled as she remembered, "but that's about something else you will want to know about the Indians." I was interested in knowing just what connections they had with the Indians at that time, so I listened with doubled interest as she went on.

"I had a pretty white and brown checked dress. That dress was a real treasure to me, for it was the first new one I had had in a long time. When I washed it, it drew up terribly and I had to give it away, to an Indian girl, as it happened. A bunch of friendly Indians came by Grandmother's one day. With them were the squaw and three children of Old Placido who always felt privileged to come into our kitchen and eat what they wanted, for Placido had helped Grandfather in driving out the Indians. I can see Jane now busying herself setting up everything she did not want them to eat. I gave my dress to Placido's girl and my mother gave a pair of trousers to one of his boys; these boys were named Joe and Crock for my father and one of his brothers, Crockett. To our astonishment, the boy walked up to the house, some time later, wearing the trousers we had given him, but they were hardly to be recognized as trousers. He had ripped open every seam and then had tied strings over the trousers just below and just above each knee. Indians could not wear clothes when they had them.

The father of these boys, as I said, was Placido, a Tonkawa chief that Grandfather took with him in Indian battles ${ }^{2}$ and in trailing Indian raiders. It seems to me that he was buried by Grandfather in Austin. Then, too, I believe that their pictures were hung together in the old capitol at Austin. When it burned in 1881, the pictures were destroyed and Placido's could not be replaced. I remember hearing Grandmother tell about one time when Grandfather and Placido went after some Indians who had stolen some horses. After they were gone, Grandmother fixed a long pallet on the front porch, and there she and her family slept. She slept on the end of the porch next to the lot and Edward, an older son, on the other end so that they might hear if Indians came to bother the horses. After Old Placido quit staying with Grandfather, he came back to San Marcos regularly ${ }^{3}$. My mother has told me often how he used to want to hold me when I was a baby and how frightened she was for him to touch me." Grandmother leaned back in her chair, and drew a deep breath. "Well, we got away from our talk about how things were during the war, didn't we?" She seemed to be lost in thought, trying to remember just what we were talking about before Placido came into the story. I reminded her that she had been telling about spinning thread while staying with her Grandmother.

"Yes, she continued, "those were hard times. We had a hard time getting coffee. As a substitute, we used parched okra seed and some people used sweet potatoes. They cut the potatoes into small pieces, dried them, parched them and ground them up for coffee. I do not remember about other foods being scarce. There were men left in San Marcos to see that the families of the soldiers got provisions. My father's brother, Edward, was one who stayed. He used to tease us by saying that our daddy had to go 
and fight, but that he, Edward, did not. Edward did not mind having to fight, as far as that was concerned, for he fought in Indian battles. ${ }^{4}$

We were so happy to see our father when he came home from the war to stay. We moved back to our home west of San Marcos, but only for a short while, for Father was elected sheriff of Hays County and we came back to San Marcos. I might mention that our slaves, Oll and Jane, did not want to leave us when they were freed, and we hated to lose them, but Oll got some land to work not far from our place. They came to see us just as often as they could.

I do not remember very clearly anything that happened for a number of years, at least, not until I was grown. I went on a visit to Austin to see an aunt of mine. It was in 1874, I believe. The visit stood out in my mind because it was then that I saw my first railroad and train. At the dinner table, the first day I was there, my aunt told all the children and me that we would go down that afternoon to see the train. It was Austin's first railroad and had not been in use very long.5 We could not have been more excited had we been going to a circus. We went through the cars, and I thought I had never seen anything so wonderful. Suddenly, my aunt hurried us out of the train; she was afraid it would start and we would have to go clear to Manor before they would let us off.

Shortly after my visit to Austin, there occurred the last of the Indian hostilities around San Marcos, or at least, the last I remember hearing about. A Mr. and Mrs. Greenhaw were going from Gonzales to Blanco, and had stopped to spend the night with us in Purgatory Springs. They had their baby with them and their twelve year old boy. Mr. Greenhaw's people were expecting him and his family in Blanco, and when they failed to show up, some of his people came to see what had happened. They found the entire Greenhaw family where Indians had killed them, that is, all except the boy. He was carried off by the Indians, but finally did come back years later, after he was grown. Many people suspected a white man of being with and leading the Indians in this attack and in others before, but no one really knew."

To my questions about state and economic affairs, Grandmother replied that, after she married in 1875 , her time was occupied with the rearing of her family and she paid little attention to state affairs and economic conditions. Today, however, she is a close observer of the many events taking place around her. The radio is her constant companion, and she thoroughly enjoys the many conveniences she did without while growing up with Texas. 


\section{Endnotes}

${ }^{1}$ Wortham, L. J., A History of Texas, pp. 353-356.

${ }^{2}$ DeShields, J. T., Border Wars of Texas, pp. 290-297.

${ }^{3}$ Wilbarger, J. W., Indian Depredations in Texas, pp. 58-59.

${ }^{4}$ Brown, J. H., History of Texas, pp. 359.

${ }^{5}$ Bancroft, H. H., History of Texas and North Mexican States, p. 572. 


\section{Bibliography}

Bancroft, H. H., History of Texas and North Mexican States, vol. 2, The History Co., San Francisco, 1889.

Brown, J. H., History of Texas, vol. 2, L. E. Daniell, Becktold \& Co., St. Louis, N. D.

DeShields, J. T., Border Wars of Texas, The Steck Co., Austin, Texas, 1935.

Wilbarger, J. W., Indian Depredations in Texas, The Steck Co., Austin, Texas, 1935.

Wortham, L. J., A History of Texas, vol. IV, Molyneaux Co., Fort Worth, 1924.

By Interview.

My entire source of information for my paper was obtained from my grandmother, Mrs. Sarah M. Owen. The books listed above were used solely for verification or as sources giving additional information concerning events mentioned. 
Appendix L

\section{Record of Deed Transactions for the Mill Tract}

\begin{tabular}{|c|c|c|}
\hline From: & Rafael Garza \& Maria Veramendi & Ref: A:10 \\
\hline To: & Nathaniel Lewis & \\
\hline On: & Dec. 22,1840 & \\
\hline For: & $\$ 500$ & \\
\hline Acres: & of 640 & \\
\hline From: & Nathaniel Lewis & Ref: A:169 \\
\hline To: & Gen. Edward Burleson & \\
\hline On: & Aug. 21, 1845 & \\
\hline For: & $\$ 1,000$ & \\
\hline Acres: & ${ }^{\circ}$ of 640 & \\
\hline From: & Estate of Burleson, Admin: Sarah \& Joseph B. & Ref: C:6 \\
\hline To: & Fielding L. Rector & \\
\hline On: & April 3, 1855 & \\
\hline For: & $\$ 5,100$ & \\
\hline Acres: & 40 & \\
\hline From: & Fielding L. Rector & Ref: D:560 \\
\hline To: & Thomas Mooney & \\
\hline On: & Feb. 12, 1866 & \\
\hline For: & $\$ 5,000$ & \\
\hline Acres: & 40 & \\
\hline From: & Thomas Mooney & Ref: F:466 \\
\hline To: & James A. Smith & \\
\hline On: & May 6,1870 & \\
\hline For: & $\$ 6,000$ & \\
\hline Acres: & ${ }^{\circ}$ interest of 40 acres & \\
\hline From: & Thomas Mooney & Ref: F:478 \\
\hline To: & Samuel L. Peguez & \\
\hline On: & May 6,1870 & \\
\hline For: & $\$ 3,000$ & \\
\hline Acres: & ${ }^{\circ}$ interest of 40 acres & \\
\hline
\end{tabular}


Appendix L. Record of Deed Transactions for the Mill Tract (continued)

\begin{tabular}{|c|c|c|}
\hline From: & James A. Smith & Ref: G:576 \\
\hline To: & Samuel L. Peguez & \\
\hline On: & March 5, 1872 & \\
\hline For: & $\$ 3,000$ & \\
\hline Acres: & ${ }^{\circ}$ interest of 40 acres & \\
\hline From: & Samuel L. Peguez & Ref: G:607 \\
\hline To: & Thomas Mooney \& Sons & \\
\hline On: & March 9, 1872 & \\
\hline For: & $\$ 3,000$ & \\
\hline Acres: & ${ }^{\circ}$ interest of 40 acres & \\
\hline From: & Thomas Mooney \& Sons & Ref: I:521 \\
\hline To: & Thomas R. Fourgurean & \\
\hline On: & April 27, 1875 & \\
\hline For: & $\$ 6,000$ & \\
\hline Acres: & ${ }^{\circ}$ interest of 40 acres & \\
\hline From: & Samuel L. Peguez & Ref: Q:341 \\
\hline To: & Thomas Code & \\
\hline On: & March 1, 1883 & \\
\hline For: & $\$ 6,000$ & \\
\hline Acres: & ${ }^{\circ}$ interest of 40 acres & \\
\hline From: & Code \& Fourgurean & Ref: S:252 \\
\hline To: & L. D. Jackson & \\
\hline On: & Oct. 25,1883 & \\
\hline For: & $\$ 300$ \& upgrade of the property & \\
\hline Acres: & lease of 6 acres & \\
\hline From: & Thomas Code & Ref: S:219 \\
\hline To: & Edward Code & \\
\hline On: & Feb. 1, 1884 & \\
\hline For: & $\$ 4,023$ & \\
\hline Acres: & interest of 40 acres & \\
\hline From: & Edward Cody & Ref: S:432 \\
\hline To: & Benjarman E. Ostram & \\
\hline On: & April 28, 1884 & \\
\hline For: & $\$ 3,500$ & \\
\hline Acres: & interest of 40 acres & \\
\hline
\end{tabular}


Appendix L. Record of Deed Transactions for the Mill Tract (continued)

Hays County

Deeds and Records

Deed Transaction

Reference

\begin{tabular}{|c|c|c|}
\hline From: & Thomas R. Fourgurean & Ref: S:410 \\
\hline To: & William Goodrich Jones & \\
\hline On: & April 29, 1884 & \\
\hline For: & $\$ 4,000$ & \\
\hline Acres: & interest of 40 acres & \\
\hline From: & Thomas R. Fourgurean & Ref: S:412 \\
\hline To: & Frank M. Ball & \\
\hline On: & April 29, 1884 & \\
\hline For: & $\$ 4,000$ & \\
\hline Acres: & interest of 40 acres & \\
\hline From: & Heirs of B. E. Ostrom & Ref: U:171 \\
\hline To: & Hiram Dewing & \\
\hline On: & March 22, 1886 & \\
\hline For: & $\$ 6,088.17$ owed from mortgage & \\
\hline Acres: & interest of 40 acres & \\
\hline From: & Hiram Dewing by att. Wood & Ref: W:493 \\
\hline To: & San Marcos Water Company & \\
\hline On: & Oct. 12,1888 & \\
\hline For: & $\$ 6,500$ & \\
\hline Acres: & interest of 40 acres & \\
\hline From: & Frank M. Ball & Ref: X:257 \\
\hline To: & Dr. John Cooke & \\
\hline On: & March 13, 1889 & \\
\hline For: & $\$ 3,250$ & \\
\hline Acres: & $\checkmark$ interest of 40 acres & \\
\hline From: & William Goodrich Jones & Ref: X:256 \\
\hline To: & Dr. John Cooke & \\
\hline On: & March 22, 1889 & \\
\hline For: & $\$ 7,250$ & \\
\hline Acres: & interest of 40 acres & \\
\hline From: & Dr. John Cooke & Ref: Y:302 \\
\hline To: & Ed J. L. Green & \\
\hline On: & June 1,1889 & \\
\hline For: & $\$ 15,000$ & \\
\hline Acres: & ${ }^{\circ}$ interest of 40 acres & \\
\hline
\end{tabular}


Appendix L. Record of Deed Transactions for the Mill Tract (continued)

\begin{tabular}{|c|c|c|}
\hline From: & Thomas Code & Ref: X:381 \\
\hline To: & Ed J. L. Green & \\
\hline On: & June 20, 1889 & \\
\hline For: & $\$ 6,300$ & \\
\hline Acres: & interest of 40 acres & \\
\hline From: & Ed J. L. Green & Ref: X:383 \\
\hline To: & San Marcos Water Co. & \\
\hline On: & June 21, 1889 & \\
\hline For: & $\$ 4,775$ & \\
\hline Acres: & $\int$ of $^{-}$interest of 40 acres & \\
\hline From: & Ed J. L. Green & Ref: 31:67 \\
\hline To: & Eugene Green & \\
\hline On: & Aug. 7, 1893 & \\
\hline For: & $\$ 4,000$ & \\
\hline Acres: & $2 / 16$ interest of 40 acres & \\
\hline From: & Eugene Green & Ref: $31: 326$ \\
\hline To: & Ed J. L. Green & \\
\hline On: & Nov. 6, 1893 & \\
\hline For: & $\$ 4,000$ & \\
\hline Acres: & $2 / 16$ interest of 40 acres & \\
\hline From: & Ed J. L. Green & Ref: $31: 519$ \\
\hline To: & San Marcos Electric Light \& Power Co. & \\
\hline On: & Nov. 6,1893 & \\
\hline For: & $\$ 30,000$ & \\
\hline Acres: & $9 / 16$ interest of 40 acres & \\
\hline From: & San Marcos Electric Light \& Power Co. & Ref: $34: 397$ \\
\hline To: & Ed J. L. Green & \\
\hline On: & Sept. 4,1895 & \\
\hline For: & $\$ 1.00 \&$ other valuable considerations & \\
\hline Acres: & $9 / 16$ interest of 40 acres & \\
\hline From: & San Marcos Water Co. & Ref: $35: 532$ \\
\hline To: & United States of America & \\
\hline On: & April 24, 1896 & \\
\hline For: & $\$ 2,500$ & \\
\hline Acres: & $\begin{array}{l}\text { Agreement: water supply for fish hatchery from Spring Lake; } \\
\text { new dam built by citizens committee raising the water level } 20 \\
\text { inches; U.S.A. having right of way through \& under Mill tract } \& \\
\text { to take fish; take lake flow above or through dam }\end{array}$ & \\
\hline
\end{tabular}


Appendix L. Record of Deed Transactions for the Mill Tract (continued)

\section{Hays County \\ Deed Transaction}

From: $\quad$ San Marcos Electric Light \& Power Co.

To:

On:

For:

Acres:

From: William Green

To: $\quad$ San Marcos Ice Co.

On: $\quad$ Sept. 21, 1903

For: $\quad$ lease of building for manufacturing of ice for 50 years

Acres: $\quad 2 / 3$ of 1 acre

From: $\quad$ Ed J. L. Green

To:

On:

For:

Acres:

From: $\quad$ San Marcos Electric Light \& Power Co. \& San Marcos Water Co.

To: $\quad$ San Marcos Utilities

On:

For: July 20, 1909

not applicable

Acres: all lands owned by both companies including the 340 acre Homestead tract and the 40 acre Mill tract

From: $\quad$ San Marcos Utilities

Ref: 90:173

To:

On:

For:

Acres:

From:

To:

On:

For:

Acres:
Texas Public Utilities Co.

July 17,1925

$\$ 69,300$

3.72 acres (buildings: electrical)

3.1 acres (2.4 from Mill tract \& 7/10 from Homestead tract, including dam)

San Marcos Utilities

A. B. Rogers

May 21, 1926

$\$ 21,466$

107.33 (the Homestead tract and only the acreage of the Mill tract)
Ref: $46: 189$

Ref: $46: 365$

Ref: 55:510

Ref: 91: 458
Deeds and Records

Reference 
Appendix L. Record of Deed Transactions for the Mill Tract (continued)

Hays County

Deeds and Records

Deed Transaction

Reference

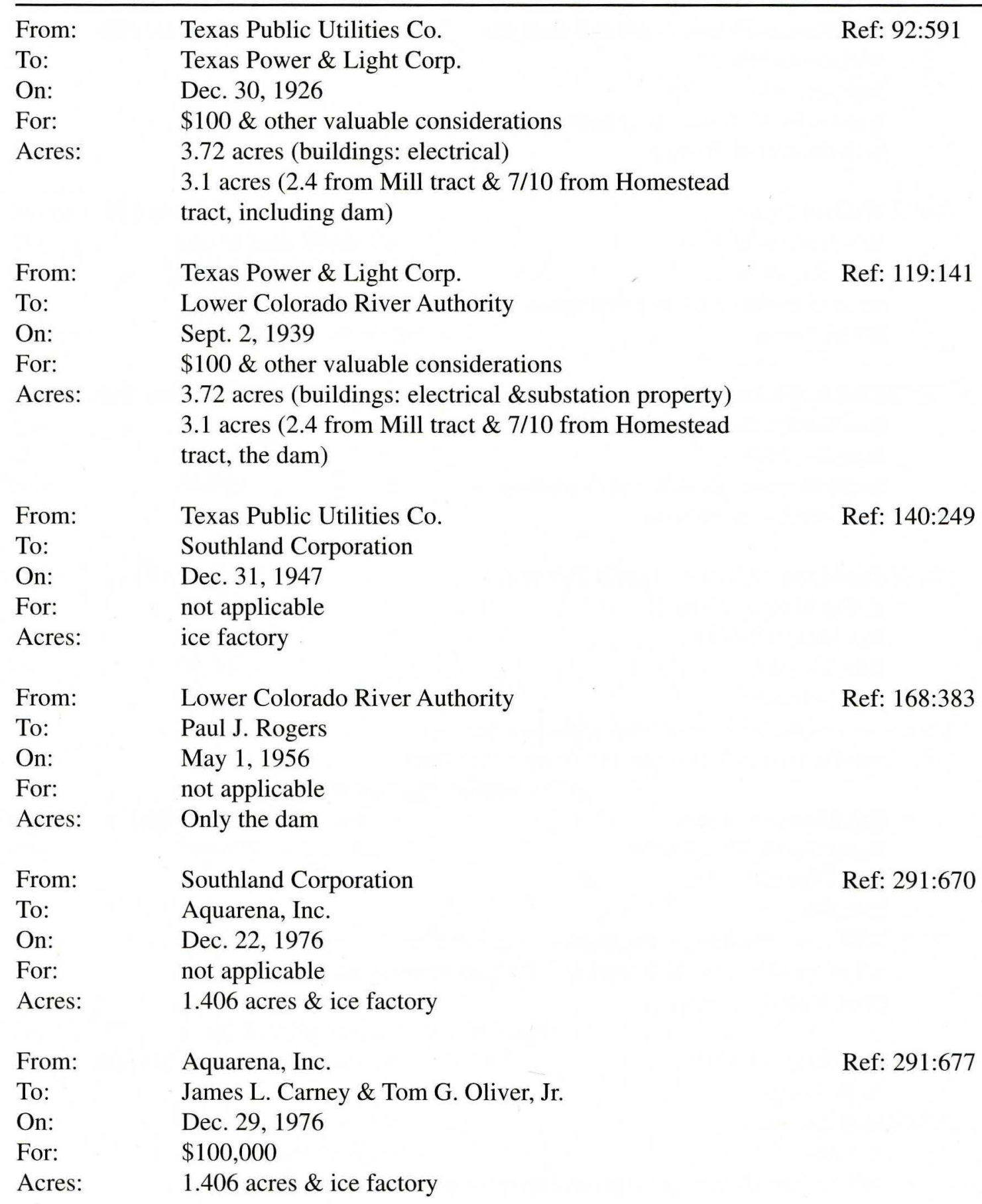


Appendix L. Record of Deed Transactions for the Mill Tract (continued)

Hays County

Deeds and Records

Deed Transaction Reference

From:

To:

On:

For:

Acres:

From:

To:

On:

For:

Acres:

From:

To:

On:

For:

Acres:
Tom G. Oliver, Jr. \& Richard Eugene Phillips

Baugh/Moore I Joint Venture

Sept. 5, 1985

$\$ 3,721,668.90$

Peppers, dam, Aquarena Springs

Baugh-Moore I Joint Venture

Southwest Texas State University

Jan. 24, 1994

not applicable

90.52

Southwest Texas State University

Joe's Crab Shack

Lease

Pepper's
Ref: 1046:546
Ref: 546:534

Ref: 1046:546 


\section{Record of Deed Transactions for the Old Burleson Homestead}

\begin{tabular}{|c|c|c|}
\hline From: & Rafael Garza \& Maria Veramendi & Ref: A: 10 \\
\hline To: & Nathaniel Lewis & \\
\hline On: & Dec. 22,1840 & \\
\hline For: & $\$ 500$ & \\
\hline Acres & $1 / 2$ of 640 & \\
\hline From: & Nathaniel Lewis & Ref: A:169 \\
\hline To: & Gen. Edward Burleson \& Dr. Eli T. Merriman & \\
\hline On: & Aug. 21, 1845 & \\
\hline For: & $\$ 1,000$ & \\
\hline Acres: & $1 / 2$ of 640 each & \\
\hline From: & Sarah Burleson (from will of Burleson) & Ref: C:454 \\
\hline To: & Cephas Thompson & \\
\hline On: & Oct. 19,1857 & \\
\hline For: & $\$ 3,500$ & \\
\hline Acres: & 340 & \\
\hline From: & Cephas Thompson & Ref: D:572 \\
\hline To: & L. M. McGehee & \\
\hline On: & May 1,1866 & \\
\hline For: & $\$ 3,500$ & \\
\hline Acres: & 340 & \\
\hline From: & Lucius McGehee \& Fannis McGehee & Ref: G:550 \\
\hline To: & Harvey North & \\
\hline On: & Feb. 7,1872 & \\
\hline For: & $\$ 4,500$ & \\
\hline Acres: & 340 & \\
\hline From: & Harvey North & Ref: K:498 \\
\hline To: & F. M. Noble & \\
\hline On: & Sept. 24,1877 & \\
\hline For: & $\$ 4,500$ & \\
\hline Acres: & 340 & \\
\hline From: & F. M. Noble & Ref: M:164 \\
\hline To: & E. S. Jennison & \\
\hline On: & May 17, 1879 & \\
\hline For: & $\$ 5,500$ & \\
\hline Acres: & 340 & \\
\hline From: & Louisa A. Jennison (from will of Jennison) & Ref: $39: 220$ \\
\hline To: & Edward J. L. Green & \\
\hline On: & May 1, 1900 & \\
\hline For: & $\$ 6,000$ & \\
\hline Acres: & 340 & \\
\hline
\end{tabular}


Appendix L. Record of Deed Transactions for the Old Burleson Homestead (continued)

From: $\quad$ Edward J. L. Green

Ref: 39:325

To:

San Marcos Water Company

Ref. 39.325

On: $\quad$ Aug. 7,1900

For: $\quad \$ 15,000$

Acres: $\quad 340$

From: $\quad$ San Marcos Electric Light \& Power Co.

Ref: 55:510

To:

On:

For: \& San Marcos Water Co.

Acres: all lands owned by both companies including the 340 acre Homestead tract \& the 40 acre Mill tract

From: $\quad$ San Marcos Utilities Company

Ref: 91:458

To:

A. B. Rogers

On: $\quad$ May 19,1926

For: $\quad \$ 21,466$

Acres $\quad 107.33$

From: $\quad$ A. B. Rogers \& Irene S. Rogers

Ref: $144: 330$

To: Paul J. Rogers

On: $\quad$ August 6, 1949

For: $\quad \$ 20,000$

Acres: $\quad 107.33$

From: $\quad$ Paul J. Rogers Trust

Ref: 546:534

To:

Baugh/Moore I Joint Venture

On: $\quad$ Sept. 5,1985

For: $\quad \$ 2,631,168.90$

Acres: $\quad 74.42$

From: $\quad$ Aquarena Springs Corp. \& May Springs Ltd.

To: $\quad$ Southwest Texas State University

Ref: 1046:546

On: $\quad$ January 24, 1994

For: $\quad$ Not Applicable

Acres: $\quad 90.52$ 


\section{Possessions of General Edward Burleson at Death}

(Source: Hays County Probate Records A:143-196)

1) 200 acres at San Marcos Springs, part of League No. 2, East of San Marcos. Granted originally to Juan M. Veremendi, lying northeast of San Marcos Springs.

Value: $\$ 2,000$.

2) 30 acres at San Marcos spring, part of League No. 1, Southwest of San Marcos. Granted originally to Juan M. Veramendi. Lying southwest of San Marcos Spring, the tract on which the mill and homestead and its appurtances are situated.

Value: $\$ 4,000$.

3) 1450 acres lying Northwest of the original grant of 2 leagues of land in the name of Juan M. Veramendi and adjoining and connecting with the Northeast of 2 league grant. Value: $\$ 4,350.507$ acres of land granted to the heirs of Henry Warnell (deceased) lying in Comal and Guadalupe limits about 7 miles southwest from San Marcos.

Value: transferred.

4) 220 acres in Bastrop County about 10 miles in an eastern direction from Bastrop. Granted to Edward Burleson as assigance of Joseph Garwood.

Value: $\$ 160$.

5) 320 acres in Bastrop county East of Colorado river about 10 miles East of town granted to James Burleson, Sr.

Value: $\$ 128$.

6) 1107 acres in Bastrop County West of Colorado river at 17 miles west from Bastrop. Granted to Henry Warnell.

Value: $\$ 554$.

7) 35 different lots in San Marcos and one whole block.

Value: \$558.

8) Farm lots and building lots 8 of them.

Value: $\$ 96.50$ 
9) Negro Slaves: Bob, Ol, American, Flora, Maria, Maria.

Value: $\$ 3,700$

10) Personal Property:

Horse called "Scurry" valued at nothing.

Horse called "Fontleroy" valued at $\$ 60$.

1 grey mare and colt valued at $\$ 75$.

1 Jack valued at $\$ 75$.

1 stud horse valued at $\$ 82.50$

60 head of cattle valued at $\$ 300$.

30 head of hogs valued at $\$ 60$.

60 head of goats valued at $\$ 60$.

1 yoke of oxen valued at $\$ 45$.

1 carry all vehicle valued at $\$ 60$.

11) Household and Kitchen furniture:

1 walnut wardrobe valued at $\$ 25$.

3 small trunks valued at $\$ 7$.

1 corner cupboard valued at $\$ 15$.

4 bad stands valued at $\$ 12$.

10 chairs valued at $\$ 5$.

4 feather beds valued at $\$ 60$.

12 feather pillows valued at $\$ 12$.

4 wool mattresses valued at $\$ 32$.

12 sheets \& 12 quilts valued at $\$ 18$.

12 bolster \& pillow covers valued at $\$ 6$.

2 stands of curtain for beds valued at $\$ 2$.

2 pair of window curtains valued at $\$ .50$

1 clock, 1 rifle gun valued at $\$ 4$.

1 shot gun valued at $\$ 8$.

lot of books valued at $\$ 5$.

1 book case valued at $\$ 5$.

2 tables valued at $\$ 6$.

1 writing desk valued at $\$ 2$.

Spie glass valued at nothing

dishes, knives, forks, and all the necessary apparatus in the dining room valued at $\$ 5$.

1 side saddle valued at $\$ 3$.

1 man's saddle \& bridle valued at nothing 
Appendix N. Possessions of General Edward Burleson at Death (continued)

12) 25 head of cattle in possession of Edward Burleson, Jr.

Value: $\$ 125$.

13) 25 head of cattle in possession of James C. and Mary Jane Stephenson, as well as feather bed and pillows \& side saddle.

Value: $\$ 153$.

14) 27 head of cattle possession of Felix \& Grace Kyle.

Value: 135.

General Edward Burleson had a net worth of $\$ 17,009.50$ 